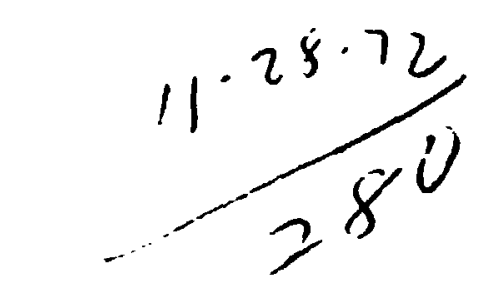

$$
\begin{array}{r}
1 C_{1} .23 \in 2 \\
\text { ORNL.4822 }
\end{array}
$$

INSTRUMENTATION

$$
\begin{gathered}
\text { AND } \\
\text { CONTROLS } \\
\text { DIVISION }
\end{gathered}
$$

ANNUAL REPORT - Period Ending Septemben 11972

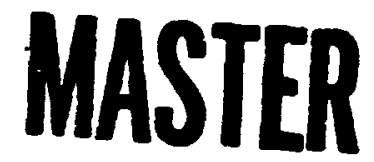

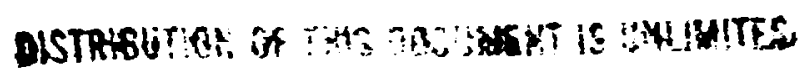


BLANK PAGE

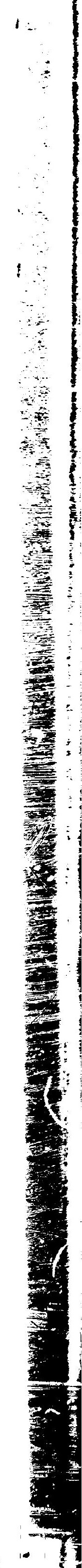



Printed in the United States of America. Available from
National Texhnical Information Service

US. Department of Commerce

5285 Port Royal Rosd, Springfield, Virginia 22151

Price: Printed Copy 53.00; Microtiche $\$ 0.95$

This report was prepared as an account of work sponsored by the United States Government. Neither the United States nor the United States A tomic Energy Commission. nor any of their emptovees, nor any of their contractors. subcontractors. or their employees, makes any warranty. express or implied, or scumes any legel lisbitity or responsibility for the sccuracy. completeness or usefulness of any informotion, apperatus, product of process dis sosed, or represents that its use rould not infringe privgteiv oumed rights. 


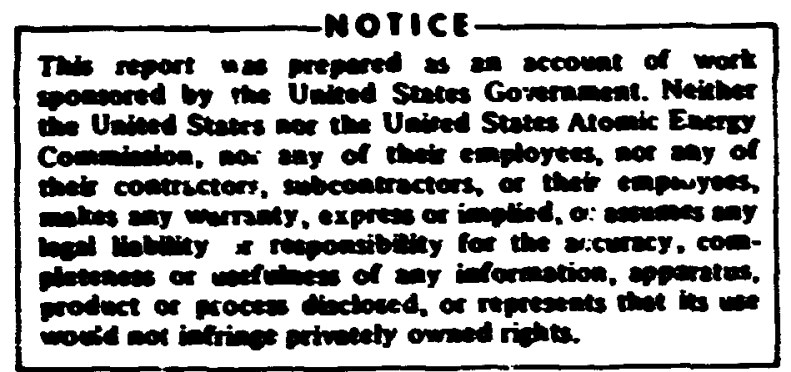

OANL AB:-

UC.37 - Hestor i. achnology UL-37 - liatri: nents

Contract No. W-7405ent 26

\author{
IUSTRUMENTATIOW AWD GONTROLS DIVISICN \\ ANNUAL PROGRESS REPORT \\ For Puriod Ending Sapuander 1, 1972 \\ C. J. Borkowski, Director \\ A. A. Dandl, Associate Director \\ L. C. Oakes, Aseociatt Dirsctor, and \\ Head, Reactor Contrc Dept.
}

Compilied and Edited by G.S. Sadomitri

From Raports by
R. K. Abele
R. L. Moore
C. J. Borkonski
C. A. Mosiman
J. W. Jotunson
L. C. Oakes
F. W. Menning
H. J. Stripling $d$.

\title{
OCTOBER 1972
}
OAK RIDGE NATIONAL LABORATORY OAk Rides. Tennesece 37830 opers. $\mathrm{j}$ by UNEON CARBIDE COAPOAATION for the U.S. ATOMIC ENERGY COMMISSION 
Reports previously issued in this series are as follows:

\begin{tabular}{|c|c|}
\hline & Period Fnding April 15, 1950 \\
\hline & Feriod Ending Juiy 15, 1950 \\
\hline RNL-9?4 & Period Ending October 31, 1950 \\
\hline RNL-1021 & Period Ending January 20, 1951 \\
\hline RNL-1056 & Period Ending April 20, 1951 \\
\hline RNL-1 159 & Period Ending July 20, 1951 \\
\hline RNL-1 ICO & Period Ending October 20, 1951 \\
\hline RNL-i335 & Feriod Encing January 20, i952 \\
\hline RNL-1336 & Period Ending April 20, 1952 \\
\hline ORNL-1 389 & Period Ending July 20, 1952 \\
\hline ORNL 1436 & Period Ending October 20 , \\
\hline ORN -1492 & Period Ending January 2 \\
\hline ORNL-1694 & Period Ending Jul \\
\hline ORNL-1749 & Period Ending Januan \\
\hline ORNL-1768 & Period Ending July 31, \\
\hline ORNL-1865 & Period Ending January \\
\hline ORNL-1997 & Period Ending Jisly 31 , \\
\hline ORNL-2067 & Period Ending January \\
\hline ORNL-2234 & Penod Ending July 31, i956 \\
\hline ORNL-2480 & Period Ending J \\
\hline ORNL-264 & Period Ending July I, 1958 \\
\hline ORNL-2787 & Period Ending July 1, 1959 \\
\hline ORNL-3001 & Period Ending July 1, 1960 \\
\hline ORNL-3191 & Feriod Ending July 1, 1961 \\
\hline ORNL-3378 & P-riod Ending September 1, 1962 \\
\hline URNL-3578 & Yeriod Ending September I, 1963 \\
\hline ORNL-3782 & Period Ending September 1, 1964 \\
\hline ORNL-3875 & Period Ending September 1, 1965 \\
\hline GRNL-4091 & Period Ending September 1, 1966 \\
\hline ORNL-4219 & Period Ending September 1, 1967 \\
\hline ORNL-4335 & Period Ending September 1, 1968 \\
\hline ORNL-4459 & Period Ending September 1,1969 \\
\hline ORNL-4620 & Period Ending September $1,197 \mathrm{C}$ \\
\hline ORNL -4734 & Period Ending September !, 1971 \\
\hline
\end{tabular}




\section{Foreword}

The role of the Instrumentation and Controls Division in the activities of the Laboratory is une of wide diversification and covers many lecimical disciplinies. A majout effort of the Division is to piovide professional service for the design. development, procurement, fabrication, installation, testing: and repair of many kirids of instruments. Another effort of the Division deals with instrumentation systems that protect or centrol complex processes such as chemical plants and nuclear reactors. which requires an understanding of the kinetic behavior of the processes during both normal and zonormal conditions. Thus. part of the woik of the Division is directed toward the analysis and evaluation of the dynamic behavior of large plants and facilities. It is only natural that the Division is participating in the preparation of standards and criteria for instrumentation systems for the control and protection of nuclear reactors.

The Division. which employed about 280 persons in fiscal vear 1972. comprises two departments and a small group: the Instrument Department, the Reactor Controls Department, and the Basic Instrumentation Group. This document is a report of the accomplishments and activities of these three groups.

It is our purpose in this report to tell what work we did - not how we did it. Since instument services ae provided for almost ali Laboratory divisions, we describe the scope of the work and its range of complexity from very simple components to complex. sophisticated systems. We hope that from this information our scientific readers at the Laboiatory will have a better understanding of the technological level and capability of this Division and perhaps will obtain some ideas on how some application described herein might be heneficially applied to other experimental work. Another purpose of this ieport is to announce new or improved designs of instruments, new methods of neasurement, accessories, etc., which represent a lower cost or inproved performance over an existing unit or are noteworthy for some other reason. such as extending the range of application.

Most topics are reported briefly, only one or two paragraphs. If a report or a journal article has been published or submitted for publication or if a paper has been given or proposed, the abstract is included here. We hope that interested readers desiring more information on any topic will call or write any of the persons whose names are listea vitii each topic.

\section{NOTICE}

"Tention of companies that supply products or services of of brand rames is made in this report for information purposes only and does not inpiy endorsement by Oak Ridge National Laboratory or the U.S. Atomic Energy Cornnission. 


\section{Contents}

FOREWORD

\section{PULSE COUNTING AND ANALYSIS}

1.1 PROPORTIONAL COUNTER PHOTON CAMERA

C. J. Borkowski and M. K. Kopp

1.2 SOME APPLICATIONS OF FLYS EYE: AN IMAGINC COUNTER FOR THERMAL NEUTRONS

J. B. Davidson and A. L. Case

1.3 A BROADBAND CIJRRENT PREAMPLIFIER CONFIGURATION FOR OBTAINING HIGH RESOLUTION E:NERGY AND TIME INFORMATION FROM NUCLEAR RADIATION DETECTORS

J. K. Milleru, T. V. Blalock, and N. W. Hill

1.4 FAST TIMING FROM A FISSION IONIZATION CHAMBER

H. Rosler, J. K. Millard, and N. W. Hill

1.5 LOW INPUT IMPEDANCE, FAST CURRENT AMPLIFIER FOR MEASURING $\sigma_{\mathrm{f}}$ FOR ${ }^{249} \mathrm{Cf}$

C. E. Bemis, Ir. et al.

1.6 THIN ${ }^{6} \mathrm{Li}(n, \alpha)$ T TRANSMISSION FLUX MONITOR

R. L. Macklin, B. J. Allen, and N. W. Hill

1.7 A HIGH RESOLUTION SPECTROMETER SYSTEM WITH PARTICLE IDENTIFICATION FOR I- THROUGH 60-MeV HYDROGEN AND HELIUM PARTICLES

F. E. Bertrand et al. . . . . . . . . . . . . . . . . . . . . . . . . . . . . . .

I.8 GATING UNIT FOR NEUTRON MULTIPLICITY COUNTER F. M. Glass et al.

1.9 MULTIPARAMETER DATA ACQUISITION SYSTEM

R. W. Ingle and J. W. Reynolds

I.10 CLOCK AND READOUT CONTROL FOR FISH TAG EXPERIMEIYTS

F. W. Snodgrass

1.11 RIST TECHNICAL SERVICE UNIT NUCLEAR ELECTRONICS

J. M. Rochelle

\section{MISCELLANEOUS ELECTRONICS DEVELOPMENT}

2.1 HYBRID MICROCIRCUIT ACTIVITIES

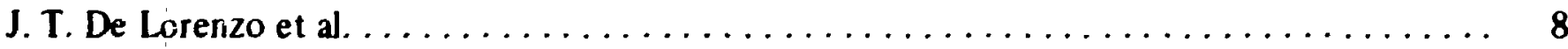

2.2 NIM SYSTEM POWER SUPPLY

E. E. Waugh et al.

2.3 IMPRO'ED NIM LAMINATED BUS

E. E. Waugh and G. A. Holt 
BLANK PAGE 
2.4 ELECTROCHEMIC AL AMBIENT AIR MONITOR

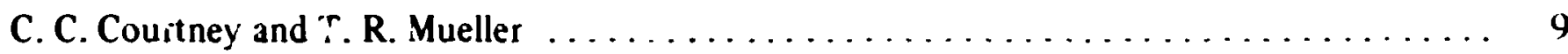

2.5 EMISSION-ABSORPTION PHOTOMETER

C. C. Courtney and I. R. Mueller ............................... 9

2.6 IONIZATION CHAMBER CURRENT QUANTIZER FOR RADIOLOGICAL

ENVIRONMENTAL MONITORING SYSTEM

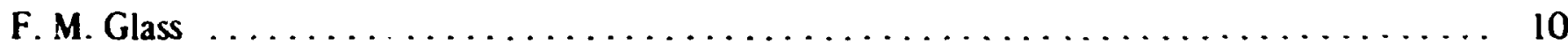

2.7 CRYSTAL CONTROLLED PULSE GENERATOR

F. M. Glass and C. C. Courtney ............................... 10

2.8 COMPACT CHARGE-SENSITIVE PREAMPLIFIER FOR ${ }^{3} \mathrm{He}$ COUNTER

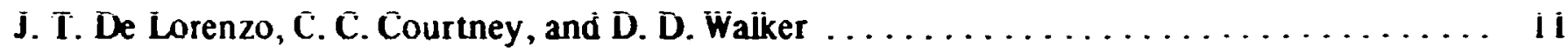

2.9 EVALUATION OF THE CD V-715-1 SURVEY METER AS AN EDUCATIONAL TOOL

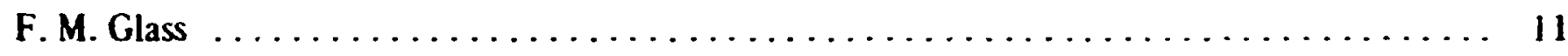

2.10 ULTRASONIC FISH TAG IMPROVEMENTS

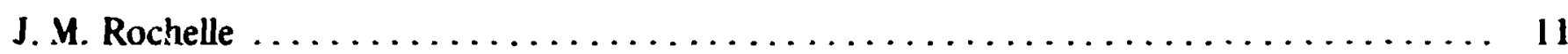

2.11 RADIATION DETECTOR CIRCUIT FOR AUTOMATED ATTACK-EFFECTS INFORMATION SYSTEMS-1

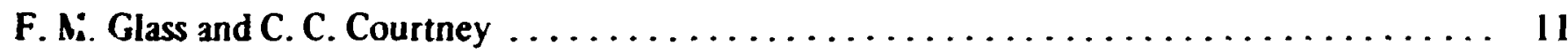

2.12 ENGINEERING STUDY OF A MODIFIED E-H ELECTROMETER MODEL 202

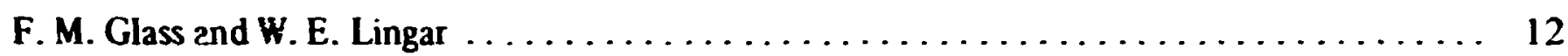

2.13 INVESTIGATION OF UNRELIABILITY OF MAGNET CURRENT SOJRCE

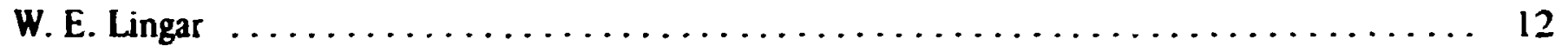

2.14 GROUND ISOLATION CARD TESTER

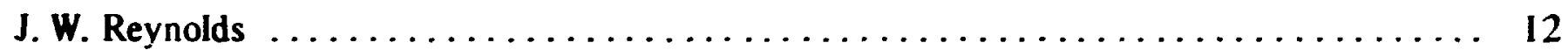

2.15 DATA ACQUISITION TESTER FOR THE ORELA

2.16 ZEBRA-STRIPE MICROWAVE INTERFEROMETER FOR ORMAK

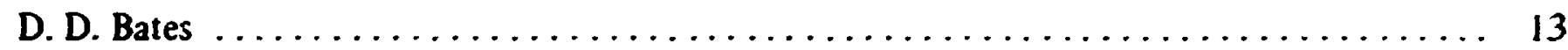

2.17 MICROWAVE PREIONIZATION GENERATOR FOR ORMAK

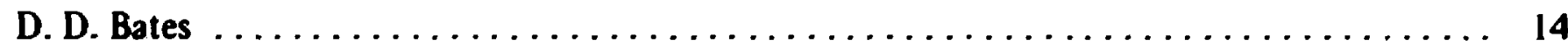

2.18 FAST IONIZATION GAGE FOR ORMAK

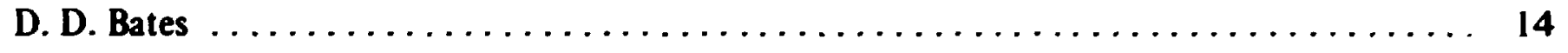

2.19 FAST ION GAGE REGULATOR

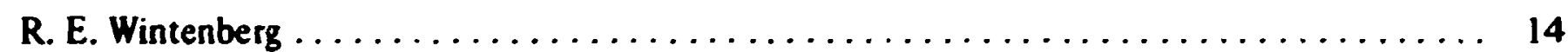

2.20 MINIATURIZED SELF-CONTAINED AMPLIFIER

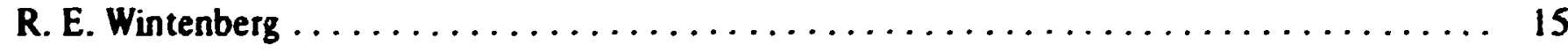

2.21 GROUND FAULT DETECTCR

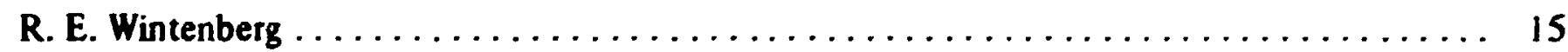

2.22 MEASUREMENTS OF THE SHIELDING EFFECTIVENESS OF COAXIAL AND TWO-CONDUCTOR CABLES

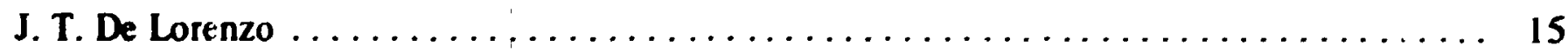

2.23 MEASUREMENT OF SHIELDING EFFECTIVENESS OF HIGH TEMPERATURE

COAXIAL CABLES

J. T. De Lorenzo et al. .................................... 16

2.24 BATTERY OPERATION OF INSTRUMENTS FOR FIELD EXPERIMENTS

J. M. Rochelle ........................................ 16 
2.25 INSTRUSIENT FABRICATION

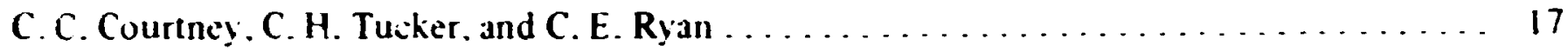

2.26 APPROVED WIRING DEVICES

G. A. Holt and $\mathrm{H}$. N Wilson

\section{DETECTORS OF IONIZING PARTICLES AND RADIATION}

3.1 MULTIWIRE PROPORTIONAL COUNTERS

H. K. Brashear, G. W. Allin, and H. O. Cohn .................. 18

3.2 SUPPORT FOR NEUTRON CROSS-SECTION MEASUREMENTS

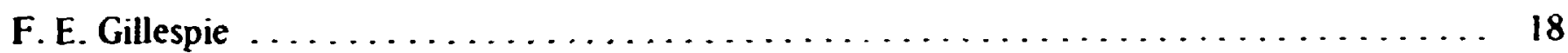

3.3 EXPERIMENTAL ELECTRONIC ACTIVITIFS

J. H. Todd and R. W. Ingle . ............................. 19

3.4 X-RAY DIFFRACTOMETER BEAM MONTOR IONIZATION CHAMBER

R. E. Zedler . . . . . . . . . . . . . . . . . . . . . . . . . . . . 19

3.5 VARIABLE ELECTRODE SPACING ${ }^{252} \mathrm{CI}$ FISSION CHAMPCR

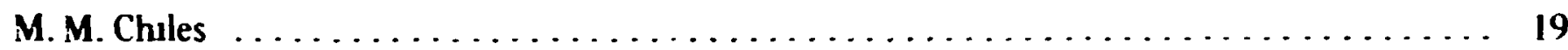

3.6 METHOD FOR REMOVAL OF WATER VAPOR AND OXYGEN FROM PROPORTIONAL COUNTER GAS

R. E. Zedler . . . . . . . . . . .

3.7 LGW-LEVEL DETECTOR FOR ALPHA CONTAMINATION MONITOR IN CONTINUOUSLY FLOWING PROCESS WASTE WATER

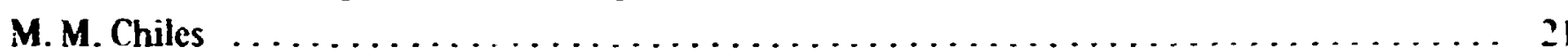

3.8 STATUS OF APOLLO SPACE PROGRAM SUPPORT

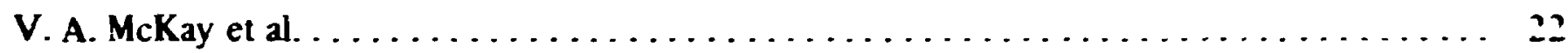

\section{RADIATION MONITORING}

4.1 RADIATION MONITORING SYSTEMS DEVELOPMENT

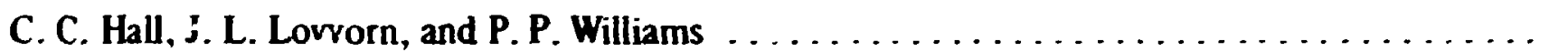

4.2 LOGARITHMIC COUNT-RATE METER

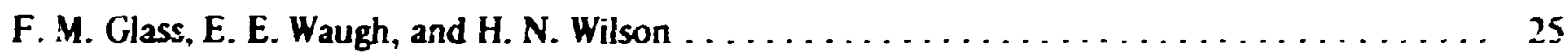

4.3 DIRECTIONAL GAMMA PROBE

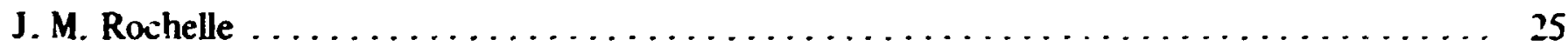

4.4 ADV ANCED AERIAL RADIAC STUDY

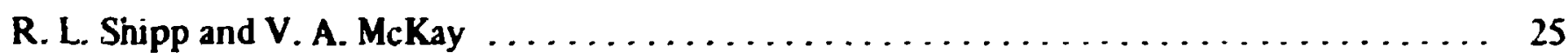

4.5 ENCINEERINC ANALYSIS OF THE CD Y-71I SHELTER MONITOR

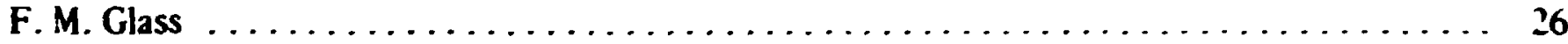

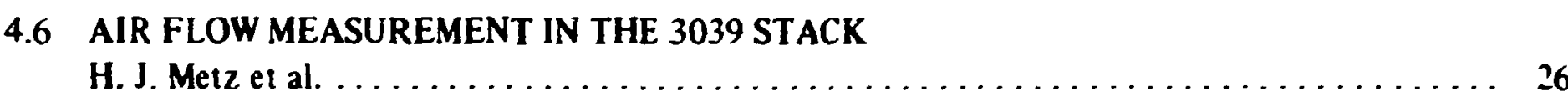

4.7 IODINE MONITOR IMPROVEMENTS

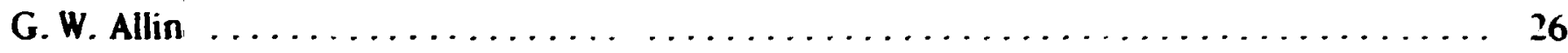

5. SUPPORT FOR THE OAK RIDGE ELECTRON LINEAR ACCELERATOR DEVELOPMENT

5.1 IMPROVEMENT PROGRAMS

T. A. Lewis . . . . . . . . . . . . . . . . . . . . . . . . . . . . . . . 27

5.2 ELECTRON INJECTION SYSTEM IMPROVEMENTS

J.' H. Holladay e, al. 
vii:

5.3 ORELA ENGINEERING DEVELOPMENT SUPPORT

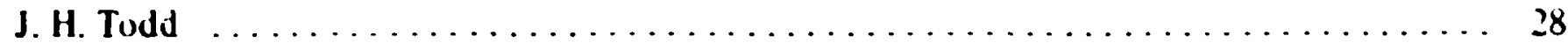

5.4 ELECTRONIC SERVICES FOR ORELA

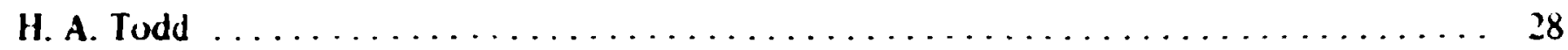

5.5 NEUTRON FILTER ASSEMBLY SYSTEM

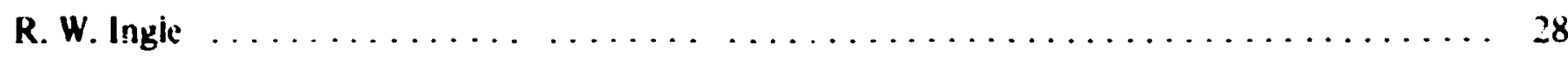

\section{AUTOMATIC CONTRGL AND DATA ACQUISITION}

6.I DATA ACQLISITION SYSTEM FOR THE FFTF TEMPERATURE SERSOR EVALUATION FACILITY

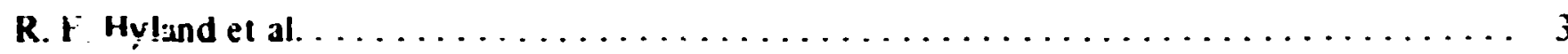

6.2 DATA ACQUISITION SYSTEM FOR THE FAILED-FUEL MOCKUP TESI FACILTY

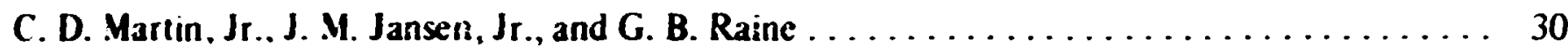

6.3 DATA ACQUISITION SYSTEM FOR HIGH TEMPERATURE THERMOMETRY LABORATORY

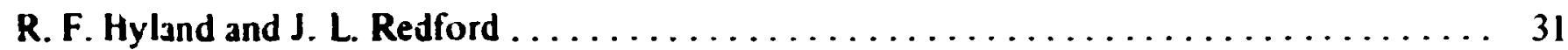

6.4 MINIATURE COMPUTER SYSTEM FOR THic GEMSAEC FAST ANALYZER

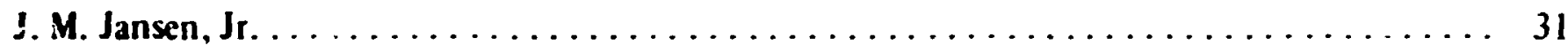

6.5 DATA ACQUISITION SYSTEM FOR TURF DEVELOPMENT LABORATORY

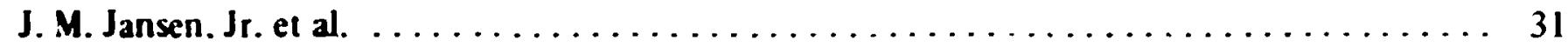

6.6 EXPERIENCE WITH DEXTIR DATA ACQUISITION SYSTEMS

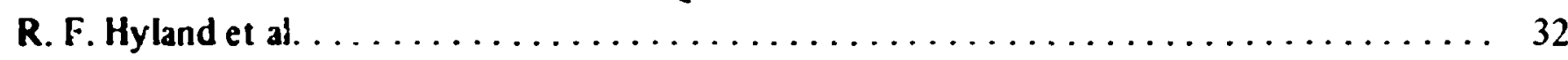

6.7 FOCAL COMPLIER PROGRAM FOR WIRE LIST GENERATION

AND MAINTENANCE

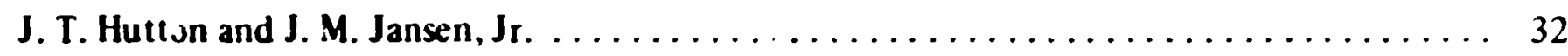

6.8 GENERALIZED HARDWARE-SOFTWARE INTER: ACE PACKAGE FOR INSTRUMENTS WITH BCD OUTPUTS

!. T. Hutton and J. M. Jansen, Jr. . . . . . . . . . . . . . . . . . . . . . 33

6.9 CONSOLIDATED PDP-8/E IN IERFACE FOR CONTROL OF SEVERAL

IIGH-PRECISION ANALOG INPUT SYSTEM COMPONENTS

¿. T. Hutton et al. . . . . . . . . . . . . . . . . . . . . . . . . . . . .

6.10 PAPER-TAPE PUNCH CONTROLLER FOR DIGITAL STRAIN INDICATOR SYSTEM

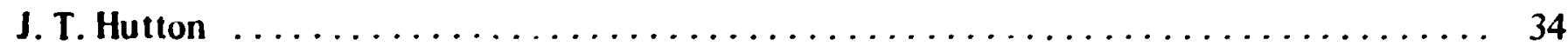

6.1 40-CHANNEL DATA LOGGER FOR THERMOCOUPLE CALIBRATION

J. T. Hutton and R. B. McFarland . . . . . . . . . . . . . . . . . . . . . . . 34

6.12 USAGE OF SMALLAOMPUIER APPLICATION DEVELOPMENT FACILITY

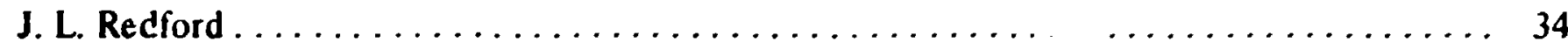

6.13 DEVICE HANDI.ER FOR MAGNETIC TAPE

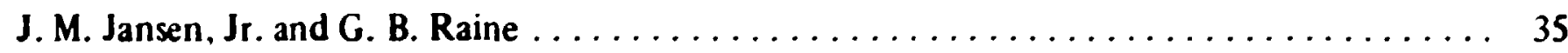

6.i4 STATUS OF WALKER BRANCH WATERSHED DATA ACQUISITION SYSTEM

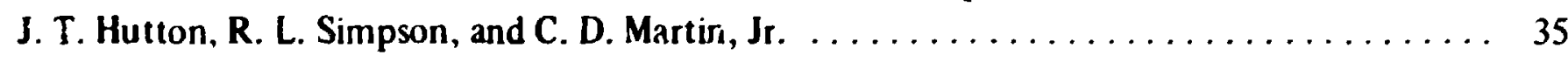

$6.15180^{\circ}$ ORSIS COMPUTER SYSTEM

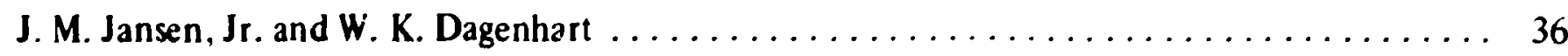


6.16 AUTOMATED ELECTROCARDIOGRAM DATA ACQUISITION SYSTEM

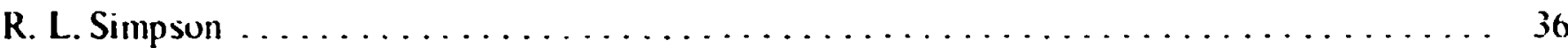

6.17 CODAS SYSTEM PROGRAMMING

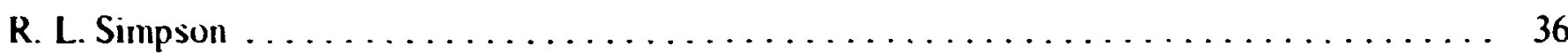

6.18 PROGRAMMING FOR STRESS LABORATORY DATA ACQUISITION SYSTEM

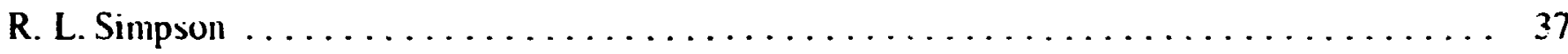

6.19 MULTISTAGE PROCESS COMPUTER CONTROL STUDIES SYSTEM PROGRAMMING

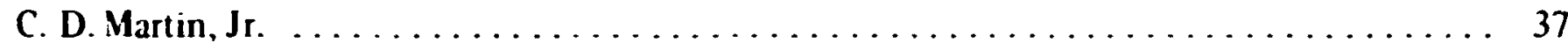

6.20 PORTABLE. STRAIN-GAGE-ORIENTED DATA ACQUISITION SYSTEM

C. D. Martin. Jr. . . . . . . . . . . . . . . . . . . . . . . . . . . . . 37

6.2! MISCELLANEOUS ECOLOGICAL F!ELD STUDIES

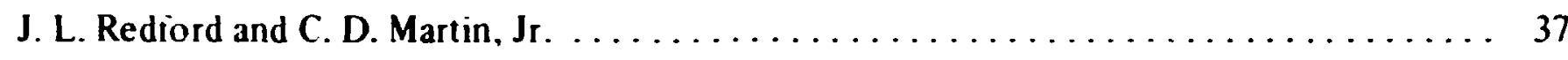

6.22 INTERACTIVE GRAPHICS PROGRAM FOR THE PDP IOAD4 HYBRID COMPUTER

S. M. Idell et al. . . . . . . . . . . . . . . . . . . . . . . . . . 38

6.23 APPLICATION OF ON-LINE COMPUTER DATA SYSTEMS TO EXPERIMENTAL

DESALiNATION PLANT ANALYSIS

S. J. Ball et al. . . . . . . . . . . . . . . . . . . . . . . . . . . . 38

6.24 :VUCLEAR DESALINATION PLANT CONTROL STUDIES

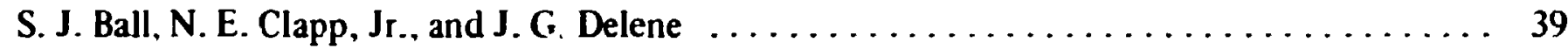

6.25 DATA ANALYSIS CRT DISPLAY COMMUNICATIONS

J. W. Reynolds, N. A. Betz, and R. E. Sellers . . . . . . . . . . . . . . . . . . . . 39

6.26 ST ATUS OF ORELA DATA HANDLING SYSTEM

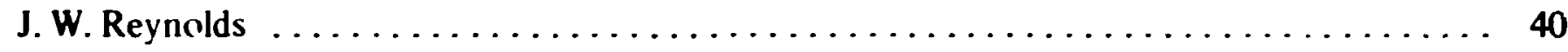

6.27 ORELA ISOLATED PULSE GENERATOR

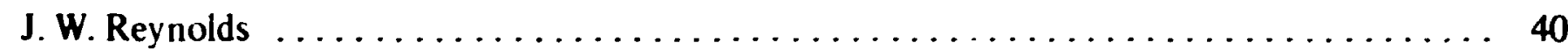

6.28 EIGHT-STAGE STACKING BUFFER MEMORY
R. E. Wintenberg and J. W. Reynolds $\ldots \ldots \ldots \ldots \ldots \ldots \ldots \ldots \ldots \ldots \ldots \ldots \ldots \ldots$

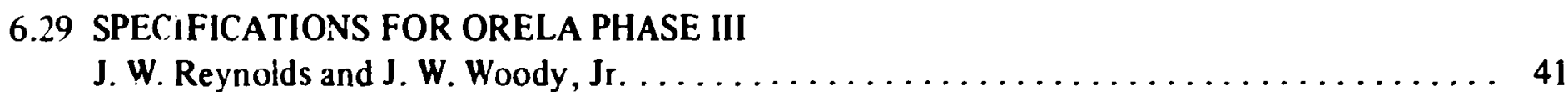

6.J0 ELECTRON SPECTROMETER

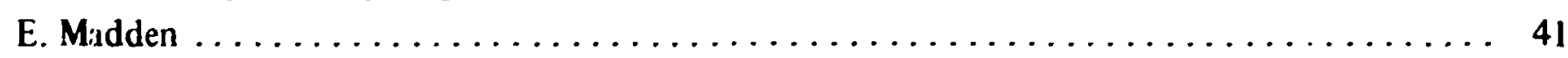

6.31 MODIFICATION OF VARIAN STATOS-III RECORDER
E. Madden $\ldots \ldots \ldots \ldots \ldots \ldots \ldots \ldots \ldots \ldots \ldots \ldots \ldots \ldots \ldots \ldots \ldots \ldots \ldots \ldots \ldots$

6.32 MODIFICATION OF A BENDIX SWEEP GAGE

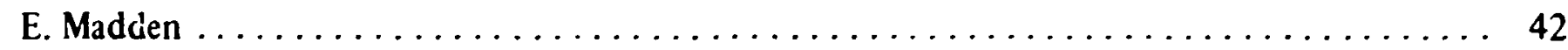

6.33 MODIFIED DEGREE MARKER

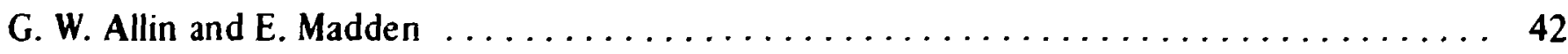

6.34 HB-3 DIFFRACTOMETER CONTROI, SYSTEM

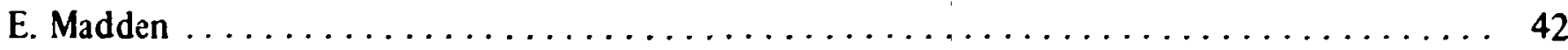

6.35 NEUTRON DIFFRACTOMETER CONTROL

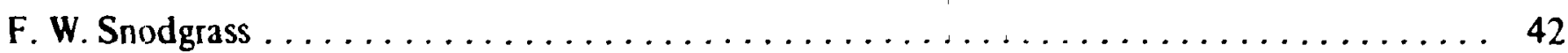

6.36 HB-4 TRIPLE-AXIS NEUTRON SPECTROMETER CONTROL SYSTEM
E. Madden $\ldots \ldots \ldots \ldots \ldots \ldots \ldots \ldots \ldots \ldots \ldots \ldots \ldots \ldots \ldots \ldots \ldots \ldots \ldots \ldots \ldots \ldots$

637 INCIDENT BEAM MONITOR AND CONTROL FOR A SMALL-ANGLE

$X$-RAY D! FFRACTOMETER

J. T. De Lorenzo et al. . . . . . . . . . . . . . . . . . . . . . . . . . . . . . 43 
6.38 ELECTRONIC CIRCUIT ANALYSIS PROGRAM (ECAP) WITH PLOTTING ROUTINE AND REVISED PRINTER OUTPUT FORMAT

J. T. De Lorenzo. C. W. Nestor, and C. C. Webster . . . . . . . . . . . . . . . . . 43

6.39 RADIOISOTOPIC SAND TRACER (RIST) STUDY FINAL REPORT

H. R. Brashear, E. H. Acree, and F. N. Case $\ldots \ldots \ldots \ldots \ldots \ldots \ldots \ldots \ldots \ldots \ldots \ldots \ldots \ldots \ldots$

6.40 COMPUTER SYSTEM FOR THE U.S. ARMY COASTAL ENGINEERING RESEARCH CENTER

J. M. Jansen, Jr. et al. . . . . . . . . . . . . . . . . . . . . . . . . . 44

6.41 CONTROL UNIT FOR A PORTABLE GAMMA SPECTROMETER

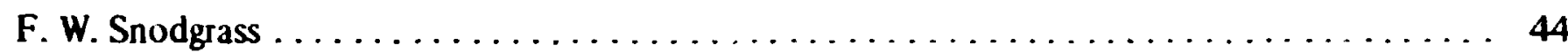

6.42 CASSETTE CONTROLLER

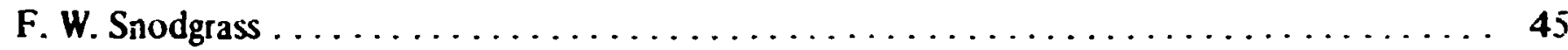

6.43 MOBILE FUEL-ASSAY VAN

E. McDaniei, V. A. McKay, and R. T. Roseberry .................... 45

6.44 COMPUTER-BASED MULTICHANNEL PULSE-HEIGHT ANALYZER AND

SAR:PLE CHANGER FOR ECOLOGICAL STUDIES

E. McDaniel, L. R. Gitgood, and R. T. Roseberry .................... 45

6.45 AUTOMATIC SAMPLE CHANGER

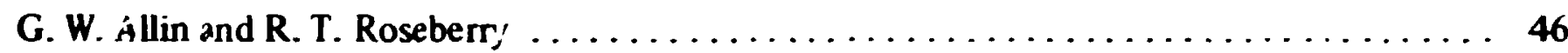

6.46 MASTER CLOCK-COMPUTER MARKER GENERATOR FOR ORMAK

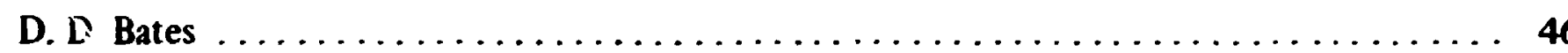

7. PROCESS INSTRUMENTATION AND CONTROL

SYSTEMS ENGINEERING

7.1 UPGRADING OF STEAM FLOWMETERS

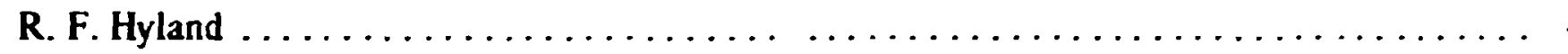

7.2 ELK RIVER DISMANTLING PROJECT

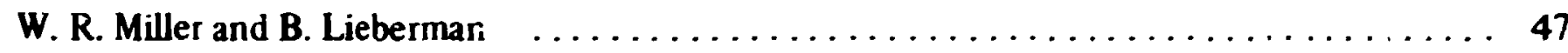

7.3 THERMAL TESTS ON A FOAMGLAS SHIPPING CONTAINER

H. E. Cochran and C. A. Mossmar .............................. 49

7.4 ANALYSIS OF ERRORS IN LINEAR VARIABLE RELUCTANCE TRANSEUCER

J. M. Googe . . . . . . . . . . . . . . . . . . . . . . . . . . . . . . 49

7.5 TRANSURANIUM PROCESSING PLANT

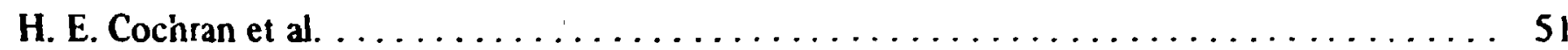

7.6 IMPROVED LIIQUID-WASTE TREATMENT AND STORAGE FriCILITIES

7.7 HTGR FUEL REFABRICATION DEVELOPMENT PROGRAM

H. E. Cochran and B. Lieberman ............................. 52

7.8 AQUATIC LABORATORY DESIGN STATUS
B. C. Duggins et al.

7.9 UPDATED INSTRUMENT ENGINEERING DRAWINGS AND DOCUMENTS

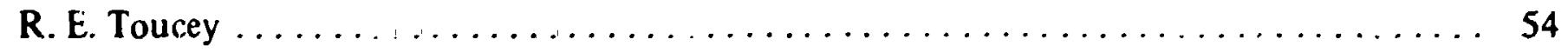

7.10 WATER QUALITY MONITORING

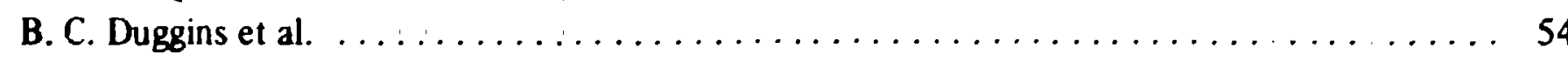


7.11 MODIFIED HELIUM LEAK DETECTOR FOR FIOW MEASUREMENT

it. L. Cuinrati. B. Lieberman, and C. B. Williams

7.12 PRESSURE SAFETY OF GLOVE BOXES

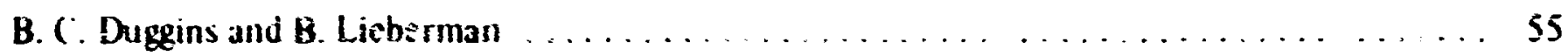

7.13 ROLX.TYPE DROP CALORIMETER

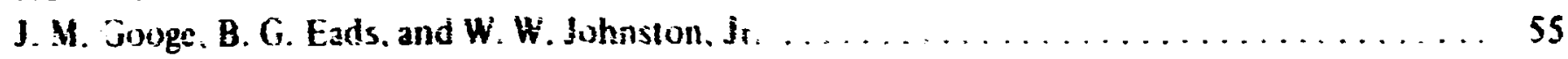

7.14 ENGINEERING SUPPORT FOR THE METALS AND CERAMICS DIVISION

B. G. Eads and J. T. Hutlon $\ldots \ldots \ldots \ldots \ldots \ldots \ldots \ldots \ldots \ldots \ldots \ldots \ldots \ldots \ldots$ Só

7.15 SPECIFICATIONS FOR ANNUNCIATORS AND FOR TEMPERATURE

SHUTDOWN DEVICES

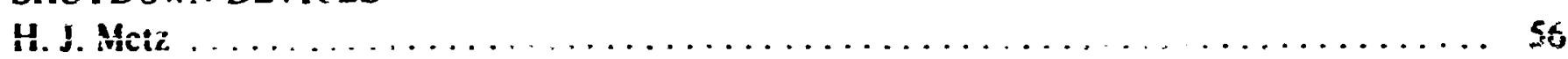

7.16 GAS CYLINDER STATION

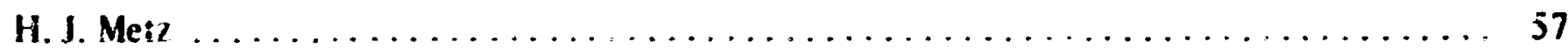

7.17 IMPROVED WIND TUNNEL

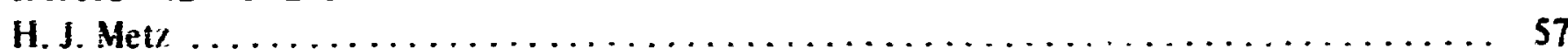

DEVELOPNENT INCLUOING BIOMEDICAL INSTRUMENTS

7.18 A MULTICUVET FAST FLUOROMETRIC ANALYZER BASED ON THE GEMSAEC PRINCIPLE

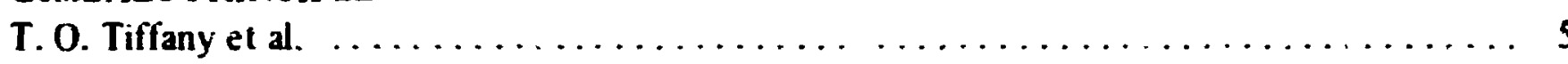

7.19 A RETROREFLECTIVE FIBER OPTIC TURBIDIMETER FOR CON TINUOUSLY MONITORING FERMENTATION

L. $H$. Thacker et al. . . . . . . . . . . .

7.20 DEVELOPMENT OF A MINIATURE FAST ANALYZER

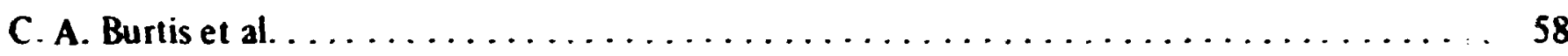

7.21 DEVELOPMENT OF A PORTABLE DATA PROCESSOR WITH MECHANICAL DATA OUTPUT FOR USE WITH A MINIATURE FAST ANALYZER

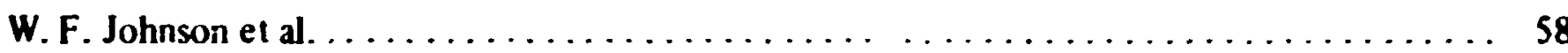

7.22 AUTOMATED SAMPLE-REAGENT LOADER FOR USE WITH THE GEMSAEC FAST ANALYZER

C. A. Burtis et al. . . . . . . . . . . . . . . . . . . . . . 59

7.23 A NEW SENSITIVE ULTRAVIOLET DETECTION SYSTEM FOR CARBOHYDRATES ELUTED DURING COLUMN CHROMATGGRAPHY

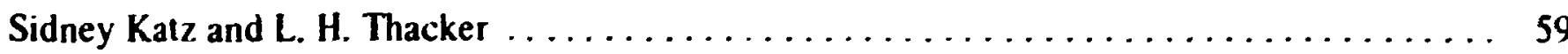

7.24 LASER OPTOELECTRONIC SYSTEM FOR PROJECTILE VELOCITY MEASUREMENT

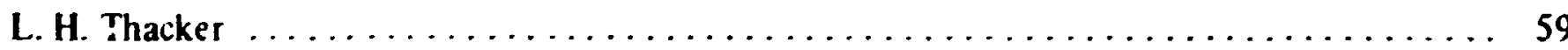

7.25 DEVELOPMENT OF SECONDGENERATION MINIATURE FAST ANAL IZER SYSTEM

W. F. Johnso I . . . . . . . . . . . . . . . . . . . . . . . . . . . . . . 60

7.26 A MINIATURE FLOW FLUOROMETER FOR LIQUID CHRUMATOGRAPHY

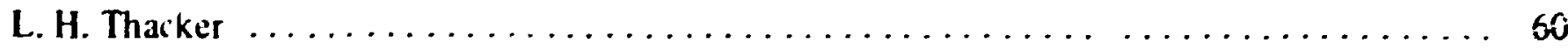

7.27 STANDARDS LABORATORY SERVICES

W. W. Johnston. Jr. et al. . . . . . . . . . . . . . . . . . . . . . . . . . . . . 60

THERMOMETRY PROGRAMS

7.28 NEW THERMOCOUPLE CHARACTERISTICS CONFORMING TO IPTS-1968

R. L. Simpson and R. K. Adams 
7.29 LMFBR IEMPERAIURE SENSOR DEVELOPMENT

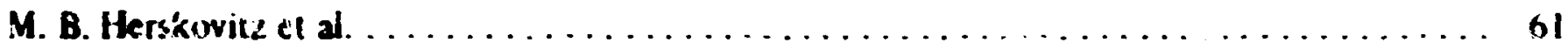

7.30 TESTING OF IRRADIATED CHROMEL-ALUMEL TIIERMOCOLPLES

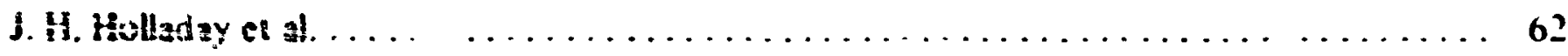

7.31 LARTE-SCALE PROCUREAENT OF TEMPERATURE SENSORS

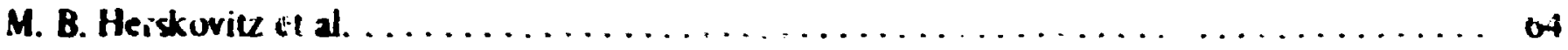

7.32 THERMAL SOAK OF THERMOCOUPLES

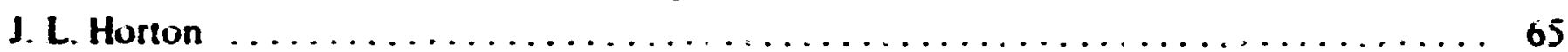

7.33 F.AILED FUEL. MOCKUP THERMOCOUPLES

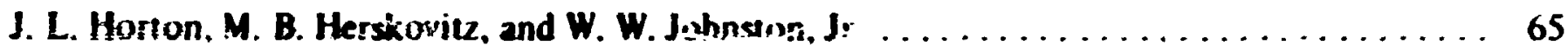

7.34 THERHOCRIDI E HSEULATION RESHSTANCE

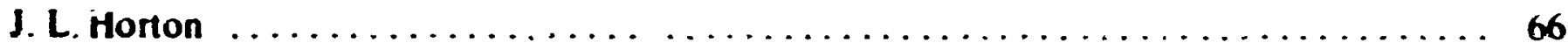

7.35 THERMOELECTRIC THERMAL-GRADIENT SENSOR

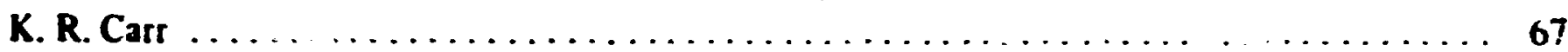

7.36 PLATINUM RESISTANCE THERMOMETERS

K. R. Cars et al. . . . . . . . . . . . . . . . 67

7.37 EXAMINATION OF THERMOCOUPLES IN SODIUM-HEATED STEAM GENERATOR

J. H. Holladay and M. B. Herskovitz $\ldots \ldots \ldots \ldots \ldots \ldots \ldots \ldots \ldots \ldots \ldots \ldots \ldots$

7.38 IN SITU THERMOCOUPLE TESTING

R. M. Carroll ................................... 69

7.39 TUNGSTEN-RHENIUM ALLOY EYALUATION FOR HIGH TEMPERATUPE

THERMOMETRY

R. i. Shepard and R. M. Carrol! .............................. 69

7.40 VELOCITY-OF-SOUND MEASUREMENTS IN SELF-HEATED WIRE

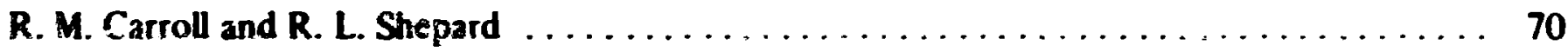

7.42 THERMOCOUPLE TESTING FIXTURES

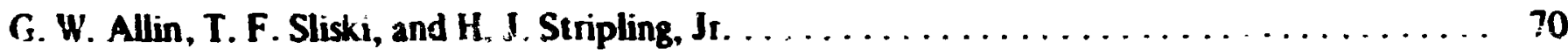

7.43 THEFMOCOUPLE SURVEILLANCE OF HRB-4 EXPEPIMENT

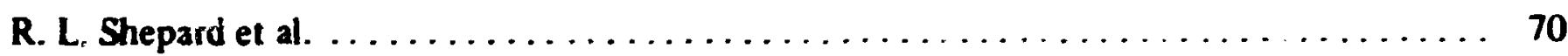

7.44 TESTS OF THERMOCOUPLES FOR THE HRB-4 EXPERIMFNT

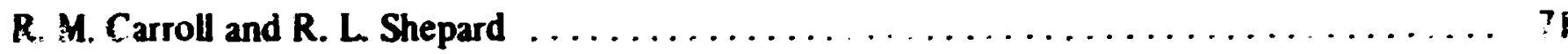

7.45 THERMOELECTRIC, RESISTANCE, AND ULTRASONIC CENTERLINE THERMOMETRY FOR A (U-PU, $\mathrm{O}_{2}$ FUEL PIN

R. L. Shepard et al. . . . . . . . .

7.46 A THREE-WIRE INSULATOR-SFIUNTING MODEL FOR HIGH-TEMPERATURE THERMOCOUPLE ERRORS

J. R. McDearman, J. K. Googe, and R. L. Shepard ..................... 73

QUALITY ASSURANCE

7.47 QUALITY ASSURANCE PLAN FOR THE LARGE-SCALE PROCUREMENT OF TEMPERATURE SENSORS

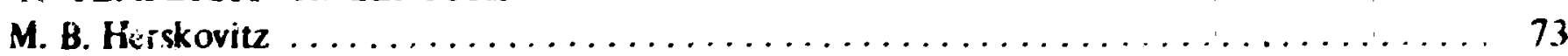

7.48 CODES AND STANDARDS FGR INSTRUMENTATION

C. S. Lisser and: A. Russell . . . . . . . . . . . . . . . . . . . . . . . . . . 73 
7.49 INSTRUMENTATIOP: QUAUTY ASSURANCE

C. S. Lisser et a!.

7.50 INSTRUMENTATION AND CONTROLS DIVISION DRAFTING AND DESIGN STANDARDS COMMITTEE

K. W. West et al.

\section{REACTOR INSTRUMENTATION AND CONTROLS}

\section{ANALYSIS}

8.I HYBRDD CGMPUTER S!MULATION OF THE MSBR

O. W. Burke. J. L. Anderson, and S. J. Ditto

8.2 AN INTERPRETATION OF 2.0 - $2.5 \%-\mathrm{MeV}$ NEUTRON PÜLSE PROPAGATION IN IRON

R. B. Perez et al.

8.3 BL.OWTHROUGH EXPERIMENTS ON THE OSW WRIGHTSVILLE BEACH 3-STAGE FLASH EVAPORATOR, AUGUST 1970

J. G. Delene, S. J. Ball, and N. E. Clapp, Jr.

\section{DEVELOPMENT}

\section{A. Fat Resctor Kinetics and Subcriticality Mesourement}

8.4 ON-LINE SUBCRITICALITY MEASUREMENTS IN SEFOR

A. R. Buhl et ai.

8.5 THE DETECTION EFFICIENCY DEPENDENCE OF SUBCRITICALITY MEASUREMENTS BY THE POLARITY SPECTRAL COHEREN.CE METHOD

N. J. Ackermann, Jr. and A. R. Buhl .

8.6 LOW-LEVEL NEUTRON FLUX MONITORING SYSTEM FOR LMFBR's

N. J. Ackermann, Jr. et al.

8.7 DEVELOPMENT AND DESIGN PROGRAM FOR FFTF SUBCRITICALITY AND STARTUP PHYSICS MEASUREMENT SYSTEM

N. J. Ackermann, Jr.

8.8 DEDICATED CRITICALFACILITY SUBCRITICALITY EXPERIMENT: EXPERIMENT PLANNING AND IN'STRUMENTATION SYSTEM DEVELOPMENT

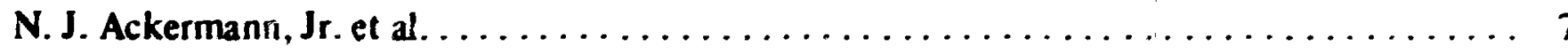

8.9 AUTOMATED INVERSE KINETICS ROD-DROP DATA ANALYSIS SYSTEM,

J. E. Mott, M. K. Churchich, and J. C. Robinson . . . . . . . . . . . . . . . . . . 80

8.10 COUNTING-LOSS EFFECT ON INVERSE KINETIC, ROD-DROP MEASUREMENT OF SUBCRITICALITY

J. C. Robinson, N. J. Ackermann, Jr., and J. W. Allen

8.1I AN INTERCOMPARISON OF TECHNIQUES FOR INFERRING SUBCRITICALITY IN FAST REACTORS

A. R. Buhl, J. C. Robinson, and N. J. Ackermann, Jr.

8.12 SUBCRITICALITY MEASUREMFNTS IN FTR-3: THE HOMOGENEOUS MOCKUP OF THE FAST TEST RE ICTOR

R. C. Kryter, N. J. Ackermann, Jr., and A. R. Buhl

8.13 VARIATION OF THE NEUTRON GENERATION TIME WITH SUBCRITICALITY IN THE FAST TEST REACTOR

A. R. Buhl and J. C. Robinsin 
8.14 TASK: A GENERALIZED ONE-DIMENSIONAL TRANSPORT AND DIFFUSIOה KINETICS CODE

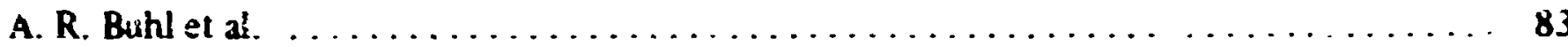

8.15 SUBCRITICALITY MEASUREMENT IN AN LMFBR

N. J. Ackermann. Jr.

B. Meutron Sensors for Extreme Environments

8.16 DEVELOPMENT OF A FISSION COUNTER FOR HIGH TEMPERATURE APPLICATION

W. T. Cla;j. D. P. Roux, G. C. Guerrant .

8.17 FISSIGN COUNTER TESTING PROGRAM

W. T. Clay, D. P. Roux, and B. J. Ball

8.18 FORMULATION OF THE GAMMA PILE-UP EFFECT IN FISSION COUNTERS

D. P. Roux and J. C. Robinson

C. Computer Control

8.19 COMPUTER SURVEILLANCE OF REACTIVITY DURING STARTUP AT THE HFIR

W. H. Sides, Jr., J. W. Allen, and J. B. Bullock ....................... 8

8.20 PROGRAM FOR THE FAST FOURIER TRANSFORM ON THE HYBRID COMPUTER

W. H. Sides, Jr.

8.21 QUALITY ASSURANCE TECHNIQUES FOR ON-LINE PROCESS COMPUTER

SOFTWARE

J. B. Bullock

8.22 REACTOR ON-IINE COMPUTER CONTROL DEVELOPMENT AT THE HFIR, VOL. I: OBJECTIVES, SYSTEM DESIGN, OPERATING

EXPERIENCE AND SAFETY CONSIDERATIONS

J. B. Bullock an 1 H. P. Danforth

8.23 REACTOR ON-LINE COMPUTER CONTROL DEVELOPMENT AT THE HFIR, VO:. 2: PRG'RRAM LISTINGS, SLMMARIES, AND LOGIC DIAGRAMS

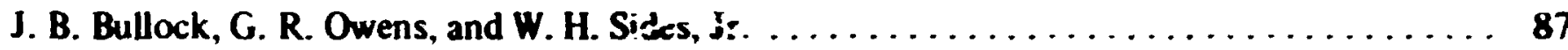

8.24 STUDY OF REACTIVITY BALANCE DURING STARTUP OF THE HFIR

J. W. Allen and $\mathbf{W}$. H. Sides, Jr. . . . . . . . . . . . . . . . . . . . . . . . . $\delta 8$

\section{Rexartor Diegnovis}

8.25 DYNAMIC EXPERIMENTS FOR HEAT TRANSFER AND FLOW MIXING STUDIES IN THE FUELFAILURE MOCKUP

T. W. Kerlin, D. N. Fry, and C. B. Stokes

8.26 ACOUSTIC MEASUREMENTS ON FFM

R. F. Saxe

8.27 DETECTION AND LOCATION OF FAILED FUEL IN THE FFTF BY DELAYED NEUTRONS

R. C. Kryter, D. P. Roux, and. A. R. Buhl

8.28 PRELIMINARY COOLANT TEMPERATURE OSCILLATION MEASUREMENTS AT THE FUEL-FAILURE MOCKUP

D. N. Fry and T. W. Kerlin 
8.29 NUCLEAR SATEIY INFORMATION CENTER

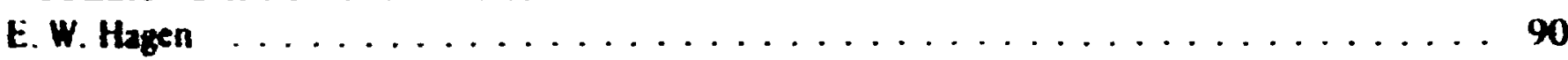

8.30 NUCI.EAR SAFETY JOURNAL

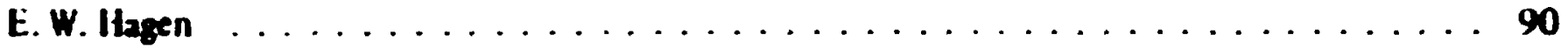

8.31 REACTOR AVAILABILTY AND STATION REUABIUTY FOR CONTINUITY OF SERVICE

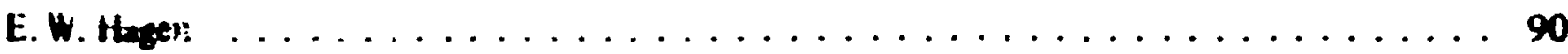

8.32 REU AÖLITY-ENGINEERING METHODS IN REACTOR-SAFETY TECHNOLOGY

Paul Rubel . . . . . . . . . . . . . . . . . . . . . 9l

8.33 THE FOURTEENTH POWER INSTRUMENTATION SYMPOSIUM OF THE INSTRUMENT SOCIETY OF AMERICA

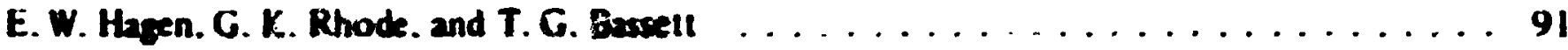

8.34 REPORT TOCONGRESS ON NUCLEAR REACTOR SAFETY

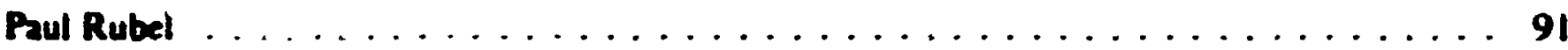

8.35 RELAABIUTY STUDIES OF PROPOSED UNDERSEA REACTOR

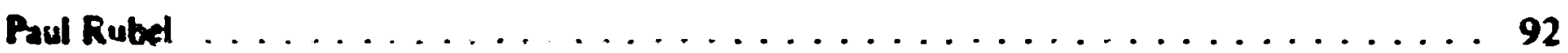

8.36 REUABULTY AND SAFETY ANALYSES OF HIGH-TEWTERATURE GAS-COOLED REACTOR SYSTEMS

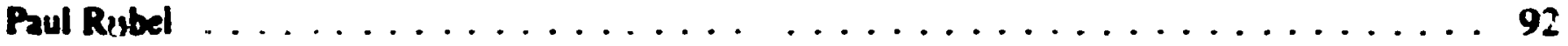

8.37 TASK GROUP FOR ECCS COMPM ITER CODES REVEW

R. S. Sione et a. . . . . . . . . . . . . . . . . . . . . . 92

8.38 HYBRD COMPUTATION OF FUELFIN HEAT-LP IN A PWR LOSS-OF-COOLANT ACCIDENT

R. S. Stone and F. H. Cbrk $\ldots \ldots \ldots \ldots \ldots \ldots \ldots \ldots \ldots$

8.39 RELAAIUTY METHODS AFPUED TO REACTOR SAFETY: TRENDS AND PROGRESS

Paul R.ibei $\ldots \ldots \ldots \ldots \ldots \ldots \ldots \ldots \ldots \ldots \ldots \ldots \ldots \ldots$

\section{REACTOR PRONECTS}

8.40 HFIR ASYMAETRY PROTECTION

W. E. Lingar. J. L. Anderson, and S. J. Dhito . . . . . . . . . . . . . . . . . . 94

841 REDUCTION OF ELECTRONC NOISE IN CURRENT PULLSE PREAMPLFIERS

J. T. De Lurcnes and D. P. Rnux . . . . . . . . . . . . . . . . . . . . . . . . 94

8.42 PBF CONTRUL AND SAFETY INSTRUMENTATION

J. L. Anderson et al. . . . . . . . . . . . . . . . . . . . . . . . . . . . 94

8.43 TSR-II MODIFICATIONS FOR I-AW OPERATIUN

S. J. Ditto et al. . . . . . . . . . . . . . . . . . . . . . . 95

8.44 MODERNIZATION OF PORTIONS OF THE HFIR PROTECTION AND CONTROL SYSTrius

J. L. Andersun and C. C. Courney $\ldots \ldots \ldots \ldots \ldots \ldots \ldots \ldots$ 9s

8.45 REVIEW OF STANDARDS AND DESIGN FOR FFTF PROTECTION SYSTEM

S. J. Ditto and J. L. Anderson . . . . . . . . . . . . . . . . . . . . 96

8.46 REVIFW OI: STATE.OF.THE-ART OF FAST SHUTDOWN SYSTEMS

E. P. Fpler. J. L. Anders nn, and S. J. Ditto . . . . . . . . . . . . . . 96 


\section{INSTRUMENTATION FOR REACTOR DIVISION EXPERIMENTS AND TEST LOOPS}

9.1 SUPPORT FOR THE SOLID-MECHANICS DEPARTMENT EXPERIMENTAL. MECHANICS SECTION

R. L. Moore et al. . . . . . . . . . . . . . . . . . . . . . . . . 97

9.2 THERMAL STRESS PIPING "T" TEST

G. W. Greene $\ldots \ldots \ldots \ldots \ldots \ldots \ldots \ldots \ldots \ldots \ldots \ldots \ldots$ 98

9.3 MISCELLANEOUS SUPPORT FOR THE ENGINEERING SCIENCE DEPARTMENT

HEAT TRANSFER AND FLUID MECHANICS SECTION

J. W. Krewson $\ldots \ldots \ldots \ldots \ldots \ldots \ldots \ldots \ldots \ldots \ldots \ldots$

9.4 HSTRUMENTATION FOR A ROD BURNOUT FACHLTY

R. L. Moore. D. G. Davis, and B. G. Eads . . . . . . . . . . . . . . . . . . . . . 99

9.5 THERMAL HYDRAULIC TEST FACILTY

R. L. Moore et al. . . . . . . . . . . . . . . . . . . . 99

9.6 FORCED CONVECTION DEPRESSURIZATION LOOP

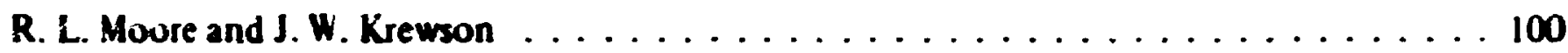

9.7 LMFBR THERMAL TRANSIENT TEST LOOP

C. W. Greene . . . . . . . . . . . . . . . . . . . . . 101

9.8 INSTRUMENTATION FOR LMFBR FUEL FAILURE MOCKUP FACIUTY

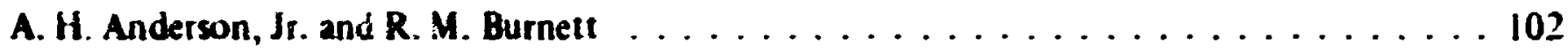

9.9 INSTRUMENTATION FOR MSBR COOLnitT SALT TECHNOLOGY FACILITY

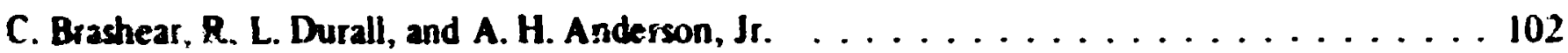

9.10 MOLTEN-SA! T BREEDER EXPERIMENT DESIGN

P. G. Herndon . . . . . . . . . . . . . . . . . . . . . . 102

9.11 INSTRUMENTATION FOR MSBR GAS SYSTEM TECHNOLOGY FAIILITY

P. G. Herndon . . . . . . . . . . . . . . . . . . . . . . . . . . . 102

9.12 MOLTEN-SALT FORCEDCIRCULATION LOOPS I AND 2

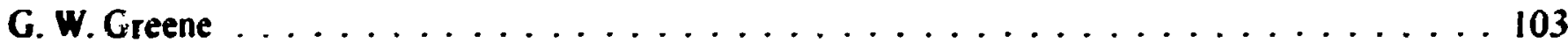

9.13 ORGANEC FLUID DECOMPOSITION LOOP

G. W. Greene . . . . . . . . . . . . . . . . . . . . . . . . . 103

9.14 AUTOMATIC WELDING SYSTEM

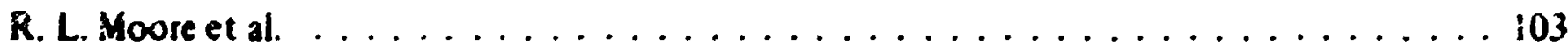

9.15 MSF/VTE HYBRID EVAPORATOR TEST MODULE INSTRUMENTATION

A. H. Malone . . . . . . . . . . . . . . . . . . . . . . . . . 104

10. MAINTENANCE AND SERVICE

10.1 ENGINEERINC AC TIVITIES OF THE SPECIAL ELECTRONIC

SERVICES GROU?

J. L. Lovvorn et al. . . . . . . . . . . . . . . . . . . . . . . . . . . . 105

10.2 MAINTEINANCE ACTIVITIES OF THE SPECIAL ELECTRONIC SERVICES SHOPS

J. L. Lovrorn and R. L. Mckinney . . . . . . . . . . . . . . . . . . . . . 105

10.3 MAINTENANCE AC IIVITIES FOR ENVIRONMENTAL SCIENCES AND SOLID

STATE DIVISIONS AND THE INSPECTION ENGINEERING DEPARTMENT

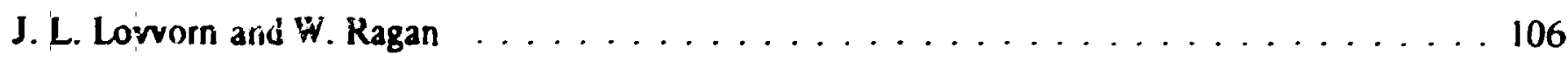

10.4 ACTIVITIES OF THE OAK RIDGE !SOCHRONOUS CYCLOTRON (ORIC)

INSTRUMFNT MAINTENANCE GROUP

J. L. Lowvorn and E. W. Sparks 
10.5 INSTABILITY OF A CYCLOTRON MAGNET SUPPLY

W. E. Lingar

11.6 ACTIVITIES OF THE RADIATION MONITORING SYSTEMS MAINTENANCE GROUP

J. D. Blantun, J. L. Lovvorn, and P. P. Willians

10.7 A? TIVITIES OF THE COMPUTER AND ANALYZER GROUP

E. M.Daniel and J. A. Keathley . . . . . . . . . . . . . . . . . . . 108

10.8 ACTIVITIES OF THE AUDIO-VISUAL SERVICE GROUP

C. C. Hall. J. L. Lovrorn, and J. Miniard . . . . . . . . . . . . . . . . . . 108

10.9 LABORATORY RADIO COMMUNICATIONS SYSTEM

J. A. Russell and D. J. Knuwles . . . . . . . . . . . . . . . . . . . IUS

10.10 CLOSEDCIRCUIT TELEVISION MONITORING SYSTEM

J. A. Russell and A. L. Case

10.1 I ACTIVITIES OF THE RADIO, TV, PAGING, AND INTERCOM MAINTENANCE GROUP

J. D. Blanton et al. 110

10.12 DESIGN ASSISTANCE TO REACTOR MAINTENANCE GROUP

J. L. Anderson and S. J. Ditto . . . . . . . . . . . . . . . . . . . . 110

10.13 MAINTENANCE OF THE BSR AND THE PCA

J. M. Farmer et al. . . . . . . . . . . . . . . . . . . . . III

10.14 MAINTENANCE OF REACTORS OPERATED BY THE NEUTRON PHYSICS DIVISION

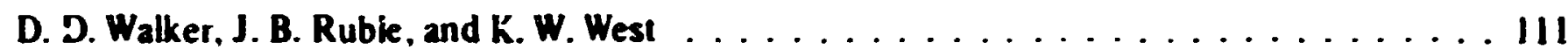

10.15 MAINTENANCE OF THE ORR

J. M. Farmer et al.

10.16 MAINTENANCE OF THE HFIR

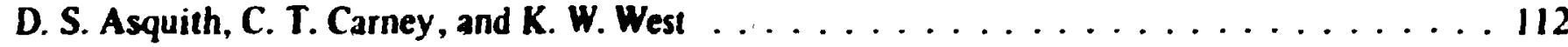

10.17 CURRENT LIMITER FOR DEFECT ETCHING MACHINE

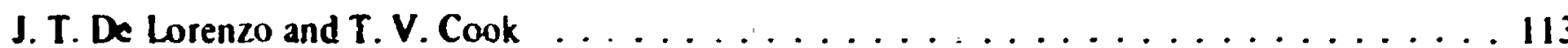

10.18 PURCHASE CONTRACT FOR DIFFERENTIAL, CURRENT-PULSE

PREAMPLIFIER

J. T. De Lorenzo

\section{ECOLOGICAL SCIENCES STUDIES}

11.! UNDERSTANDING THE DYNAMIC BEHAVIOR OF RADIONUCL!DES RELEASED TO THE ENVIRONMENT AND IMPLICATIONS

S. I. Auerbach et al.

11.2 MODELING THE ENVIRONMENTAL BEHAVIOR OF RADIONUCLIDES AND ESTIMATING DOSES TO MAN

M. J. Kelly et al.

11.3 APPLICATION OF ENVIRONMENTAL SYSTEMS ANALYSIS TO THE RADIOLOGICAL SAFETY ANALYSIS OF RELEASES TO THE ENVIRONMENT

E. G. Struxness et al.

11.4 RADIONUCLIDE TRANSFER TO MAN THROUGH AQUATIC PATHWAYS

R. S. Booth

11.5 DEVELOPMENT OF A GENERAL AQUATIC MODEL

R. B. O'Neill, R. S. Booth, and H. H. Shugart 
xviii

I!.o EXPERIMENTAL ANALYSIS OF A MESIC FOREST ECOSYSTEM

R. V. O'Neill et al. . . . . . . . . . . . . . . . . . . . . . 116

11.7 ANALYSIS OF THE FORAGE-COW-MODEL INCORPORATED INTO THE HERMES COMPUTER CODE

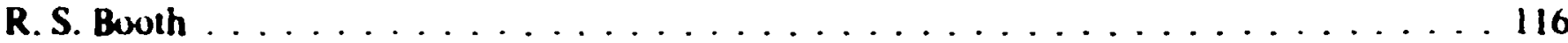

I1.8 A CUMULATIVE FXPOSURE INDEX (CUEX) FOR ASSESSING ENVIRONMENT AL RELEASES OF RADIOACTIVITY

S. V. Kaye et al.

$1 i .9$ A COMPENDIUM OF RADIONUCUDES FOUND IN UQUID EFFLUENTS

OF NUCLEAR POWER STATIONS

R. S. Routh e: al.

11.10 ENVIRONMENTAL IMPACI STATEMENTS

R. S. Booth

11.11 A SIMPLE SYSTEMS MODEL FOR DDT AND DDE MOVEMENT IN THE

HUMAN FOOD CHAIN

O. W. Burke and R. V. O'Neill $\ldots \ldots \ldots \ldots \ldots \ldots \ldots \ldots \ldots \ldots \ldots$

PROFESSIONAL AWARDS AND ACHIEVEMENTS AND OFFICES AND MEMBERSHIPS OF

PROFESSIONAL GROUPS HELD BY INSTRUMENTATION AND CONTROLS DIVISION

PERSONNEL $\ldots \ldots \ldots \ldots \ldots \ldots \ldots \ldots \ldots \ldots \ldots \ldots \ldots \ldots \ldots \ldots \ldots \ldots \ldots \ldots \ldots$

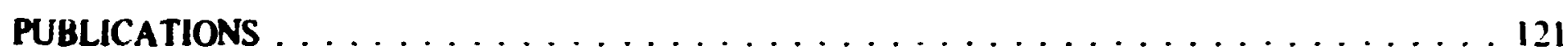

PAPERS PRESENTED AT PROFESSIONAL MEETINGS $\ldots \ldots \ldots \ldots \ldots \ldots \ldots \ldots \ldots$

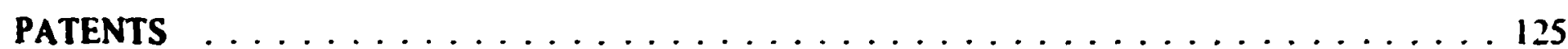

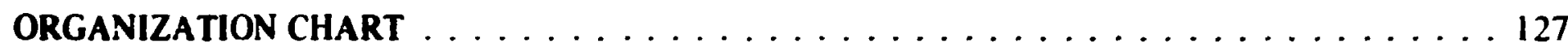




\title{
1. Pulse Counting and Analysis
}

\subsection{PROPORTIONAL COUNTER PHOTON CAMERA'}

\author{
C. J. Borkowski M. K. Kopp
}

A gas-filled proportional counter camera that images photon emitting sources was built and iested. This camera measures and displays the impact location of individual photons in an energy range between 1 and $150 \mathrm{keV}$ and permits pulse shape and energy discrimination for background reduction. Possible fields of applications for this camera incluoie nuclear medicine. nuclear physics. $x$-ray diffraction, and related areas. The signal processing of the camera is based on further improvements and simplifications of the risetime method as applied to multiwire position-sensitive counters. Materials inside the counter were selected so that the camera can be used over long periods of time without purification of the counter gas.

The sensitive area of the camera is $200 \times 200 \mathrm{~mm}^{2}$. and the size of each picture ekment is $1 \times 1 \mathrm{~mm}^{2}$ : thus 40,000 picture elements are resolved. Counting rates of up to 20.000 photons/sec do not appreciably affect the spatial resolution. The camera has been tested only with low energy photons ( $<30 \mathrm{keV})$ to determine the properties and applicability of the camera; however, by use of high nressure $(>10 \mathrm{~atm}) \mathrm{Xe}$ counter gas, a useful detection efficiency $(>30 \%)$ and good spatial resolution are expected for 150 -keV photons.

1. Abstract of published paper: IEEE Trans. Nucl. Sci NS-19 (3), 161 -68 (1972).

\subsection{SOME APPLICATIONS OF FLYS EYE: AN IMAGING COUNTER FOR THERMAL NEUTRONS}

\section{J. B. Davidson A. L. Case}

The position-sensing counter developed for thermal neutrons and reported in previous annual reports was tested as a low-level, digital radiographic camera. Tests were made using a standard image quality indicator and familiar objects, e.g., the ORNL film badge. Cadmium holes $0.5 \mathrm{~mm}$ in diameter and separated $0.25 \mathrm{~mm}$ were clearly seen. Color radiographs in which neutron transmission was translated to color were taken directly from the analyzer display screen. These included sierenscopic pairs. Using a promethium-147 source and the same lithium fluoride-zinc sulide screen as for neutrons. :-radiographs were also taken.

Through the conperation of the staff of the ORAU cancer hospital, a section of bone known to contain a tunior was obtained to explore an application to cancer detection as descritad by Whittenore and Boyne, ${ }^{1}$ among others. Figure 1.2.1 shows an ordinary $x$-ray photograph above and the neutron radiograph below.

Tissue from the small end of the bone section was examined and found cancerous. although the $x$-ray and visu $I$ inspections were inconclusive. The large dark area on the left was previously known to be 
cance-ous. The exposure to the bonc was approxinately $1 \mathrm{mR}$. Further tests with other specimens and with confirmatory histology are pianried.

The detector was applied to nondestructive examination of ferrite erystals which had been grown in platinum crucibles. Bragg reflections from the erystals were displayed on the monitor and recorded in the an alyzer bifore the erucibles were upered. When the crystals were poorly formed, the material was melted and regrown at a considerable saving. Previous inspection techniques using Laue patterns recorded on film had been difficult to interpret and had required several hours instead several inutes required with Fly's

PHOTO 3347 - 72
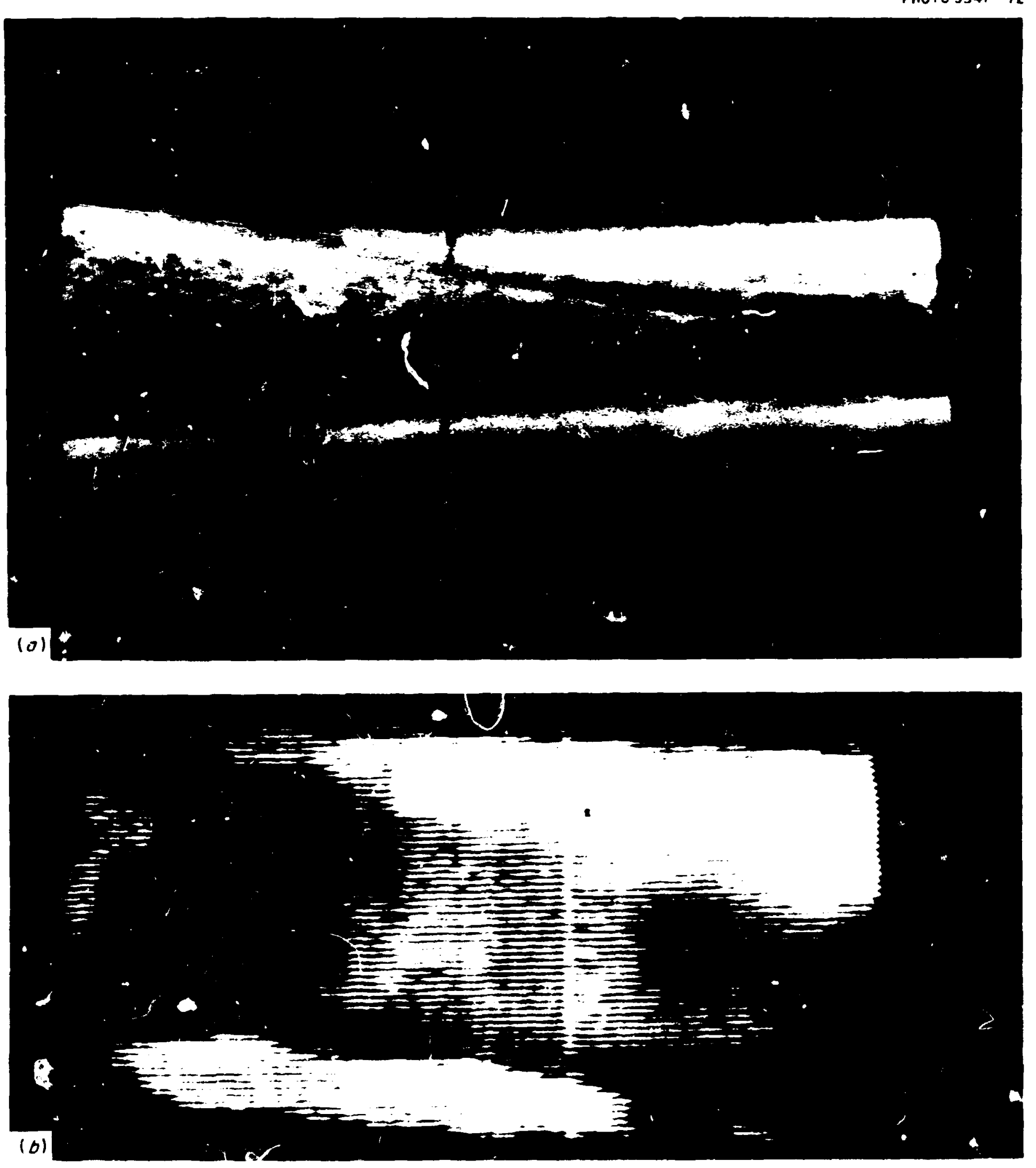

Fig. 1.2.1. Comparison of an ordinary $x$-ray and a neutron radiograph of a diseased bone take with Fly's Eye. (a) X-ray and $(b)$ neutron radiograph. 
Eye. The reflecting power of the various planes was clearly seen and suggested an important application in neutron diffraction topography: ${ }^{2}$

A promising area of application appears to be the study of oriented tibe's by neutron diffraction. A diffraction pattem from a small sample of Teflon $(3 \times 4 \mathrm{~mm})$ clearly showed order in the structure. The ares of the gattern were just visible on the live TV r'onitor. A run of $30 \mathrm{~min}$ gave a well-defined pattem on the displays of the $20 \mathrm{~K}$ channel $(200 \times 100)$ anaiyzer.

Work to improve the spatial resolution or the systen is being continued. The horizontal resolution. with a $0.5 \mathrm{~mm}$ phosphor thickness, is $0.12 \mathrm{~mm}$ fwhm. The vertical resolution is $1 \mathrm{~mm}$ ishm.

A patent application was filed by the U.S. Atomic Energy Commission for this method of improving the vertical resolution of a TV based pisition-sinsing detector. We have nijt beeî sble to incorporate this method into the system because of lack oi funding.

1. P. J. Boyne and W. L. Whittemore, Nature 30, 461-2 (April 16, 1971).

2. K. Doi et a!., J. Applied Cryst. 4, 528 (1971).

\subsection{A BROADBAND CURRENT PREAMPLIFIE \& CONFIGURATION FOR OBTAINING HIGH RESOLUTION ENERGY AND TIME INFORMATION FROM NUCLEAR RADIATION DETECTORS'}

\section{$\begin{array}{lll}\text { J. K. Millard } & \text { T. V. Blalock } & \text { N. W. Hill }\end{array}$}

A broadband current preamplifier was developed to complement nuclear spectrescopy systems requiring linear gating. The preamplifier stage configuration consists of an FET input, a broadband interstage current gain section, and a high-impedance feedback network. The preamplifier produces a noise line width comparable to charge-sensitive designs having similar parameters. Because of large handwidths and low-noise performance, the preamplifier, sonnected direct'. to a fast leadingedge discriminator, generates very accurate timing data.

A preamplifier consisting of three gain stages was built and subsequently tested with $\mathrm{Ce}(\mathrm{Li})$ detectors. This preamplifier had a current gain of 10,000 , a rise time of $8 \mathrm{n}^{\circ} \cdot \mathrm{c}$ with a 10-pF detector capacitance, and a 0-pF noise line width, using an RC-RC ungated filter, of $1.4 \mathrm{keV}$ (fw'lm $\mathrm{Ge}$ ). With the preamplifier operating from a $10 \mathrm{cc} \mathrm{Ge}(\mathrm{Li})$ coaxial detector, timing experiments utilizing the ${ }^{60} \mathrm{Co}$ gamma cascade indicated resolutions as low as $1.15 \mathrm{nsec}$ fwhm.

1. Abstract of paper published in IEEE Trans. Nucl. Sci. NS-19(1), 388-95 (February 1972).

2. Present address: Hewlett-Packard Co., Colorado Springs, Colo.

3. Consultant frn:-. the University of Tennessee, Knoxiville, Electrical Engineering Department.

\subsection{FAST TIMING FROM A FISSION IONIZATION CHAMBER'}

$$
\begin{array}{lll}
\text { H. Rosler } & \text { J. K. Millard } & \text { N. W. Hill }
\end{array}
$$

The timing resolution of a ${ }^{252} \mathrm{Cf}$-loaded fission ionization chamber connected to a new current preamplifier has been tested by looking at coincident fission fragment pulses and pulses from fission $\gamma$-rays which are detected in a plastic scintillator. A time resolution of 1 nsec fwhm could be achieved.

1. Abstract of paper published in Nucl. Instr. Methods 99(3), 477-8; (March 15, 1972 ).

2. Visiting scientist from Reaktorstation Garching, Munchen, Germany.

3. Present address: Hewlett-Packard Company, Colorado Springs, Colo. 


\title{
1.5 LOW INPUT IMPEDANCE. FAST CURRENT AMPLIFIER TOR MEASURING $\sigma_{\mathrm{f}}$ FOR ${ }^{2+9} \mathrm{CF}$ \\ C. E. Bemis, Jr.'

$\begin{array}{ll}\text { J.W. T. Dabbs } & \text { A. N. Ellis } \\ \text { N.W. Hill } & \text { M. S. Moore }\end{array}$

To determine fission cross sections from time-of-flight measurements for short-lived, transurani. elenents such as ${ }^{249} \mathrm{Cf}$, the alpha particle pile-up count rate must be reduced to a small percentage of the neutron-beam-induced fission rate. This requires small samples, intense neutron beams, and fast current collection times for the alpha events.

A technique that meets these requirements was developed. A large-area. 5-mil-thick. diffused-junction detector which is connected directly to a low input impedance, fast current amplifier is placed directly in the neutron beari from the ORELA. The low input impedance $(<3 \Omega$; and direct connection are necessary because an $\sim 500 \mathrm{pF}$ detector capacity and a conventional cable impedance would determine a pulse duration of a $\sim \mathbf{4 0}$ nsec.

With a rise time of $<1$ nsec and a gain of $\sim 70$, this amplifier-detector combination produced a pulse duration of $<15 \mathrm{nsec}$ and enabied a time-of-flight measurement of $\sigma_{\mathrm{f}}$ for a $128-\mu \mathrm{g}$ sample of ${ }^{249} \mathrm{Cf}$ with respect to ${ }^{235} \mathrm{U}$ over an energy range from $0.32 \mathrm{eV}$ to $1.5 \mathrm{MeV}\left(\sim 10^{7}\right.$ alphas/sec). Radiation damage required replacement of the diffused-junction detector after 10-15 hr usage. Wieasurements were made at $9.73 \mathrm{~m}$ in flight path 2 at the ORELA at an average power of $25 \mathrm{~kW}$.

A prominent feature of these results is that a very large resonance at $0.71 \mathrm{eV}$ accounts for $\sim 60 \%$ of all ${ }^{249} \mathrm{Cf}$ fissions observed in the experiment. These data overlap and extend to lower energies the unpublished results of Silbert measured on the Physics- 8 underground explosion.

1. Chemistry Division.

2. Physics Division.

3. Los Alamos Scientific Laboratory.

\section{I.6 THIN ${ }^{6} \mathrm{Li}(\mathrm{n}, \boldsymbol{\alpha})$ T TRANSMISSION FLUX MONITOR ${ }^{1}$}

\author{
R. L. Macklin ${ }^{2}$ \\ B. J. Allen ${ }^{3}$ \\ N. W. Hill
}

A thin glass scintillator system has been developed for fast time-of-flight neutron monitoring at the ORELA electron linear accelerator. Beam backgrounds under $1 \%$ from $6-100 \mathrm{keV}$, negligible environmental background, beam flash recovery in $1.25 \mu \mathrm{sec}$ and time resolution of less than $2 \mathrm{nsec}$ have been achieved on a $40 \mathrm{~m}$ flight path. The monitor can be used in transmission, on line introducing additional dips of less than $4 \%$ in the transmitted neutron spectrum at $55,200,240,440 \mathrm{keV}$ and higher from the constituents of the glass scintillator.

1. Abstract of article published in Nucl. Instr. Methods 96(4), 509-13 (November 1, 1971).

2. Physics Division.

3. ORNL and Australian Atomic Energy Commission, Lucas Heights, N.S.W. Australia. 


\title{
1.7 A HIGH RESOLUTION SPECTROMETER SYSTEM WITH PARTICLE IDENTFICA IION FOR I- THROUGH 6O-MEV HYDROGEN AND HELIUM PARTICLES'
}

\author{
F. E. Bertrand ${ }^{2} \quad$ W. R. Burrus ${ }^{3}$ \\ N. W. Hi!l T. A. Love ${ }^{4}$ \\ R. W. Peelle
}

A coincidence semiconduitor spectrometer system based on a Ge(Li) total absorption detector has been applied to the simultaneous spectroscopy of al: charge-1 and -2 particles from targets bombardeci with protons with energy up to $62 \mathrm{MeV}$. Output spectra cover the range from the full energy down to a 1 - to S-MeV threshold, which depends on the particle type. The method for choosing the thicknesses for the two $\Delta$ E detectors is discussed and unusuai fealures of the system are descrited.

Particles ton slow to penetrate the first $\Delta \mathrm{E}$ counter were sorted accurding to mass, using the flight-time vs $E$ discrimination, while the more ersigetic particles were separated using two sets of $\triangle E X E$ discrimination. Germanium derectors thick enough to stop $60-\mathrm{MeV}$ protons were used with particles entering perpendicular or parallel to the field lines, and, in either case, the only significant inactive region in the path of the detected particles was the protective foil over the $\mathrm{re}_{\mathrm{e}}(\mathrm{Li})$ detector. The typical pulse-height resolution of the system was about $200 \mathrm{kVV}$ for $60-\mathrm{MeV}$ protons, although a $\mathrm{Ge}$ detector used alone gave $55-\mathrm{keV}$ resolution at this energy.

Analysis was pelformed after the experiments using magnetic tapes vitten by an on-line computer; corrections to the pulse-height spectra for reaction and collimator tails are discussed. The electronic logic system is described, including portions for event characterization, for use on an "active" detector collimator, and for pile-up pulse rejection based on timing information.

1. Abstract of paper subnit ted for publication in Nuclear Instruments and Methods.

2. Phy sics Division.

3. Present address: Tennecomp. Inc., Ozk Ridge. Tennessee.

4. Neutron Physics Division.

\section{I.8 GATING UNIT FOR NEUTRON MULTIPLICITY COUNTER}
F. M. Glass
J. Halperin ${ }^{1}$
R. L. Macklin ${ }^{2}$
R. T. Roseberry
H. W. Schmitt'
R.W. Stoughton'

The continued search for superheavy elements in natural samples and accelerator targets through the use of a neutron multiplicity counter led to the development of a new gating circuit which is currently in use with the neutror. multiplicity counter previously described. ${ }^{3-6}$ This new gating circuit (Q-5138), which replaces the coincidence-anticoincidence unit previuusiy described, ${ }^{6}$ was designed to cover the total range of experimenter interest and to simplify acquisition and evaluation of daia.

In addition to the features of the old unit, the range of the riew unit was extended to recognize multiplicities up to 12. When more than one neutron is detected witiin the preset gating time, a pulse is generated and addressed to the scaler that cou.its that particular multiplicity (i.e., doublets, triplets, etc.). This gating unit also counts the total neutrons, total gates, and total number of overflows. The lengths of the coincidence and the inhibit (or anticoincidence) gates are controlled by a 1-MHz crystal-controlled clock and are variable to 999 and $900 \mu$ sec. respectively.

1. Chemistry Division.

2. Phy sics Divisicn. 
3. R. L. Macklin el al. "veulron Multiplicity Counter," Chemistry Div. Annu. Progr. Rep. May 20. 1971. ORNL-4706. pp. $87-89$.

4. R. T. Roseberny et al., "Neutron Multiplicity Counter Buffer Memon and Printer Control Logic," Insinumenration and Controls Div. Annu. Progr. Rep. Sept. I. 1, ?i. ORNL-4734, p. 3.

5. R. L. Macklin et al. "Neutron Muitiplicity Counter," Vucl. Instr. Methods 102i1), 181-87 ijuly 1. 1972).

6. F. M. Glass. "Coincidence-Anticoincidence Unit," Instrumentation and Controls Div. Anmu. Progr. Rep. Sept. I. 197l, ORNL-4734. p. 8.

\subsection{MULTIPARAMETER DATA ACQUISITION SYSTEM}

R.W. Ingle J.W. Reynolds

A system was designed and fabricated for use by the Neutron Physics Division for multiparameter exprriments using time-of-flight information and pulse iteight analysis. This system consists of a time digitizer, a dual analog-to-digital converter (ADC) system consisting of two 100-MHz ADC's with a data dig plexer, and a multiparameter interface module that was designed and fabricated at ORNL. The ADC system was modified to permit an entire read out of one ADC first when both ADC's have data simultaneously. Also, a second word of buffer storage was added to the digiplex unit to permit data handling at a more rapid rate. The system is undergoing final phases of testing.

The interface module, incorporating TTL integrated circuitry, accepts binary information from the time digituzer and pulse height digiplexer and transmits it to the ORELA jata acquisition computer through the isolator system. A matrix type patc: panel selects any combination of 30 bits to be handled by this module. Three modes of operation are selectable by selecting the appropriate ready signal: time digitizer, ADC, or dual. In the latter mode a ready fag from both ADC's is required before a system ready flag is presented to the computer. Two pulse-height sigrals can be handled with a single time-of-flight event by reading into the computer the information from the first $A D C$ with the time-of-flight value followed by reading in information from the secord $A^{T}, \mathcal{C}$ with the same time-of-flight value. The time digitizer is then cleared and becomes ready for additional information.

\subsection{CLOCK Ai:D READOUT CONTROL FOR FISH TAG EXPERIMENTS}

\section{F. W. Snodgrass}

Recording the temperature of a fish or of the surrounding water as a fish moves about in lakes and streams is a project of the Environmental sciences Division. An ultrasonic temperature-sensitive transmitter ${ }^{1}$ placed inside a fish transmits its temperature to a receiver and analog-to-digital converter in a boat. An instrument (Q-5153) was designed and built to punch this digitized temperature data and time of day on paper tape in ASCII format. The electronic time clock can be preset ind the data displayed by a solid-state readout device. Readout rates are selectable from once per second to once per hour.

1. J. M. Rochelle, Instrumento:ton and Controls Div. Annu. Progr. Rep. Sept. 1, 1971, ORNL4734, p. 10.

\section{II RIST TECHNICAL SERVICE UNTT NUCLEAR ELECTRONICS}

\section{J. M. Rochelle}

The RIST Technical Service Unit Nuclear Electronics (Q-5114) is a complete two-channel energy analysis system which includes four photomultiplier tube (PMT) high-voltage supplies, a precision mercury pulser, a main pulse amplifier, and two differential discriminators, each followed by a lngarithmic count-rate meter. These circuits were developed as part of a compact, rugged, battery-operated radiation 
detection and data acquisition system for the U.S. Army Corps of Engineers in making routme radioisotopic sand tracer studies. A primary objective in developnent of this unit was that all required electronic functions $u$ suld be in a single package and would use less than one-fourth the volume ard power required by the individual NIM standard modules used for the original RIST feasibility experiments.

The four, -1200 V. individually packaged PMT bias supplies can be independently energized from the $-12 \mathrm{~V}$ bus to enable operation of any combination of the four PMT's. (The scintillators, PMT's and charge-sensitive preamplifieı ar. contained in a special detector assembly which is towed along the ocean floor by a surface vehicle wl:ich also houses the Q-5114 technical service unit and accomparying digital equipment.) A potentiometer in series with the output of each supply enables small adjustments in the operating voltage for each PMT. The $-1200 \mathrm{~V}$ circuit is an adaption of a dc-to-dc converter (Q-2291). This class of converters exhibits good efficiency and excellent output voltage regulation over a wide range of inpuit vưtatas.

The precision mercury pulser has classical circuitry to obtain a fast-rising positive pulse with a $50-\mu$ sec exponential tail at a $90-\mathrm{Hz}$ rate and a $50-\Omega$ output impedance. The pulse height. derived from a stable Zener reference, is continuously variable from 0 to $300 \mathrm{mV}$ by a fron!-panel pot. Either the pulser output or the preamplifier output can be routed to the main amplifier input by a front-panel switch.

The pulse gain of the main amplifier is variable from $X 4$ to $X 320$ using $X 2$ coarse steps (constant impedance attenuators) and a $2.5: 1$ fine control. This gain is derived by ascading four operational amplifiers using monolithic integrated circuits for the first three stages and a high slew rate modular unit for the IO.V outgut stage required to drive an extemal pulse height analyzer. A separate, unity gain FET input amplifier provides the proper input for each differential discriminator. The overall gain stability is $> \pm 200$ ppn: $/^{\circ} \mathrm{C}$.

Excelleni amplifier pulse shaping and noise rejection are obtained by a passive, terminated $L-C$ filter. The resulting unipolar output pulse reaches a peak value at $\sim 5 \mu \mathrm{sec}$ and is almost symmetrical. No undesirable undershoot or ringing was observed, although the filter was fabricated using low-cost, $\pm 10 \%$ miniature inductors. Pole-zero cancellation and long coupling-time-constants aid in overload recuvery and prevent excessive base-line shift at high count rates.

Each of the two differential discriminators has a simple circuit with monolithic integrated circuit comparators but without the usual flip-flops or delay networks. The result is a fast discriminator with no dead-time beyond the width on an input pulse and with a temperature stability of $> \pm 100 \mu \mathrm{V} /{ }^{\circ} \mathrm{C}$ for the fully adjustable upper and lower discrimination levels.

The 100-nsec-wide discriminator output pulse, which occurs when the input pulse retums below the lower discrimination level, triggers a 1 - 1 sec one-shot for driving external counters and a logarithmic count-rate meter.

The four-decade ( 10 to 100,000 counts/sec) !ogarithmic count-rate meter has a novel circuit design that does not require independent decade calibrations or excessively large integrating capacirors. The unit is more compact, requires less critical components, and is theoretically nore accurate than the commonly used parallel-pump circuit configuration. Calibration requires use of two different count rates: one is obtained from a built-in 10-Hz. unijunction oscillator (which also serves to keep the logarithmic meter on scale in the absence of data input), and the other is the sum of the $10-\mathrm{Hz}$ oscillator and the $90-\mathrm{Hz}$ mercury pulser.

All of the Q-51 14 functions make maximum use of off-the-shelf integrated circuits, and any one could be parkaged in a single-width NIM module. In particular, both the differential discriminator and logarithmic count-rate meter could be mounted in one single-width module to create an instrument not presently available from commercial sources. 


\title{
2. Miscellaneous Electronics Development
}

\subsection{HYBRID MICROCIRCIITT ACTIVITES}

\author{
i. T. Ie Lorenzo \\ E. J. Kennedy: J.M. Rocitille C. H. Tucker
}

\begin{abstract}
A hybrid integrated circuit (IC) faciliy' was installed in the Instrumentation and Contruls Division so that ORNL would have a modest "inhouse" capability for fabrication of ic"s for small projects and Division engineers would gain an understanding of the fatrication process and its probtems. This knowledge will be particularly helpful when large quantities of IC's are purchased from industrial manufacturers. Small-volume orders from industry cannot be justified economically. The facility has a thermucompression and an ultrasonic wire bonder for making interconnections on nonolithic breadboard chips or for connecting low-cost transistor, resistor, and capacitor chips obtained from industry. The facility is used to maxe IC's for projects rather than just research and development devices because projects require engineering capability and pay for this service.

One of the first benefits of this facility was the production of IC's for the successiul development of electronic fish tags. ${ }^{2}$ Following this. an all-solid-state electiometer circuit that had been developed previously with disrrete comporients was selected for reduction to a hybrid IC with three chips for use in a portable beta-gamma survey instrument (Cutie Pie). Studies are being continued to make more improved and sophisticated fish tags. Another application is an evaluation of photographic and etching resulution by making thin-film resistor and conductor networks on commercially available metalizzed substrates. Many other circuits used 2: ORNL that possibly could be improved by hybrid packaging will be investigated as resources permit.
\end{abstract}

1. Consultant from the Electrical Engineering Department. the University of Tennescee, Knoxville.

2. J. M. Rochelle, "Ultrasonic Temperature Telemetry System for Tasging Fish," Instrumentation and Conirols Div. Annu. Arogr. Rep. Sep!. 1. 1971, ORNL-4734, p. 10.

\subsection{NIM SYSTEM POWER SUPPLY}
E. E. Waugh
G. A. Holt
C. C. Courtney
W. E. Lingar

A new NIM power supply (Q-3003B) with $96 \mathrm{~W}$ out :ut was developed. The supply will fit either 'ne $51 / 4$ - or the $83 / 4$-in. NIM bin. 
Typial ponver supoly specifrations sre
Inpul collap:
54: $129 \mathrm{~V} x, 605 t z .1$ phax.
Oulpuiz sullages.

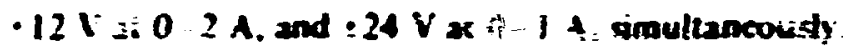
Lric :=inix:n:

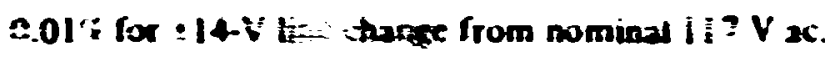
I.'3d rexulation:
c.3ir: for a kod change wis is to 1 A
Tesipe siure coefricicas

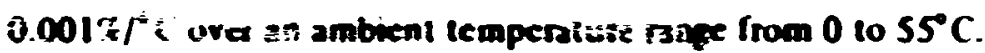
Nusce and repete:

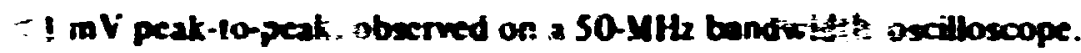
SA:ri-ciecuil prolections.

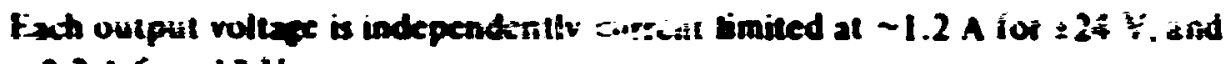 2.2 A for $: 13 \mathrm{Y}$
Ther mal putection:

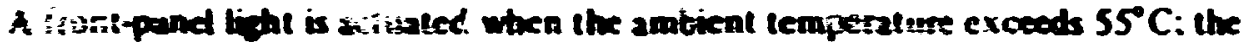 supply is iticinostatically turrice off, and a front-panel bight is atusted when the heat ink kexpsatise exceeds $95^{\circ} \mathrm{C}$.

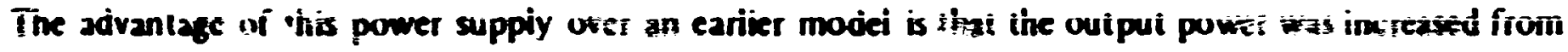
$721096 \mathrm{~W}$ without increasing the volume of the supply.

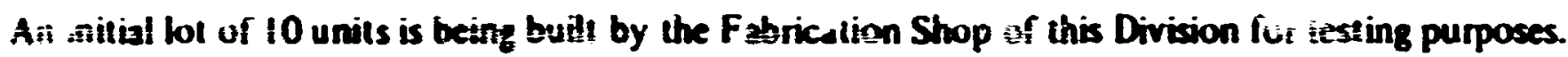

\subsection{IMPROVED NM LAMMATEU BUS}

\section{E. E. Waugh G. A. Holt}

An improved laminated wiring bus (Q2804 2S5) \%35 developed for the NIM system. This bus will eliminate much of the darnege to ithe contacts thit occurtet to the cld bus before being installed in a NIM bin. The feeder hook-up wires. soldered to the strip on the ofd bus. were replaced by copper strips that are an integral part of the new bus strip. The new bus is simpler and tess expensive and requires less space for installation in the NIM ben. A commercial supplier will fabricate 100 units for storts stock.

\subsection{ELECTROCHEMACAL AMBENT AIR MONITOR}

$$
\text { C.C. Courtney T. R. Mueller }{ }^{i}
$$

An electrochemical ambient-air monitor was developed under contract with the Air Programs Offic: of the Environmental Protection Agency.

The monitor was designed to be an easily modified electrochemical monitor that can be adapted to determine several different chemical species or to use different electrochemical techniques for a single -lement. It is being used as a chlorine-chloride monitor. with a range from 0 to $100 \mathrm{ppm}$ and a rexilution of $\pm 10 \mathrm{ppb}$.

The control unit for the air monitor has a plug-in etched wiring board which can be madified easily for different adaptions of the instrument. The control unit is packaged in NIM hardware and mounted in an instrument cabinet containing the air monitoring system.

1. Analy tical Chemistry Division.

\subsection{EMISSION-ABSORPTION PHOTOMETER}

\section{C. Courtney T. R. Mueller"}

A prototypic Emission-Absorption Photometer (Q-5134) was designed and fabricated for use with atomic absorption or flame emission photometric analysis. The instrument will be used initially for determination of mercury in food and ecological samples by flameless atomic absorption photometry. The 
photometer is packaged in a standard $8^{3 / 4}$-in-high by 19 -in. wide retay rack pane! and has plug-ill elched wiring boards to facilitate fabrication and maintenanieg. Oneation is tentrolled by pishbutton switches located on the front panel or reriotaly by DTL-TTL levels.

The instrument is equipped fur tw J-channel operation; the second channel signal is (1) derived internally as a fixed reference. (2) acquired through the channei i aniplifier, or (3) acquired through the channel 2 amplifiet or from a controlled externai suirce.

Mede 1 provides a simple iogarithmic readout of the photocurrent.

Mude 2 determines the intensity of th: photocurrent with no sample present and holds it as reference s'gnal. Subsequently, in the presence of an absorbing substance, the photocurrent is decreased. The concentration of the absorbing substance is determined in timic absirption photometry (AA) from the Beer-Lambert relation: $I=I_{0} e^{-k c i}$, where $I$ is the intensity of the light after passing through $I \mathrm{~cm}$ of an absowisg medium cuntaining $c$ inoles $/ \mathrm{cm}^{3}$ of the absorber with an absorption coefficient $k$, and $l_{o}$ is the intensity of the incident light.

Mode 3 fuinishes a reference sigial that an be programmed to simulate nonideal absorption cell behavior or can be used to provide a chopper chaminel for thame-excited atomic absorption analysis (to correct for tlame emission).

A digital panel meter from which a BCD coded output can be obtained is a convenient display of the log-ratio signal tor thameless $\mathbf{A A}$.

1. Anziytical Comistry Division.

\title{
2.6 IONIZATION CHAMBER CURRENT QUANTIZER FOR RADIOLOGICAL ENVIRONMENTAL MONITORING SYSTEM'
}

\author{
F. M. Glass
}

A current-to-frequency converter, having a total leakage current $<10^{-14} \mathrm{~A}$ was developed as an Ionization Chamber Current Quantizer. This ins:niment measures currents from $0.5 \times 10^{-10} 100.9 \times 10^{-6}$ A without range-switching, which conesponds to a radiation range from 0.5 to $10,000 \mathrm{R} / \mathrm{hr}$ when used with a 1000-i; slandard air equivalent chamber. The output of the converter is positive pulses having a frequency directly proportional to the ionization current. The calibration is adjustable within a range from $2.4 \times 10^{-11}$ to $9 \times 10^{-11}$ coulomb/pulse. Built-in current sources enable a check of the calibration. The instrument has a high tolerance for gamma radiation, hunidity, and ambient temperature.

1. Abstract of pubtished report ORNL-TM-3906 (August 1972).

\subsection{CRYSTAL CONTROLLED PULSE GENERATOR}

\section{F. M. Glass C. C. Courtney}

A pulse generator $(Q-2167)$ with a precise repetition rate was redesigned for use in calibrating count-rate meters because the decade dividers used in the $Q-2167$ unit are no longer commercially available. The new generator (Q-2167A) is half the size of the older one, covers a wider range of frequencies, and can be built for about $30 \%$ of the cost of the older unit.

The basic frequency is determined by a $1-\mathrm{MHz}$, crystal-controlied clock. The outputs from the generator are nominal 5-V-negative and -positive rectangular ;ulses having nominal widths of $600 \mathrm{nsec}$ and attenuated negative pulses with exponential R.C decays. The amplitude and decay time-constant can be varied by selector switches. Any one of 63 fixed frequencies from $0.1111 \mathrm{~Hz}$ to I $\mathrm{MHz}$ is selectable. 


\title{
2.8 COMPACT CHARGE-SENSITIVE PREAMPLIFIER FOR ${ }^{3} \mathrm{He}$ COUNTER
}
J. T. De Lorenzo
C. C. Courtney
D. D. Walker

Space limitations in a shield and breeder blanket to be tested at the Tower Shie!ding Facility for the Liquid-Metal Fasi Breeder Reactor program required a charge-sensitive preamplifier with physical dimensions smaller than could be purchased commercially. A circuit design based on that of Hill and Albritton' was modified and packaged in an enclosure approximately 2 in. in diameter and 4 in. long to satisfy the unique requirement.

1. N. W. Hill and W. P. Albritton, "An Input-Capacity-Insensit. re, Charge-Sensitive Preamplifier for Simultaneous Use in Vacuum with Fast Amplifiers for Charged-Particle Studies with Semiconductor Detectors," Nucl. Instr. Methods 7S(1), 1828 \{1969).

\subsection{EVALUATION OF THE CD V-7i5-1 SURVEY METER AS 4N EDUCATIONAL TOOL}

\author{
F. M. Glass
}

The CD V-715-1 ionization chamber survey instrument was evaluated for use as a science classroom instrument. Detailed instructions were prepared for converting the instrument into an electrometer suitable for science classes. The conversion requires only materials that are commonly available to science c'ass rooms and cost less than $\mathbf{5 1 . 0 0}$. Comprehensive operating instructions were prepared for using the electrometer to measure small currents. Procedures fcr conducting many classoom experiments were also prepared. These experiments require only common and inexpensive materials that are availabie to mosi studeri:is without cost.

This work was performed under OCD contract DAHC 20-72-C-0011.

\subsection{ULTRASONIC FISH TAG IMPROVEMENTS}

\section{J. M. Rochelle}

An improved circuit was designed for the Ultrasonic Fish Tag (Q-5099) $)^{1}$ developed for the Environmental Sciences Division, aliowing physically smaller tags with a longer battery life. Niew tags only 1 in. long function for rearly a year, and up to two years of useful life can be obtained with tags $1 \frac{1}{2}$ in. long. Temperatures measured by these tags are accurate to within $\pm 0.2^{\circ} \mathrm{C}$.

This work will be contirued to further reduce the tag size and to develop a depth measuring tag.

1. J. M Rochelle. "Ultrasonic Temperature Telemetry System for Tazing Fish," Instrumencetion and Conmols Div. Annu. Pross. Rep. Sept. 1. 1971. ORNL-4734 (July 1972), P. 10.

\subsection{RADIATION DETECTOR CIRCUIT FOR AUTOMATED ATTACK-EFFECTS INFORMATION SYSTEMS-I}

\section{F. M. Glass C. C. Courtiey}

An engiriezring study was made to determine the most acceptable radiation detector and electronic circuit for the Automated Attack-Effects Information Systems-1 within the following guidelines.' The detector and elecironics must be compatible with the concepts set forth in the Stanford Research Institute report. Cost and power consumption are major considerations because a large number of instrumetits will be required for a lationwide system, and the instruments should continue to operate for several weeks after a major power failure. Other essential chararteristics are extremely wide range (four decades). good 
radiatical immunit; [includin ¿ electromagnetic pulse (EMP)], acceptable energy response, and ability to jerforn for many years in hostile environments.

Our approach to radiztion inmunity is to design a compact circuit that can be shielded easily. Two detector systems weic designeri, with integisting pulse discharge ionization chambers as the detector, and we believe that these detecto-s will meet all the requirements except cost. Both circuits have COS/MOS ${ }^{2}$ integrated circuit logic. One of these units should also meet the cust requirement when built in quantity. This circuit is currently being built for test and evaluation, including radiation damage testing.

This work was performed under OCD Contract DAHC 20-69-C-0132.

1. R. W. Strunk and M.S. Colah, Automated Attack-Effects Information Systems-1, Stanford Research Institute, OCD Contract DAHC-20-67-C-0136.

2. Manufacturer's designation for complementary symmetry metal oxide semiconductor IC's.

\subsection{ENGIINẼERING STUDY OF A MODIFIED E-H ELECTROMETER MODEL 202}

$$
\text { F. M. Glass W. E. Lingar }
$$

An engineering study was made to determine the cause and correction of a constant drift and high incidence of failures in CK5889 electrometer tubes in the input of Q-2338-j R1 electrometers, which are E.H model 202 electrometers modified for use in the High Voltage Laboratory Radiation Monitoring System. ${ }^{1}$ Small changes in the iransconductance of twelve CK5889 tubes were observed for four months at given heater voltages and cathode currents. A conclusion from this study was that four minor circuit changes would virtually eliminate these tube problems, so current sources were installed in seven electrometers as a convenient calibration check.

1. W. E. Lingar, "High Voltage Laboratory Radiation Monitoring System," Instrumentation and Control; Div. Annu. Prozr. Rep. Sept. : 1962. ORNL-33i8, p. 26.

\subsection{INVESTIGATION OF UNREUABILITY OF MAGNET CURRENT SOURCE}

\section{W. E. Lingar}

An investigation was made to determine the cause of unreliable operation of a $25 \mathrm{~kW}$ current-regulat.d magnet supply that is used for research with the Tandem Van de Graaff machine in the High Voltage Laboratory.

We concluded that a rapid change in the current through the magnet induced a high voltage across the transistor bank which exceeded the voltage rating of the transistors and caused them to fail. Also, the power rating of eact emitter resistor was less than the rating of the emitter fuse. Thus, when a transistor failed, the emitter resistor was destroyed instead of the iuse element. Means of correcting these design deficiencies are being considered.

\subsection{GROUND ISOLATION' CARD TESTER}

\section{J. W. Reynolds}

A tester was designed with DEC R Series flip-chip modules and constructed in a two-unit-wide NIM chassis to allow off-line testing of eigit types of ground isolation circuit cards used by the ORELA data handling system. The ground isolation of $10^{10} \mathrm{~S}$ : per digital circuit is provided by a signal-powered oscillator-transformer-transistor combination of components.

The off-line testing of suspected failures allows a minimum downtime (to change a card) of the data acquisition system which operates around the clock. The tester also supplies a fixed-frequency, 
variable-width pulse in place of the random data bits. The tester has been used tu pretest the isolater ards DAC-1, DAC-2, and the Phase 111 computer ground isolation.

There was one circuit failure of 521 installed since completion of the iristallation ia February 1972.

An operators instruction manual was prepared.

1. J. W. Reynolds and R. P. Rosenbaum, Instrumentation and Controis Dis. Annu. Progr. Rep. Sept. 1. 197I. ORNL-4734, p. 27.

\subsection{DATA ACQUISITION TESTER FOR THE ORELA}

\section{J. W. Reynolds}

A tester was designed with DEC M series logic modules and constructed in a four-unit-wide NIM module to aliow on-ine checking of a multiplexen chantei or a stakeı interface with a knuwn data patiern su that an intermittent hardware error could be located anywhere in the data acquisition hardware. The detected enrors, bit pick-ups and dropouts, are displayed on a CRT with the display software used by the experimenters at the ORELA. The data acquisition hardware from the experimenter to the computer input-output bus are a stacking buffer memory, ${ }^{1}$ a patch panel, ground isolation for a multiplexer channel. and channel gating for the multiplexer interface to the SEL 810B input-output bus. In addition, the tester will be used by Systems Engineering Laboratories in the fourth quarter of 1972 to perform in-plant lesting of the multiplexer and scaler interfaces on DAC-3.

1. R. E. Wintenberg, J. W. Reynolds, and A. R. Smith, Instrumeritation and Costrols Div. Annu. Progr. Rep. Sept. I. 1971. ORNL-4734, p. 34.

\subsection{ZEBRA-STRIPE MICROWAVE INTERFEROMETER FOR ORMAK}

D. D. Bates

To measure the plasma density in the ORMAK, a microwave interferometer (Fig. 2.16.1) of the zebra-stripe type was developed.

Power from the swept klystron is divided into two paths. The reference path is short so that phase shifts are negligible. The plasma path, however, is long so that. as the frequency of the klystron is swept. the phase relationship of the two paths changes. The mixer supplies an output signal to the $Z$ axis of the oscilloscope to enhance the trace when the signals are in phase. For ORMAK, the plasma path was made long enough that the signals would be in phase at least three times during the sweep of the klystron to furnish three unblanking pulses to the scope. With the horizontal sweep of the scope set at a low value compared with the klystron sweep, the fringe patterns of the three interferences arc portrayed.

The operation described above is the steady-state condition without a plasma. As the plasma builds up between the horns, the effective dielectric constant changes by an amount determined by the plasmia density between the horns. The effective path length of the plasma is thus changed, resulting in a phase change of the signal in the plasma path and a shift in the location on the scope at which the uriblariking occurs. The density of the plasma can thus be determined by measuring the number of fringe shifts on the scope.

Components were ordered to build a second interferometer system, and, if the power írom the klysiron can be divided to drive two plasma paths, the two systems will be combined to provide four channels of information on the ORMAK plasma density profile. 


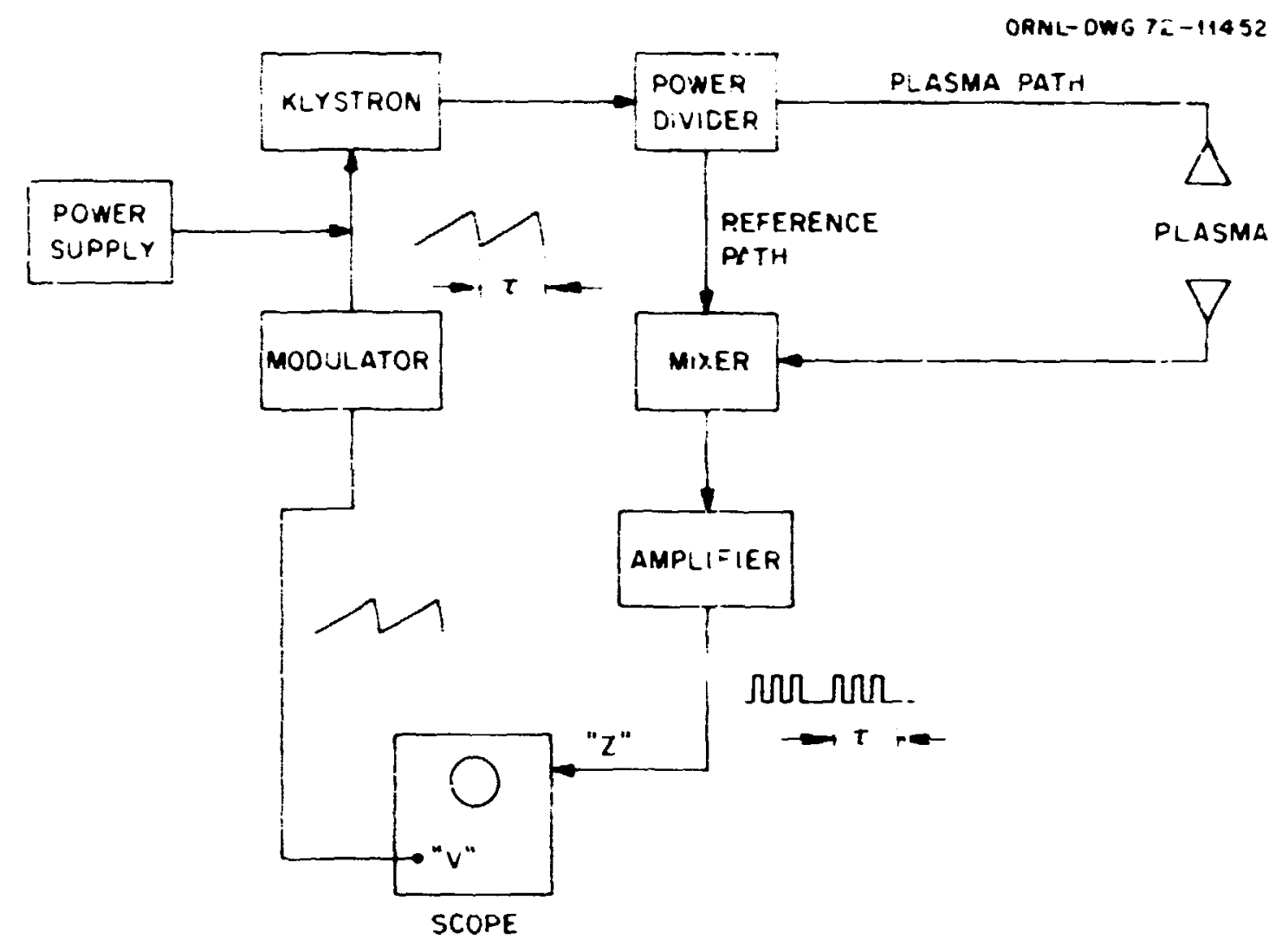

Fig. 2.16.1. Diagram of microwave interferometer.

\section{1: MICROWAVE PREIONIZATION GENERATOR FOR ORMAK}

D. D. Bates

An 8-mm microwave generator was designed to supply microwave energy to preionize the $\mathrm{p}^{\prime} \mathbf{2 s m a}$ in ORMAK. A surplus radar transmitter was modified and used as the output stage of the gencrator to generate the $40-\mathrm{GHz}, 40 \mathrm{~kW}$ pulses.

The control unit for the generator contains the oscillatcr and control logic to operate tine generator only during an OR:IAK shot. The unit preheats the magnetron filament and turns on the high voitage 30 sec prior to the shut. and then provides $4-$ or $8-\mathrm{kHz}$ trigger pulses to the microwave generator during the shot. Thus, the life of the magnetron is greatly enhanced, since it oferates only for about $0.5 \mathrm{sec}$ during each experimerit.

\subsection{FAST IONIZATION GAGE FOR ORMAK}

D. D. Bates

During the 100-msec experiment run time of ORMAK, the pressure in the liner changes two to three orders of magnitude. The feedbaci system of a standard VEECO model RG 31X ionization gage was modified to aliow the gage to respond in about $1 \mathrm{msec}$ to the fast changes in p: sssure. The pressure (torrs) is displayed on the vertical axis of an oscillescope vs elapsed time of the experiment on the horizontal axis.

\subsection{FAST ION GAŨE REGULATOR}

R. E. Wintenberg

An updated, repackaged version of the Thermonuclear Division Fast Ion Gage Regulator, Mark II, was designed for the ELMO Bumpy Torus Experiment.' This version his four ion gage control units per chassis, 
One electrometer, and a switched front-panel readuut having both analog and digital pantel meters. Separate commerial power supplies enable a more compat arrangement.

1. R. A. Dundl et al., The El.YHO Bumpy. Torus Experiment. ORNL-TM-3694 (November 1971 ).

\title{
2.20 MINIATURIZED SELF.CONTAINED AMPLIFIER
}

\author{
R. E. Wintenberg
}

A r.iniature. battery operated, general purpose, amplifier was designed for the Thermonuclear Division ELMO Bumpy Torus Experiment.' The amplifier has a gain of 100 , from do to $10 \mathrm{kHz}(-3 \mathrm{~dB})$. It is packaged in a 2.2 in. $^{3}$ box having a male and a female BNC connector on opposite ends. The majc components are a $\mu \mathrm{A}-776$ operational ampififier, four type-675 mercury celis, an on-off switch, arid a balance pot. The input resistance is $100 \mathrm{k} \Omega$, the output swing is $\pm 2 \mathrm{~V}$ into $5 \mathrm{k} \Omega$, the output noise is $\pm 2 \mathrm{mV}$ peak, and the no-load battery drain is $100 \mu \mathrm{A}$.

1. R. A. Dandl et al., The EL.hO Bumpy Torus Experiment, ORNL-TM-3694 (November 1971).

\subsection{GROUND FAULT DETECTOR}

\section{R. E. Wintenberg}

A ground fault detector was designed for the Thernonuclear Division ELMO Bumpy Torus Experiment. ${ }^{1}$ The detector measures the ohmic resistance to ground of a float ing 2.5-MW dc generator and its connected load. The detector will operate in $10 \mathrm{~V}$ of 60 cycle ripple and commutator noise on a bus having as much as $0.5 \mu \mathrm{F}$ capacity to ground.

The detector operates as follows: a $93-\mathrm{Hz}$ current is ac coupled into the generator bus which forms part of a bridge circuit; a synchronous FET switch samples the bus voltage and drives an integrator. Changes in phase cause the integrator-me ter amplifier to produce an output; $60 \mathrm{~Hz}$ and other frequencies average out. DC on the bus is blocked by the bus coupling capacitor and transients are clamped with Zerer diodes. An alarm circuit drives an annunciator. The unit is packaged in a two-unit-wide NIM module.

1. R. A. Dandl et al., The El.MO Bumpy Torus Experiment. ORNL-TM-3694 (November 19'i1).

\subsection{MEASUREMENTS OF THE SHIELDING EFFECTIVENESS OF COAXIAL AND TWO-CONDUCTOR CABLES'}

\section{J. T. Le Lorenzo}

A technique to measure the effectiveness of shields on coaxial and two-conductor cables was developed and applied to several different types. Surh measurements require considerable skill, and the published literature does not describe methods adequately to make reliable measurements without extensive experimentation and. very likely, misleading results. This paper describes this measurement technique and gives results on several cables. The reliability of the measurement was verified by comparing calculated and measured results for a solid copper-sheathed coaxial cable.

1. Abstract of published article: Rer. Sci. Insir. 43(1), 161 -64 (January 1972). 


\title{
2.23 MEASUREMENT OF SHIELDING EFFECTIVENESS OF HIGH TEMPERATURE COAXIAL CABLES
}

\author{
J. T. De Lorenzo \\ $\begin{array}{lll}\text { W. T. Clay } & \text { W. H. Houston } & \text { D. P. Roux }\end{array}$
}

The shielding effectiveness ${ }^{1}$ of SODERN high temperature coaxial cables was measured over a range of frequencies from $20 \mathrm{kHz}$ to $10 \mathrm{MHz}$. These cables, constructed with a composite jacket (stainless steel-copper-stainless steel) and designed for operation at $600^{\circ} \mathrm{C}$, are intended for use in the low-level neutron flux nunitoring channels in the LMFBR program.

The measured data are very close to theoretical predictions. At $5 \mathrm{MHz}$, a value of $2 \times 10^{-6} \Omega / \mathrm{m}$ was measured for a 4 -mm-diam cable. This can he compared with $\sim 2 \times 10^{-3} \Omega / \mathrm{m}$ for RG $233 / \mathrm{U}$ (a) double-braicied, $50-2$ cable) and for a 4-mm cable with an all-stainless-steel jacket. At $2 \mathrm{MHz}$, these values are $\sim 10^{-4}, 2 \times 10^{-3}$, and $2 \times 10^{-2} \Omega / \mathrm{m}$, respectively, for these three cables.

The excellent perfumance of the $4-\mathrm{mm}$ cable was a factor in its selection for use in the ORNL high-temperature fission ccunter developinent program (Sect. 8.16).

1. J. T. De Lorenzo, "Measurements of the Shielding Effectiveness of Coaxial and Two-Conductor Cables," Rev. Sci Instr. 43(1), $161-64$ (January 1972).

\subsection{BATTERY OPERATION OF INSTRUMENTS FOR FIELD EXPERIMEPTS}

\author{
J. M. Rochelle
}

The majority of modem scientific instruments (including NIM bin power supplies) are operated from a standard $115-\mathrm{V}$ ac power source. When these instruments are to be operated in undeveloped or inaccessible locations, the supply of electrical power to the instruments becomes a major engineering consideration. For larger, relatively fixed installations requiring more than about $100 \mathrm{~W}$, the power is usually supplied by some type of fuel-consuming plant such as a gasoline motor-alternator.

In many environmental studies, however, the instruments must be portable. Many could easily be powered from a standard $12-\mathrm{V}$ automobile battery by using an interfacing device to convert the battery voltage to the required instrument voltages which in many cases are $<50 \mathrm{~V} \mathrm{dc}$.

If the instruments used accept only i $15 \mathrm{~V}$ ac (i.e., if a stepdown transformer and voltage regulators are built in) and if weight is not a major fictor, then the logical choice for battery interfacing would be a high quality dc-to-ac inverter. There is. however, a large class of instruments that do not have internal power supplies and must be supplied directly with regulated dc $v$ sltages. Included in this class are many commercial subsystems such as tape recorders, data converters, miaicomputers, digital panel meters, and many of the NIM packaged instruments, including those designed at ORNL.

For supplying battery power to this class of instruments, a triansformerless dc-to-dc converter (Q-5113) was developed. A shunt-type switching circuit permits any one or morn regulated voltages between +2 and $+50 \mathrm{~V}$ to be produced from a single $12 . \mathrm{V}$ battery. Units with output roltages of $+5,+12$, and $+24 \mathrm{~V}$ were developed and they are being used with the RIST Technical Service Unit (Sect. 1.11). Negative voltages and other positive voltage values could be obtained with minor modifica ions.

The Q-5113 converter output voltage regulation is better than $\pm 0.5 \%$ over an input voltage range from 10 to $14 \mathrm{~V}$ and about $1 \%$ from no load to full load of $25 \mathrm{~W}$. Regulation sver a temperature range from 0 to $50^{\circ} \mathrm{C}$ is better than $\pm 0.1 \%$, and the output noise and rippl: is $<10 \mathrm{mV}$ peak-to-peak. The operating efficiency is $\sim 75 \%$. 
These versatile units. two of which can be packaged in a standard. double-width NIM module, should be useful for many field experiments requiring battery powered nuclear instrumentation, particularly when weight limitations prohibit the use of the standard NIM power supply driven by an inverter.

\subsection{INSTRUMENT FABRICATION}

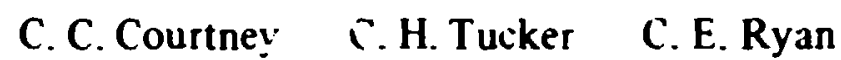

Newly developed prototypes of electronic irstruments thai required skilled and special fatrication techniques or the quantity required was too small io be of commercial interest were constructed by the Fabrication Shop of the Instrumentation and Contrals Division. The following instruments are examples of the service perforned by the Fabrication Shop.

A stack monitoring system designed by ORNL to monitor flue gases for alpha or beta-gamma radiation was constructed for the New Brunswick Laboratory of the U.S. Atomic Energy Commission. The system consists of an alpha monitor (Q-2362-3), a beta-gamma monitor (Q-2362-2), a commercial anemometer with a count-rate meter (Q-2714), and a irystal-controlled pulse generator (Q-2167A) to check and calibrate the system.

An improved model of the Cyclic Voltammeter' (Q-2943A) was constructed for the Analytical Chemistry Division. The new model will give more stable operation with different cells and a grounded working electrode. A first-deri rative and integrator module (module $\mathrm{E}$ ) was also added to the instrument.

Log electrometer in:trur:ients (Q-2957B) and G-M tube background-monitoring instruments (Q-5027) were fabricated for the Defense Civil Preparedness Agency for a radiological environmental monitoring system.

In addition to fabrication of all etched wiring boards for construction of electronic instruments, the etched-wiring-board facility was used for development of techniques to fabricate hyb.id integrated circuits.

Almost all of the non-NIM system electronic instruments constructed in the Fabrication Shop are equipped with NIM system hardware. The NIM system hardware has been used at ORNL since 1964, and its continued use is due prinarily to its versatility and low cost. The prefabricated parts are easily assembled, and they can be arranged or modified to fit most packaging needs.

1. C. C. Cóntney, J. T. Hutton, and T. R. Mueller, Instrumentation and Controls Div. Annu. Progr. Kep. Sept. I, 1970, ORNL-4620, p. 9.

\subsection{APPROVED WIRING DEVICES}

\section{G. A. Holt H. N. Wilson}

The Division provided continuing support to the Laboratory program of upgrading the wiring devices used in instrument construction and building wiring and on portable tools. Almost all "Crowfont" polarized wiring devices used throughout the Laboratory for building wiring were eliminated and replaced with single-voltage-rated, two-pole, three-wire grounding derices that are approved by Underwriters' Laboratories and will enable safer operation of instrumentation, apparatus, and portable tools.

The wiring devices used with the 120-208 V, three-phase, wye-connected electrical service in common use throughout the Laboratory were studied. A choice of four-pole, five-wire grounding devices for this service was suggested to the Laboratory Safety Committee.

Wiring devices were prosuref, tested, evaluated, and selected for general Laboratory use. The devices selected are safe and meet or exceed quality and performance requirements of the American National Standards Institute, the Underwriters' Laboratories, and the Occupational Health and Safety Act of 1970. A comprehensive line of the selected wiring devices is being procured, and the units will be stocked in both the General and the Electronic Stores at ORNL. Th.ese devices should meet the anticipatec needs of the Laboratory for the next several years. 


\title{
3. Detectors of Ionizing Particles and Radiation
}

\subsection{MULTIWIRE PROPORTIONAL COUNTERS}

\author{
$\begin{array}{lll}\text { H. R. Brashear } & \text { G. W. Allin } & \text { H. O. Cohn }\end{array}$
}

Construction of 20 multiwire proportional counters was started in support of the Physics Division participation in experiments at the 30-in. bubble chamber facility at the National Accelerator Laboratory. Charged particles with energies from 30 to $500 \mathrm{GeV}$ will traverse the bubble chamber. Tc calculate the momentum of the particles, the downstream traiectories of the particies will be determined with these proportional counters.

The particle trajectories will be defined by groups of counters at four locations along the beam line. At each location, at least three counters will be mounted with the anside planes parallel to each other and perpendicular to the beam line; the direction of the anode pianes will be $120^{\circ}$ with respect to each other. Any one counter at a location will yield a one-dimensional coordinate to \pm 0.0393 in. of the traversing particles. Two anode planes at right angles will yield two-dimensional coordinates of the particles, but these could be ambigious owing to the simultaneous arrival of several parricles. Three an Jdes will also give two-dimensional coordinates and reduce the chance of ambiguity significantly. At some locations, additional counters will be mounted to simulate a counter with 26 wires/in. to improve the resolution of the coordinate measurement of the particles.

Each counter has a sensitive area of $1 \mathrm{ft}^{2}$. Stainless steel, 0.0008 -in.-diam anode wires are spaced 13 wires/in. (156 wires; counter). High voltage-to-anode spacing is 0.218 in. A separate amplifier and lower level discriminator are provided for each anode wire. Signals from the amplifiers are driven differentially to a central loration and stored on magnetic tape for processing at a later time.

1. Physics Division.

\subsection{SUPPORT FOR NEUTRON CROSSSECTION MEASUREMENTS}

\section{F. E. Gillespie}

Construction of additional fission chambers was started for use in neutron cross-section measurements by the Neutron Physics Division. These chambers contain ${ }^{235} \mathrm{U}$ and ${ }^{239} \mathrm{Pu}$ foils that were analyzed fur uniformity and absolute amouni of material. The backing material is 0.5 -mil-thick Al cemented to 5-mil-thick Al rings with a super-refractory cement, C-10. The latest fission chamber (Q-2851 model VIHI) was designed for ease of changing foils and uses a $1 / 16^{-}$-in. cross-section Quad ring. This chamber has 2-mil-thick $P_{1} \mathrm{l}$ end windows and requires a special fixture for pumping and filling.

$A{ }^{10}$ B-coated plate was used in a neutron beam monitor. This design (Q-5087) is a symmetrical Frisch grid chamber. Both ${ }^{7} \mathrm{Lij}$ peaks $(0.48$ and $0.56 \mathrm{MeV})$ and both alpha paricle peaks ( 1.53 and $\left.1.86 \mathrm{MeV}\right)$ can 
be resolved. The center plate is coated on both sides with $\sim 10 \mu \mathrm{g} / \mathrm{cm}^{2}$ of ${ }^{10} \mathrm{~B}$ on aluminized Mylar. The grio plates are 5-mil-diam Al wires spaced 0.050 in. apart. The collector plates, aso aluminized Mylar, are used for the slow signals where pulse height information is obtained. The center boron-coated plate is used for the fast timing pulse.

\subsection{EXPLRIMENTAL ELECTRONIC ACTIVITIES}

\section{J. H. Todd R. W. Ingle}

Contin jing assistance was given to a program in the Neutron Physics Division for measurement of both capture and fission cross sections of fissile isotopes ${ }^{233} \mathrm{U},{ }^{235} \mathrm{U},{ }^{238} \mathrm{U},{ }^{239} \mathrm{Pu},{ }^{240} \mathrm{Pu}$, and ${ }^{241} \mathrm{Am}$.

Development of neutron flux measurement devices was continued, including gas-filled fission counters, parallet-plate $\mathrm{BF}_{3}$ counters, and lithium-loaded glass scintillation detectors. Each of these devices has limitatiuns, such as signal to noise and uniformity of response. Studies of organic scintillators were started.

Instrumentation consisting mostly of the system previously in use at the 40 -m flight station was completed for a new 150-m flight station to be used to extend the high-energy region of cioss-section measurements. Work was also started on a new 95-m flight station.

\subsection{X-RAY DIFFRACTOMETER BEAM MONITOR IONIZATION CHAMBER ${ }^{1}$}

\section{R. E. Zedler}

A small ionization chamber was designed and built for the Metals and Ceramics Division to monitor the incident beam betyreen the entrance siit and the bridge of a Kratky small-angle $x$-ray diffractometer. The beam : $\sim 32 \mathrm{~mm}$ long and $i \mathrm{~mm}$ wide. The outer dirnensions of the chamber are $1 / 2$ by $1 / 2$ by $3-1 / 4 \mathrm{in}$. long. Beryllium windows are used over the $1-3 / 8$-in.-long, $3 / 16$-in.-wide entrance and exit slits. The sensitjve volume of the chamber is $2.5 \mathrm{~cm}^{3}$. The chamber is filled with argon-10\% methane to $76 \mathrm{~cm}$ pressure

With the chamber monitoring the incident beam produced by a molybdenum target operated at $50 \mathrm{kV}$ and $18 \mathrm{~mA}$, a chamber current of $1.65 \times 10^{-9} \mathrm{~A}$ is produced. The measured transmission loss of the chamber is $8 \%$.

1. Abstract of part of a paper to be published by R. Hendricks, F. M. Glass, J. T. De Lorenzo, and R. E. Zedler.

\subsection{VARIABLE ELECTRODE SPACING ${ }^{252}$ Cf FISSION CHAMBER}

\section{M. Chiles}

A fission chamber (Fig. 3.5.1) was designed for investigating electron collection time as a function of electrode spacing, gas pressure, and electrode voltage. The electrode spacing can be varied from $0.5 t, 5.0$ $\mathrm{mm}$ by an extemal swivel point micrometer adjustment. This range of adjustment changes the gas pressure only $5 \%$. The chamber can be filled to a maximum pressure of $3 \mathrm{~atm}$ abs.

This chamber can be used to experimentally determine the optimum parameters to achieve minimum electron collection time for resolving each fission pulse. From this timing information the maximum amouint of ${ }^{252}$ C.f usable in a chamber for a randomly pulsed reutron source ${ }^{1}$ can be determined. Requirements for the electronic equipment can also be obtained.

1. M. M. Chiles, "Double Containment ${ }^{252}$ Cf Fission Chamber," Insinumentation and Controls Div. Annu. Progr. Rep. Sept. I, 1971, ORNL-4734, pp. 15-16. 


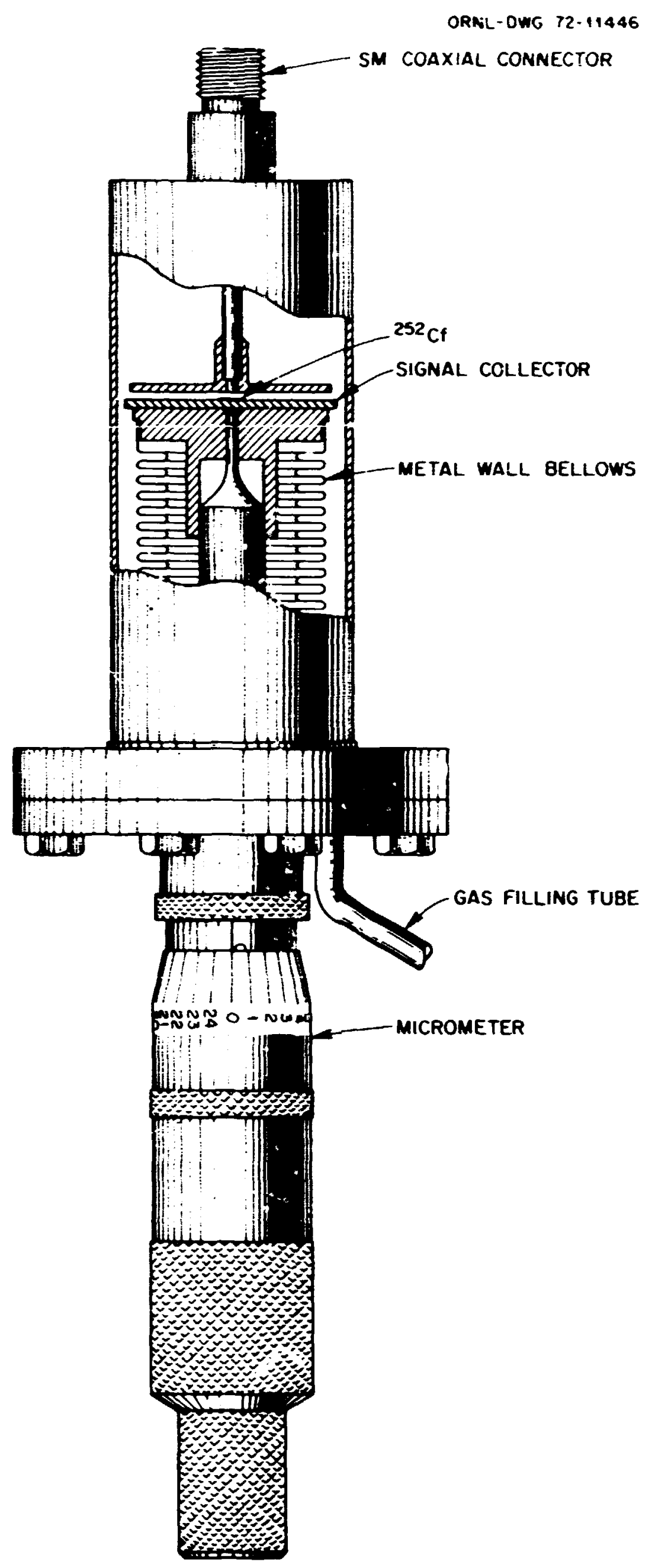

Fig- 3.5.1. Fiscion chamber Q-5128. 


\title{
3.6 METHOD FOR REMOVAL OF WATER VAPOR AND OXYGEN FROM PROPORTIONAL COUNTER GAS
}

\author{
R. E. Zedler
}

The ultimate energy resolution of a proportional counter is frequently limited by electron-attachiaig impurities in the gas mixture. Water vapor and oxygen are two such impurities. They are usually present in excess of 3 ppm in most gases. They may also be evolved from intemal counter surfaces and components, thus causing additio: al gas contamination.

In recent years Ridox ${ }^{1}$ has been used to reduce the oxygen content of inert and certain other gases to $<1 \mathrm{ppm}$ and molecular sieves ${ }^{2}$ to reduce the water content also to $<1 \mathrm{ppm}$. The effectiveness of these materials for purifying certain proportional counter gas mixtures was tested. Several grams of Ridox and 5- $\AA$ molecular sieve pellets were put in a thin-wall stainless steel tube which was then sealed to the counter.

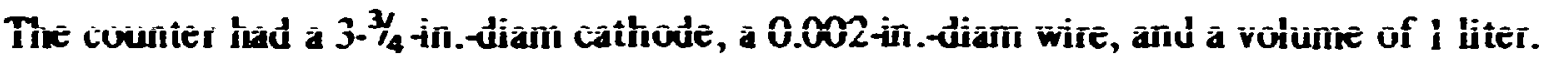

After the Ridox was chemically activated ano the $5-\AA$ molecular sieve and Ridox were outgassed, the counter was filled with $83 \mathrm{~cm}$ of xenon and $1 \mathrm{~cm}$ of cyclopropane, and $850 \mathrm{ppm}$ of oxygen was added. The initial resolution for ${ }^{109} \mathrm{Cd} 22.16-\mathrm{keV} \times$ rays was $11.5 \% \mathrm{fwhm}$. Then, $18 \mathrm{hr}$ later the resolution had improved to $7.8 \%$, and after two days it was 7.6\%. Equally successful results were achieved with $1300 \mathrm{ppm}$ of water vapor added it the mix ture.

The same counter was refilled with a high-purity mix ture of $78 \mathrm{~cm}$ of xenon and $8 \mathrm{~cm}$ of methane. The initial resolutiv: was $9.1 \%$, and after two days it was $8.2 \%$. After five months the resoluiion was $8.0 \%$, even though the courste: components were sealed with four Viton 0 -rings.

Traces of oxygen and water vapor have a much more detrimentai effect at high gas pressure.

A smaller ( $1-1 / 2$-in.-diam) high-pressure detector with Ridox and $5-\AA$ molecular sieve traps was filled with supposedly high-purity gases $-10 \mathrm{~atm}$ of xenon and $14 \mathrm{~cm}$ of methane. Initially, the 59.7 -keV gamma ray of ${ }^{241}$ Am was not resolvable. After $16 \mathrm{hr}$ of heating the Ridox to $110^{\circ} \mathrm{C}$ to accelerate gas diffusion and the reaction rate, the $59.7-\mathrm{keV}$ gamma ray wo resolvable and was $17.3 \%$ fwhm. Continual periodic heating for several weeks improved the resolution to $12.1 \%$, at which point the resolution was limited by other factors.

1. Ridox, by Fisher Scientific Supply Co.

2. Linde molecular sieves, by Union Carbide Corp.

\subsection{LOW-LEVEL DETECTOR FOR ALPHA CONTAMINATION MONITOR IN CONTINUOUSLY FLOWING PROCESS WASTE INATER'}

\author{
M. M. Chiles
}

A low-level alpha detector was designed and developed for monitoring waste water continuously flowing from radiochemical processing plar:ts and other facilities to determine whether these discharges contain alpha contamination. This detec'or encbles constant and automatic monitoring, with actuation of an alarm signal immediately on detection of alpha contamination. The alpha particles are detected by a 5-in.diam zinc sulfide scintillator, and the light flashes from the scintillator are detected by a 2 -ill.-diam photomultiplier tube. The alpha sensitivity of the detector is $\sim 1 \times 10^{-9}$ curie $/ \mathrm{ml}$ of ${ }^{238} \mathrm{U}$. Ten units have been fabricated and placed in sorvice at Oak Ridge National Laboratory.

1. Abstract of article to be submitted for publication. 


\title{
3.8 STATUS OF APOILO SPACE PROGRAM SUPPORT
}

\author{
V. A. McKay \\ R. T.'Roseberry T. F. Sliski R. E. Wintenberg
}

In June 1966, this Division was requested to help assemble a logic unit and detectors for a prototypic gamma-ray spectrometer to be fabricated at ORNL. The primary purpose of this work was to validate a design for a spectrometer to be constructed at the Lunar Receiving Laboratory (LRL) at the Manned Spacecraft Center in Houston, Texas. The LRI system was scheduled for construction in 1967 and mission simulation in October-November 1968. Pior to involvement by this Division, two sodium iodide detectors and PDP-9 computer had been ordered, and preliminary design concepts had been established.

Each specialty required for design and fabrication of the ORNL prototype - electronics design, computer technology, mechanics of operation and sonstruction, detectnr design and construction, and coordination - fell within the talents of this Division. In the above order, R. E. Wintenberg, R. T. Roseberry, T. F. Sliski, and V. A. McKay of this Division were assigned responsibility for producing the prototypic system. ${ }^{1}$

The knowledge obtained from. construction of the prototype, i.e., mechanics, low-radioactivity materials search, ${ }^{2}$ electronic modifications (logic, interfaces, analog-to-digital converter), shielo material characteristics [Chemtree (a commercial !ead cement) and lead aggregate], and computer program coordination permitted LRL system construction to begin at Houston in July $1967 .{ }^{3}$ The LRL system was in operation within the year and mission ready for the first and subsequent simulations preceding Apollo 11 in July 1969.

Two technicians from NASA were assigned to the ORNL group for training, but one was replaced late in the program and there was a last minute staff change at NASA. As a result, the NASA operating staff was not ready at mission time. The group of four engineers from this Division that designed and installed the system was sent to the LRL to assist in operating the spectrometer for Apollo flights 11 and 12.4

Just prior to Apollo 11, the lunar sample containers (designed elsewhere) for use in the gamma-ray spectrometer proved defective and could $n \cdot t$ be used. This prevented mission-ready cerification. McKay and Sliski modified the existing storage hardware such that mission-ready certification was obtained. Subsequertly, they worked behind the tiological barrier at LRL, preparing lunar samples. From this experience, they leamed the unique procedures and enginee ring requirements for handling and storage of lunar materials.

During these missions this D vision established a continuing relationship with the LRL. As a result, the Division fulfilled several NASA contracts and currently has three contracts for spectrometer update, auxiliary system design and fabrication, ${ }^{5}$ unique sample containers, ${ }^{6}$ specialized tool production, and storage-transfer lunar material containers. ${ }^{7,8}$

In direct support of Apollo flights 15, 16, and 17,680 lunar material containers were delivered to the LRL. These containers will be used for short-term storage and shipping and long-term storage of lunar material.

The gamma-ray spectrometer siield was repaired in January 1972 because long-term foundation degradation caused extensive damage to the shield. A design was submitted to NASA LRL for foundation reinforcement.

A core-tube extraction tool was designed and built for the removal of a lunar core sample from its vacuum tube container. Heretofore, core-tube extraction was difficult and in some cases the samples were damaged. 
Subse yuent to the $\left.196^{\circ}\right)$ pre-Apollo 11 mission. this Division has maintaired a nore than 2-man-year assistunce to NASA.

1. V. A. Mekiy et al., "Protolype Low-Level (iamma-Ray Spectrumeter for the Lunar Receiving Laboratury." Instrumentation and Controls Div. Annu. Prugr. Rep. Sept. 1. 1967. ORNL.4219. pp. 49-52.

2. V. A. M-Kay, "Low-Radioxtivity (ans for Nal(Tl) Detectors." Instnurnentarion and Controls Div. Annu. Progr. Rep. Sept. I. I968. ORNL 4335 . p. 23.

3. R. F. Wintenbery et ad.. "Low-Level Gamia-Ray Spectrometer for the Lunar Receiving Laboratory," Ibid., p. 9.

4. R. E. Wintenberg et al., "Low-Level Gamma-Ray Spectrometer for the Lunar Receiving Laboratory," Instrumentation and Controis Div. Annu. Progr. Rep. Sept. 1, 1969, ORNL-4459, p. 5.

5. V. A. McKay and T. F. Sliski. "Lead Shield for LRL Spectrometer," Instnumentation and Controls Div. Anmu. Progr. Rep. Sept. I, 1970, ORNL-4620, p. 17.

6. V. A. McKay, T. F. Sliski, and H. J. Stripling, "Containers and Tools for In-Vacuo Processing of Lunar Marerial," Ibid, pp. 17-2I.

7. V. A. McKay and T. F. Sliski, "Containers for Lunar Materials." Instnumentation and Controls Div. Annu. Progr. Rep. Sept. I. 197I, ORNL-4734, pp. 88-89.

8. R. F. Wintenberg and R. T. Roseberny, "Engineering Support for LRL Radiation Counting Facility," Ibid., p. 3. 


\title{
4. Radiation Monitoring
}

\subsection{RADIATION MONITORING SYSTEMS DEVELOPMENT}

\author{
C. C. Hall J. L. Lovvom P. P. Williams
}

Facility Radiation and Contamination (FRC) Alarm Systems

An FRC system was designed for the ${ }^{233} U$ Storage Facility (Building 3100). The system consisis of two Q-4008 Criticality Monitor: and one Q-4303 Constant Alpha Air Monitor, a central alarm panel, and an evacuation horn. A visible and audible alarm will operate when the building containment system fails. Remote alarms from this system will be transmitted to the Radiochemical Processing Pilot Plant (Building 3019) and the ORNL Guard Headquarters (Buiding 2500). An intrusion alam system that will indicate an unauthorized entrance will be installed in the stcrage facility after construction of the facility is completed.

Design of a remote alarm panel for the FRC system in the Metals and Ceramics Laboratory (Building 4508) was started. The panel will be installed at the south entrance to the building and will display visible alarm signals received from an existing ceniral alarm panel.

The FRC system in the Solid-Siate I.sioratory (Building 3025) was modified by adding a module that operates the building containment system when the evacuation alarm is sounded.

The updated FRC system ${ }^{1}$ in the High-Radiation-Level Examination Laboratory (Building 3525) was completed and placed in operation.

A 24-V battery charger (Q-3140-1) was designed and built for the neutron-monitor, emergency standby batteries in the Metals and Ceramics Laboratory.

A mock-up to cetermine the most efficient frequency and noise level for FRC emergency evacuation signals is being testei at the MSRE facility (Building 7503).

\section{Local Air Monitoring System and Fallout Monitoring System}

A graphic panel was designed for each system. The panel is a Metal-photo map with three miniature incandescent lamps at each monitor location. The lamps will glow brightly when radiation levels at the monitor station exceed preset values.

\section{Effluent Waste Monitoring}

Engineering support was continued for the effluent waste monitoring operations of the Operations Division: equipment checks were scheduled, reports were reviewed, and the engineering drawings were corrected. A flow trayerse was started on the 3039 gaseous effluent stack to redetermine the true effluent flow rate.

1. A. L. Case et al., Instrumentation and Controls Div. Annu. Progr. Rep. Sept. 1, 197I, ORNL-4734, p. 79. 


\subsection{LOGARITHMIC COLNT-RATE METER}
F. .11. Glass
E. E. WE:
H. N. Wilson

A solid-state version of the Cooke-Yarborough !oganthmic count-rate meter was designed to con!tom to the nuclear instrument module (NIII) system. This new instrument (Q-3I23) was designed for the TVA Browns Ferny peiver plant. These instruments are companion modules to the Q-3020A linear count-rate module and ex end the range of the monitoring system to record transient excursions :well above the range ci the Q-3020A module.

The Q-3123 module covers a range from 10 to $10^{5}$ counts/min in tour decades, has good long-term stability, a low incidence of failure, and negligible calibration shift as a function of temperature over a range from 0 to $140^{\circ} \mathrm{F}$. The calibration procedure for this instrument is quite simple since no individual decade pump adjustments are necessary.

A count-rate test module (Q-3123-11) that generates three precision test frequencies at dec ade intervals was designed specifically for checking the caibration and logarithmic response of the Q-3123 inunt-rate module.

Four count-rate modules and one test module were fabricated and delivered to TVA.

\subsection{DIRECTIONAL GAMMA PROBE}

\section{J. M. Rochelle}

A directional gamma-radiation detector was developed and fabricated for evaluation by the Defense Civil Preparedness Agency in an application such as a survey of a fallout shelter to determine the direction of incoming radiation. The detector assembly was designed so that it conld be substituted directly for the standard CD V-700 probe assembly, thus requiring no modification of the instrument.

Directional gamma response is obtained by placing a small G-M counter (Amperex 18529) in the center of a 'ead sphere that is machined in sections to obtain in terchangeable apertures of 30,90 , and 181$)^{\circ}$. The front-to-back shielding ratio obtained with a 3 -in.-diam sphere is about $7.3\left({ }^{60} \mathrm{Co}\right)$. The total weight (lb) of each sphere assembly is

$\begin{array}{cc}\begin{array}{c}\text { Aperture } \\ \text { (deg) }\end{array} & \begin{array}{c}\text { Total Weigl.: } \\ \text { (lb) }\end{array} \\ 30 & 6.8 \\ 90 & 6.2 \\ 180 & 4.4\end{array}$

\subsection{ADVANCED AERIAL RADIAC STUDY}

\section{R. L. Shipp V. A. McKay}

A study of possible techniques for high speed, high altitude measurement of ground level nuclear-radiation intensities associated with fallout was started. The objective is to measure a dose rate range from 0.1 to $10.000 \mathrm{R} / \mathrm{hr}$ with a 500 -ft-diam resolution from an aircraft at an altitude from $\mathbf{0} 0.000$ to $50,000 \mathrm{ft}$ and at a speed of Mach 2. This work is being done for the U.S. Army Signal Corps.

Since geometric factors. air attenuation, and scattering of gamma radiation over a path of $10.000 \mathrm{ft}$ or greater in air prevent direct acrial measurement of ground-level radiation intensity patterns. a more immediate objective is to develop (1) a way to detect radiation effects on the environment and 12 ) dose-rate measuring devices which could be dispersed over a fallout zone and read from an aircraft. 


\title{
4.5 ENGINEERING ANALYSIS OF THE CD V.7II SHELTER MONITOR
}

\author{
F. M. (ilass
}

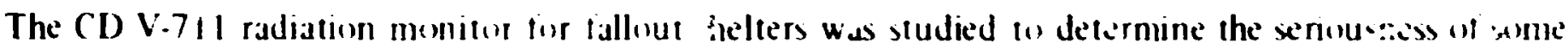
of the complaints on the performance of this instrument and lo recommend ihanges to improve its operating charactenstics. We found several weaknesses in the basic circuit design that idased pour performanci. The calibration changed drastically with changes in hattery voltage. This reduced the useful life of the battery as well as the ero and calibration stability of the extent that the instrument was unacceptable. The built-in sircuit check did not include the high-impedenic ciacuit and was therefore inadicquatr.

we re:ommend a minimum $n$ mber ot dircuit hanges in the monitor that would extend the batten iite to 320 ir of continucus aperation with a shift in . Ibration of only $3 \%$. We also offered an alternative proposil that inciuded substitution of a solid-state circuit in the instruments on händ.

\subsection{AIR FLOW MEASUREMENT IN THE 3039 STACK}

\section{H. J. Het}

\section{G. W. Allii D. J. Knowles P. P. Williams}

A new determination of the velocity profile at the 50-it level in the 3034 stack was requested by the Operations Division. Last done in 1961. such a profile is necessary for verification of both the accuracy of the total flow, as indicated by the permanently installed velocity sensor, and the sounaness of the design and placement of the stack effluent samplers. Sampl's are withdrawn from the stack for continucus monitoring, and samples are also taken from the stack stream for later laboratory analysis.

To make this profile measurement. additional tlanged openings were cunstructed in the stack at the j0-it level, and three wre-rope cables were stretched across the stack diame:er at equal angular intervals. vertically spaced I it apart. The gas velocity sensor will be suspended from the cables so that profile traverses can be made routinely.

The flow velocity in the stack is $5.10 \mathrm{ft} / \mathrm{sec}$, a difficult to measure region. A tluid jet type flow sensor was ordered and sent to the Nationa. Buriau of Standards (NBS) for verifica ion of the calibration curve. The device was eliminated for this use whon the NBS was unable to duplicate the vendor's calibration curves. A ho:-wire aneinometer was tried, but, because of the extreme turbulence at this level in the stack. andysis of the data obtained with this sensur has proved difficult. A propellor-type anemometer is being considered as a sensor to complete these measurements.

\subsection{IODINE MONITOR IMPROVEMENTS}

\section{G. W. Allin}

At the ORNL central radioactive gas disposal facilities, an iodine monitor that is cquipped to enable changing the charcoal filter material remotely' frequently failed to operate because of blockages in the charcoal feed tube due to moisture from condensation and bridging characteristics of the matcrial. An insulated enclosure, a small electromagnetic vibrator, and a small thermostatically controlled space heater were added to reduce the likelihood of such hlockages. The system has operated for about a year without further blockage. $3 !$.

!. (;. H. Allin. "Iodine Monitor," Insinumentathon and Conerols Div. Annu. Progr. Rep. Sep: 1, 1968, ORNL-4335, p. 


\title{
5. Support for the Oak P.idge Electron Linear Accelerator Development
}

\section{5.! MMPROVEMFNT PROGRAMS}

\author{
T. A. Lewis
}

The continuing program of improv'sment' of the ORELA progressed favorably. Improvement of the inje:tior system electronics was completed, and this unit has performed in a highly successful manner: corıbined with the high voltage modulator improveme its. a new record in high-power reliability was establishe,l for ORELA at a beam levei of $50 \mathrm{~kW}$.

Studie; to improve the electror gun performance and ine peak current accelerated in a 3-nsec burst by prebuachi ig schemes have progressed favorably and are continuing.

1. T. A Lewis. Instrumentation and Controls Dir. Anmu. Prozr. Rep. Sept. 1. 1971, ORNL-4734. p. 24.

\section{S.2 ELECTRON INJECTION SYSTEM IMPROVEMENTS}
J. H. Helladay
G. W. Allin
C. C. Courtney
W. E. Lingar
E. E. Waugh
H. N. Wilson

An impr sved electron injection sysiem was installed. ${ }^{1}$ The system is operating satisfactorily. Downtime for the accelcrator was reduced considerably because of increased reliability of the system. Also, conversion to a modular sys!em enables subsritution of reliable spare modules while defective modules are repaired. $\mathbf{A}$ test stand simulator was fabricated so that all spare electronic modules can be repaired and checked under conditions similar to those in the operating system except that the test stan. 1 is not under pressure.

The new 54-in.-diam pressure vessel meets all requirements of Sect. VIII of the ASME Boiic: ard Pressure Vessel Code. The ORNL designed, quick-opening closure clannp ring with two screws at each joint can be removed easily using integral devicis to gain access to the internal electronics haraware.

Occasionally. solid-state components had been damaged by voltage transients due to arcing in the secondary of the isolation power transformer that feeds power to the injection system. To reduce the efiects of voltage transients, glow discharge devices in connection with inductors, forming a pi network, were inse' ted into the incoming power lines.

Recently developed power transistors that can switch high energy levels were installed in the switching regulator of the power supplies. The inverter that drives the output transformer of each power supply was designed as a two-transformer type. A large pow'r transformer changes voltage and current levels linearly, and a smaller saturating transformer controls the inverter switching frequency. The saturating transformer windings are on a tape-wound toroid. and the turns ratios can be easily modified to change the inverter switching frequency.

1. J. H. Holladay et al., Instrumentation and Controls Div. Annu. Progr. Rep. Sept. 1. 1971, ORNL-4734, p. 24. 


\title{
5.3 ORELA ENGINEERING DEVELOPPMENT SUPPCK I
}

\author{
J. H. Todd
}

General engineering support was giver: to development an 1 tests of improved subsystems on the accelerator. along with routine maintenance support.

Test instruments were designed and built for repair of the accelerator fosusing supplies. These units supply power and switched input signals to the various modules and subsy'stems, enabling rapid location and repair of faults. Most of these modules and subsystems are used in feedback control systems where troubleshooting is difficult.

Assistarice was given to testing a new gun tank that is mounted and in use on the accelerator.

Design of a new logic and iming system to increase the reliability and flexibility of operation of the accelerator was completed, and its cons:ruction was started.

\section{S.4 ELECTRONIC SERITESS FOR DRELA}

\section{H. A. Todd}

Changes were made to thz OREL's when operating experience showed some trouble points of questionable reliability. High voltage feedthroughs were installed to feed high-voltage pulses from the modulators into the klystron oil tanks, and the cab!es carrying these pulses were rerouted and shortenec Additional cooling was added to all moduiators. Scla transformers were installed to regulate the voltage to all thyratron filaments and reservoirs in che modulators.

The ORNL-designed injector tank ivas insta'led on the accelerator, and the old injeitor tank was set up outside the accelerator fir testing and processing new electron guns. This arrangement eliminates the previous necessity to stor sccelerator operation for several days while a new gun was being processed (raised to high voltage speration) in the accelerator.

\subsection{NEUTRON FILTER ASSEMBLY SYSTEM}

$$
\text { R. W. Ingle }
$$

During the past year two additional neutron beam tubes were placed in operation by the Neutron Physics Division. These beam tubes in flight paths four and eight required vacuum control and neutron filter assemblics similar to those ref, ,rted. ${ }^{1,2}$

Each system consists of a vacuum-protection valve, beam stopper, and ten separate neutron filter mechanisms, all mounted wititin the beam tube which is under vacuum during operation. Each device is pneumatically operated by an electric solenoid value controlled from an experimental laboratory. The solenoid for control of the vacuum valve is opersted by $115 \mathrm{~V}$ ac and is electrically in series with a vacuum differential sensor that prevints the valve from being upened until the pressures on both sides of the valve are equalized. This interlo:k is a safety protection device for both personnel and equipment.

The neutron filter units were mounted such that each or any combination can be inserted or withdrawn from the neutron bear. These valves and the valve in the beam stopper are operated by $24 \mathrm{~V} \mathrm{dc.}$

The control unit consists of a 28-V, 19-A power supply, an indicating and control panel, and printed circuit cards containing control and solenoid drive circuits. The cuntrol panel has indicators that show the position of each! unit and toggle switches that control the position. The beam-stop and filter solenoids are driven from a iwo-tian. :tor driver circuit that supplies the $24 \mathrm{~V}, 800 \mathrm{~mA}$ power for operarion of a solenoid. Eleven ideritical circuits are contained on orie printed circult card. The input to the driver is either 
+ $5 \mathrm{~V}$ or ground. depending on the position desired. This input may be either from the manual-control toggle switch or from a TTL storage register, which is to be operated by pulses from a digital computer. The present mode of control is manual operation.

1. R. W. Ingle et al., Instnimentation and Controls Div. Anmu. Progr. Rep. Se 1. 1. 1969, ORNL 4459, pp. 3637.

2. R.W. Ingle, Insrrumentation and Controls Div. Annu. Progr. Rep. Sept. I. 1971. ORNL-4734, pp. 27- 28. 


\title{
6. Automatic Control and Data Acquisition
}

\subsection{DATA ACQUISITION SYSTEM FOR THE FFTF TEMPERATURE SENSOR EVALUATION FACILITY}

\author{
R. F. Hyland \\ K. R. Carr \\ J. T. Hutton \\ J. M. Jansen, Jr. \\ C. D. Martis, Jr. \\ I. L. Redford
}

Installation of a new data acquisition and control system for the Fast Flux Test Facility was started to allow a more comprehentive testing program to be carried sut. The system will consist of a PDP-8/E computer with a $12 \mathrm{~K}$ core, $32 \mathrm{~K}$ disk, programmable real-time clock, power-failure protection, boosstrap loader, 12-channel buffered digital input-output extended arithmetic unit, and high-speed paper-tape reader and punch.

Capabilities of the system will include automatic programmed calibration of a variety of temperature sensors, computer control of up to 12 furnaces, transient response studies, loop resistance measurements, programmable amplifier gain, programmable suppression, and integrating or successive approximation, analog-to-digital conversion.

The software system will be based on the real-time executive program ${ }^{1}$ which is being modified extensively to accommodate tasks written in the FOCAL language as well as tasks written in assembly language. This will enable project engineers to develop special test programs on-line in a short time, a capability which should greatly enhance the effectiveness of the data acquisition system.

1. C. D. Martin, Jr., Instrumentation end Controls Div. Annu. Prog. Rep. Sept. 1, 1971, ORNL-4734, p. 42.

\subsection{DATA ACQUISITION SYSTEM FOR THE FAILED-FUEL MOCKUP TEST FACILITY}

$$
\begin{array}{lll}
\text { C. D. Martin, Jr. J. M. Jansen, Jr. G. B. Raine } &
\end{array}
$$

Transient experiments in the FFM test facility will require a digital data acquisition system capable of scanning, digitizing, and recording test parameters on magnetic tape at the rate of 10,000 readings/sec for periods of several minutes. A system was designed to fulfill these requirements, comprising a small digital computer (PDP-8/E), solid-state multiplexer, programmable gain amplifier, analog-to-digital converter, and industry compatible magnetic tape.

System programming will make available to the experimenters the FOCAL language, a high-level intere rtive !anguige, which will permit instant, on-site program changes by projec! engineers to tailor the data scquisition task to the needs of the particular experiment. The system will be capable of preliminary data rec. -tion on-site after an experiment and display of data for immediate determination of experimental results. Such inımediate analysis will be required for adequate direction of the experimental program because of the expense and time required to set up and run an experiment. The ORNL Computing Center will perform a detailed analysis of selected experimental data.

\footnotetext{
1. Mathematics Division.
} 


\title{
6.3 DATA ACQUISITION SYSTEM FOR HIGH TEMPERATURE THERMOMETRY LABORATORY
}

\author{
R. F. Hyland J. L. Redford
}

A system is being irstalled to acquire steady-state and transient data from a high-temperature thermometry test facility consisting of furnaces with power and control equipment. This facility will be used for the development and calibration of high-temperature sensors and for studying the transient characteristics and long-term drift of the sensors.

The data system consists of a PDP-8/E computer with $8 \mathrm{~K}$ of core memory, power failure detection, teletypewriter, high-speed multiplexer for low-level analog signals, data amplifier, analog-to-digital converter, a.gital-to-analog converter, multiple contact inputs and outfuts, and a $10-\mathrm{Hz}$ real-time clock. Most of the peripheral devices wil! be obtained from the FFTF Temperature Test Facility' when a new data acquisition and control system is instalied in that facility.

1. R. F. Hyland and B. G. Eads, Instrumentation and Controls Div. Annu, Progr. Rep. Sept. 1, 1970, ORNL-4620, Pp. 41-42.

\subsection{MINIATURE COMPUTER SYSTEM FOR THE GEMSAEC FAST ANALYZER}

$$
\text { J. M. Jansen, Jr. }
$$

A portable, computer-based data acquisition and analysis system was designed and supplied for the GeMSAEC clinical analyzer. This system is a miniaturized, inexpensive version of the system previously decribed. ${ }^{1,2}$ The equipment consists of a PDP-8/E computer with 8192 words of core memory, a 120-Hz line-frequency-based clock, a model ASR-33 teleprinter-keyboard, and analog and digital interfaces ${ }^{3}$ for couping the GeMSAEC analyzer to the computer hardware.

The system was designed to acquire data from GeMSAEC analvzers with rotors containing 1 to 43 cuvets operating at speeds from 100 to $2000 \mathrm{rpm}$. Analog input voltages are converted to digital values by a successive-approximation, analog-to-digital converter with an accuracy of $\pm 0.5 \%$ of full scale $(-10 \mathrm{~V})$.

The high-level language FOCAL was modified and extended with appropriate software to accept data under real-time contrcl of the line-frequency clock. Modified subprograms were added to enable program and data storage on and retrieva! from a digital cassette tape unit. Direct-access features of the tape transport enable storage oi data from many analyses for later correlation and study, as well as reprocessing of the original data with new data processing techniques.

1. J. M. Jansen, Jr.. and R. K. Adams, Instrumentation and Controls Div. Annu. Progr. Rep. Sept. 1, 1969, OR NL.4459, P. 49.

2. J. M. Jansen, Jr., and J. L. Redford, Instrumentation and Controls Div Anmu. Progr. Rep. Sept. 1, 1970, ORNL.4620, p. 54.

3. James M. Jansen, Jr., “A Computer Interface,” U.S. Pat. 3,565,116 (A pril 11, 1972).

\subsection{DATA ACQUISITION SYSTEM FOR TURF DEVELOPMENT LARORATORY}

\section{J. M. Jansen, Jr. \\ J. T. Hutton C. D. Martin, Jr. H. E. Cochran}

A small, digital computer system consisting of a PDP-8/E computer with 8K words of core memory and an ASR-33 teleprinter-keybcard was irstalled in the Thorium-Uranium Recycle Facility. The computer is interfaced to a digital voltmeter and a microscope eye-piece counter through a universal BCD instrument interface (Sect. 6.8). The system is operated in the high-level language FOCAL, which was modified to 
control the $\mathrm{BCD}$ instrument interface for manipulation and readout of the digital voltmeter and for readout of the counter. Additional FOCAL software was prepared for cperation and readout of input-output receivers and transmitters.

Application software packages were prepared to measure particle diameters and the coating thicknesses of cuated microspheres from radiomicrographs of the coated particles. The computer prints the mean. standard deviation, and $95 \%$ confidence limits of the measured parameters. Soitware programs were also developed to measure the crushing resistance of the coated particles.

All operator and computer software communication is performed through several switches and indicators connected to the input-output interfaces.

\subsection{EXPERIENCE WITH DEXTIR DATA ACQUISTTION SYSTEMS}
R. F. Hyland
R. M. Burnett
J. W. Cunningham
R. L. Durall
C. D. Martin
O. W. Russ ${ }^{1}$

This system at the Oak Ridge Research Reactor completed another year of continlious operation, gathering data from uranium nitride cupsule experiments UN-4, -5 , and -6 and from fuel-cladding mechanical interaction experiment MINT-I. Processing of data for the UN capsules is essentially unchanged from that previously reported. ${ }^{2}$ The MINT-1 capsule instrumentation measures fuel dimension, pressure, and temperature. The data reduction equipment calculates and plcas the cladding temperature, fuel elongation, cladding expansion, and capsule pressure on a common time base.

At the High Flux Isotope Reactor, fueled capsule experiment HRB-3 was installed in facility HB-5, and the DEXTIR system gathered data continuously from this experiment. At the end of each reactor cycle, a plot produced at the central computer from DEXTIR data correlates reactor power capsule position, temperatures, pressures, and flow rates for that cycle.

$W-3 R e$ vs $W-25 \mathrm{Pe}$ thermocouples were used to measure the centerline fuel temperature in the capsule. The performance of these thermocouples was determined by loop-resistance measurements ${ }^{2}$ which utilize the multiplexing speed of the data system to avoid Peltier heating of the thermosouple junction.

The system in the Reactor Design and Engineering Development I Building 9201-3 continued to acquire data from Reactor Division experiments. The Failed Fuel Mockup input was expanded 75 channels, and the computer program was modified to list the additional channels with unique headings on a ser.ond teleprinter at the test locations.

New experiments connected to the system were a thermal transient (Hot TEE Section) test, a heat block test, and a weldment creep rupture test facility.

Acquisition of data was continued from the forced-convection corrosion loops and organic-fluid decomf sition tests.

1. ORNL Mathematics Division.

2. R.F. Hyland et al., Instrumentation and Controls Dw. Annu. Progr. Rep. Sept. I, 1971, ORNL-4734, pp. $37-38$.

\subsection{FOCAL COMPUTER PROGRAM FOR WIRE LIST GENERATION AND MAINTENANCE}

\section{J. T. Hutton J. M. Jansen, Jr.}

Keeping a correct and complete wire list for an interface under rievelopment is troublesome, and sometimes the lists prepared sre unreliable. A FOCAL computer program was prepared that makes the maintenance of correct wire lists relatively easy and also allows access to the wire list at a high enough level 
to be of use in development and troubleshooting. The program implements the following operations on a wire list: addition of wires: deletion of wires: listing of all wires connected to a point or range of points: tree format listing of all points with continuity to a given point: and listing an entire wire list and punching the wire list on eight-level paper tape. The FOCAL program will handle wire lists of up to 1368 wires and utilizes 4096 words of disk storage.

\title{
6.8 GENERALIZED HARDWARE-SOFTWARE INTERFACE PACKAGE FOR INSTRUMENTS WITH BCD OUTPUTS
}

\author{
J. T. Hutton J. M. Jansen, Ir.
}

Most instruments, such as voltmeters, frequency counters, and analog-to-digital converters, to be interfaced to general-purpose computers have basically simiiar BCD outputs. The voltage and impedance levels vary, but the format is essentially the same from instrument to instrument. A generalized interface package for use with PDP-8/E computers was designed to take advantage of this commonality and thus save a large part of the expense in design and development of separate interfaces for each type of instriment.

Tire interface is driven thro'sh a special FBCD function in the FOCA: language which allows function, range, and (where applicable) integrate period to be specified for up to eight different instruments. The FBCD function returns the instrument readings in standard floating-point format or indicates that the function, range, or integrate period specified for a particular instrument was invalid.

The hardware of the package comprises a master board which plugs into the omnibus of the computer, up to eight communicator boards, and associated level converter boards. The master board interfaces to the computer input-output and data bus system and services the communicator board inputs on a user-assigned priority basis. The communicator boards are basically parallel to serial converters that transmit the BCD digits back to the master board on demand. The level converter boards take care of data inputs to the communicator boards that are not at standard TTL levels and also check that the requested ranges, functions, and integrate periods are correct for each particular instrument. The communicator and level converter boards are mounted in a modified NIM type bin to allow straight-forward expansion of the package as additional instruments are added to the system.

\subsection{CONSOLIDATED PDP-8/E IN TERPACE FOR CONTROL OF SEVERAL HIGH-PRECISION ANALOG INPUT STSTEM CONPONENTS}

\author{
J. T. Hutton K. R. Carr \\ R. \&. Hyland J. M. Jansen, Jr.
}

Since the combination of crossbar scanner, voltage suppression supply, programmable-gain instrumentation amplifier, and analog-to-digital converter is part of one data açuisition system after another, a PDP-8/E interface was designed that wil accommodate any or all of these components.

The interface enables random access to 1024 crossbar scanrier channels, insertion of positive or negative suppression to $10 \mathrm{~V}$ in $0.01-\mathrm{V}$ increments or to $100 \mathrm{mV}$ in $100-\mu \mathrm{V}$ increments, selection of any of ten amplifier gains, and digitizing of signal witi: either a fast $1 \%$ bit successive approximation type analog-to-digital converter or a slower 14-bit inte;rating type analog-to-digital converter. On completion of reading the signal at a selected channel (with recuired delays for settling of amplifier, etc., automatically inserted), the interface returns the result as a 24-bit two's complement number.

To ensure short-term systeri accuracy, joth the 16-bit digital-to-analog converter used in the suppression unit and the 14-bit anaiog-to-digita converter are mounted in temperature controiled modules. 
Long-term accuracy will be maintained by periodic calibration of the amplifier, digital-to-an?'og converter, and analog to-digital converter.

\subsection{U PAPER-TAPE PUNCH CONTROLLER T:OR DIGITAL STRAIN INDICATOR SYSTEM.}

\section{J. T. Hutton}

Several digital strain indicator systems comprising strain-gage channel selector units, a null balancf:readout unit, and a digital printer are used by the Reactor Division. A paper-tape punch controller w.ts designed for a demand punch so that data from the null balance-readout unit could be punched seridity in paper tape (for subsequent computer processing) without interfering with data output on the digita' printer. Since data and conirol lines from the digital strain indicator were at several different voltage levels $(+10 \mathrm{~V},-43 \mathrm{~V},+150 \mathrm{~V}$, etc.) and carried high-frequency transients from relays and solenoids, we buffered all lines into the logic circuits of the punch controller through low-Fass comparators. The comparator circuits have inexpensive $\mu \mathrm{A} 747$ operationai amplifiers, and the logic circuits have SN7400 series TTL integrated circuits. The punch controller proved reliable in regular use for more than six months.

\subsection{CHANNEL DATA LOGGER FOR THERMOCOUPLE CALIBRATION}

\section{J. T. Hutton R. B. McFarland}

A data logger for calibration of ORNL Stores Stock thermocouples was designed and fabricated, largely from instruments and parts of two retired data systems. The logger consists of a crossbar scanner, 11-bit anaiog-to-digital converter, paper-tape punch, and control logic. The logger will be used instead of the present manually operated potentiometer-galvanometer system and will result in faster and more relizble accumulation of the temperature data.

\subsection{USAGE OF SMALL-COMPUTER APPLICATION DEVELOPMENT FACILITY}

\section{J. L. Redford}

Short-term studies of the behavior of thermocouples and resistance thermometers (RTD) under transient conditions were made with a PDP-8/1 computer in the Small-Computer Application Development Facility ${ }^{1}$ of this Division.

One study was to determine the effect of insulation quality (compaction, composition, etc). of $1 / 8$-in.-OD, stainless steel sheathed, MgO filled, Chromel-Alumel thermocouples from various manufac. turers. The sheath of a short specimen oi a thermocouple was heated at varying rates $\left(2\right.$ to $\left.200^{\circ} \mathrm{C} / \mathrm{sec}\right)$ by passing current through the sheath and observing the temperature of the thermocouple wire (as inferred from change in resistance). The use of FOCAL language and a storage oscilloscope plotter in the facility allowed the experiment to be set up and conducted with ease.

In another study two RTD's were assembled in a single $1 / 4-$ in.-CD sheath, the oual unit was heater in a rest furnace, and the resistances of the two elements were cumpared at fixed time intervals as the funnace was heated to $\sim 1600^{\circ} \mathrm{F}$ and ther cooled. After an apparent annealing on the first heatup, the elements were within manufacturers' specifications on all subsequent tests. The data were plotted on the storaye oscillnscopes and recorded on tafe cassettes. To improve the sccuracy of the analog-to-digital converter in the system, suppression (supplied by the digital-to-analog converter) was utilized.

1. R. K. Adams et al., Instrumentation and Controls Div. Annu. Progr. Rep. Sept. 1, 1970. ORNL-4620, pp. S1-52. 


\title{
6.13 DEVICE HANDLER FOR MAGNETIC TAPE
}

\author{
J. M. Jansen. Jr. G. R. Raine'
}

A device handler program that occupies oniy a single page ( 128 words) of memory and allows use of an IBM-compatible magnetic tare in a manner similar to DEC cape was prepared for use with DEC PS/8 and OS/8 programming systems for the PDP-8/E computer. All PS/8 and OS/8 functions are possible, and the devise handler was edited into the O tober 28,1970 , version of CONFIG, the FS 18 system configurator. The subroutine handles up to four magnetic-tape transports, addressable as devices MTAÚ, MTA1, MTA2. and MTA3. The magnetic-tape device handler replaces the DEC tape handler which addresses devices DTA4, DTAS, DTA6, and DTA7.

The handler $\mathrm{F}$ rovides parit, , length, and timing error checking on each block of 256 words and on block number records. In case of error, the read-write operation is reattempted a maximum of two additional times before the fatal error exit is taken.

A tape formatting program, permitting 512 blocks of 256 words, was prepared to correctly format the magnetis tape for use with the MTA a ddressable handlers. Thus, the advantages of the preaddressed, blocked DEC tape data format are combined with the compatibility of IBM data recording.

The subroutine was designed for use witl: a PERTEC Model 6840 tape transport interfaced to a PDP-8/E with a DATUM Model 5091-P8je coniroller. The DATUM cortroller is very similar to the DEC Medel TC58 controller, making necessary only rinor changes in the device handler software as written for use with the DEC TC58 controller.

1. Mathematics Division.

\subsection{STATUS OF WALKER BRANCH WATERSHED DATA ACQUISITION SYSTEM}

\author{
$\begin{array}{ll}\text { J. T. Hutton } & \text { R. L. Sim pson } \quad \text { C. D. Martin, Jr. }\end{array}$
}

Design and fabrication of the computer-based dat:a acquisition system ${ }^{1}$ was completed, and the system is currently being installed. The system will initially acquire data from nine instruments, five precipitation gages, and four stage-height recorders to correlate rainfall and runoff by time and geographic location in the watershed. The computer, running under the disk-based, real-time executive program, ${ }^{2}$ will periodically interrogate each of the instruments to obtain current data. Data requests will be sent from the computer to a central field station at the watershed orer a pair of telephore lines by frequency-shift telemetry. The central field station will decode the number of the gage being interrogated and relay the request for data to the particular gage ovei ijata lines to that gage. The gage will send the required data back to the computer over a second pair of 1:lephone lines that will serve as a party line to all gages. Al: ielenhone and data lines will be cornected to tíe system through optiral isolators to give protection against high-voltage transients caused by lightnins. Some preliminary processing will be done on data before they are recorded on magnetic tape for further processing at the ORIN computing center.

1. C. D. Martin. Jr., and R. K. Adams. Instrumentation and Cortrols Div. .4nmu. Progr. Rsp. Sept. 1, 1971. ORHL-4734, pp. $126-27$.

2. C. D. Martin, Jr., Ibid., p. 42. 


\subsection{5 $180^{\circ}$ ORSIS COMETER SYSTEM}

\section{j. M. Jansen. Jr. W. K. Dagenhart'}

The system, previously described, ${ }^{2}$ was expanded to provide additional flexibility in more sophisticated control applications with the $180^{\circ}$ Oak Ridge Sector Isotope Separator. The computer system was implemer $\mathrm{d}$ by adding a second, 32K-disk-memury storage device and a universal digital input-output controller for operation of relays and relay drivers and readout of contact and switch closures. Software was added to the FOCAL system to enable use of both disks for program and data storage. The original contact input-output software was modified to operate all of the digital input-output drivers and receivers. Th:c error handling procedures for failures in conversion of the analcg signals to digital format were refined to increase the overall effectiveness of the system in real-time, continuous control of the separator. Preparaiiori of estimates for expansion of the system to control an additional separator was started.

R. K. Adams and J. M. Jansen, Jr., participated in a committee study of computer control of Calutron separators for the Electromagnetic Separations Department of the Isotopes Division. The Committee concluded that computer control of the separators was feasible, but detailed studies of the separation process would be required to develop a suitable computer control system.

1. Isotopes Division.

2. A. H. Voelker, Instrumentation and Controls Div. Annu. Progr. Rep. Sept. 1, 1970, ORNL-4620, p. 45.

\section{I6 AUTOMATED ELECTROCARDIOGRAM DATA ACQUISITION SYSTEM}

\section{R. L. Simpson}

Continued support was given the Automated Electrocardiogran Data Acquisition System.' At the end of each working day, the analog tapes were rerecorded and digitized on IBM-compatible magnetic tapes which were delivered to the ORNL Computing Center for analysis using the Mayo Clinic program. This past year, more than 3000 EGG's from routine ORNL employee screening tests were digitized and analyzed. The equipment was main!oined by personnel from this Division.

1. A. H. Voelker, A. S. Garrett, h., M.J., and R. L. Simpson, Instrumentation and Controls Dí Annu. Progr. Rep. Sept. 1, 1971, ORNL-4734, pp. 132-33.

\subsection{CODAS SYSTEM PROGRAMMING}

\section{R. L. Simpsor:}

Continuing use of the Metals and Ceramics Division CODAS system ${ }^{2}$ required three program modifications as follows:

1. The program for writing magnetic tape in the system was modified to accommodate logic changes made in the controller for the magnetic-tape transport.

2. The function for calculating temperature using a Pt vs Pt-10\% Rh thermoroupla was changed from the IPTS-1948 to IPTS-1968.

3. A new command was added to change from using a Pt vs Pt-10\% Rh thermozoupie function for calculating temperature to a Chromel-constantan thermocouple function where apriicable.

1. J. M. Jansen, Jr.., and C. D. Martin. Jr. Sistrumenlation and Controls Div. A'.nu. Frogr. Rep. Sep:. I, 1971. ORNL-4734, p. 39. 


\title{
6.18 PROGRAMMING FOR STRESS LABORATORY DATA ACQUISITION SYSTEM
}

\author{
R. L. Simpson
}

An additional magnetic-tape unit was installed on the high-speed. strain-gage-oriented. computer-based data acquisition system used in the ORNL Stress Laboratory.' With this unit. the systerim an he reprogrammed to record processed data on magnetic tape. Previously only raw data were recorded on magnetic tape: processed data were punched on paper tape by the console teletypewriter. The mudified system can convert raw data to engineering units and record them approximately 100 times faster than previously. The magnetic tape produced can be read on the IBM 360 computer for further data reduciion or for listing on a line printer, or the taped data can be read back by the data acquisition system and listed on the teletypewriter.

1. R. L. Moore, T. M. Caie, and C. D. Martin, Insmumentation and Controls Dir. Annu. Progr. Rep. Sept. 1, 1971. ORNL-4734, p. 36.

\subsection{MULTISTAGE PROCESS COMPUTER CONTROL STUDIES SYSTEM PROGRAMMING}

$$
\text { C. D. Martin, Jr. }
$$

The PDP-8/I computer in the muitistage process computer contro! s'ucies system ${ }^{1}$ was replaced with a PDP-8/E computer with auxiliary disk memory. This change enabled application of the disk version of the real-time executive ${ }^{2}$ to increase the system capability. System tasks programs were modified to utiiize the disk for data and control parameter storage, and the direct digital control algorithm ${ }^{3}$ was rewritten to take advantage of the double precision operations available in the extended arithmetic element of the PDP-8/E.

1. C. D. Martin, Jr., et al.,Instrumentation and Controts Div. Annu. Progr. Rep. Sept. 1, 1970. ORNL-4620. pp. $45-46$.

2. C. D. Martin, Jr., Instrumentation and Controls Div. Anmu. Progr. Rep. Sept. I, 197I, OR PL-4i34, p. 42.

3. R. K. Adams and C. L. Partäin. Instrumentation end Controls Div. Anmu. Progr. Rep. Sept. 1, 1368, ORNL-4335. pp. 44-.45.

\subsection{PORTABLE, STRAIN-GAGE-ORIENTED DATA ACQUISITION SYSTEM}

\author{
C. D. Martin, Jr.
}

A sn.all: portable, strain-gage-oriented, computer-based data acquisition system was acquired iy the Reactor Division for use on several projects. The system consists of a Data General Nova 1200 computer with a $4 \mathrm{~K}$ core memory and $10 \mathrm{~K}$ drum memory, 120-channel solid-state multiplexer, strain-gage signal conditioning, programmable gain ampliîer, 15-bit integrating analog-to-digital converter, teletypewriter. and digital display. The integrated system included SYSTEM 70 software by DATUM, Inc.

Assistance was provided in checkin', out the system and applying it to the Intermediate Vessel Test series in the Heavy Section Steel Technology program.

\subsection{MISCELLANE' JS ECOLOGICAL FIEI.D STUDIES}

\section{J. L. Redford C. D. Martin, Jr.}

An additional 40 thermistor temperature probes were insta.'ed in the ORNL Liriodendron Forest, ${ }^{1}$ and assistance was provided in troubleshooting equipment failures in the data acquisition system. Since the data acquisition requirements exceed the capability of the present system, a small 200-channel computer-based data acquisition system with magnetic tape output was purchased and is heing instalied. 
The 10-channal. high-speed data acquisition system ${ }^{2}$ in the Instrument Laboratory (Building 3500) was used to digitize and record (via telephone lines) turbulent wind velocities measured by a sonic anemometer located in one of the ecology field study areas.

1. J. L. Redford, Instrumentetion and Controls Div. Annu. Progr. Rep. Sept. 1. 1971. ORNL-4734, p. 124.

2. R. F. Hyland. J. D. Burke, and R. K. Adams, Instrumentation and Controls Div. Annu. Progr. Rep. Sept 1, 1967. ORNL-4219. p. 58.

\title{
6.22 INTERACTIVE GRAPHICS PROGRAM FOR THE PDP 10-AD4 HYBRID COMPUTER
}

\author{
S. M. Ideli' R. S. Booth \\ O. W. Burke C. K. Johnson ${ }^{2}$
}

Crystal structure drawings by computers are used routinely for illustrating crystallographic articles in scientific journals. Computer programs such as ORTEP $^{3}$ for this purpose generally operate in a batch-job computing environnent and require siveral sequential runs on the computer with small changes between jobs to produce an acceptable drawing. A conventional interactive graphics terminal such as the PDP 10 PDP 15 - GRAPHICS 15 system in the ORNL computing center has turn-around time limitations that prevent a successful implementation of ORTEP as an interactive program: however, implementation cn the PDP 10 - AD4 liybrid computer does seem feasible if a storage oscilloscope is used. The analog portion of the proposed interactive CRTEP program is working and contains an ellipse generator, a line generator, and three circuits for overlap correction (i.e., hidden line elimination). The overlap correction is used to blank out the portions of atoms or interatomic bunds (represented by ellipses or iines) whici: are hidden betind up to three sther elliptical atoms or bonds.

1. Summer participant (1972) from the City College of New York.

2. Chemistry Division.

3. C. K. Johnson, ORTEP: A Forten Thermal - Ellipsoid Plot Program for Crystal Structure Illustrations, ORNL-3794, Rev. 2 (June 1965).

\subsection{APPLICATION OF ON-LINE COMPUTER DATA SYSTEMS TO EXPERIMENTAL DESALINATION PLANT ANALYSIS}

\section{S. J. Ball \\ J. L. Redford N. E. Clapp, Jr. J. G. Delene ${ }^{1}$}

Computerized data systems were designed for two experimental desalting plants: a three-stage flash evaporator at the Office of Saline Water (OSW) Wrightsville Beach (N.C.) Test Facility (WBTF), and a new hybrid evaporator plant to be built in Orange County, California. The purpose of these data systems is to facilitate the operation, testing, data collection, and analysis of plant behavior which will lead to a better understanuing of the processes and improved future designs. The WBTF jystem was installed in February 1972 and immediately operated to calibrate plant instrumentation, analyze plant performance, run a variety of experiments, and print summary reports. The Orange County data system was cesigned and ordered.

Most of the programming for these systems utilizes an expanded version of FOCAL, which is an algebraic interpretive language. Since the programs do not need to be compiled or assembled, the execution of a program can immediately follow a program modification. This language has proved ideal for routine data acquisition and analysis which doc 3 not require excessive processing speeds.

A program for evaporator frequency response testing (which does require processing at a higher speed) was developed for the on-line computer, using a combination of FORTRAN and asse:nbly-language 
programs. The system is used to generate pseudorandom binary sequence input signals. perform un-line Fourier transform calculations on the recorded signals, and print out magnitude and phase information at ine conclusiun of each test. Up to eight signals can be processed at a rate of up to three sets of data pei socond. Ait integrating digital voltmeter linits the maximum sampling rate somewhat, but provides excellent noise rejection and small-signal resolution.

The use of minicomputers with data systems has greatly enhanced the quality and quantity of data obtained from experimental desalting plants. Pussible future applications would make use of the computer for direct control of experiments.

1. Reactor Division.

\subsection{NUCLEAR DESALINATION PLANT CONTROL STUDIES}

\section{S. J. Ball N. E. Clapp. Jr. J. G. Delene'}

The dynamic characteristics and controllability of large nuclear desalting piants are being studied io ensure satisfactory operation of the prototype plants now being developed. Previous work included development of digital simulators for multistage flash (MSF) evaporator plant dynamics and dynamics tests on experimental evaporators to obtain data for use $i$. the simulators. Present work includes extending the MSF simulator to insorporate a large power reactor (PWR) and a turbine-generator plant, developing simulators for advanced evaporator designs such as the vertical tube evaporator - MSF hybrid plant, and continuing evaporator expsrimentation.

While previous MSF planit simulations showed that the predicted dynamic stability characteristics are dependent on certain hydraulic design features, recent studies also showied that stability is quite dependent on the means of coupling to the energy source. In fact, the closer the coupling scheme approaches the economically ideal, full dual-purpose plant design (i.e., using back-pressure turbine exhaust steam to drive the evaporators), the greater the tendency for instabilities to occur.

Recent experimental work included application of on-line minicomputers to assist in acquining and analyzing data. Reuse of such a system on a MSF experiment greatly enhanced the quality and quantity of data obtained.

1. Reactor Division.

\subsection{DATA ANALYSIS CRT DISPLAY COMMUNICATIONS}

\section{$\begin{array}{lll}\text { J. W. Reynolds } & \text { N. A. Betz } & \text { R. E. Sellers }\end{array}$}

Operating experience with the CRT display units that support ORELA data analysis on the Immediate Analysis and Coordinating Computer (IACC) indicated a desirability of increasing the operating speed of the data links from 2400 bits/sez to a higher data rate. As a result of a survey of available modulator-demodulators ("modems") with a maximum operating speed of $9600 \mathrm{bits} / \mathrm{sec}$, a General Electric, TDM-330 model was selected to replace existing rented data sets. Before the order for ten units was placed, two were tested on a remote batch terminal connected to an IBM 360/91 via an IBM 270I data adapter.

The faster modems were selected becaus? (1) an increase in transmission speed was desired to reduce the service request response time for ORELA; (2) the cost of a one-year lease for the old modem equaled the purchase cost of the new modern; (3) a unit was desired for the dedicated-line short-term requirements, thereby reducing complexity and cost:(4) factory repair and return maintenance within five working days 
as a backup to local maintenance was available: and (5) the model selected was the lowest cost unit available that met the re puirements.

The units were installed by DEC $^{2}$ in the C15 communication processor of the IACC and the VT 15 CRT display units. and were tested by the Mathematicis Division.

I. Mathematics Livision.

2. Digatal Equipment Corporation.

\title{
6.26 STATUS OF ORELA DATA HANDIJNG SYSTEM
}

\author{
J. W. Reynolds
}

The ORELA data acquisition system' continued to ferform exceedingly well, and usually five or six experimenters obtained data or performed preliminary experiments simultaneously. The maximum obtainable data rate for each computer was increased to $\sim 5000$ events $/ \mathrm{sec}$. New options were added to the display routines. new CRUNCH programs were written, and new routines were prepared to monitor the data collected by each experimerter. Interfaces were built for compurer control of samples and filters during experiments and for muritoring scalers that record neutron intensity, number of accelerator bursts, etc., for each phase of an experiment. To prevent electrical ground loops, electrical isolation was installed on both the multiplexer and the scaler connections between experimenters and the computers.

The immediate analysis computer, a PDP-10 computer, arrived in April 1971. The ORELA has three interactive displays, each containing a PDP-15 computer, and three remote Teletypes with hard-wired computer iinks for program debugging. The extended acceptance tests on all aspects of the system was started in December $1 \rightarrow 71$ and completed on January 19, 1972.

Preliminary prograns for processing ORELA data were prepared, have undergone some testing, and have been used by ORELA physicists. A link was installed and tested between the data acquisition computers and the PDP-10 for rapid transmission of data from the ORELA to the ORNL Computing Center and return of computed results to the line priner ano piotter at ORELA. During 1972, experimenters will be able to do some of the processing and analysis of their data with this system.

i. J. W. Reynolds et al., Instrumentation and Controls Div. Annu. Progr. Rep. Sept. 1, 1971, ORNL-4734, pp. $32-33$.

\subsection{ORELA ISOLATED PULSE GENERATOR}

\section{J. W. Reynolds}

A two-unit-wide NIM module was designed and consuructed to allow exclusive use of twelve program-generated ground-isolated pulses by an experiment ? $\mathrm{r}$ as raquired for experiment control and monitoring. Four of the pulses have a standard use for most experimenters, such as Program Start (PX003), Program Stop (PX004), Program Clear (PX065), and Scaler Reset (PX006). The eight remaining pulses can be used as required by the experimenter. A pulse is generated in the scaler interface by twc nrograms steps: (1) address selection, consisting of a channisl number $X$ and an octal subaddress (0-7), ar. ${ }^{\circ}(2)$ a pulse number $(01-12)$ in any combination. If more than one pulse is selected, they are output in parallel. The device control!' zrs ${ }^{1}$ also use the scaler interfacs: pulse generation feature.

1. R. E. Wintenberg and 3. W. Reyno,ds, Instrumentation and Controls Div. Anmu. Progr. Rep. Sept. 1, !971, ORNL-4734, pp. 26-27, 


\title{
6.28 EIGHT STAGE STACKING BUFFER MEMORY
}

\author{
R. E. Wintenberg J.W. Reynolds
}

A final design of the eight-stage stacking buffer memory was constructed and installed in February 1972. The memory ${ }^{1}$ contains 30 data bits and one control bit per stage. It is a first-in, first-out stcrage module that derandomizes the input events. The 30-bit events are transferred into the buffer memory in 1.4 $\mu \mathrm{sec}$. The average transfer to the SEL $810 \mathrm{~B}$ computer is completed in $20 \mu \mathrm{sec}$.

There have been no known errors with nearly continuous operation at an average rate of $10^{6}$ events/hi (30 events/sec).

I. R. E. Wintenberg. J. W. Reynolds, and A. R. Smith, Instrumentation and Controls Div. Annu. Progr. Rep. Sept. 1, IิY9I. ORNL-4734, p. 34.

\subsection{SPECIFICATIONS FOR ORELA PHASE III ${ }^{1}$}

\section{J. W. Reynolds J. W. Woody, Jr.}

Specification CSP-500-24, dated Nov. 5, 1971, was prepared for purchase of a third data acquisition computer (DAC-3). The compiter consists of a general purpose computer (SEL 810B), a scaler interface for experiment monitoring and control, a four-channel priority multiplexer with a maximum data input of 25.000 events $\sec ^{-1}$ ch:nnel ${ }^{-1}$ (hardware limitation), an on-line CRT display of the collected data, and a fixed-head disk with a storage capacity of $10^{6}$ words. The scaler interface and the multiplexer were specified as electrical and mechanical duplicates of the existing system. The original disk specifications for a semirandom access disk were modified by the addition of an internal adder to allow an increase in the data rate from a maximum of 4900 events/sec into $7.5 \times 10^{5}$ channels to 6000 events $/ \mathrm{sec}$ into $10^{6}$ channels. Installation is scheduled for December 1972.

1. J. W. Reynolds et al., Instrumentation and Controls Div. A nnu. Progr. Rep. Sept. 1, 1967, ORNL-4219, p. 47.

\subsection{ELECTRON SPECTROMETER}

E. Madden

A proposal and estimate for data accumulation and control electronics for a 64-channel, positionsensitive electron spectrometer for the Physics Division was completed. Funds were approved and a specification was prepared and released for bid. Design of the system interface will be started as soon as the hardware is fixed.

\subsection{MODIFICATION OF VARIAN STATOS-III RECORDER}

\author{
E. Madden
}

A Statos-III electrostatic, eight-channel recorder used with the double-arm sweep gage ${ }^{1}$ inspection machine was modified for the Fabrication Systems Development Departinent of Y-12 to furnish more informative strip-chart information and to make operation easier.

The time code generator was modified to print full-scale timing lines across the chart paper at fixed spacings of 1,5 , and 10 lines/in. rather than at fixed time intervals of $0.1,1.0$, and $10 \mathrm{sec} / \mathrm{line}$.

The analog-BCD input control switches were changed to remote computer control. 
The stepping motrit translator was modified to change the chart speed from 1,2 , and 4 to $0.02,0.1$, and $0.5 \mathrm{in}$. $\mathrm{sec}$. Buth switch control and external computer control of all three chart speeds, as well as computer control of a remote asynchronous paper-chart step signal, were provided.

Preamplifiers were designed and fabricated to convert the single-width digital recording channels with 100-incre. nent resolution to double-width channels with 200 -increment full-scale resolution.

1. E. Madden. R. E. Wintenberg. and R. Marcum, Instrumentation and Controls Eir. A nnu Prog. Rep. Sept. 1. 1971. ORNL-4734, p. 32.

\subsection{MODHFICATION OF A BENDIX SWEEP GAGE}

E. Madden

The following devices were íabricated for the Fabrication Systems Development Depattment of Y-12.

A printed circuit board was designed and fabricated to supply two 12-bit digital-to-analog converter channels. This printe $\rfloor$ circuit board was used to obtain increased resolution from two probe-amplifier channels on a Bendix supplied sweep-gage parts inspection machine.

Single-channel-width to double-channel-width preamplifiers were fabricated to replace standard preamplifiers supplied on a Varian Statos-III electrostatic recoriter delivered with a Bendix sweep-gage inspection machine.

\subsection{MODIFIED DEGREE MARKER}
G. W. Allin
E. Madden

A degree-marker design was modified to reduce the fabrication cost of units required for a new diffractometer installation. Each axis drive motor of this computer controlled system has a degree marker that checks the angular position. A light-emitting diode and detector subassembly mounted on a lightweight cantilevered beam, adjusted by controlling the beam deflection, replaces a more complex slide mount arrangement.

\subsection{HB-3 DIFFRACTOMETER CONTROL SYSTEM}

\section{E. Madden}

A long-wavelength diffractometer ${ }^{1}$ for beam hole HB-3 at the ORR was completed, checked, and installed, and is being used in experiments. An additions $4 \mathrm{~K}$ of memory was ordered to increase the memory size of the PDP-8/E to 8K. A second ASR-33 teleprinier and contiol, to be time shared, was ordered for this machine. 31.

1. E. Madden and W. C. Koehler, Instrumentation and Controls Div. Annu. Progr. Rep. Sept. 1, 1971, ORNL-4734, p.

\subsection{NEUTRON DIFFRACTOMETER CONTROL}

F. W. Snodgrass

A diffractometer control interface (Q 5124) for use with a PDP-8/E computer was built and installed to replace a PDP-8/S system.' To avoid the expense of development of new software, this system is program compatible with the PDP-8/S system. The interface provides a 12-bit data scaler, an 8-bit neutron monitor prescaler with switch selectable scaling modulus, a 4bit interrupt register, a 4-bit control register, a 
300-plise/sec clock for motor basic stepping rate, a stepping motor driver, and limit of travel protection circuits. Preamplifiers. amplifiers. discriminates. and high voltage sujplies were also furnished with the system.

1. R. T. Roseberry and A. H. Narten. Instrumentation and Controls Div. Annu. Progr. Rep. Sept. I. 1969, ORNL-4459. p. 41.

\subsection{HB-4 TRIPLE-AXIS NEUTRON SPECTROMETER CONTROL SYSTEM}

\section{E. Madden}

A triple-axis spectrometer,' using a PDP-8/E computer with an 8K memory, was completed, checked, and installed, and is being operated at the HB-4 beam hoie at the high Fiux isotope Reactor (HFIR). A second ASR-33 teleprinter was delivered with the spectrometer to allow time-shared, on-line calculation and program generation for upcoming experiments. 31.

1. E. Madden and H. G. Smith Instrumentation and Contrab's Dis. Anrau. Prog. Rep Sept. 1, 1971. ORNL-4734, p.

\subsection{INCIDENT BEAM MONITOR AND CONTROL FOR A SMALL-ANGLE X-RAY DIFFRACTOMETER}
J. T. De Lorenzo
R. W. Hendricks 1
F. M. Glass
H. N. Wilson
R. E. Zedler

The small angle $x$-ray diffractometer of the Metals and Ceramies Division was modified to incorporate an incident beam monitor and control system.

The monitor consists of a special, low-absorption ionization chamber, ${ }^{2}$ a current integrator (Q-5010), and a timer operated in its external clock mode. The incident beam current is quantized by the integrator and counted to generate a control output signal at some preset count. This additional control function effectively normalizes the data collection to reduce the effect of incident beam instabilities.

1. Metals and Ceramics Division.

2. R. E. Zedler, unpublished work.

\subsection{ELECTRONIC CIRCUIT ANALYSIS PROGRAM (ECAP) WITH PLOTTING ROUTINE AND REVISED PPINTER OUTPUT FORMAT}
J. T. De Lorenzo
C. W. Nestor 1
C. C. Webster ${ }^{1}$

The IBM Electronic Circuit Analysis Program was adapted to the ORNL 360 computer. This program can produce dc, ac, and transient analysis of electrical networks from a description of the network (circuit topology), circuit element values, and circuit excitation.

The transient analysis section of the program was modified to give a plotted ot tput and to revise the format of the printer output. The program was applied successfully to several network problems. The tinree types of analysis were utilized, and the agreement between calculated and measured data was excellent.

1. Mathematics Division.

\subsection{RADIOISOTOPIC SAND TRACER (RIST) STUDY FINAL REPORT}
H. R. Brashear
E. H. Acree'
F. N. Case'

The Radioisotopic Sand Tracer (RIST) study ${ }^{2-3}$ was completed at the close of its sixth year as a cooperative program of the U.S. Atomic Energy Commission, Division of Isotopes Development, and the 
US. Army Corps of Sngineers. The objective was to develop methods and equipment for the study of the movement of littora' sediments along the cost lines of the United States. This objective has been met, and one set of equipment is to be transerred to the Cosstal Engineering Research Center of the US. Army Corps of Engineers to be utilized in on-going programs of constal maintenance.

1. Isotopes Division.

2. H. R. Brashear, E. H. Aure, and F. N. Case, "Scuntilbation Gamma-Ray De:ector for Littorel Transport Studies." Instrumenterion and Controls Dir. Anme Prog. Rep. Sept. 1. 1967. ORNL4219. p. 12.

3. H. R. Brashear, E. H. Auree, and F. N. Case, "Data Colbection System for Littoral Tra usport Studiex" Insmenertation and Controls Div. Anme Prop. Rep. Sept. I. 1968, ORNL 4335. P. 42.

4. H. R. Brestear ex 21. "Computa Fottun of Data from the Mobile Amphibious Detection System Used in Radioactive Isotope Sand Tracer Studies," Ibid. p. 42.

5. H. R. Brashear et al. "Radioisolopic Sand Tracer Study (RIST Status Report for May 1966-Apsid 1968." insenmenterior and Contrats Dir. Annu Prog. Rep. Sepe 1. 1969. ORNL-459, p. 13.

6. H. R. Brasivear. E. H. Acree, and F. N. Case. “Radioisotopic Sand Tracen Study (RIST) Radiation Data Obtained from 198-199 Au Tacine in the October 1968 Fiedd Test at Surf, Zaliformin," Ibid. p. 43.

7. H. R. Brashear et al, "Processins and Azalysis of Radi-isolopic Sand Tracer (RIST) Study Data" Instrumentation and Cononols Dir. Anme Prog. Rep. Sepr. 1. 1970, ORNL-4620, p. 63.

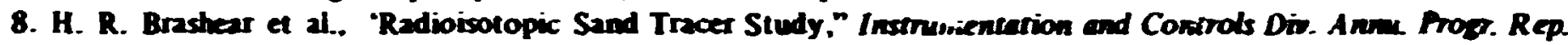
Sept 1. 1971, ORN, 4734, pp. 43-44.

9. R. L. Sirapson and J. M. Jansen. Jr., "Radioisotopic Sand Traces (RIST) Studies Computer System." Ibid. pp. 44-45.

\subsection{COMTUTER SYSTEM FOR THE US. ARMY COASTAL ENGINEERING RESEARCH CENTER}

$$
\text { J.M. Jansen, Jr. R. L. Simpson H. R. Brashear F.W. Snodgrass }
$$

As a resalt of participation of this Division in the Kadioisotopic Sand Tracer Study (RIST), a cooperative program of the AEC and the US. Army Corps of Engineers, development was started on a small computer-based data acquisition system for the Coastal Engineering Research Center (CERC). This system will acquire, analyze, and display graphical data to study the movement of littoral sediments along the coastlines of the I'nited States.

The system, similar to that previously described, ${ }^{1}$ will comprise a PDP-8/E computer with an $8 \mathrm{~K}$ word memory, a storage oscilloscope display, an incremental magietic-tape transport, a keyboard-teleprinter, and an in ierface to a portable radiation detection and data collection system. The computer will be equipped with a cassette tape transport for processing data stored on cassette when disconnected from the computer system.

Programs developed for the RIST study will be used for operation of the data system. Several modirications will be implemented to rapidly store and retrieve programs for analysis from the mapnetic tapr aransport.

1. H. R. Brashear et al., Instrumentation and Controls Div. Annu. Progr. Rep. Sept. 1, 1971, ORNL-4734, pp. 43-44.

\subsection{CONTROL UNIT FOR A PORTABLE GAMMA SPECTROMETER}

\section{F. W. Snodgrass}

A control unit was built to serve as an integral part of a gamma spectrometer for acquiring and recording data in radioisotopic sand tracer ${ }^{1}$ tests by the Coastal Engineering Research Center, U.S. Corps of Engineers, for study of the movement of sand and silt in harbor and coastal waters. Some of the design objectives were: portability, low power consumpiion, power from ordinary storage bafteries, reliability in severe environments, ininimum interequipment cabling, and simplicity of operation by nontechnical personnel. 
Low-power TTL integrated circuits were used extensively throughosit the instrument. A solid-state readuut assembly displays the clock time. The instrument has a self-contained cigital magnetic-tape cassette recorder for data storage. Data can also be recurded on paper tape or transferred directly 10 an wibuard computer. Data consists of time. two chanrels of gamma counts. two range (position) parañeters. and water depth. The instrument cabinet accommodates a plug-in Technical Service Unit (Sec:- 1.11) which contains the detector amplifiers. discriminators, and high voltage supplies.

I. H. R. Brashear et al. Irstrumientation and Controb Dir. Anmu. Progr. Rep. Sept. 1. 1971. ORNL-4734. Pp. 43-44.

\subsection{CASSETTE CONTROLLER}

\section{F. W. Snodgrass}

A controller to enable computer control of a digital, magnetic-tape cassette transport was designed. Data will be rerorded and played back in a bit-sarial mode and transferred to and from the computer a parallel 8-bit characters. The recording technique used is phase encoding with a packing density of 800 bits/in. ( 1600 flux transitions per inch) arid tape speed of 6 in/sec. A dual-gaf head permits error checking at the time of reco-ding Construction of the controller for use with a PDP-8/E computer is near completion. This system will be used for :eading spes iecorded or. a portable gamma spectrometer and for general purpose programming and data storage.

\subsection{MOBALE FUEL-ASSAY VAN}

\section{E. McDaniel V.A. McKay $\quad$ R.T. Roseberry}

Activity was started to assist in equipping a mobile fuel-assay van for the US. Atomic Energy Commission. The purpose of this mobile unit is to inventory ${ }^{235} \mathrm{U}$ content of fuel at fabrication sites. The van is equipped with a sodium iodide spectrometer detector connected to a computer-based multichannel analyzer. The equipment is mounted in a shock-mounted frame and is cooled by air ducted from an overhead air conditioner mounted on the cab of the specially prepared $3 / 4$ ton van.

This Division started preparation of instructions for the measurement techniques, including data acquisition, calibration, and analysis. Also, modification of equipment and preparation of a specialized computer program were started.

A new 3- by 3 -in. sodium iodide detector and shield are being installed, calibration sources are heing prepared, and ${ }^{235} \mathrm{U},{ }^{238} \mathrm{U}$, and ${ }^{235} \mathrm{U}^{238} \mathrm{U}$ response functions are being determined, as well as appropriate geometries for the variety of samples to be measured - powder, pellets, and microspheres.

\subsection{COMPUTER-BASED MULTICHANNEL PULSE-HEIGHT ANALYZER AND SAMPLE CHANGER FOR ECOLOGICAL STUDIES}
E. McDaniel
L. R. Gitgood
R. T. Roseberry

A gamma counting facility for ecological studies was designed and constructed for use in the Aquatic, Terrestrial, and Heavy Metal Tracer Program by the Environmental Sciences Division. A computer-based pulse-height analyzer was interfaced to an existing auto-gamma sample changer and a mantally loaded liquid scintillation counter. A custom programming system was prepared to enable a system capability of automatic quantitative measurements of one or two isotopes in up to 43 samples. 
The program interaits through a telefrinter in a conversational mode with the uperator during setup of an experiment. Once calibrated, the system will operate unattended urtil the presiribed number of samples has been ana'yzed. Since the program requires mi *..al training of the cperator, the system is an ideal research tool ror summer participants.

Through its interface. this computer controls all functions of the 50-sample carrousel during in: experiment. A complete set of manual controls is available, however. tinat can be used at any time to loed or unload a sample, move to a new sample position, or find the reference position. A switch allows the operator to disable the compiter control of the sample changer and enable the logic circuits on the manually loaded counter. Other switches on the counter simulate the action of the switches in the sample changer so that loading and unloading samples manually appears to the computer to be the same as the automatic operation. The single programming system works equally well with either counting system.

\subsection{AUTOMA TC SAMTE CHANGER}

\section{G. W. Allin R. T. Roseberry}

Fabrication of an automatic sample changer was started. This unit will handle samples in a radiation counting facility. The samples, maximum of 20 , will be placed in $8-02$ polypropylene jars before being loaded into the changer. The changer will automatically position the samples in one of four counting positions according to the intensity of the sample activity. The changer will be controlled by a computer; the main function of the computer will be data acquisition.

\subsection{MASTER CLOCK-COMAUTER MARKER GEMERATOR FOR ORMAK}

\section{D. Bates}

A master ciack to provide precise timing pulses for the ORMAK machine of the Thermonuclear Division was designed and fabricated. The clock, designed in a single-width NIM module utilizing TTL logic,

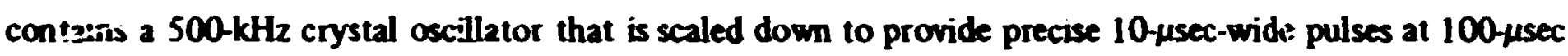
intervals. The module has two outputs: a local to drive the waveform synthesizer inside the control room, and a remote to supply timing pulses external to the control room.

The clock is further scaled to provide timing markers to the LNC-8 computer. The output from this section is switch selectable to obtain either $1-, 10$, or $100-\mathrm{msec}$ square-wave timing pulses. A control decade scaler inhibits the ma:ker timing pulses to the computer except the 100 -msec experimert run time. 


\title{
7. Process Instrumentation and Control SYSTEMS ENGINEERING
}

\subsection{UTGRDING OF STEAM FLOMMETERS}

\author{
R. F. Hyiand
}

Upgrading of the steam orifice meter installations on the main 50-psig headers in the Central Research and Administration Building 4500N and 45005 and the Metals and Ceramics Laboratory Building 4508 and on the 225-psi header in the High-Voltage Accelerator Laboratory Building 5500 was compteted. The instrumentation associated with these steam systems had not been calibrated since the building becamse operational. and this work consisted of recalculation of all nows. replacing orifice plates where necessary, and cleaning and recalibration of the remainder of the instruments. The objective of the work was to ensure accurate flow data for utility billing purposes.

Computer programs in the BASIC language for calculating steam. vapor, and liquid flows were improved and rewritten in ADVANCED BASIC: the latter p:ograms were then used for the precise calculation of flow vs instrument readings for all of the flowmeters.

\subsection{ELK RIVER DISMANTLNG PROJECT}

\section{W. R. Miller B. Lieberman}

Contractual commitments of the AEC require that the power reactor a: Elk River. Minnesota, be dismantled and disposed of at the end of its useful life. Design and constructicn of a control system package to remotely position and control a plasma-arc cutting torch fer this purpose were assigned to this Division.

A thermal liner, 81 in. in diameter, $18 \mathrm{ft}$ long, and constructed of 1 -in.thick stairless steel. must be cut under water because of the high level of radioactivity. The reactor vessel of 3-in.thick carbon steel will be cut in air.

The torch current will be $1000 \mathrm{~A}$ at $180 \mathrm{~V}$ dc. The gas flow will be 500 scfh to achieve cutting speeds of $50 \mathrm{in} . / \mathrm{min}$.

The control system will enable automatic sequencing, gas flow and pressure interlocking, current-source and arc-starting equipment control, as we!l as sensing and indication of all parameters.

A remote positioning and indicating system for the torch will be an integral part of the package. The position accuracies will be $0.1 \mathrm{in}$. in $20 \mathrm{ft}$ in the vertical plane and $0.1^{\circ}$ in $395^{\circ}$ of rotation in the horizontal plane. The system will be equipped for making settings at reference locations so that the speed of torch travel will automatically increase and decrease as cuts are begun and ended. SCR motor drives under control of the positioning system will maintain speed control within $0.1 \%$.

There will be five modes of starting to cope with conöitions that will prevail as dismantling progresses. Each function can be pretested prior to running an automatic cycle.

Figure 7.2.1 shows the control panel which houses most of the auxiliary control equipment, thereby making a complete package that will be shipped and set up in a minimum of time at the reactor site after 

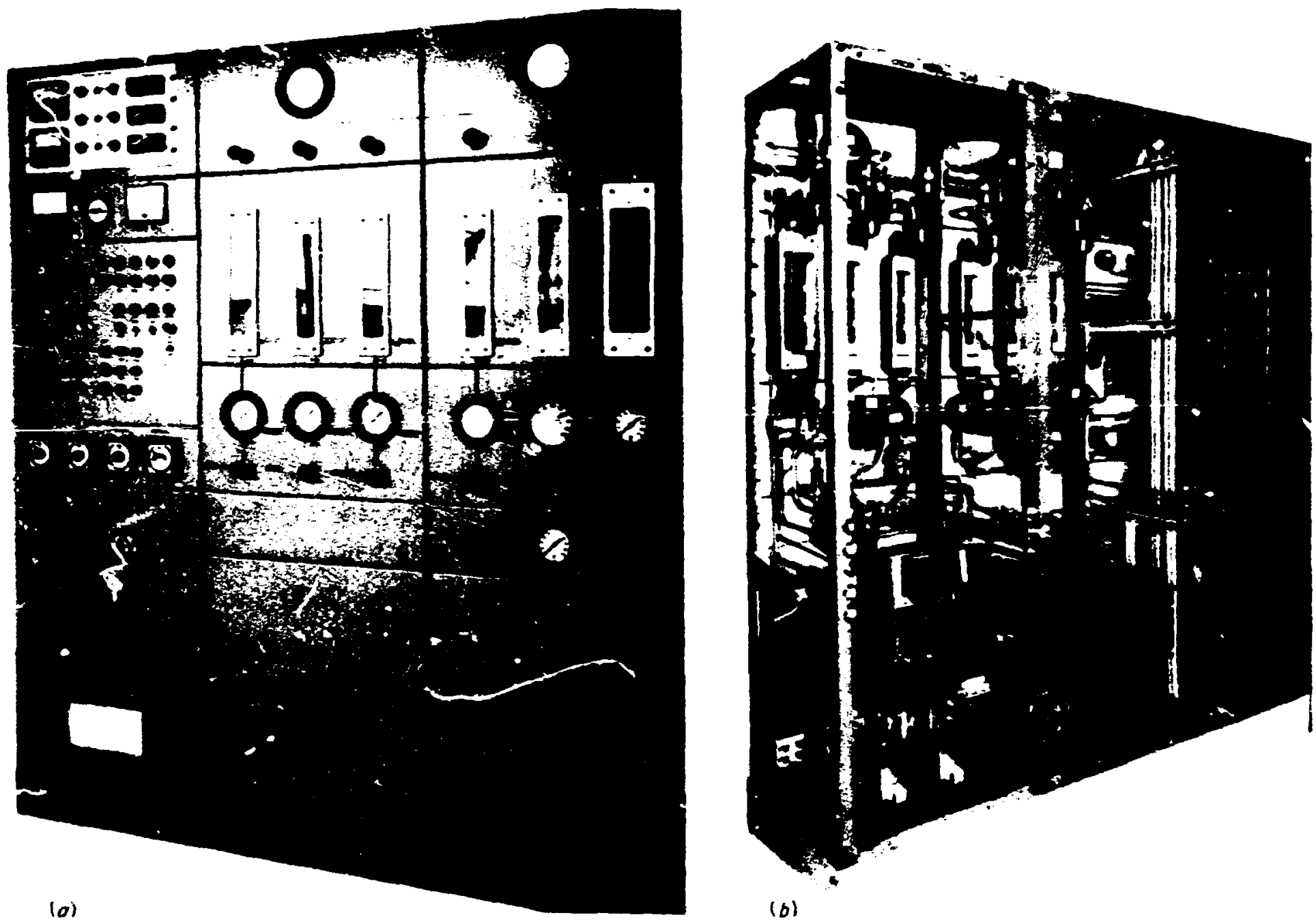

(b)

Fig. 7.2.1. Control system for plasma-arc cutting torch. (a) Front panel and (b) rear panel.

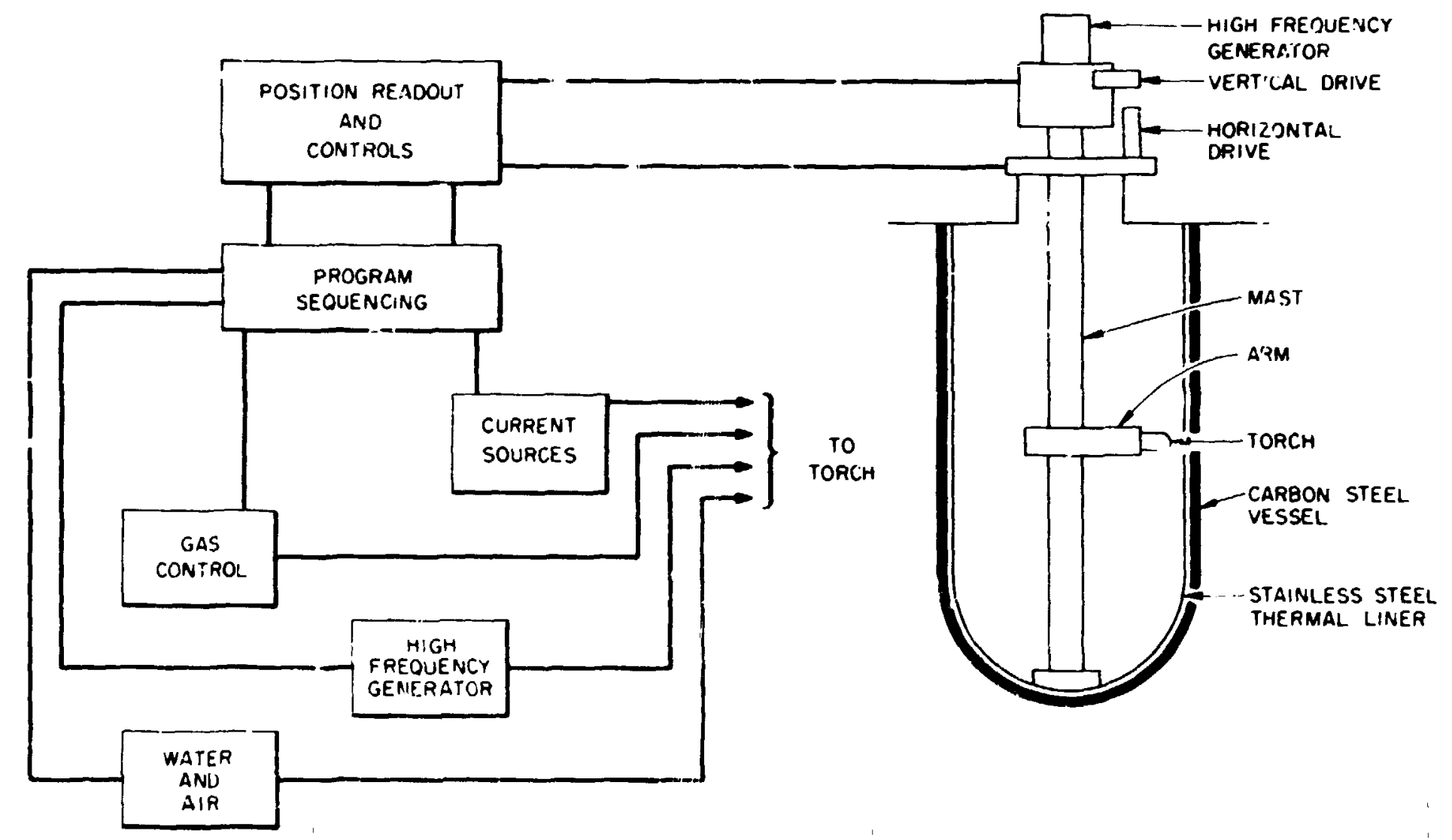

Fig. 7.2.2. Diagram of control system for plasma-arc cutting torch. 
mock-up tests at ORNL are completed. Figure 7.2.2 shows the generai layout of the hardware and a block diagram of the system.

\title{
7.3 THERMAL TESTS ON A FOAMGLAS SHIPPING CONTAINER
}

\author{
H. E. Cochran $\quad$ C. A. Mossman
}

The thermal test made on a Foamglas shipping container ${ }^{1}$ ( 23 in. OD, 35 in. long) verified that it would meet the thermal requirements set fourth in the U.S. AEC marual, ${ }^{2}$ i.e., there was no damage to the inner container that would result in loss of radioactivity.

The container was exposed to a temperature environment of $1475^{\circ} \mathrm{F}$ for $30 \mathrm{~min}$. Eight ChromelAlumel, shielded, insulated-junction thermocouples were connected to a multipoint null-balance chart recorder to indicate and record the temperature during the test.

In a previous thermal test, flammable gases were evolved, causing erratic behavior of the furnace controls, and large electrical-field fluctuations occurred as the power was switched on and off. Consequently, the temperatures obtained were unreliable. For a successful test, the materials used in the contziner were modified to minimize gas evolution. The effects of stray electrical currents induced by the pulsed-furnace heater power were eliminated and good data were obtained by using thermocouples with insulated junctions and by installing intact thermocouple assemblies of thermocouple wires, insulation, and sheath from the point of measurement in the furnace to a disconnect box outside the furnace. The thermocouple lead wires from the junction box to a null-balance chart recorder were enclosed in conduit.

1. B. B. Klima et al., Drop, Puncture, and Thermal Tests Performed on the Foamglas Shippin: Container, Dot Special Permit No. 5795, ORNL-TM-3713 (April 1972).

2. Ibid.

\subsection{ANALYSIS OF ERRORS IN LINEAR VARIABLE REIUCTANCE TRANSDUCER}

\section{J. M. Googe'}

Commercial linear variable reluctance transducers (LVRT) are used with linear voltage differential transducer (LVDT) data modules made by another manutacturer to measure linear motion in the Mint 1 experiment at the Oak Ridge Research Reactor (ORR). The use of these transducers to measure fuel-cladding mechanical interactions was hampered by a series of instrumentation malfunctions, 2nd, on occasions when no obvious malfunctions were detected, the data produced by the transducer system were unrealistic.

This investigation revealed thermal effects to be a major source of both calibration changes and device damage. The specified LVRT had a certified linearity of better than $1 / 2 \%$ of output over a displacement range of $\pm 0.250 \mathrm{in}$. As received, it was calibrated for temperatures from 50 to $450^{\circ} \mathrm{F}$, but the calibration certificate showed the gain, or sensitivity, to change about $2.4 \%$ over this temperature range under laboratory conditions. Since the temperature environment for the LVRT at the reactor was at lei:t this severe and the required displacement resolution was about $1 \%$, the displacement data were seriously degraded by temperature effects.

Analy tical models were used to demonstrate a principal source of the temperature error and to suggest corrections for improving the quality of the data obtained.

Figure 7.4.1 shows the inajor components of the displacement instrumentation and is useful in discussing the errors in the system. The basic seising is performed by an impedance bridge composed of $R_{1}$, $R 2$, and the two coils in the LVRT, $\mathrm{X} 1$ and $\mathrm{X} 2$. The bridge power is supplied by a 3-kHz constant-voltage 


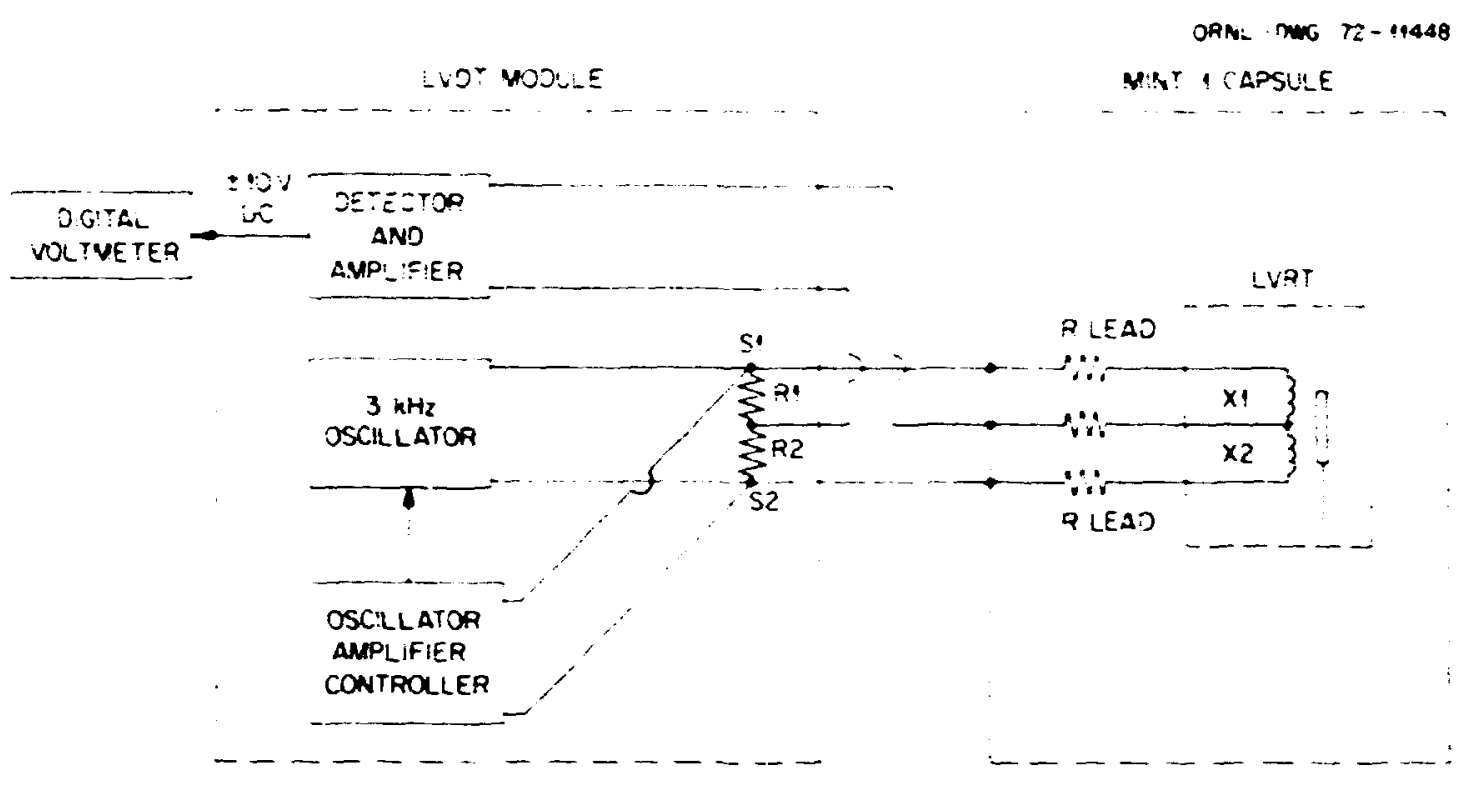

Fig. 7.4.1. Diagram of LVRT system.

source that has an automatic voltage-control loop to keep the voltage across points $S 1$ and $S 2$ constant at about $3 \mathrm{~V}$ rms.

The LVRT sperifi:d by the manufacturer in his test report (or calibration certificate) was operated at 5 $\mathrm{kHz}$ wit' $10 \mathrm{~V}$ ms. This higher frequency, compare - with the $3 \mathrm{kHz}$, caused the transducer coil reactance to be proportionally higher and made the temperature effects less important. The null voltage also improved when the transducer was operated at design frequency.

Figure 7.4.2 is an approximate equivalent circuit of the LVRT and bridge as used in the Mint 1 experiment. We assume that $X_{T}=X_{B}$ when the core of the LVRT is centered $(x=0)$ and that the change in reactance of the upper and lower coils is linear with core position, $X$.

Then using voltage division, we write

$$
\frac{E_{\text {out }}}{E_{\text {in }}}=\underbrace{\frac{R 2}{R 2+R 1}-\frac{R L 3+r_{B}+j X_{B}}{R L 1+K L 3+r_{T}+I_{B}+j\left(X_{B}+X_{T}\right)}}_{\text {set to zero by zero adjustment in the LVDT }}
$$

$$
+\frac{j \Delta X}{R L 1+\underbrace{R L 3+r_{B}+r_{T}+j}_{\text {useful output }}\left(X_{B}+X_{T}\right)} .
$$

This equation was used to calculate a decrease in gain caused by the added line resistance of about $5 \%$. The calibration factor obtained from bench calibration without the 6.3- $\Omega$ line resistance must be multiplied by 1.05 . The equation also reveals several other important features of the LVRT:

1. The gain or calibration constant is a nonlinear function of the lead and cooil resistance.

2. The effect of coil and lead resistance is reduced as the coil reactance is increased. For this reason, one component of the temperature dependence is reduced when the bricge supply frequency is increased.

3. An unbalanced change in lead or coil resistance will produce a zero shift and a gain change in the instrument channel. Thus, thermal gradients cause zero shift and gain changes. 


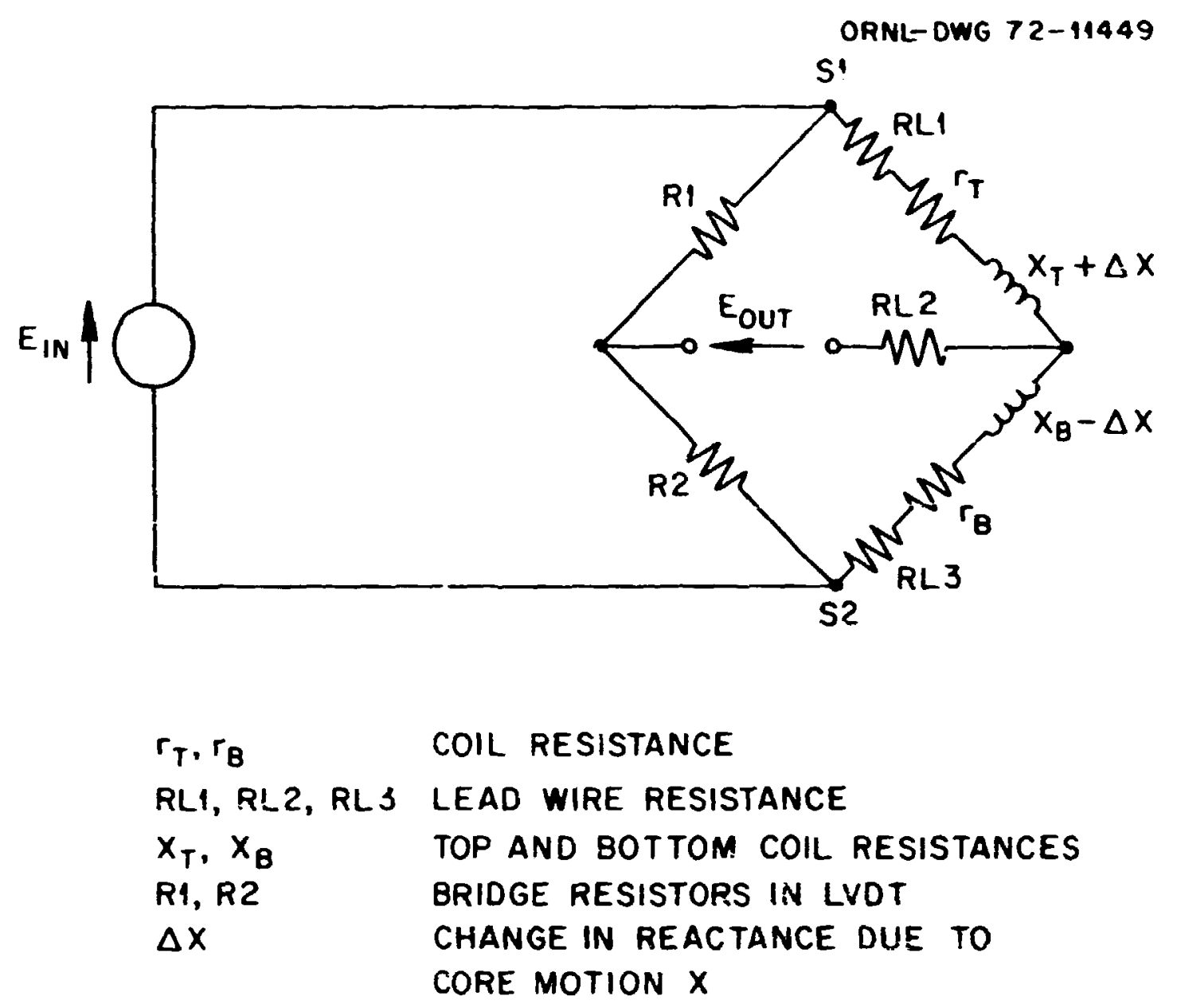

Fig. 7.4.2. Approximate equivalent circuit of LVRT and bridge in MINT $i$ experiment.

In summary, the effects of elevated and nonuniform temperatures on the zero and span of an LVRT can be predicted using an equivalent circuit nodei of the device. These predictions reduced the error from uncorrected data to about one-half in a bench calibration with controlled temperature conditions.

The results of this work are valuable both for reducing the error in the data from the Mint 1 experiment and for establishing bounds on temperature errors in this class of transducer to be used for guidance in future systems.

1. Consultant from the Electrical Engineering Department. the University of Tennessee, Knoxville.

\subsection{TRAPSURANIUM PROCESSING PLANT}

\section{H. E. Cochran}

\section{M. Chiles \\ P. W. Hill \\ B. C. Thiompson \\ J. T. De Lorenzo \\ R. E. Zedler}

Successful operation of the Transuranium Processing Plant (TRU) was continued, recovering $300 \mathrm{mg}$ of ${ }^{252} \mathrm{Cf}$ from the SRP reactor tubes for the Division of Production program As by-products, ${ }^{249} \mathrm{Bk}$ and ${ }^{254} \mathrm{Es}$ were made available for $\mathrm{rcsearch}$ use. From nine HFIR targets $170 \mathrm{mg}$ of ${ }^{252} \mathrm{Cf}$ and other isotopes were recovered. Much of the material was incorporated in neutron sources and shipped to researchers throughout the countrv.

Instrumentation previously installed in the source and target decontamination facility for issaying californium sources and shipping packages by means of fast-neutron counting proved most worthwhile. Reproducibility of assay values was within $1 \%$ and usually within $0.5 \%$ A similar system was installed in the Thorium-Uranium Recycle Facility (TURF) where the isotopes are encapsulated prior to transfer to TRI by a pneumatic tube for decontamination. 
Two technicians, a foreman, and an engineer were available for i.strumentation support during the past year. The reliability of the instrumentation and the minimal process changes planned will enable a reduction of manpower fer instrumentation services by $\sim 1 / 2$ in the coming year.

1. H. E. Cochran et al., Instrumentation and Controls Div. Arnu. Progr. Rep. Se?t. 1, 1971, ORNL-4734, pp. 46-47.

\subsection{IMPROVED LIQUID-WASTE TREATMENT AND STORAGE FACILIT:ES}

\section{R. L. Toucey}

The General Engineering Division was assisted in preparing conceptual-design docurrents, drawings, and cost estimates for the improvement of the Liquid-Waste Treatment and Siorage Facilities at the Laboratory. This information will become part of a proposal to the Atomic Energy Commission. The following facilities are being planned:

1. A new evaporator facility to match the capacity of the radioactive-liquid-waste evapurator in Building 2531. The new evaporator could be operated for additional capacity or as a standby unit when the older evaporator is shut down for repair.

2. A new waste treatment plant to filter the radioactive process liquid waste. The new plant, with a 200-gpn capacity, will replace the existing facility in the Process Waste SYater Treatment Plant (Building $3518)$.

3. A new radioactive-liquid-waste handling and interim tank storage system. The new system will have five new tanks with a total storage capacity of $660,000 \mathrm{gal}$.

\subsection{HTGR FUEL REFABRICATION DEVELOPIAENT PROGRAM}

\section{H. E. Cock.an B. Lieberman}

The objective of the HTGR fuel refabrication development program is to develop the technology necessary for the design and operation of ? pilot-scale, remote-fueled graphite line in the Thorium-Uranium Recycie Facility (TURF). An engineer was assigned half time for instrument assistance by keeping abreast with the program and directing instrument problems to engincering specialists of this Division.

The small PDP-8/E digital computer ${ }^{1}$ was instalied and successfully operated. The digitized output from a split-image eyepiece furnished measurement data to calculate particle diameters and coating thickness of fuel microspheres. Plans were made and work was started to expand the use of the computer (Fig. 7.7.1).

Based on experimental data and calculations obtained from studies of coated particles processed in the fluidized-bed coating furnace, the hydrocarbon and helium flow rates were revised. The process instrumentation (12 lin $\mathrm{ft}$ of control board instrumentation as well as fielu-inounted units) is now being resized, calibrated, and updated to meet these new requirements.

Fabrication of fuel sticks requires development of instrumentation to characterize the nominal $1 / 2$-in.-diam, 2-in.-long sticks. The pilot plant fabrication rate will be $\sim 9000$ sticks per day. Temperature controls and interlocks were developed and tested for a prototypic fuel stick machine recently placed in operation. Automatı: dimensional measurement of the sticks is planned. To determine the aricunt of fissionable material in each stick, a multispectra reutron irradiation technique is being inves'igated. The protorype control was designed and is being evaluated.

1. H. E. Cochran and C. D. Martin, Jr., Instrumentation and Controls Div. Annu. Progr. Rep. Sept. 1, 1971, ORNL-4734, pp. $47-48$. 


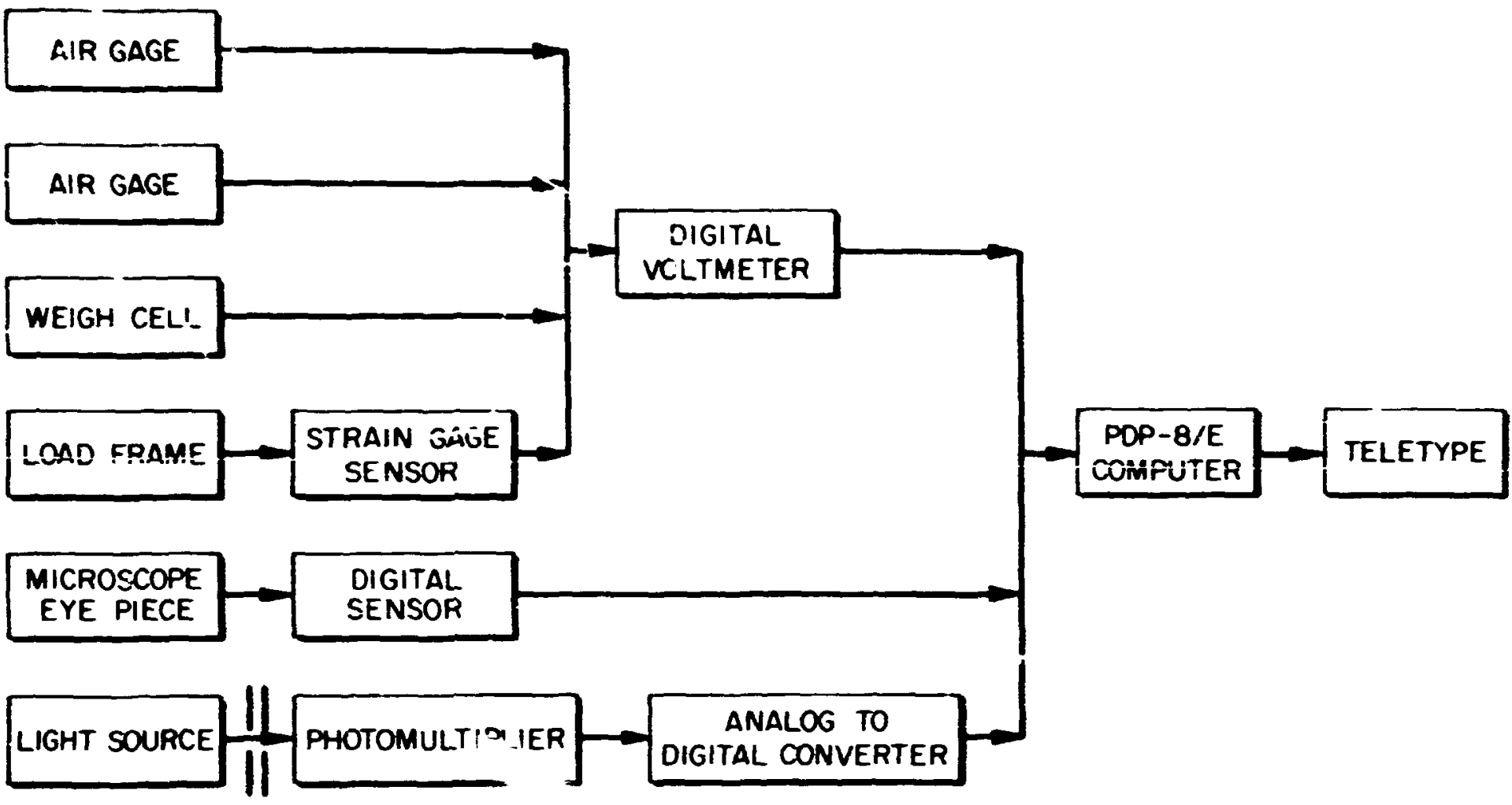

Fig. 7.7.1. HTGR fuel characterization data system.

\title{
7.8 AQUATIC LABOR ^TORY DESIGN STATUS
}

\author{
B. C. Duggins \\ J. T. Hutton J. M. Jansen, Jr. B. Lieberman
}

The preliminary development and design of instruments for the aquatic laboraiory were reported. ${ }^{1}$ The facility was constructed and will be available for ORNL use in the fall of 1972. Since the computer system is not funded as a part of the facility, the initial operation will be with manual control of the three-way blending valves for tank temperature control. Since the hot- and cold-water heaiers are controlled with analog controllers, there should be a fixed relationship between the blending valve position and delivered water temperature. We expect the computer system to be funded during FY 1973.

One important change in the design of the computer, temperature-control system was made when low-cost (<\$50), 10-bit, digital-to-analog converters (DAC) became available. As reported last year, stepping motor drives 'were planned for the blending valves, but control of these motors would be expensive and cumbersome and would have required extensive wiring to be located in the damp atmosphere of the tank room. The new system will have a conventional pneumatic blending valve with an individual DAC and an electric-to-pneumatic converter for each loop. The PDP-8/E computer will load desired valve position information into registers for each of the DAC circuits. Prototypes of the circuit cards were fabricated to fit and be an integral part of the computer panel. The electric-to-pneumatic converters will be installed behind the panel, and the pneumatic signal tube will be run from the computer room to the tanks. Tests of the prototype circuits, using a PDP-8/1 system, gave satisfactory results.

1. B. C. Duggins and J. M. Jansen, Jr., Instrumentation and Controls Div. Anmu. Progr. Rep. Sept. 1, 1972. ORNL-473t, pp. $124-2 j$. 


\title{
7.9 UPDATED INSTRUMENT ENGINEERING DRAWINGS AND DOCUMENTS
}

\author{
R. E. Toucey
}

Drawings and documents from existing Laboratory acilities were reviewed and updated so that the installed instrume:ts and control systems would be described accurately. To dite, drawings for the Radiochemical Processing Pilot Plant (Puilding 3019) were checked and revised to conform to the existing emergency control system and to include rivisions to the system requested by the U.S. Atomic Energy Commission Safety Review Committee. The Tower Shielding Facility drawings of the process control instrumentation are being checked and revised to show "as-built" installation. A new engineering flowsheet to describe the instrument air system for the Tower Shielding Facility was prepared to augment the documentation of the existing facility.

\subsection{WATER QUALTYY MONITORING}

\section{B. C. Duggins \\ G. W. Allin T. F. Sliski W. R. Miller H. J. Stripling, Jr.}

To assure that ORNL complies with all environmental regulations concerning liquid effluents, water quality monitoring stations were installed at three sites along the streams into which plant waste-water flows. The variables monitored are water $\mathrm{pH}$, dissolved oxygen, teraperature, and flow rate. This new monitcring system was added to the existing radiation monitoring system. The information is telemetered (using commercial telephone lines) from the $f-1 ;$ sites to reccrders at two locations in the main "avoratory area. The water quality monitoring system is operational, and its performance is satisfactory.

Consultation with several authorities, including the Environmentai frotection Agency, concerning the best way to make these measurements led to an ibiporiant conciusion that it is not good practice to pump a sample from the stizam because the dissolved oxygen concentration in the sample is affected by pumping. Also, it is essential to measure these variables at the area of greatest flow in the siream cross section, which is in the center of the stream and near the surface. For these reasons, the sensors were installed on a float assembly consisting of pontoons, made from aluminum and stainiess steel, with the flotation chambers filled with low-density polyurethane foam. The sensors were mounted on the float so that they can be adjusted individually for depth in the water or serviced. Cables from the bank to the float are supported from a boom that can be rotated to bring the float to the bark for maintenance.

Since commercially available instruments were used for the measurements, the output signals from instruments had to be converted to a 0 to $4-\mathrm{mAdc}$ range for telemetering The converters were designed and fabricated by this Division with integrated circuit components, printed circuit boards, and NIM bin hardware. Three different converter types were required. A voltage-to-current converte: was required for $\mathrm{pH}$ and oxygen. For flow, a pulse duration-to-curient converter was required. This flow converter closes contacts for 3 to $12 \mathrm{sec}$, which is linear with the percentage flow rate, and digital and analog techniques convert this signal to a 0 - to $4-\mathrm{mA}$ dc signal which is updated every $15 \mathrm{sec}$. For temperature measurements, the converter type is resistance-to-current, with sufficient sensitivity for a range from 5 to $30^{\circ} \mathrm{C}$. The probe contains two thermistors of different characteristics which are used with a linearizing circuit to yield a current output linear with temperature.

The most difficuli development problem encountered was to adequately protect the integrated circuits from lightning. Although all circuits were initially equipped with high-frequency chokes and spark-gaps, induced transients of intolerable voltage levels were observed. This problem was iesolved by the addition of Zener diodes to the protection circuits. 


\title{
7.11 MODIFIED HELIUM LEAK DETECTOR FOR FLOW MEASUREMENT
}

\author{
$\begin{array}{lll}\text { H. E. Cochran } & \text { B. Lieberman } & \text { C. B. Williams }\end{array}$
}

Control rod iffe for the Fast Test Reactor is iimited due to helium generated from ${ }^{10} \mathrm{~B}(\mathrm{n}, \alpha)^{7} \mathrm{Li}$ reaction. Tr, develop and test control rod vents, an instrument was required to measure leak rates of $10^{-4}$ to $10^{-3} \mathrm{std} \mathrm{cm}^{3} \mathrm{sec}^{-1}$. Since a commercial instrument was not available for this purpose, a commercial helium leak detector was modified to measure helium flows in the range desired. The biasing resistor was changed to prevent saturation of the electrometer tube due to the greater flow of helium ions.

A control switch, reed relay, and power supply were added to allow selection of either standard operation of the leak detector with either iow helium flow or high helium flow. A commercial helium leak of relatively high flow $\left(1.78 \times 10^{-4} \mathrm{std} \mathrm{cm}^{3} \mathrm{sec}^{-1}\right)$ was purchased for calibrating the instrument at the higher helium flow rate.

\subsection{PRESSURE SAFETY OF GLOVE BOXES}

\section{B. C. Duggins B. Lieberman}

Design studies of pressure control and safe.y systems for glove boxes ${ }^{1}$ were continued. Interest quicikened recently when pressure excursions were experienced with sume recirculating inert-atmosphere glove boxes. This type of glove box is usually purchased with pressure controls sutplied as part of the gas purification syster. The safety of the inert-atmosphere boxes was assessed, and they were modified as necessary. The practice was to make the safety of the boxes independent of the supplied controis; the maximum pressures of the gas and vacuum sources were set and relief devices were installed to adequately handle th.ese positive and negative pressures. Operation of these safety devices was proved after thei: installation by simulating failure of the pressure control system.

1. B. Litberman and A. H. Malone, Instrumentation and Controls Div. Anmi. Progr. Rep. Sept. 1, 1970, ORNL-4620, pp. 66-67.

\subsection{ROUX-TYPE DROP CALORIMETER}

\section{J. M. Googe B. G. Eads W. W. Johnston, Jr.}

Research for the Radioactive Waste Repository Project require measurement of the stored energy of irradiated salts. The experimental apparatus, suggested by the work of Roux, ${ }^{1}$ consists of a drop-type calorimeter and temperature instrumentation. The experiments called for high resolution of temperature and high stability with the apparatus operating at relatively high nominal temperature $\left(1000^{\circ} \mathrm{C}\right)$ and for measurement of a very small temperature difference.

The calorimeter, special temperature instrumentation, and a stable furnace power supply were supplied. The calorimeter was fabricated from commercially available high-purity alusina. High resolution was obtained by use of a Pt vs Pt-Rh differential thermopile followed by an ainalog function generator and a high-gain amplifier.

The function generator produces a voltage transient that is analogous to the temperature transient which uffects the thermopile when an unirradiated salt sample is dropped into the calorimeter. This signal is generated in synchronism with and sibtracted from the thermopile signal produced when irradiated salt samples are dropped into the calorimeter. The small difference between the function generator and thermopile signals is amplified by the high gain amplifier and recorded for analysis. The area under the transient differential signal for an unirradiated sample is compared with that for an irradiated sample to 
obtain a measure of the stured energy due to irradiacion. This differential technique places very severe stability requirements on the instrumentation.

Roux reported good results using a lumped version of an RC transmission line to simulate the thermal transient. This device is a logical choice since transients on an RC line and certain one-dimensional heat transfer problems obey the same equilibrium equation

$$
\frac{\partial^{2} v(x, t)}{\partial x^{2}}=\frac{1}{a} \frac{\partial v(t, x)}{\partial t}
$$

where $\alpha$ is the diffusivity in a thermal case or the time constant in an electrical case, and $v(x, t)$ is the voltage or temperature, as the case mas be.

The function generaior was buiit and is in service. It is reported to meet the project requirements as to wave shape and stability.

1. Andre Roux, Energie Emmagusinee dans les $\mathrm{Oxydes} \mathrm{BeO}, \mathrm{MgO}_{8} \mathrm{Al}_{2} \mathrm{O}$ et $\mathrm{SiO}_{2}$ irredees $\mathrm{Aux} \mathrm{Neuth}$ ons, Sc.D. These A La Faculte des Sciences, Del'U. of Lyon (Dec. 1969).

\subsection{ENGINEERING SUPPORT FOR THE METALS AND CERAMICS DIVISION}

\section{B. G. Eads J.T. Huitton}

histrument engineering support to the Metals and Ceramics Division was continued.' The tasks completed were as follows:

1. Prepared a cost tstimate for precurement and installation of a new hydrogen-leak detection system and prepared the specification for purchase of this system.

2. Assisted in the preparation of a specification for a high-pressure-gas bonding system.

3. Designed a programmed high-temperature furnace control system.

4. Supplied miscellaneous high-temperature sensors.

5. Designed and fabricated a dual-channel recorder driver for display of the voltage and current outputs of a heliarc welder.

6. Fabricated a cyclic controlled-strain analog computer for use in fatigue testing of metallurgical samples (this was an adaptation of a General Electric design).

1. B. G. Eads, Instrumentation and Controls Div. A nnu. Progs. Rep. Sept. 1, 1971, ORNL4734, p. 50.

\subsection{SPECIFICATIONS FOR ANNUNCIATORS AND FOR TEMPERATURE SHUTDOWN DEVICES}

\section{H. J. Metz}

A survey was made to learn the experience with annunciators and temperature shutdown devices in the three plants operated by the Union Carbide Corp. in Oak Ridge. This : done because there is a need for ip-to-date specifications for equipment that uses solid-state components and would requir' less frequent and more economical maintenance. Commercially available equipment is being evaluated, and annunciators and temperature shut town devices judged to be best are being purchased and tested. Specifications will be written for procureri: snt of solid-state annunciators and temperature limit switches. 


\title{
7.16 GAS CYLINDER STATION
}

\section{H. J. Metz}

A gas cylinder station was designed and installed on the soutl: side of the Instrument Laboratory (Building 3500). Twenty-five cylinders can be stored or used at this station, with room to increase the cylinder storage threefold. The cylinders and equipment in use are protected by a 4 by $32-\mathrm{ft}$ aluminum canopy. The gases will flow through tubes to the places of use in the building, eliminating the practice of temporary benchside mounting of the heavy, high-pressure cylinders with their attendant safety problems.

\subsection{IMPROVED WIND TUNNEL}

\section{H. J. Metz}

The wind tunnel in the basement of the Instrument Laboratory (Building 3500) was inadequate for calibrating gas-velocity measuring instruments for the Central Radioactive Gas Disposal Facilities (Building 3039). At low flow rates, the accuracy of the measuring elements was insufficient; and at high flow rates, the air supply was insufficient. A new air supply was installed and the wind tunnel will be modified to enable tests and calibration of air velocity devices in a gas velocity range from 20 to $800 \mathrm{ft} / \mathrm{sec}$.

\section{DE:'ELOPMENT INCLUDING BIOMEDICAL INSTRL'MENTS}

\subsection{A MULTICUVET FAST FLUOROMETRIC ANALYZER BASED ON THE GEMSAEC PRINCIPLE ${ }^{1}$}

\author{
T. O. Tiffany ${ }^{2}$ \\ $\begin{array}{lll}\text { L. H. Thacker } & \text { C. A. Burtis } & \text { C. D. Scott } \\ & \end{array}$
}

A prototype 15-cuvet fluorometric analyzer based on the GeMSAEC principle has been develuped to demonstrate the feasibility of automated fluorescence analysis on the Fast Analyzer. An existing 15 place analyzer was slightly modified for angled excitation using a simple fiber optics system. In this manner either system retains the unique parallel analysis capabilities of a Fast Analyzer. Initial develop..ent has centered on the use of 470-nm excitation and 530-nm emission detection. A semimicro cortisol analysis has been adapted using procedures similar to those of Silber (Mein.of Biochem. Analy. 14, 63-77, 1966). Detection limits of the system are in the range of $0.05 \mu \mathrm{g}$ cortisol per ml fluorescence reagent. The procedure requires 0.2 to $0.4 \mathrm{ml}$ of serum or plasma and has the advantage that the reagent blank, reference solutions, and unknowns can all be analyzed simultaneously. This is an important feature for time-dependent fluorescence assay systems such as the cortisol analysis. EDT A-titrimetric analysis of serum calcium using calcein as an indicator and the direct analysis of serum calcium using calcein have been compared by performing both types of analysis simultaneously in one rotor. Analytical agreement between the two procedures of $\sim 1 \%$ was obtained using a $9.0 \mathrm{mg} / \mathrm{ml}$ serum control sample. A discussion of the analyzer and the analyses will be presented.

1. Abstract of paper presented at the 24th National Meeting of the American Association of Clinical Chemists, Cincinnati, August 20-25, 1972.

2. MAN Program. 


\title{
7.19 A RETROREFLECTIVE FIBER OPTIC TURBIDIMETER FOR CONTINUOUSLY MONITORING FERMENTATION'
}

\author{
L. H. Thacker E. F. Plares ${ }^{2}$ \\ $\begin{array}{lll}\text { W. F. Joinnson } & \text { C. W. Hancher } & \\ & \text { A. D. Kelmers } & \end{array}$
}

A retroreflective fiber optic turbidimeter has been developed to automatically and continuously assay the cell concentration in a fermenter by measuring the turbidity of the solution as a function of the light scattered at $180^{\circ}$ to the incident light. The outpur signal is nearly directly proportional to the cell concentration of a fermenter sarnple stream containing wet weights from 0 to over $50 \mathrm{~g}$ of cells per liter. The device consists of a bifurcated fiber optic light-pipe, with its distal end inserted into a flow cell through which the material to be analyzed passes. A light source on one proximal branch of the lightipipe illuminates the sample stream; light back-scattered from particulates in the stream reenters the light-pipe and is returned to a photodetector on the other proximal branch of the light-pipe. 1 signal conditioning system connected to the optical head by a cable provides gain and zero adjustment.

1. Abstract of paper to be submitted for publication in Biotechnology and Bioengineering.

2. Biology Division.

3. Chemical Technology Division.

\subsection{DEVELOPMENT OF A MINIATURE FAST ANALYZER ${ }^{1}$}
C. A. Burtis ${ }^{2}$
W. F. Johnson
J. C. Mailen ${ }^{2}$
C. D. $S \operatorname{cott}^{2}$
T. O. Tiffany ${ }^{2}$

Design features and operation of a prototype miniaturized Fast Analyzer are described, and some results obtained with it are presented. The Analyzer occupies only $1 \mathrm{cu} f \mathrm{ft}$ of space. It has a 17-cuvet plastic rotor which rotates through a stationary optical system at speeds up to $5000 \mathrm{rpm}$. The resulting centrifugal force is utilized to transfer and mix a series of sample(s) and reagent(s) into the cuvets. The ensuing reactions are monitored spectrophotometrically, and the data are evaluated in real time by an on-line computer. Samples ( 1 to $10 \mu \mathrm{l}$ ) are loaded into the rotor either discretely or dynamically; various rotor configurations can be used to do this. Many of the standard clinical analyses, including most of the NADH-linked enzymatic analyses, have been adapted for use with this analyzer. Precision obtained ranges from 1 to 4\%. This report considers, specifically, analyses of some serum enzymes. Results show that the small analyzer possesses the previously demonstrated advantages of Fast Analyzers and, in addition, has several beneficial features arising from miniaturization.

1. Abstract of paper submitted for publication in Clinical Chemistry.

2. ORNL Molecular Anatomy Program.

\subsection{DEVELOPMENT OF A PORTABLE DATA PROCESSOR WITH MECHANICAL DATA OUTPUT FOR USE WITH A MINIATURE FAST ANALYZER'}
W. F. Johnson
J. C. Mailen ${ }^{2}$
C. A. Burtis ${ }^{2}$
T. O. Tiffany ${ }^{2}$
C. D. Scott ${ }^{2}$

The Mark I data processor is a system for acquiring, processing, and printing, with the aid of a computer, the results of analyses carried out in Fast Analyzers. Because it is inexperisive and portable, this system is particularly applicable for use with a newiy developed miniature Fast Analyzer. It utilizes digital logic to correlate the signals originating at the photodetestor of the analyzer with the proper cuvet position and corresponding recorder channel. The transmission pulses are converted electronically to absorbance values, which are recorded as printed dots on a data card. Vertical height on the card is proportional to absorbance, with the maximum absorbance and the absorbance span to be covered being set by calibrated 
potentiometers. The Mark 1 data processor has been evaluated in parallel with an on-line computer. and data obtained from it correlate with the computer-derived data.

1. Abstract of paper to be published in Clinical Chemistry.

2. ORNL Molecular Anatomy Program.

\title{
7.22 AUTOMATED SAMPLE-REAGENT LOADER FOR USE WITH THE GEMSAEC FAST ANALYZER'
}

$$
\begin{array}{lll}
\text { C. A. Burtis } & \text { W. F. Johnson J.C. Mailen } & \text { J. E. Attrill } \\
&
\end{array}
$$

With a newly developed autumated sample-reagent loader for use with a GeMSAEC Fast Analyzer. a 15-place GeMSAEC transfer disk can be automatictily loaded with reagent and samples in 3.25 min: manual loading methods required $15 \mathrm{~min}$. The resulting precision and accuracy is equai to or better than thai for manuai methods of loading. Sample carryover of th: system was decreased. and is about $1 \%$.

1. Abstract of published journal article: Clin. Chem 8 (5). 433 (1972).

2. ORNL Molecular Anatomy Program.

\subsection{A NEW SENSITIVE ULTRAVIOLET DETECTION SYSTEM FOR CARBOHYDRATES ELUTED DURING COLUMN CHROMATOGRAPHY'}

\author{
Sidney Katz ${ }^{2} \quad$ L. H. Thacker
}

A simple and sensitive detection system has been developed for carbohydrates eluted from chromatographic columns. The new system relies on the production of an ultraviolet absorbing chromophore by dynamic reaction of the carbohydrate in the eluent solution with sulfuric acid. The chromophore has a broad absorption band in the ultraviolet, with a peak at $296 \mathrm{~nm}$ and a minimum near $254 \mathrm{~nm}$. Because of its sensitivity, simplicity, and operational durability, a modification of the previously reported $^{3,4}$ miniature dual-beam photometer with two fixed wavelengths was used as the detector. The 254-nm channel was retained to help identify norcarbohydrate compounds, and a $\Xi 06-\mathrm{nm}$ char.nel was substituted for the original $280-\mathrm{nm}$ channel to detect carbohydrates. Wavelength conversion filters were developed to provide a peak effective transmittance at $306 \mathrm{~nm}$ with a bandwidth at half maximum of 41 $\mathrm{nm}$, coge iher with conversion of the ultraviolet radiation to visible light for detection by conventional photoconductors.

The new system is operationally simpler than any of the existing systems for the detecticn of carbohydrates in eluents, and the sensitivity is as good as any previously reported.

1. Abstract of published journal article: J. Chromalog 64, 247-52 (1972).

2. Chemical Technology Division.

3. L. H. Thacker et al., "A Miniaturized Ultraviolet Flr - Photomet vr for Use in Liquid Chromatographic Systems." J. Chromalog 51, 175-81 (1972).

4. L. H. Thacker et al., "Miniature Photometers for Liquid Chromatography." Clin. Chem. 16, 626 (1070).

\subsection{LASER OPTOELECTRONIC SYSTEM FOR PROJECTILE VELOCITY MEASUREMENT}

\section{H. Thacker}

An optnelectronic system, using a $2-\mathrm{mW}$ helium-neon laser for a light source, was develcped for measuring the velocity of radioactive test specimeris fired toward a rigid wall by a compressed air gun. The system will be used in-cell to evaluate isotope fuel element composites in terms of their ability to withitand reentry in to the earth's atmosphere from space.

The beam from the laser is divided by a heam splitter and prism to cross the projectile path at two locatioris $1 \mathrm{ft}$ apart. Silicon photovoltaic cells sense sequential internuption of the two beams, and ampliited 
output pulses provide start and stop signals for a $100-\mathrm{kHz}$ interval timer. Time measurements over the

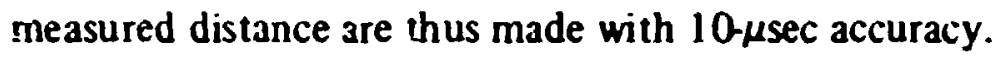

Evaluation tests by the Isotopes Division show almost perfect correspondence with high-speed photographic data taken for comparison.

\subsection{DEVELOPMENT OF SECOND-GENERATION MINIATURE FAST ANALYZER SYSTEM}

W. F. Johnson

After siveral months of operation of the Mark I miniature fast analyzer system, some areas need improvement, and these changes were incorporated in the Mark II system. The Mark II analyzer module contains a rotor temperature monitoring and control system, a larger rotor drive motor with an attached electromechanticai breke, an automatic high-voltage control for the photomultiplier tuve, an improved light source, and a magnetically shielded holder for the photomulciplier tube. This module, even with all these additions, is still housed in the same 8-in.-high, 6-in.-deep, and 10-in.-wide instrument cabinet. This unit is the most precise fast analyzer produced at ORNL; its precision, without signal averaging, is 0.0004 absorbance unit.

The Mark II data processor module imprcvements include an internal logarithmic amplifier, individual maximum absorbance and absorbance span adjustments for each of four sets of four cuvets, an internal clock for controlling the automatic transfer and mixing in the analyzer module, improved printing solenoids, and a much faster scanning speed.

\subsection{A MINIATURE FLOW FLUOROMETER FOR UQUID CHROMATOGRAPHY'}

\section{H. Thacker}

A miniature flow fluorometer has been developed for use as a detector in liquid chromatograph systems. Excitation wavelengths can be chosen among the low-pressure mercury lines by a choice of filters: err sssion wavelengths between 310 and $650 \mathrm{~nm}$ can be observed, and the accepted emission spectrum can be limited by blocking filters. The instrument is presently in use in the Body Fluids Analyses Program of the Oak Ridge National Laboratory in a new system developed to monitor classes of compounds previously difficult to detect in chromatograph eluates. In this service the new instrument will detect well-separated organic acids present to the extent of $100-500 \mathrm{ng}$ in the injected sample.

1. Abstract of paper submitted for publication in Journal of Chromarography.

\subsection{STANDARDS LABORATORY SERVICES}

\section{W. W. Johnston, Jr. M. H. Cooper, Jr. J. L. Horton W. H. Williams}

A significant amount of time was devoted to the development of quality assurance (QA) procedures. This effort is a continuation of previously reported ${ }^{1}$ work, and includes evaluation of the basic capability of the S a andards Laboratory. Plans for upgrading measurements are being formulated that will include expansion of the physical facilities and acquisition of aciditional precision standards to meet the increased requirements of the OKNL QA program.

ORNL research projects were assisted through consultation and development of instruments and equipment in several areas. A. major task was the design, development, and operation of a test facility for testing irradiated thermocouples for the FFTF thermocouple program. The apparatus set up in the Thorium-Uranium Recycle Facility included remote assembly of thermocouples and homogeneity, 
calibration. time response, and thermal cycle tests. Special thermocouples and high density heaters for FFTF tests under the LMFBR program were designed. procured and tested.

A high-temperature, Roux-type drop calorimeter was designed and built for the desalination program. Its sensitivity is better tian $0.01^{\circ} \mathrm{C}$ at temperatures to $1000^{\circ} \mathrm{C}$.

In other assistance, more than 300 precision standardizations on temperature, electrical, pressure. frequency, and time instruments and sensors were completed.

1. M. H. Cooper and W. W. Johnston, Jr., Instrumentation and Controls Div. Annu. Prozr. Rep. Sept. 1, 1971. ORNL-4734. pp. 55-58.

\title{
THERMOMETRY PROGRAMS
}

\subsection{NEW THERMOCOUPLE CHARACTERISTICS CONFORMING TO IPTS-1968 ${ }^{1}$}

\author{
R. L.Simpson R. K. Adams
}

The functions defining the characteristics of six types of thermocouple materials were received from the National Bureau of Standards (NBS). These functions were compared to the OPNL smootined thermicesipie tables ${ }^{2}$ (which had been corrected to IPTS-1968) to check their crnformity with the NBS-fitted functions. Also, the first and second differences were plotted to check for smoothness and discontinuities. Severai discrepancies were found and reported to NBS, which resulted in improved functions.

Subroutines were prepared to calculate and print the new tables in ${ }^{\circ} \mathrm{F},{ }^{\circ} \mathrm{C}$, or ${ }^{\circ} \mathrm{K}$. These subroutines were constructed so that they can be used in programs where the previous thermocouple tables were required.

1. R. L. Simpson and R. K. Adzms, "The International Practical Temperature Scale of 1968," Merrologia 5(2), 35 (April 1969).

2. R. K. Adams and E. G. Davisson, Smoothed Thermocouple Tables of Extended Significance, ORNL-3649, vol. 2 (March 1965).

\subsection{LMFBR TEMPERATURE SENSOR DEVELOPMENT}

\begin{tabular}{|c|c|c|}
\hline \multicolumn{3}{|c|}{ N.B. Herskovitz } \\
\hline K. R. Carr & J. M. Chandler ${ }^{1}$ & W. Dalos 2 \\
\hline N. C. Hoitink ${ }^{2}$ & J. H. Holladay & J. L. Horton \\
\hline H. H. Hubbell & J.N. Kelley ${ }^{3}$ & W. W. Johnston, Jr. \\
\hline C. A. Mossman & $\begin{array}{l}\text { J. L. Redfourd } \\
\text { C.B. William }\end{array}$ & H. J. Wallace ${ }^{4}$ \\
\hline
\end{tabular}

Temperature development work for the Liquid-Metal Fast Breeder Reactor program was continued. 5 The work included an evaluation of the performance of fast-flux-irradiated, metal-sheathed thermocouples; large-scale procurement of thermocouples for the Fast Flux Test Facility (FFTF) and related programs; an evaluation of single- and dual-element platinum resistance thermometers; a study of thermometer readout systems; and consultation, service for FFTF and LMFBR research and development programs. The most important technical finding was that Chromel-Alumel thermocouples exposed to the simulated FFTF neutron flux and temperature environment were not significantly damage : The thermoelectric irhomogeneity patterns along the irradiaied thermocouples reflected the temperature and neutron flux distribution 
in the reactor and also indicated temperature annealing of neutron damage in areas of both high flux and high temperature.

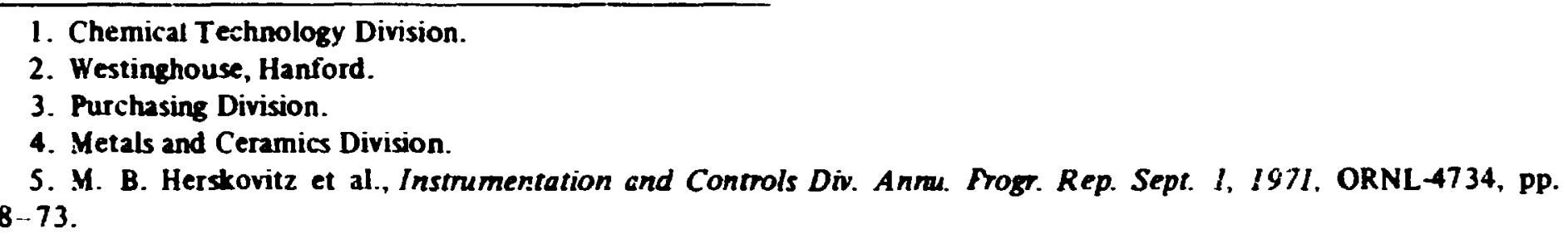

\subsection{TESTING OF IRRADIATED CHROMEL-ALUMEL THERMOCOUPLES}

$\begin{array}{lll} & \text { J. H. Holladay } & \\ \text { K. R. Carr } & \text { J.M. Chandler } & \text { W. Dalos } \\ \text { M. B. Herskovitz } & \text { N. C. Hoitink } & \text { J. L. Hortr.n } \\ \text { W. W. Johnston, Jr. } & \text { C. A. Mossman } & \text { H. J. Wallace } \\ & \text { C. B. Williams } & \end{array}$

The testing of type-304, stainless steel sheathed, MgO insulated, Chromel-Alumel thermocouples irradiated in a fast flux (environment) is a jeint project of ORNL and Pacific Northwest Laboratories (PNL). CRNL prepared a specification for high-reliability thermocouples, 1.S. 509-4 (a predecessor to tie current RDT Standard (7-6), purchased assemblies to proof test the specification, and perforned certain preirradiation tests. PNL completed the preirradiation tests and tested the assemblies (runs 46A to 50F from Sentember 10, 1970, to August 15, 1971) after their irradiation in the Experimental Breeder Reactor II (EBR-11). These thermocouple assemblies were made by three manufacturers and were of two types: (1) manufactured by a swaging process, and (2) manufactured by a drawing process. We expected performance differences to indicate if one process were superior to the other.

While the thermocouples were being irradiated, an agreement was reached that ORNL would perform the postirradiation tests. The thermocouples included 26-in.-long units which had experienced $\sim 10^{22} \mathrm{nvt}$ fast-neutron exposure $(>0.1 \mathrm{MeV})$ at $1200^{\circ} \mathrm{F}$ and centered on the junction, and 52-in.-long assemblies in which the peak flux and temperature occurred at approximately the center of the thermocouple length. Following irradiation in the EBR-11, the thermocouples were shipped to ORNL for postirradiation tests. The tests were conducted at the Thonium-Uranium Recycle Facility (TURF, Building 7930).

Special fixtures and jigs were designed and made to remotely install thermocouple plugs. Originally, 12 thermocouples were cleaned and connectors installed remotely, but one spot-welded connection broke and three thermocouples were held for future tests. So two th:rmocouples from each iff the manufacturing groups were tested, a total of eight.

Eight thermocouples were cleaned, and connectors were installed remotely. Tests for loop resistance, insuiation resistance, changes in sheath diameter, and time response were satisfactory, as compared with preirradiation tests. The emf vs temperature calibration test results from 200 to $1200^{\circ} \mathrm{F}$ were within accentable limits. Seven thermocouples were subjected to thermal cycling tests in which the temperaiure was increased and decreased between 1245 and $\sim 745^{\circ} \mathrm{F}$ at a rate of $100^{\circ} \mathrm{F} / \mathrm{sec}$. All siven thermocouples survived more than 3000 cycles without failure. Survival of 3000 cycles is a performance goal for the thermocouples to be used in the Fast Flux Test Facility' (FFTF).

Testing for thermoelectric inhomogeneity was dune on the irradiatec thermocouples. To our knowledge, this is the first testing of this type on irradiated therr. Iccouples. The inhomozeneity of a test thermocouple was measured by recording the differential output of the test and standard thermocouples as both were inserted into a $300^{\circ} \mathrm{F}$ salt bath. In this test, the temperature gradient was $\sim 200^{\circ} \mathrm{F} / \mathrm{in}$. The 
resulting data record provides an indication of the themuelectric properties of th. test thermocouple along its entire lengtit. Since the irradiation and temperature experience of the test thermocinples is also known, the inhomogeneity data provides information on the damaze to Chromel-Alumel after service at various irradiation and temperature levels. The entire :est group was initially tested for inhomogeneity before any of the thernocouples were aged, so that the irradiation and temperature effects would be clearly defined.

A typical data record is shown in Fig. 7.30.1: the irradiation and temperature service of the thermocouple are also inciuded. A surprising result was that the section of thermixcouple exposed to the highest temperature and irradiation showed the least damage. We suspert that the high temperacure, near the midpuint of the 52-in. thermocouple and at the jinction of the 26 -in. the mocouple, had annealed tire therm:oelement metals and eliminated the neutron damage. This $p$ suibility was confirmed when two therm cotiples were annealed fo: $10 \mathrm{~min}$ at $1800^{\circ} \mathrm{F}$ and all traces of inhomogenetty were stiminated. Furthis tests on another thermocouple revealed that the inh omogeneity was partialiy annealed after $10 \mathrm{mi}$, at $1400^{\circ} \mathrm{F}$

A portion of the toial test group was placed in an environment that simulated the tenperature experience of the irradiated group, but without fast-flu: irradiation. The purpose was co obtain information

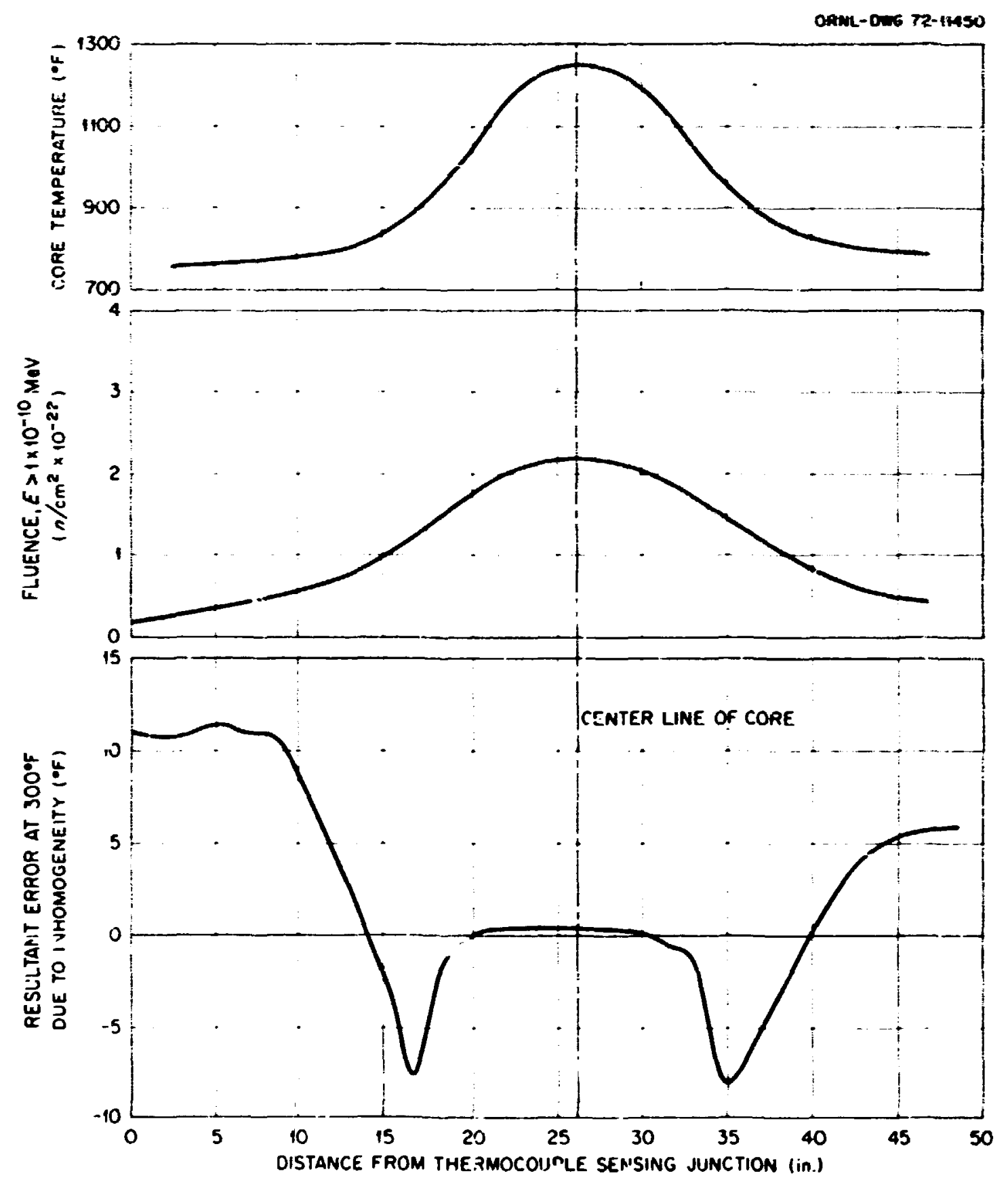

Fig. 7.30.1. Typical resultant thermoelectric inhomogencity error related to the irradiation fluence and core temperature. 
on the relative efiects of temperature atune and of combined temperature-irradiation. The intomogeneity tests on the group that had been subjected to temperature aloate indicated that these thermoccuples dij not show any effects of inhomogeneity caused by thermal soaking.

Connectors were installed on 12 additional thermocouples in the hot cell, and tests were madi to determine the themoelectric homogeneity of the thermocoupl: wires. The resilts were similar to the previous satisfactory tests on the fint eight thermocouples.

To determine if thermoelectric inhomogeneities caused by neutron flux could be eliminated by annealing a thermocsupie in the reactor, further tesis were made. The sheath was heated to $1200^{\circ} \mathrm{F}$ (operating temperature of the FFTF), and sufincient electrical current was passed through the Chromel-Alumel wires to heai sic wires an additional $600^{\circ} \mathrm{F}$. This is comparable to heating the shesth to $1 w^{\circ}$ In in the firsi annealing test. Results showed that this indirect method of annealing removed all traces of inhomogeneity, indicating is.at hermoelectric inhomogeneities in the thermocoupls resulting from neutron flux could be eliminated without shutting down the reactor.

The results from the hot-cell tests indicate that Chromel-Alumel thermocouples, with the proper quality assurance, will be adequate for the intended FFTF use and also that

1. None of the products from the three manufacturers tested showed a clear superiority to one another.

2. Neither method of sheath production (drawing or swaging) in the test group showed a clear superiority to one another.

Further tests will be sonducted to determine which of the thermocouple wires (Chromel or Alumel) contribute most io the observed thermoslectric inhomogeneity. For these tests, some of the existing insulated-junction thermocouples will be converted to grounded-junction thermocouples by remote methods in the kot cells of the TURF.

1. Chemical Technology Division.

2. Westinghouse, Hanford.

3. Metals and Ceramies Division.

\subsection{LARGESCALE PROCUREMENT OF TEMTERATURE SENSORS}

\section{$\begin{array}{llll}\text { M. B. Herskovitz } & \text { J. N. Kelleyy' } & \text { C. A. Mossman } & \text { C. B. Williams }\end{array}$}

This program is intended to provide high-quaity Chromel-Alumel thermoccuple assemblies, insulated with $\mathrm{MgO}_{\mathrm{g}}$, and sheathed in type-304 stainless steel for the Fast Flux Test Facility (FFTF) and for research programs related to the Liquid-Hetal Fast Breeder Rexctor (LMFBR). The most reliable bulk material available will be obtained in $10,000-\mathrm{ft}$ lots of $1 / 2$ in. OD and 500-ft luts of $1 / 16$ in. OD bulk material. Materi. is are being obtained from one manufacturer who swages the sheath and a second order was places with a manufacturer who draws the sheath to the desired outside diameter.

Each of the users in the LMFBR programs his estimated an annual usaze of thermocouple assernblies, and procurement is based on these astimates. The finished oulk material will be stored in a "crntrolled" area at the manufacturers' plants; and, as the users order 'ssemblies, ORNL will ensure that the order: are filled from the stored bulk. material. This storage of material will reduce thic lead time to delivery of material from months to weeks. As an example, in response to an urgent requirement by the Liquid Metals Engineering Center (LMEC), thermocouple assemblies were delivered within four working days after thi needed material was requested and the crder approved.

A procurement plan was prepared (Sect. 7.47), and a "request for bids" was advertised. Bids wise received from seven inanufacturers. Assista. ce was obtained frcm other groups in the Instrumentation and 
Controls Division and from the Metals and Ceramics Division, the Inspection Engineering Department, and from the ORN1. Quality Assurance Program to evaluate the capabilities of these manufacturers.

One manufacturer started profuction in July, with an ORNL inspector observing the work. Final acceptance of bulk material will follow testing at ORNL. A revolving account will be established to obtain reinibursement funds when thermocouple orders from users are filled. The second manufacturer started production in Septrmber.

1. F strchasing Division.

\subsection{THERMAL SOAI OF THERMOCOUPLES}

\section{J. L. Horton}

As part of the FFTF-LMFBR thermocounle test prozram, samples from each group of thermocouples procured for irradiation in the EBR-II were subjected to temperature conditions comparable iv uhase for irradiated thermocouples so that temperature effects could be separated from irradiation effects.

Four 'zoups of thermoccuples, 53 in each, had been procured $\mathrm{fc}_{\text {i }}$ th: iotal cest program. Thic thermocouples in two of these groups rere manufactured by swaging and those in the other two by drawing. Twenty-five thermocouples from each group were irradiated in the EBR-1i.

For thermal soaking without irradiation, seven thermocouples from each of tine four groups were subjicied to temperatures, gradients, and cycles comparable to those actually experienced by the irradiated thernocnuples. When the EBR-II was at full power, the 26-in.-long thermocouples experienced a gradient from $1200^{\circ} \mathrm{F}$ at the junction end to $700-750^{\circ} \mathrm{F}$ at the leadwire end. At zero reactor power, the thermocouples remained at $600-700^{\circ} \mathrm{F}$ throughou, their lengths.

To simulate the reactor gradient, a 54-in.-long, 2-in.-bore furnace with a nine-section heater winding was used. Heater sections were shunted or deleted to obtain a gradient that matched the EBR-II. The thermocouples weie mounted inside a stainless steel container, and the container was evacuated and then pressurized to 5 psig with helium. To simulate conditions at reactor full power, the container was pushed into the furnace such that the thermocouples being tested experienced the 1200 to $720^{\circ} \mathrm{F}$ gradient. To simuiate conditions at reactor zero power, the container was withdrawn to the uniform $720^{\circ} \mathrm{F}$ zone.

These thermocouples were soaked for $2731 \mathrm{hr}$ in the simulated full-reactor-power gradiunt, with 51 withdrawals to simulate reactor shutdown. This thermal soaking without irradiation approxinated the temperature history which the irradiated thermocouples acquired, as asceriained from EBR-II operations reports.

These thernocouples will be tested by the same procedure as the irradiated thermocoiples.

\subsection{FAILED FUEL MUCKUP THERMOCOURES}

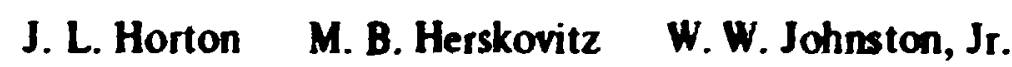

The FFM, which is a program for evaluating the consequences of blocked flow of sodium in the cooling system for the Fast Flux Test Facility (FFTF) core, required special 0.056-in.-OD, sheathed thermocouple assemblies, as previously reported.' Two manufacturers supplied a total of 107 dual, insulated-junction assemblies and a total of $4 i$ dual. grounded-junction assemblies. Fach assembly required testing to assure that it met FFM requirements.

Difficulties were encountered with the dual, grounded-junction assemblies from both manufacturers, i.e., wire sizes. junction identificat on, and location of wire-to-sheath welds. The FFM requires that the 
0.007 -in.-diam thermocouple wires be welded to the inside of the 0.036 -in.-1D sheath $\sim 0.060$ in. from the end of the sheath and that the juncticns formed by the four wires be radially opposite within $\pm 5^{\circ}$. This is a most stringent tolerance in both fabrication and verification of the finished assembly.

A jeweler's lathe, a thermocoupte support rack, a pencil soldering iron with a specially machine ${ }^{2}$ tip for a fine-point heat source, and a two-pen recorder for readout were set up for testing the assemblies.

$A$ iarge number of the zrounded-junction assemblies were un:acceptable and are to be reworked by the manufacturer. A new drawing with altered specifications was repared, and the manufacturers' phants were visited to nssolve assembly difficulties.

1. M. B. Herstovitz et al, Instrumentation and Controls Dir. A num Prop. Rep. Sept. 1, 1971, ORNL-4734, p. 71.

\section{T.34 THERHOCOLAL ESULATION RESTSTANCE}

\section{J. L. Horton}

Tests were performed to determine the insulation resistance vs temperature for typical 0.125 -in.OD, sheathed, MgO insulated thermocouple material of the type specified for the FFTF-LAFBR usage. Also of interest was the difficulty of driving moisture from the $\mathrm{M}_{1}, \mathrm{O}$ insulation of fabricated material.

Nine 12-in.tong samples of material from thermocouples procured over ine past three years from five different manufacturers mere heated repeatedy from near room ismperature to $1000^{\circ} \mathrm{C}$ by passing an $x$ current through the sheath. The sireath temperatures were measured by 0.005 -in. OD Chromet-Alumel wires spotwelded to the sheath. Insulation resistance vs temperature was recorded with a logarithmic chmmeter $\left(90 \mathrm{~V} \mathrm{dc}\right.$ ) and an $x \cdot y$ recorder. At $25^{\circ} \mathrm{C}$, newly dried specimens initially measured $10^{\circ}$ to $10^{11} \Omega$, but older specimens, obviously with some water absorbed in the M8O, measured as low as $10^{5} \Omega$ at $25^{\circ} \mathrm{C}$.

The insulation resistance of all specimetas progressively increased with each heat cycle. Each specimen was cycled repeatedly until its maximum resistance is temperature reading were oblained and repeated from cycle to cycle. The pumping action of repeated cycling with both ends open was found to be required. Figure 7.34.1 shows a composite of all measurements, i.e., wire-to-wire and wire-to-sheath after a maximum rusistance was ubtained, as well as measurements for three specimens after a single heating cycle.

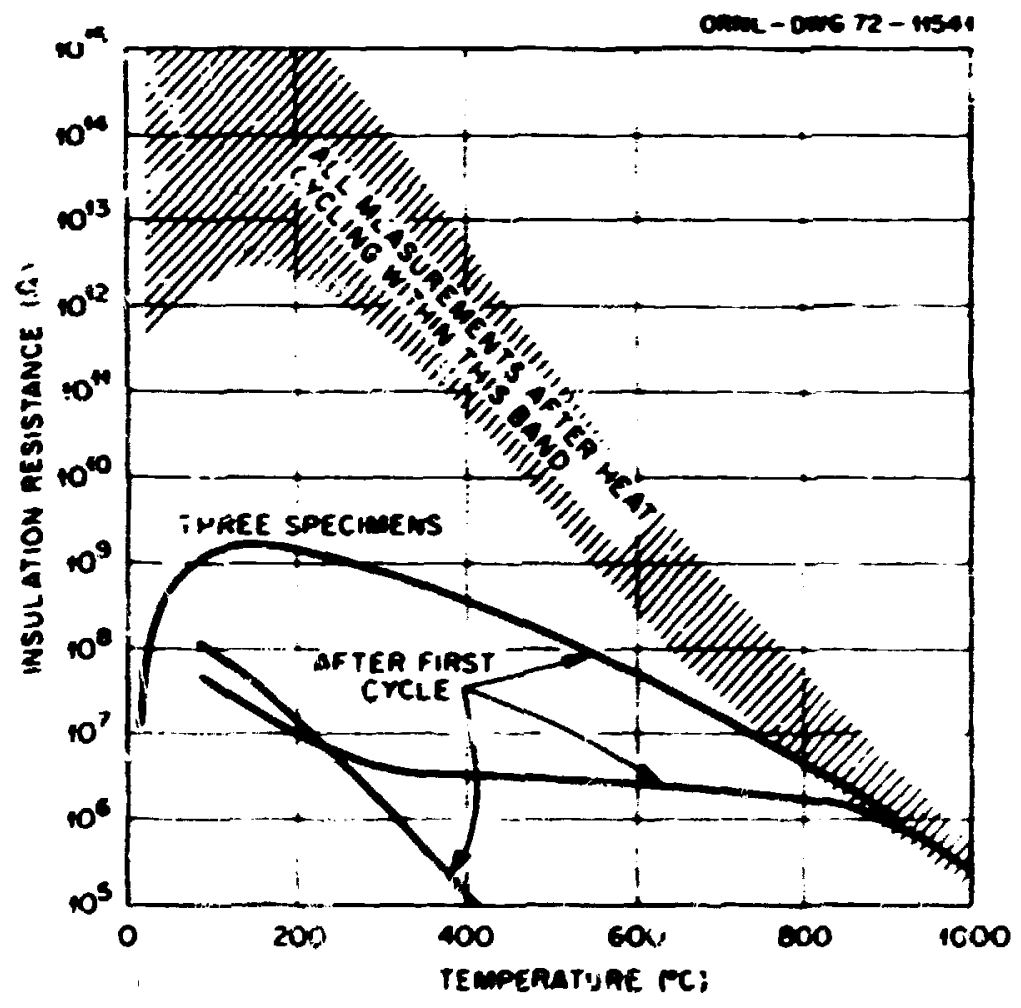

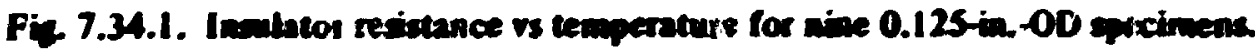


It was ir.possible to drive all mosturc by sheath resi itance heating from an assembly that had one end closed, because moisture was trapped in the cooler. closed end.

The results of these tests verify that dry material from all vendors should have a high insulation resistance. If the material is kept dry and clean, no difficulty should be encountered in meeting procurement specifications. Also, moisture can be driven from the $\mathrm{MgO}$ insulation to restore high insulation resistance by repeated cycling at a sufficiently high temperature and with adequate venting.

\subsection{THERMOELECTRIC THERMALGRADIENT SENSOR}

\section{K. R. Carr}

The design, constniction, and initial testing of a prototype thermal gradient sensor was completed. It will be used to aid in the test work in the LMFBR Temperature Sensor Progran. The sensor is similar to conventional sheathed thermocouples except in two instances: (1) it contains nine lengths of thermoelectra: wire rather than two, and (2) the sensing junct:ons are made before assembly so that they can be located along the senser length. The protorype is $\sim 1 / 4$ in. $O D$ and can measure eight temperatures at locations along its length.

In general, this new design needs only $n+1$ lergths of wire to measure $n$ temperatures, compzred with $2 n$ lengths of wire required by conventiona' thermocouples. The fewer wires required allows a heavier sheath wall. more insulation, or barger thermcelectric wirtes to obtain better performance and additional temperature measurements in a given stiath diameter. Other advantages are ease of mounting and tight, well-defined thermal coupling of the sensing junctions to the outer sheath and to each other.

The new design is being considered for use in a fuel evaluation experiment scheduled for January 1973 in the High Flux Isotope Reactor (HFIR). In this application, the outside diameter of the sensor sheath will be limited to $\sim 1 / 16$ in., and the number of sensors which can be used will be iimited by the available wall penetrations. Additional temperature measurements will be desired which cannot be made with converticinal thermocouples. Therefore, the uew sensor design potentially can appreciably increase the information output from the experinent.

\subsection{PLATINUM RESISTANCE THERMOMETERS}
K. R. Car,
M. A. Herskovitz
H. H. Hubbell
R. K. Adams
J. L. Horton
C. A. Mosst an

An extersive program was continued to study virtually all aspects of platinum resistance theñometers (PRT's) and associated readout equipment. The immediate primary purpose of the program is to provide reliable and very accurate (state-of-the-art) thermometers for heat balance measurements in tive Fast Flux Test Facility (FFTF). The effort has included testing of both industrial thermometers and innovative designs. writing and purchasing to an RDT specification, evaluating manufacturers, and providing assistance in the selection of themometer readout equipment for the FFTF.

The industrial thermometers produced by several manufacturers were tested to determune performance Im:sis un: ais.table for FFTF service. Ihe results of the testing vere utilized to write a revised progr am work plan and a first draft of RDT Standard C7-17 for platinum resietance thermumeters.

As palt of the prepuration of the draft copy of RDT C7.17. thermometer manufacturers were surveyed and evaiuated. Approximately 15 visits were made to observe the manufacturing techniques and capabilities of every leading themometer manufacturer in this country. From discussion $1: i$ ing these plant visits, we learned to idensify critical items that should $b$, included in a specification for thermometers for use in nuclear reactors, such as component specificatiors and construction techiliques. 
The evaluation of several mar.ufacturers will continue as thermome ers procured in accordance with RDT 07.17 are tested. Approxinately 120 manufacturers were inwited to bid, and 12 manufacturers submitted bids or proposals. A total of 128 thermometers are being purchased from eight manufacturers. The survey and evaluation indicates that there are not more than about seven to ten manufacturers in the United States that are capable of producing high-quality platinum resistance thermometers required for the FFTF.

Emphasis in the program is now on dual-element thermometers (two electrically independent lengths of resistance-sensing wire in the same sheath), because the ni-mber of piping penetrations for thermowells in the FFTF was reduced and redundancy of these important temperature measurements is desired. Since manufacturers' usual products generally do not meet the application requirements of relatively small sensor size ( $\sim 3 / \mathrm{h}$ in. OD), eight lead wires, and operation to $1200^{\circ} \mathrm{F}$, testing of some prototype designs will be scheduled. There are little or no long-range-performance data of PRT's at $1200^{\circ} \mathrm{F}$ for the usual products of manuíacturers.

Available methods of displaying and recording thermometer outputs were studied. Since the output of a platinum resistance thermoneter is not linear with temperature, some signal conditioning is necessary for convenient readout of the signal. From this study, the system recommended for the FFTF is use of a dual-element thermometer at each location, with readout of one of the dual elements by an industrial transmitter and digital voltmeter and readout of the other element by an automatic data acquisition system. A report of this work was nrepared.'

A need fin redundancy of temperature measurements in some afplications has resulted in development of a new sensor having combined resistance thermometer and thermocouple outputs. Several experimental sensors were built. One design has a dual-etement assembly, and a type-S thermocouple is attached to each end of each of the two elements. A $\bar{z}_{\mathbf{z}}$-in.-OD sensor, therefore, yields twu independent platinum resistance thermometer outputs and four type-S thermocouple outputs. In addition to this redundancy, this sensor is also useful for basic studies to compare the stability and accuracy of the therriometers ard thermocouples, and tests of this type are planned.

1. I. L. Horton, K. R. Carr, and R. K. Adams, Recommendation of a Readout Syseen for Accurce FFTF Plativum Ther momerer Process Temperature Messuremenss, ORNL TM-3937 (to be published).

\subsection{EXAMINATION OF THERMOCOUTES IN SODIUMHEATED STEAH GENERATOR}

\section{J. H. Holladay M. B. Herskovitz}

An investigation was made to explain the large number of thermocouple failures in the ALCO/BLH unit to obtain information necessary for improviag thermocouple materials selection, installaion and assembly methods, penetration designs, and reference-junction terminations.

As part of the LMFBR program, tesis were started by the Liquid Metals Engineening Center (LMEC) in January 1966 on the ALCO/BLH unit, a soaled-down prototype of a sodium heated steam senerator. The tests were itopped in May 1970 because there was leakage in the vicinity of the feedwater header. ORNL began to examine the steam generator in December 1970.'

The prototype was originally equipped with $\sim 100$ thermocouples to measure intemal fluid temperatures and structural surface temperatures. The internal thermocouples were sheathed with Inconel on the water (steam) side of the unit and with stainless steel on the sodium side. Most of the internal thermocouples had failed in February 1970 during operation of the steam werator with a high sodium-inlet temperature, low-heat-translet performance, a high hydrogen concentration in the cover gas, and a high sodiun piugging temperatu:e. 
The main cause of thermocouple failure was (1) corrosion within the hydrogen cover-gas region due to a water leak. and (2) burn through on the sheaths where a thermocouple had been welded to a pad and the pad assembly subsequently had been welded to the inner surface of the steam generator. Some thermocouple wire breakage was also observed at the weld points.

The corrosion could be minimized by immersing the therrnocouples and sheaths in the sodium to the point of exit from the steam generator. How to make proper welds to the sheath without burn through and wire breakage of the thermocouple wires will be studied.

1. G. M. Sbuchter and J. H. DeVan, Interion Informetion Report on Postrest Examintion of ALCO/BLH SadiumHeoted Stem Generetor. ORNL TM-3636 (May 1972).

\subsection{IN SITU THERMOCOURLE TESTING}

\section{R. M. Carndl}

Previous studies' of in situ thermocouple testing were continued with the resumption of tests of methods for electrical self heating of the thermocouptes. In earlier work we discharged a capacitor into the thermacouple to heat it, but a disadvantage if this method is that the current source decreased exponentially as the capacitor discharged. Calculations showed, however, that the temperature rise at the thermocouple junction would be significant and that an analysis of the sooling rate of the junction after heating would yield an insight inte the integrity of the junction.

New experiments, using a de constant-current source, showed that the temperature rise of the theimocouple junction was influenced by the direction of the current (depending on whether the Peltier effect was aiding or opposing the resistance Joule heating), as well as by the heat transfei from the junction and sheath. In the experiments the emf of the thermocouple was recorded, starting about $0.02 \mathrm{sec}$ after the heating was stopped. The analysis of the cooling rate is expected to yield siznificant information about the thermal coupling of ihe thermocouple insulation to the junction and the sheath in addition to information sbout the coupling between sheath and process.

A great advantay of this method is that it $\mathrm{can}$ be used on thermocouples before, during and after irradiation. Espaially, the technique is promising as an on-line surveillance method to measure the time response of thermocoupies instolled in experiments and reactors for process and safety control. Improvements in the excitation and response instrumentation ars being made so that further refinement and quantization of the method will be possible.

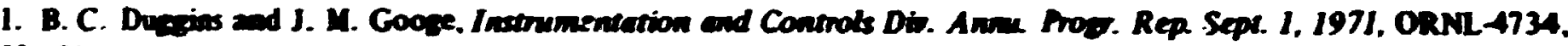
pp. 52-55.

\subsection{TUNGSTEN-BHENIUM ALLOY EVALUATION FOR HIGH TEMTERATURE THERMOMETRY}

\section{R. L. Shepard R. M. Carroll}

A joint project between Oak Ride National Laboratory (ORNL) and the viaional Bureau of Standards (NBS) was established to investignte the effecis of thenium proportions in W-Re alloys for thermal sensors. A contract was ptaced with a vendor to make allo;s with 13 different proportions of itenium into 0.015-is.-diam wire. Segments of the same wire rolls wil be examined by both ORNL and NBS, and dats will be shared to reduce duplication of effort. In gemeral, O?NL will study velocity-of-sound and irratiation effects, and NBS will study time-temperature effects, including calibration. failure mechanisms. and longterm effects. 


\subsection{VELOCITY-OF-SOUND MEASUREMENTS IN SELF-HEATED WIRE}

\section{R. M. Carrol! R. L. Shepard}

A method was developed to measure the veiocity of sound in W-Re alloy wires while the wires are resistance heated in a controlled atmosphere. The velocity of sound is measured in a test segment of wire by butt-welding the segment to wires of different diameters. Sound pulses are reflected from the welded joints, and, by measuring the time interval between the reflections, the speed of sound within the test segment can be determined. The purpose is to develop a sensor which will measure very high temferatures, vtilizing the variation of the velocity of sound with temperature.

Preliminary data obtained from the system were promising. However, the sensor temperature measured with an optical pyrometer involved uncertain emissivity corrections which prevented the most accurate temiperature messurement. An examination of the problem indicates that, with an altered heating methoc (so as to approximate black body conditions) and a better pyrometer, development of the sonic sensor is feasible.

\subsection{THIERMOCOUNE TESTING FTXTURES}

\section{G. W. Allin T. F. Sliski H. J. Stripling Jr.}

Several fixtures were devised for remote handing of irradiated thermocouples in a hot-cell. These thermocouples were being studied to determine the degree of quality control to be specified for procuring thermocouples procured for application in high radiation levels.

\subsection{THERUOCOUIE SURVEILANCE OF HRB-4 EXTERIMENT}
R. L. Shepard
J. W. Cunningham
D. N. Fry
R. F. Hyland

When thermocouples are hrated to temperatures found in the interior of reactor fuel elements, their emf output often drifts, which seriously reduces their reliability for sccurate measurement of such temperatures. One way to detect the drift and possibis to deduce the true temperature of the thernocouple is to monitor the loop resistance of the thermocouple $\&$ a function of time and temperature. For that purpose, the loop resistance of a center fuel thermocouple (W-3Re vs W-25Re) in the inR-3 experiment in the High Flux Isotcpe Reactor (HFIR) was monitcred. The loop resistance was consi. ured both with the calculated center temperature and with the apparent temperature (indicated by the emf of the thermocouple).

A preliminary analysis indicates that after $4500 \mathrm{hr}$ the apparent temperature of the center thermocouple was $300^{\circ} \mathrm{C}$ below the calculated temperature of $1100^{\circ} \mathrm{C}$. During the same time, the total loop resistance increased 12\%. If one acoumes that the resistance changed in only the hot portion of the loop, this represents an increase of $300 \%$ in the resistance of the wire near the thermocouple junction.

In addition to measurements of drift, the transient temperature response of the thermocouples was recorded during the reactor screms at the end of each reactor cycle. From this information, the time constants associated with the temperature response of the HRB-3 experiment were determined, which were important in the reactor fuel study. 


\title{
7.44 TESTS OF THERMOCOUPLES FOR THE HRB-4 EXPERIMENT
}

\author{
R.M.Carroll R. L. Shepand
}

As support for the Reactor Division Higt Temperature Gas Reactor (HTGR I fuet development I: : wram. 25 thermocouples were tested for possible use in the High Flux Isotupe Reactor (HFIR) HRB-4 experiment. All were $0.159-\mathrm{cm}-$ diam, stainlesc steel sheathed. MgO insulated. insulated-junction tiermoccuples. One was W-3Re vs W-25Re: all others were Chrorrel 's Alumel.

The tests incluoied calibration, time response by bej standard and curren:-oulse methods, thermil cycling. thermoeleciric homogeneit $;$, loop and insulation resistance, and time domain measurem nts. After these tests, some of the thermocouples were given a vapor-deposited protective coating of tungsten. The

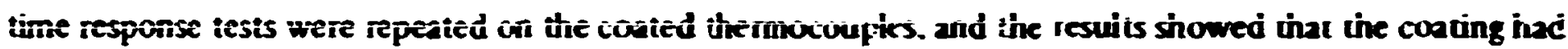
no significant efiect on the time response. The tests permitted the best-choice themocouples to be setected for inclusion in the HRB-4 experiment.

\subsection{THERMOELECTRK. RESSTANCE. AND ULTRASONIC CENTERLINE THERMOMETRY FOR A (UPa) $\mathrm{O}_{2}$ FUEL RN'}

\author{
R. L. Shepard \\ $\begin{array}{lll}\text { R. B. Fitts } & \text { H. E. Robertson } & \text { R. F. Hyland }\end{array}$
}

A W-3Re vs W-25Re thermocoupte and a Re ultrasonic thermoneter". insulated with a threethole hafnia insulator, were emplaced in a wrought W-25Re centerline well in $=6$-in-tong, 0.25-in.-OD stainiess-steel-clad, 85\% $\mathrm{CO}_{2}-15 \% \mathrm{PuO}_{2}$ LMFBR-type fuel pin. A four-wire connection to the thermocouple and to the ultrasonic driver coil was made to obtain accurate loop resistance measurements. The main objectives of the test (ORTC-4) were to measure the decalibration of the centerline thermocouple using the ultrasonic thermometer as a comparison, to relate thermocouple emf changes to thermocouple loop resistance charges. and from postirradiation cxamination, to infer the mecinanisn of decalibration.

The instrumented fuel pin was irradiated in the Oak Ridze Research Reactor (ORR) for $330 \mathrm{hr}$. The indicated temperature of the fuel near the start of the test wa; as bigh as $2300^{\circ} \mathrm{C}$ : it then decreased to $1830^{\circ} \mathrm{C}$ at the end. The ultrasonic thermometer became disconnected early in the test due to a connector failure, but survived the test and was operated during postirradiation examinasion of the cartridge. The thermocouple loop resistanze proved to be a sensitive indicator of the centerline temperature, responding to 19. changes in reactor power and to slight changes in the position of the test cartridge in the core. Data taken periodically throughout the test, rith a constant cladding temperature. showed that the thermocouple loop resistance remained nearly constant while the themocouple emf decreased more than $10 \%$.

The fuel pin was operated at a power production of $18 \mathrm{~kW}$ :It with a clad ID temperature of $700^{\circ} \mathrm{C}$ in a thermal neutron flux of $7.5 \times 10^{13}$ neutrons $\mathrm{cm}^{-2} \mathrm{sec}^{-1}$ and an estimated fuel centerline :emperatuie of $2300^{\circ} \mathrm{C}$. The thermocouple output decreased about $150^{\circ} \mathrm{C}$ per $100 \mathrm{hr}$ for $330 \mathrm{hr}$. This decrease was compared with changes expected due to restructuring of the fucl. about $140^{\circ} \mathrm{C}$. and with results from similar tests recently conducted. Asamoto et al..$^{5}$ observed a decrease of $60^{\circ} \mathrm{C} / 100 \mathrm{hr}$ during irradiation of a W-SRe vs W-2SRe thermocouple in (U-Pu) $\mathrm{O}_{2}$ fuel at $2100^{\circ} \mathrm{C}$ in the General Electric Test Reactor (GETR). Heckelman and Kozar ${ }^{6}$ observed a decrease of about $40^{\circ} \mathrm{C}$ rer $100 \mathrm{hi}$ during nonfueled irradiation of W-3Re vs W-25Re thermocouples at $1800^{\circ} \mathrm{C}$ in the NASA Plum Brosk Reactor. 
Pustirradiation analysis of the fuel pin and thermocouple included neutron radingraphic, metailographic, and electron microprobe techniques to detect changes in the structure or dimensions of the componints and in the diameter or alloy composition of the thermocouple wires and to identify metallic deposits in the fuel and on thermocouple insulators. Examination of the fuel pin showed: (a) restructuring of the fuel, indicating a maximum fuel temperature of about $2300^{\circ} \mathrm{C} ;$ (b) intergranular penetracion of $30 \mu \mathrm{m}$ of the inner surface of the cladding, consistent with a calculated $700^{\circ} \mathrm{C}$ fuel-clad interface temperature:(c) significant distortion of the centerline well where it had not been supported internally 'jy the thermocouple insulator; (d) no apparent change in the thermocouple wire Jiameter that might affeci the loop resistance: (e) no significant change in the Re content of the W-3Re wire; and ( $f$ ) that metallic deposits on the surface of the insulator holes and in the fuel are tungsten. This analysis is consistent with a tungsten-oxygen cycle transport mechanism proposed by Kuhlman and Baxter ${ }^{7}$ to explain W-Re thermocouple failure in out-of-pile tests at $2300^{\circ} \mathrm{C}$ and with observations by Fitts et al. ${ }^{8}$ on W-Re the:mocouples irradiated in (U-Pu) $\mathrm{O}_{2}$ fuel at $2000^{\circ} \mathrm{C}$. 1972.

1. Paper submitted for presentation at 1972 International Meeting, Amer. Nucl. Soc., Washington, D.C., Nov. 12-17,

2. Metals and Ceramics Division.

3. Reactor Chemistry Division.

4. L. C. Lyunworth, E. P. Papadakis, D. R. Patch, K. A. Fowler, and R. L. Shepard, "Nuciear Reactor Applications of "Jew Ultrasol. c Transducers," IEEE Trans. NucL. Sci NS-18(1), 351-67. (February 1971).

5. R. R. Asamoto, P. E. Bohaboy, D. W. Sandusky, and A. E. Conti, "Center Temperature Measurements of Mixed Oxide Fuel - Zero to 3000 MWd/Te," General Electric Co., GEAP-1 3603 (November 1970).

6. J. D. Heckelman and R. P. Kozar, Measured Drift of Irradiated and Unirradiated W3Re/W25Re Thermocouples at a Nominal 2000 K. 1.ewis Resi arch Center, NASA TM X-67818 (June 1971).

7. W. C. Kuhlman an: W. G. Baxter, “ 1000 Hour $-2300^{\circ} \mathrm{C}$ Thermocouple Siability Tests," General Electric Co., GEMP-738 (October 1969).

8. R. B. Fitts, J. L. Miller, Jr., and E. L Long, Jr., "Observations on Tungsten-Rhen «...n Thermocouples Used In-Reactor in (U,Pu) $\mathrm{O}_{2}$ Fuel Pins," Oak Ridge National Laboratory, Paper T-21, Fifth Temperature Symposium, Washington, D.C., June 21-24, 1971. 


\title{
7.46 A THREE-WIRE INSLLATOR-SHUNTING MODEL FOR HIGH-TEMPERATURE THERMOCOUPLE ERRORS'
}

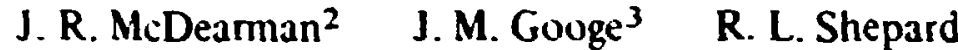

An equivalent sircuit and computer solution were formulated for describing the output of a metal-sheathed bifilar thermoc.uple degraded by insulator shunting at high temperatures. This steady-state equivalent circuit model can be used for prediction of errors in thermocouple calibrations, for examining the effects of changes in thermo:ouple configuration or materials properties, and for examining methods for interrogation or surveillance of the shunting thermocouple:;.

1. Abstract of published faper: IEEE Trans. Indust. El:ctrunics and Contr. Instr. IECl-I8(4), 137 (November 1971).

2. The University of Tennessee. Knoxville.

3. Cônsuitiant from the Üriversity o* Tennessee, Knoxville, Dept. of Electrical Engr.

\section{QUALITY ASSURANCE \\ 7.47 QUALITY ASSURANCE PLAN FOR THE LARGE-SCALE PROCUREMENT OF TEMPERATURE SENSORS ${ }^{1}$}

\section{B. Herskovitz}

A quality assurance program plan was prepared for large-scale procurement of thermocouple bulk material and assemblies. This plan meets the requirenients of AEC-RDT Standards C $7-6$ and F 2-4T and describes the functions and responsibilities of each participant, i.e., the seller, the user, and ORNL personnel in specifying, procuring, storing, assembling, testing, and shipping bulk materials, assemblies, and samples. This plan assures users that they will obtain thermocouples that meet the requirements specified by them.

1. Abstract of published report: ORNL-TM-3740 (March 1, 1972).

\subsection{CODES AND STANDARDS FOR INSTRUMENTATION}

\section{S. Lisser J. A. Russell}

The standards program fo: the Division of Reactor Levelopment and Technology (RDT) of the U.S. Atomic Energy Commission was continued. The purpose of this program is to generate criteria, define terms, and propose general and detailed specifications, procedures, and other standards documents suitable for application to the design, construction, and maintenance of RDT nuclear reactors.

This Division supplied reviews and other advisory services sought for the RDT instrumentation codes and standards and completed work on eight standards, which were approved for tentative use. Another three standards were started.

RDT initiated a move to transform some of its standards into national "'nnsensus" doculrents, for incorporation in the American National Standards Institute (ANSI) catalog. The instrumentation series of RDT standards is the first chosen for adaptation to ANSI requirements.

Work with national terhnical societies was continued through chaimanship of the ISA Control Centers committee (SP 60), and membership on an ASTM Task group in E.20.

Table 1 shows the status of RDT standards. 
Table 1. Status of RDT Standards for Process Instrumer.tation

\begin{tabular}{|c|c|c|}
\hline Number & Title & Status ${ }^{Q}$ \\
\hline C2-1T & Dete: mination of Insulation Compaction in Ceramic Insulated Conductors & A. \\
\hline C2-3T & Time Response Test for Sheathed. Minerai Insulated Thermocouple Assembly & $\mathbf{A}$ \\
\hline C4-1T & Orifice Plate for Orifice Flange Union & $\mathbf{A}$ \\
\hline C4-3 & Orifice Flange Union Weld Neck, Stainless Steel, for 300 Pound Service & $\mathbf{R}$ \\
\hline C6-2 & Differential Pressure Transmitter, Pneumatic Output Sigral & $\mathbf{w}$ \\
\hline C7-1T & $\begin{array}{l}\text { Thermocoupte Material, Iron and Constantan, Solid Conductor (Bare, Fiberglass Insuiated, and } \\
\text { Sheathed over Fiberglass Insulation) }\end{array}$ & $\mathbf{A}$ \\
\hline C7-2T & Thermocouple Material, Iron-Constantan, Magnesium- $0 x^{-}{ }^{b}$ Insulated, Sheather & $\mathbf{A}$ \\
\hline C7-3T & $\begin{array}{l}\text { Thermocouple Materiai, Coppei and Constantan, Solid Conductor (Bare, Fiberglass Insulated, } \\
\text { and Sheathed over Fiberglass Insulation) }\end{array}$ & $\mathbf{A}$ \\
\hline C. 7 - $T$ & Thermocoupie Material, Copper Constantan, Magnesium-Oxide ${ }^{b}$ Insulated, Sheathed & $\mathbf{A}$ \\
\hline C7.5 & $\begin{array}{l}\text { Thermocouple Material, Chromel-P and Alumel, Solid }{ }^{c} \text { Conductor (Bare Fiberglass Insulated, } \\
\text { and Shez:hed over Fiberglass Insulation) }\end{array}$ & $\mathbf{R}$ \\
\hline C7-6T & $\begin{array}{l}\text { Thermocouple Material and Thermocouple Assembly, Chromel-P vs Alumel, Stainless Steel } \\
\text { Sheathed, Magnesium Oxide Insulated (supersedes C 7-6T, 7/70) }\end{array}$ & $\mathbf{A}$ \\
\hline C7.7 & $\begin{array}{l}\text { Thermocouple Materials, Platinum and Platinum-10\% Rhodium Wires, Noninsulated Reference } \\
\text { and Standurd Grades }\end{array}$ & $\mathbf{A}$ \\
\hline C7-15T & Thermocouple Connectors and Thermocouple Connector Panels & $\mathbf{A}$ \\
\hline C7-16T & Thermocouple Assemblies, Magnesium-Oxide Insulated, Stainless Steel Sheathed & $\mathbf{R}$ \\
\hline C7-17 & Phatinum Resistance Ther moineter & $\mathbf{R}$ \\
\hline C9-1T & Single-Point Strip-Chant Recording Potentiometer & $\mathbf{A}$ \\
\hline C9-2T & Multipoint Strip-Chart Recording Potentiometer & $\mathbf{A}$ \\
\hline C11-2T & Pyrometer, High Sensitivity, Indicating and Controlling & $\mathbf{A}$ \\
\hline C13-1 & General Purpose, Stored Program, Digital Computer ${ }^{c}$ & $\mathbf{W}$ \\
\hline C15-3T & Current Pukse Preamplifiers for Use with Fission Counters & $\mathbf{A}$ \\
\hline CI6-1T & Supplementary Criteria and Requirements for RDT Reactor ${ }^{b}$ Plant & $\mathbf{A}$ \\
\hline F3-11T & Mass Spectrometer Helium Leak Detection for Instruments and Small Components & $\mathbf{A}$ \\
\hline M3-20T & Polyethylene Instrument Tubing & $\mathbf{A}$ \\
\hline
\end{tabular}

${ }^{a}$ Approved for issue as a tentative standard; $R$, iseued for revisw; and $W$; in work.

being amanded.

CRewritten.

\subsection{INSTRUMENTATIÚN QUALTY ASSURANCE}

\section{W. P. Kinser D. J. Knowles L. F. Lieber}

In conforming to U.S. Atomic Energy Commission and ORNL practice, this Division has embarked on a program of formal quality assurance (QA) measures, supplying ORNL with a QA coordinator ard an assistant QA coordinator for instrumentation and controls and writing QA procedures applicable within this Division.

Quality audits were conducted both by Division personnel and by Laboratory audit teams; and where audits showed the need for correctiv s measure: they were instituted. The QA program was explained to the Division staff, including foremen, in a series of meeting, and instrument numbering schemes were adopted for $Q A$ identification of irdividual instruments installed at ORNL. 


\subsection{INSTRUMENTATION AND CONTROLS DIVISION DRAFTING AND DESIGN STANDARDS COMMITTEE}
K. W. West
H. E. Cochran
J.W. Cunningham
P. G. Herndon
C. F. Holloway
J. A. Russell, Jr.
H. J. Stripling, J $\mathrm{r}$.
O. M. Thomas ${ }^{1}$

This committee of eight engineers, representing each design and engineering section of the Division, was established to review the design activities of the Division, prepare recommendations for a uniform method of documenting the Division design standards, and to make the documentation more useful for maintenance and modification. Emphasis of quality assurance in design and operation of systems and facilities at ORNL requires greater consistency in the design of instruments and controls. Therefore, the committee evaluated drafting symbols, methods of documentaticin of revisions, definiticns of terms, and drawing nomenclature. and has selected those judged best for Division standards. Several parts of a manual of standards were prepared and are ready for publication.

Each committee member has spent $\sim 4$ days/month on this assignment. The committee is meeting its responsibilities as designated in QA-IC-6, "Instrumentation and Controls Drafting Prosedures."

1. General Engineerine Division. 


\title{
8. Reactor Instrumentation and Controls
}

\author{
ANALYSIS

\subsection{HYBRID COSPPIJTER SIMULATION OF THE MSBR}

\author{
$\begin{array}{lll}\text { O. W. Burke } & \text { J. L. Anderson } & \text { S. J. Ditto }\end{array}$
}

A hybrid computer simulation model of the reference !00'MMW(e) MSBR was developed. The model simulates the nucleat reactor, the system heat transfer, and the steam generation system through the turbine throttle. The steam enerator was simulated on the hybrid computer with a discrete-time, continuous-space model. The remainder of the system was simulated as an all-analog, continuous-time, lumped-parameter model. The two models were then :ittegrated into a single computational system.

A year ago, the sinulation was nor quite operable, but since then the difficulties were resontred and simulation was accomplished using a time scale 20 times real system time.

The simulation model was used for a variety of steady-state and transient studies. Burke has described these studics and their results, a well as jevelopment of the model.'

This steam generator model is being adapted for simulation of the Gas Cooled Fast Breecier Reactor proposed by Gulf General A: sinir.

1. O. W. Burke, Hybrid Computer Simulation of ihe MSBR, ORNL-TM-3767 (May 5. 1972).

\subsection{AN INTERPRETATION OF 2.0 - 2.57-MEV NEUTRON PULSE PROPAGATION IN IRON'}

\author{
$\begin{array}{lll}\text { R. B. Perez } & \text { R.S. Bonth } & \text { A. R. Buhl } \\ \end{array}$ \\ J. C. Robin:on ${ }^{3} \quad$ E. Carroll ${ }^{4}$
}

Neutron pulse propagation in iron was predicted and compared with recently obtained experimental data because of the importance of iron in shielding calculations and the recent availability at ORNL of reevaluated iron cross sections and a transport kinetics code (TASK). The preliminary results from this study for neutron energies be:ween 2.0 and $2.5 \mathrm{MeV}$ indicate that the theory underpredicts the amplitude of neutron waves and overpredicts their phase shift as a function of penetration depth in the iron. Howevel, the experiments! results can be explained by postulating that there is a stronger window effect than predicted fo: minimums in the total cross section of iron. The changes in the cross section of iron needed to produce a stronger window effect to match the experimental results may be within the uncertainiy of the measured cross sections.

1. Summary of paper presented at 1972 Annual Meeting of the American Nuclear Society, June 18-22, 1972, Las Vegas.

2. Neutron Physics Division.

3. Consultant from the Nuckar Engineering Dept., the University of Tennessec. Knoxvilke.

4. Nuckar Engineering Sciences Dept., University of Florida, Gainesville. 


\subsection{BLOWTHROUGH EXTERIMENTS ON THE OSW WRIGHTSVILLE BEACH 3.STAGE FLASH EVAPORA TOR, AUGUST 1970'}
J. G. Delene ${ }^{2}$
S. J. Ball
N. E. Clapp. Jr. ${ }^{3}$

A series of tests was run on a three-stage experimental flash evaporator at the Office of Saline Water Test Station at Wrightsvilk Beach. North Carolina, in August 1970. This report is concemed with portions of the tests in which the evaporator was in the blowthrougt: mode of operation.

Some nbscirvations are made on the operations chasacteristics in the blowthrough mode and the transitions into and out of this mode. Explanations for some of the plant blowthrough behavior are presented.

1. Abstract of report ORNL-RM-\$420 (to be published).

2. Reactor Division.

\section{DEVELOPMENT}

\section{A. Fast Reactor Kinetics and Subcriticality Measurement}

\subsection{ONLLNE SUBCRITCAUTY MEASUREMENTS N SEFOR 1.2}
A. R. Buhl
N. J. Ackermann, Jr.
R. C. Kryter
J. C. Robinson ${ }^{3}$

A protoiypical subcriticality monitoring system (SMS) was developed and successfully demonstrated on-line in an operating, sodium-cooled fast reactor. Messurement of the subcriticality of an LMFBR is desirable fiom both economic and safety considerations. However, a practical on-line system had not been denonstrated previously under realistic operational conditions. The ultimate goal of this ORNL program is to employ an SMS in the FFTF and future demonstration plants.

We performed a realistic engineering test and evaluation of an SMS prototype in the SEFOR. The SMS comprises breah frequency noise analysis (BFNA), inverse kinetics (IK), and modified source multiplication (MSM) techniques. The SEFOR was selected for this evaluation owing to its hostik LMFBR-like environment: specifically, an intense gamma field of about $10^{\circ} \mathrm{R} / \mathrm{hr}$, a temperature oi about $350^{\circ} \mathrm{F}$, a liquid sodium coolant, and a high electromagnetic noise background.

In addition to the test and evaluation, two further objectives were to obtain a precise and accurate measurement of the prompt die-away time constant $(\Lambda / \beta)$, and obtain additional data on the intercomparison of reactivity values determined from iK and BFNA.

Measurements using two ${ }^{235} \mathrm{U}$ fission counters were made in a soît spectrum with BeO (Core 1) and in two configurations of a hard spectrum with BeO removed (Core 2). BFNA and MSM measurements were made for several reacior states from critical to full shutdown for each of the three core configurations. IK measurements were made for several of these states by dropping reflector elements from a more reactive to a final state of interest and processing the time-dependent data from the fission counter.

The MSM differs from the standard neutron source multiplication technique in that changes in detection efficiency $W$ and effective source $S_{0}$ are incorporated linearly into the coum. rate (CR) interpretational algorithm:

$$
C R=W S_{0} j(\nu \bar{\beta}|S|)=K /|S| \text {. }
$$

Further, the MSM is calibrated near critical by determining $|S|$ by either the IK or BFNA technique and simultaneously measuring the CR to determine the calibration factor $K$. Changes in $W$ are calculable foi different reactor configurations, using standard reactor physics codes. 


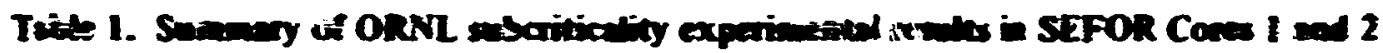

\begin{tabular}{|c|c|c|c|c|c|}
\hline \multirow{3}{*}{ kezitor configurisor: } & \multirow{3}{*}{$\begin{array}{l}\text { Yeisuned } \\
\text { Iif } \\
\text { inseci }\end{array}$} & \multicolumn{4}{|c|}{ Rexitivity i-5) } \\
\hline & & \multicolumn{2}{|c|}{ Intercosipuerison } & \multicolumn{2}{|c|}{ Full shutdown } \\
\hline & & BFNA & $1 K^{b}$ & MSt & $\mathrm{MSM}_{\mathrm{IK}}$ \\
\hline $\begin{array}{l}\text { Core: } \\
\text { (soft spectrum) }\end{array}$ & $130.5 \pm 2.5$ & $\begin{array}{l}1.01=0.03 \\
2.35 \div 0.10\end{array}$ & $\begin{array}{l}1.04=0.01 \\
2.28 \pm 0.02\end{array}$ & $5.19 \div 0.16$ & $5.24 \pm 0.05$ \\
\hline $\begin{array}{l}\text { Core } 2 \\
\text { Complesty refected } \\
\text { (hand spectrum) }\end{array}$ & $1+2.6=2.8$ & $\begin{array}{l}1.13 \div 6.06 \\
2.82=0.17\end{array}$ & $\begin{array}{l}1.11=0.02 \\
2.59=0.04\end{array}$ & $8.93=0.47$ & $3.77 \div 0.16$ \\
\hline $\begin{array}{l}\text { Core } 2 \\
\text { Parrialy refected }\end{array}$ & $131.0=4.3$ & $1.56=0.05$ & $1.4 T^{2}$ & $7.35 \div 0.24$ & $6.94^{2}$ \\
\hline
\end{tabular}

EBrealfiequency noise analysix

binverse kinetics

Cyodified sounce raltiplication cibbrated using BFNA at - IS nomi_al.

dModified source multiptication calibrated using IK at - IS nominal.

'Precision estimate not avabble.

Values of $\Lambda / \beta$, intercomparisons of reactivities from BFNA and IK, and the MSM fullshutdown reactivity as listed in Table 1 typify data taken at some 20 different reactor configur zíions.

Our conctusions from this evaluation are that:

1. The subcriticality manitoring system prototype performed successfully in an LMFER environment.

2. Precise vaives of N/B were obtained for SEFOR Core 1 and two configurations of Core 2.

3. No systematic differences were observed for our binited intercornparison of reactivity values inferred from inverse kinetics and breakfrequency noixe analysis.

1. Abstrest of paper pablished in Thens Amer. Nuct Soc 1S(1), 423 (June 1972).

2. It is a pleasure to ackncwledwe the inportant confributions made by J. B. Bullock, D. N. Fry, and C. B. Stokes of ORNL, the SEFOR operation stef, and vie Breeder Reactor Developanent Division of Ceneral Electric.

3. Consultant inom the Nuclear Engineering Department, Univenity of Tenneswee, Knoxvitle.

\title{
8.5 THE DETECTION EFFICIENCY DEPENDENCE OF SURCRITCALITY MEASUREMENTS BY THE POLARITY SPECTRAL COHERENCE METHOD'
}

\author{
N. J. Ackermann, Jr. A. R. Buhl
}

The polarity spectral coherence method (PSCM) of Seifritz has been proposed for measuring the subcritical reactivity of a nuclear reactor. However, the to the nature of the PSCM measurement techrique, a systematic error in the subcritical reactivity measurement may orcur owing to unexpected changes in the neutron detection ifficiency.

In this paper, this error is ascessed through the development of the appropriate equations, and a hypothetical me-asurement in a typical liquid-metal fast breeder reactor is numerically evaluated.

1. Abstrect of published paper: Nucl. Technonl. 12,326-23 (November 1971).

\subsection{LOW-LEVEL NEUTRON FLUX MONITORING SYSTEM FOR LMFBR's'}
N. J. Ackermann, Jr.
D. P. Roux
W. T. Clay
G. C. Guerrant

A low-kvel neutron flux monitoring (LLFM) system for LMFBR's, required for reactor operations in the source range, has been developed and tested. ${ }^{2}$ Development of this system is part of the experimental 
effor of the SRNL development program on subcriticality nessurentent systems for LMFBK's. Since in-vessel neutron sitectors are required for 27 LLPM system. they must funditon in an extremely hostile environment: of liquid sodiuts: high temperature. ganne radiation, and electromagnetic nasse levels. The design gooks af the ORNL system were es?ahlished to meet this expected envirmmental conditions in a representative reactor. the FFTF: in particuia. a temperature of $350^{\circ} \mathrm{F}$ and a gamma field of $10^{\circ} \mathrm{R} / \mathrm{hr}$. The ORNL LLFM system was lested undar simulated IMFFis enditions: these tsess were followed by the

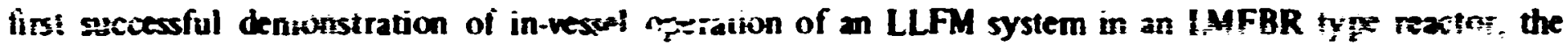
SEFOR. The sucuessful opertion of the ORNL LIFI system in the SEFOR demonstrated the functional capability of the system in an environment similar to that expected in the FFTF.

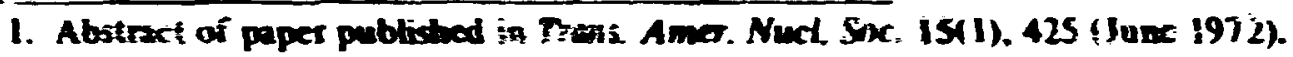

2. RDT Stantard CIS-3T. "Cuneat Puive Preamplifiers for Frewon Counters." Division of Reactor Develepment and Tecienology. US. Atomi Eny Commission ! 1971 !

\title{
8.7 DEVELOMENT AND DESKG PROGRAM FUL FFTF SUDCRITCALTY AND STARTUP PHYSICS MEASUREMENT SYSTEY
}

\author{
N. J. Ackermann, Jr.
}

As an evolution of the base technology development progran in fast reactor kinetics and subcriticality measurements at ORNL, a deveiopaisnt and design progrem for systems to be used in the Fast Flux Test Facihty (FFTF) for subcriticality measurement and for special startup nuclear physics testing has been set up at ORNL in cooperation with Hanford Engineering Development Laboratory (HEDL), the FFTF operator. and with Westinghouse Advanced Reactor Division (WARD), the prinsipal reactor designer. The progem is designed to provide operational systems for use in the FFTF at its scheduled startup of July 1974.

ORNL is responsible for any needed development of methods and instrumentation (sensors, signal conditıoning eiectronics, and data processing equipinent), fon all supportive nuclear phy sics calculations, for the principal design of the measurement systems, for system proof-testing, and for assistance to WARD and to HEDL in interfacing of the systems inio the overall FFTF design and in initial system operations.

Efforts completed to date are:

1. the formulation of an overall program plan,

2. an evaluation of the FFTF design to determine system requirements,

3. a critical review of the FFTF flux monitoring system tc netermine its adequacy as system sensors,

4. initiation of a critical experiment design for general measurement method development and for specific FFTF system proof testing.

5. initiation of preliminary system designs for the FFTF systems.

\subsection{DEDICATED CRITICALFACILITY SUBCRITICALITY EXPERIMENT: EXPERIMENT PLANNING AND INSTRUMENTATION SYSTEM DEVELOPMENT}
N. J. Ackermann, Jr.
A. R. Buhl'
J. T. De Lorenzo
M.V. Mathis
J. C. Robinson ${ }^{2}$
D. P. Roux

A dedicated critical-facility experiment will be performed in the ZPR-9 at Argonne National Laboratory in January 1973 as part of the RMAAS (Reactivity Measurement and Anomaly System) and of the special startup nuckear physics testing development and design program being carried out by ORNL in surport of the FFTF project. The purposes of this experiment are threefold: 
1. a peral subcritical. Iast-reactor kinetics study to investignte previously observed discreparicies in measurements of subcriticality and $\mathrm{h}$.

2. a proof-lesting of ra-hods to be used in RMAlis.

3. a proof-tescing of methuds to be used in FFTF specidl startup risclear physics testing.

The detzled planning of this experiment was started. A fourdimensional. experiment will be perfomed, with the four dimensions being measurement method, neutron detector type, deitstor pasition, and degree of reactor subcriticality. Ako, simuiated FFTF measurements will be performed in proof-testing the FITF systems. An FFTF core mockup londing in the ZPR-9 will be used for the experiment.

Four different neutron detection systems are currently under development and design for the

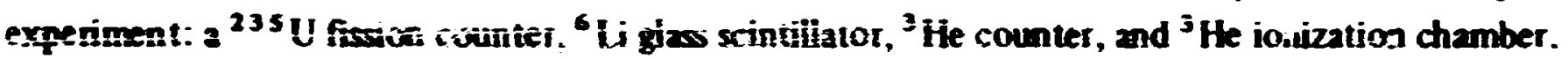

1. Neutron Prysics Dirsion.

2. Consulaset from Nucter Fagineering Depertment, University of Teaneswee, Knosx ville.

\subsection{AUTOMATED INVERSE KINETICS RODDROP DATA ANALYSES SYSTEM}

\section{J. E. Mott $\quad$ H. K. Churchich' J.C. Robinson'}

A system using a PD-11 minicomputer and a tape recorder is being developed to record and analyze data (for the determination of subcrituclity) from inverse kinetics rod-drop (iKRD) experimenis. The system will permit the simultaneous digital sumpling and recordine of the output signals from a maximum of seven neutron detectors. Of the seven detectors, the system will accommodate a maximum of frve detectors operating in the putse mode or five in the ionization mode at any one time.

In addition to data loging, the system will analyze the data in real time. A single preselector channel will be andyzed using the source iteration method, ${ }^{2}$ and a predetermined four to seven channels (depending on the rate at whict. data are being sampled) will be analyzed using the three-point method. ${ }^{3}$

As soon $a$ an experiment is completed, the results of the real-time analysis will be printed out. Then graphical displays, such as the determined reactivity us time, will be shown which the operator can use for diagnostic purposes.

In addition to data analysis in real time, the system will be used to analyze reco.ded data by the source iteration method in off-line operation.

1. Nucles Engineering Depertment, the University of Tennessec, Knoxvilte.

2. C. E. Cohn, "Experience with Subcriticality Determination by Rod Drop in the FTR-3 Critical Experiments," Thans Amer. Nuct. Soc. 14, 29 (1971).

3. S. G. Carpent ir and R. W. Goin, "Rid-Drop Measurements of Subcriticality," Reactor Thysics Division Anmu. Rep. July 1, 1959, to June 30, 1970 , AN'-7710.

\subsection{COUNTING-LOSS EFFECT ON INVERSE KINETIC, ROD-DROP MEASUREMENT OF SUBCRITICALITY}

\section{J. C. Robinson' N. J. Ackermann, Ir. J. W. Allen ${ }^{2}$}

The effiect of counting loss on subcriticality measurements by the inverse kinetics, rod-drop (IKRD) technique was determined and analyzed theore irally, and the resultant conclusions were verified using IKRD data that had been obtained experimentaily duriug operation of the Southwest Experimental Fast Oxide Reactor (SEFOK). ${ }^{3}$ The count.ng loss effect will be important in IKRD measurements of subcriticality in power reactors, because in such reactors fission counters with their attendant limited 
dynamic range must be used as the neutron sensors so that the neutron signal can be separated by pulse-height discrimination techniques from the signal induced inv the intense gamma field $110^{6} \mathrm{R} / \mathrm{hr}$. typically).

In principle. the subcriticality before the rod drop ( $\rho$-initial) and the subcriticality after the drop ( $\rho$-final) an be determined from an IKRD experiment. This work demonstrated that counting loss does not affect the inferred $\rho$-initial but it does affect the inferred $\rho$-final. Since reactor shutdown procedures can be scheduled such that the measuremerits of $\rho$-ir aid from IKRD experiments are sufficient. we conctuded that the counting loss associaied with pulse muse detectors $\mathrm{can}$ be eliminated by employing proper procedures in IKRD subcriticality mezsurenrents.

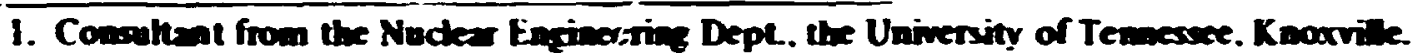

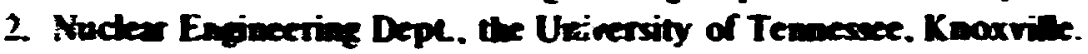

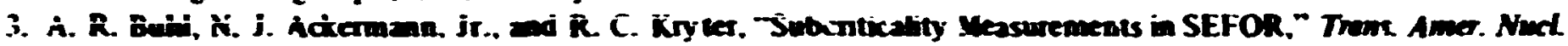
Soc 15(1). 423 (June 1972).

\subsection{AN INTERCOMSARASON OF TECHNQUES FOR INFERRING SUECRTTCALTY IN FAST REACTORS'}

\section{A. R. Buhl J. C. Robinson ${ }^{2} \quad$ N. J. Ackermann. Jr.}

Since recent experiments indicate that systematic differences may exist between the reactivity (S) values inferred frem various subcriticality measurement techniques, ${ }^{3-4}$ the pousibte discrepencies in $S$ values inferred by several measurement techniques were investigated. Such discrepencies have serious implications on the andysis of rexctor physics measurements which depend on accurate estimates of S, as well as on the development of shutdown monitoring systems.

In this study, with a one-dimensional neutronic model of the Fast Test Reactor (FTR), the value of S was calculated which would be inferred by one static and several kinetic techniques for reactor states from critical to $30 \mathrm{~S}$ subcritical. Static and kinetic fluxes were calculated for the one-dimensional, thirteen-region FTR model, using a recenitiy ieveloped transfer and scattering kinetics (TASK) scheme that is based on trensport theory.

To intercompare $S$ values from the various techniques. fluxes were folded with cross sections of the active detection material to produce both static and kinetic detector responses for a low-eniergy-sensitive

${ }^{2.35} \mathrm{U}$ fission counter and a high-energy-sensitive ${ }^{240} \mathrm{Pu}$ fission counter. These responses were then andyzed using the specific algorithms of the various measurement techniques which relate detector response to $S$. Correction factors which account for the spatial location and energy response of detectors on inferred $\mathbf{S}$ values were applied to results from each of the techniques.

From this study the following conclusions have been made:

1. Reactivity estimates from the various techniques intercompare favorably in the kinetic range of 0 to $7 \mathrm{~s}$ when corrected for space and energy effects.

2. Measurements in the reflector tend to systematically overpredict reactivity.

3. Values of reactivi:y inferred from kinetics techniques which measure prompt multiplication or statics techniques are biased by detection efficiency changes.

4. Values of reactivity inferred from kinetic techniques which measure the prompt die-away time constant are biased by modal contamination (usually overestimating $\mathbf{S}$ ).

1. Abstract of paper published in Trans Amer. Nucl. Suc. 15(1), 493 (June 1972).

2. Consultant from the Nuclear Engineering Department. University of Tennessee, Knoxvilk.

3. Robert W. Alürecht and George M. Hess, "A Comparison of Inverse Kinetics and Polarity Spectrum Reactivity Mesirements in FTR," Trens. Amer. Nucl. Soc. 14, 45 (1971). 


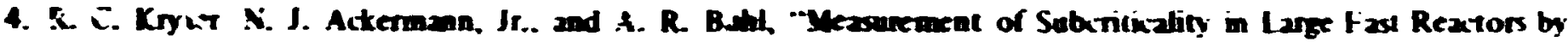

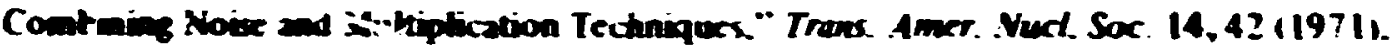

$\therefore$ H. L. Dods. Jr.. J. C. Robinson. and A. R. Buhl. The Formebtion and Application of the Irander-Saltering

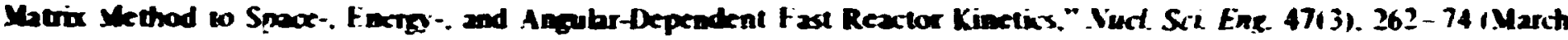
1972).

\subsection{SULCRITKALTTY MEASUREMENTS IN FTR-3: THE HOMOGENEOUS MOCKUP OF THE FAST TEST REACTOR'}

\section{R. C. Kryier N. J. Ackermann. Jr. A. R. Buhl}

A seties of experiments was perfiormed in the ZPR-9 critical assembly at the Argunne National Laboratosy to imvestigate the capability of variours measurement techniques in determining the

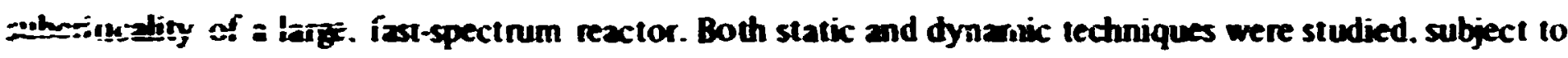

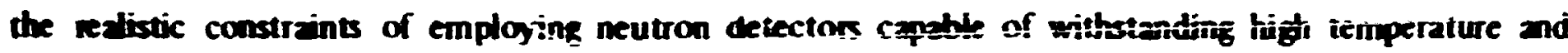
gamma flux and positioned in the reactur's iztial reflector region. The full-range subcriticality measurement method proposed by OPNL (namely. the modified .eutron source multiplication technique, calibrated near delayed critical by the breakfrequency neutron noise analysis technique and refined through numerical calcubtions of possible neutron detection efficiency alterations) proved both accurate and workable.

1. Aberect of poblisted report ORNL-TM-3715 (Febramy 29. 1972).

\subsection{VARIA TON OF THE NEUTRON GEJERATION TMEE WTH SUBCRITKALTY WN THE FAST TEST REACGOR'}

\section{A. R. Buhl J.C. Robinson ${ }^{2}$}

We have calculated the variation of neutron generation time $(\Lambda)$ with subcriticality for : ihe Fast Test Reactor (FiR). This variation introduces a systematic error into reactivity ( $($ ) values deteinined by the use of techniques which measure the prompt die-away time constant. The variation of $A$ with $S$ was determined by calculating 1 for different states from critical to $\sim 30$ S subcritical for the FTR of the Fast Flux Test Facility (FTR-3 bading of the ZPR-9) and by comparing the value at critical witt. the measured value.

The $\Lambda$ values were calculated for each state by three methods: (1) the lambda ( $\lambda$ ) mode method, (2) the omeg ( $\omega)$ mode method, and (3) a direct $\Lambda$ calculation using a new algorithm. In the first two methods, the definitions of $\Lambda$ result from a reduction of the time-dependent transport equation to the point kinetics equations. In the third method, a recently developed transfer and scattering kinetics (TASK) scheme directly computes the prompt die-away time constant and combines the computed response of a lowenergy and a high-energy sensitive detector to compute $\Lambda$. The first two methods were implemented using the transport code ANISN and the third by using TASK.

From results of this study on the FTR, we have drawn the following conclusions:

1. Values of $\Lambda \mathrm{cm}$ be computed adequately using any of the three methods at critical.

2. The $\lambda$-mode method appears to underestimate $\Lambda$ with increasing subcriticality when compared with the two other methods.

3. Sinxe variations in the kinetic range from 0 to $-7 \mathrm{~S}$ are less than $10 \%$, the assumption of constant $\Lambda$ is reaccnable for an operation.al measurement of subcriticality.

4. Based on the TASK calculations, it appears that $\Lambda$ can be measured directly at subcritical states by simultaneous collection of data from a lowenergy sensitive detector (e,g., ${ }^{235} \mathrm{U}$ fission counter) and a highenergy sensitive detector (e.g., ${ }^{238} \mathrm{U}$ fission counter).

1. Abstract of paper to be presented at the American Nuclear Society National Topical Meeting on New Developments in Reactor Physics and Shielding, Kiamesha Lake, New York, and to be published in the meetine proceedingo.

2. Consultant from the Nuctear Engineering Department, the University of Tennescee, Knoxville. 


\subsection{TASK: A GENERALIZED ONE-DIMENSICNAL TRANSPORT AND UIFFUSION KINETICS CODE}
A. R. Buhl
H. L. Mudds. Jr.:
O. W. Hermann:
R. J. Hintun?
R. A. Lillic ${ }^{3}$
J. C. Robinswon

A une-dimensional nultigroup kinetiks cude. TASK. which sul:es either the transport or diffusion form of the Bu!tumann equations and allows an arbitrar number of delaged neutron groups was developed ar.d a user's manual was prepared. TASK an be used to solve static as well as dynamis problems. reciuire: no inner iterations within energy groups. and my be ran either in an outer-iteration mude or in a clused (non-iteration) mode. The time variable in this version of TA SK is removed by: Laplact transtormation.

The user's manual describes the input data requirements. the various options available to the user. and operationai notes. Sampie probiems are inciuded to ad the user in the application of the code.

1. Present address: Srvannah River Latoratory. Aiken. South Carolian.

2. Mathematics Division.

3 The University of Tenneweer. Knoxville.

4. Consitant from the Depantment of Nuclar Engineering. the Liniversity of Tennessec. Linvivilli

S. A. R. Buhl et al, A Ciset is Wenual for T.ASK. OR.NL-TH-38I i (1972).

\subsection{SUBCRITICAUTY MEAGUREMENT IN AN LMFBR'}

\section{J. Ackeniann. Jr.}

Reliabie knowledge of the subcriticality siate of a nuclear reactor at all times during shutdowr. coupled with proper administrative control. should preclude the possibility of that reactor acidentally becoming critical or supercritical. This review of the state of the art of subcriticality measurement in the LMFBR gives particular attention to four measurement techniques: neutron-sosrce multiplication. neutron-noise analysis. inverse kinetics, and pulsed neutrons. It is concluded that the neut:on-source multiplica:ion technique is the only method applicable for measuring the subcriticality in an LMFBR cver the ful: range of shutdown. Present subcriticali iy-measurement development programs are reviewed, and future applications are discussed.

1. Abstract of published article: .Nucl. Safert. 12(6), 583-90 (November-December 1971).

\section{B. Neutron Sensors for Extreme Environments}

\subsection{DEVELOPMENT OF A FISSION COUNTER FOR HIGH TEMPERATURE APPLICATION}

$$
\begin{array}{lll}
\text { W. T. Clay } & \text { D.P. Roux } \quad \text { G. C. Guerrant }
\end{array}
$$

A high temperature fission counter ${ }^{1}$ is being developed for use as a low-level flux monitor in the LMFBR. The ultimate design goal is the fabrication of a counter with a neutron sensitivity of 1.0 count $\sec ^{-1} \mathrm{nv}^{-1}$ when subjected to a gamma flux of $10^{6} \mathrm{R} / \mathrm{hr}$ and a temperature of $1100^{\circ} \mathrm{F}$.

A 2.5 -in.-diam fission counter and integral cable assembly were designed and partially fabricated. Parameters were factored into the design from studies and experiments concerning material selection. gamma pile-up effect minimization (Sect. 8.18). and cable shielding characteristics (Sect 2.23). Essentially. the electrode design is a configuration of three concentric cylinders plated with ${ }^{235} \mathrm{U}$ to a thickness of 2 $\mathrm{mg} / \mathrm{cm}^{2}$. To cbtain a short collection time, the electrode spacing is $0.060 \mathrm{in}$. All internal parts of the counter are either type 304 stainless steel or $99.5 \% \mathrm{Al}_{2} \mathrm{O}_{3}$. Problems associated with the difiorence in the coefficient of linear expansion of these two materials had to be resolved. 
A major effiort has been the fabricatiol. and testing of the metal-clad mineral-insulated coaxial cable and end-seal insulator assemblies. The pulse b:eak.down noise at the uperating voltage and temperature cannut be tulerated it it is larger than the electronic nuise letel. Two pretested cables are to be welded to each counter assembly. Techniques are now being developed for welding miniature, high-purity alumina end-seals to the cuble. The repeatability of a hagh quality weld is an outstanding problem.

Aiter completion of the fission counter, extensive tests will be performed to qualify it for use in the LMFBR.

1. D. P. Roux at al., "Neutron Sensors for Extrime Environments." Instrimentation and Controir Div. Annu. Progr. Rep. Sept. 1. 1971 , ORNL-4734, pp. 14-15.

\subsection{FISSION COUNTER TESTING PROGRAM}
W. T. Clay
D. F. Roux
B. J. Ball'

As part of a high-temperature neutron-sensor development activity (Se i. 8.16) a deicetor test:ing program was started ror evaluation of commercial fission counters. The purpose of this testing is the:

1. possible qualification of dete:tors for use in the LMFBR as low-level neutron flux monitors.

2. comparison of performance with the ORNL design,

3. failure-mode analysis to incorporate the findings into the ORNL design.

Two fission counters (CFUC-02) were purchased from a commercial supplier for this intent. The counters were fabricated with $10 \mathrm{~m}$ of metal-clad mineral-insulated triaxial cable for rated operation at a temperature oi $1100^{\circ} \mathrm{F}$. The neutron sensitivity was stated to be 1.0 count $\sec ^{-1} \mathrm{nv}^{-1}$ with total gamma rejection at $10^{6} \mathrm{R} / \mathrm{hr}$.

The characteristics of the counters were tested extensively at riom temperature. Subsequent tests at 600 and $800^{\circ} \mathrm{F}$ indicated that the sensitivity and voltage saturation were time dependent.

From thece observations we concluded that the internal parts olitgassed at temperature, thus contaminating the detector gas filling. Discussions with the vendor confirmed that the counters were not vacuum baked at their rated temperature prior to filling.

1. Summer technica! student, New York University.

\subsection{FORMULATION OF THE GAMMA PILE-UP EFFECT IN FISSION COUNTERS ${ }^{\prime}$}

\section{P. Roux J. C. Robinson}

The neutron response of fission counters (FC) exposed to verv high gamma fluxes is strongly degraded by pile-up of undesired gamma-ray detections. An equation was derived and experimentally verified to express the amplitude distribution of the gamma pile-up ( $(, P U)$ as a function of the gamma flux $\phi_{y}$ and detector parameters sucn as the electron collection time $\tau$.

A single neutron can, in principle, be separated fr $r$ a single gamma pulse by pulse height discrimination. However, in large gamu.1a fluxes the gamma pulse rate is so high that gamma pulses cannot be detected individually. For example, at $10^{6} \mathrm{R} / \mathrm{hr}, \phi_{\gamma^{\mathrm{r}} \gamma}$ would be about $3 \times 10^{11} \mathrm{pulses} / \mathrm{sec}$, and if the electron ccllection time were $10^{-7} \mathrm{sec}$, an average of $3 \times 10^{4} \mathrm{ganma}$ interactions would occur (pile-up) per unit time $\tau$. In such a gamma field, the output current from tie counter would be continuous, with a mean component and a fluctuatir. 6 component due to the statiscical nature of the detection process. The mean component of the gamma-induced signal could be large enough to pass through the pulse height 
discriminator and. hence. contribute to the observed counts. Because the gamma-induced events are randomly distributed. they obey Poisson's distribution: acicordingly, the stindard deviation of the ar.plitude of the gamma-induced current was derived.

Using the proparties of the nurmal distribution function, a GPU function vs discriminator setting in standard deviaticn units was constructed. Then we verified the shape and amplitude of this analytic GPI distribution with experimentally ohserved GPU distributions.

This work demonstrates that the GPU effects can be understood and predicted by considering the statistical nature of the detection process. In particular. the analytical and experimental GPU distribution vs pulse height setting agree well. and the GPU distribuiion function is proportional to $\phi_{\gamma}^{1 / 2}$ and $\tau^{-1 / 2}$.

1. Sumnary of article published in Trans. Amer. Nucl. Soc. 15(1). (June 1972).

\section{Computer Contro'}

\subsection{COMPUTER SURVEILLANCE OF REACTIVITY DURING STARTUP AT THE HFIR}

$$
\begin{array}{lll}
\text { W. H. Sides. Jr. J. W. Allen' } & \text { J. B. Bullock }
\end{array}
$$

Three sources of reactivity important during startup at the HFIR were added to those previously included in the ontine computer reactivity balance calculation. They were: (1) effects of Xe produced in the Pu target located in the flux trap region, (2) changes in the worth of newly installed control rods, and (3) effects due to power-related temperature increases. Inclusion of these sources enhances the computer sensitivity to the detection of unusual and putentially unsafe conditions during reactor operation, expecially variations in local coolant flowrate.

Pesults from this study indicate that the amount of reactivity added to the system from burnout of target Xe during startup is $\sim \mathbf{4 0}$ cents.

A source of dynamic reactivity is present in the control rod region if any of the five control rods are replaced. If all contro! rods are replaced, the combined increase in rod worth may be as much as $\mathbf{2 . 7 0}$ dollars during the first $48 \mathrm{hr}$ of operation, due to production of 115 -day ${ }^{182} \mathrm{Ta}$ in the tantalum section of the control rods.

Temperature fecibask is a reactivity source during startup. Analog simulation studies have shown that the magnitude of this reactivity is proportional to the instantaneous power level and that the reactivity deficit obse:ved during a startup to full power is $\sim \mathbf{4 0}$ cents.

Results of measurements made at HFIR during startup indicated that, previously, variations in the reactivity balance remained within a band of \pm 12 cents for a powe: incriase from i0 io $100 \mathrm{MW}$. The inclusion of the three additionai sources reduces the band to \pm 4 cents. Analog computer model studies indicate that this improvement in the reac:ivity surveillance will allow desiction of flow blockage in the target region during startup before boiling occurs. Further experimental verification is needed.

1. The University of Tennessee, Knoxville.

\subsection{PROGRAM FOR THE FAST FOURIER TRANSFORM ON THE HYBRID COMPUTER}

\section{W. H. Sides, Jr.}

A digital computer program for calculating the fast Fourier traneform (FFT) was developed for the Division hybrid computer from a version formerly used on a Bunker-Ranw 340. This program enables more rapid and convenient reduction of random noise data. Hybrid computing componerits were used to sample. scale, and store input data directly from on-line or tape-recorded signals. Capability for handiing two input 
channels was included. The hybrid progran simultaneously samples the input signals in blocks and computes the FFT. This allows input signals of long daration to le processed without a requirement for large amounts of input data storage.

\subsection{QUAUTY ASSURANCE TECHNIQUES FOR ON-LINE PROCESS COMPUTER SOTTWARE}

\section{J. B. Bullock}

Operating experience with an on-line process control computer at the High Flux Isotop: Reactor (HFIR) has indicated that quality assurance of the software is a major consideration in planning and operating such systems. The following practices proved most helpful in maintaining the integrity of the HFIR software:

1. Conputer listings of all system programs are maintained in a clearly indexed file or notebook. This file incluais a list of the previous version of any revised or corrected program.

2. A copy of all system program source images (cards, tape, etc.) is maintained, clearly labeled by name and revision date or number.

3. A logic block diagram of all complex programs showing their relationship to other programs in the system is mintained. Both the serial logic and the parallel logic forms described below are used for the more complex programs.

4. Appropriate designer comments are required in the comment fields of each program to clearly document the intent of the adjacent computer instruction groups.

5. A software change procedure was established and rigidly enforced.

Many of the techniques specified above are reasonabiy obvious, which, no doubt, many computer operators have recognized and implemented. However, the construction of both serial logic and pirallel logic block diagrams is probably unique with ORNL.

A serial logic diagram is a corventional logic diagram usually drawn by computer programmers showing yes-no decision blocks and the functions being performed as the logic flows in a manne: roughly synchronous with the program instructions. The term "parallel lopje" is applied to a logic diagramming method developed for analog control system design. The technique has been used for many years at ORNL. ${ }^{1-3}$ In the past, this scheme was used extensively for snowing the design objectives in control systems based on relav iogic. Recently, however, the technique has been successfulij' applied to the construction of block diagrams of complex, computer program logic. The principal advantage of the paraliel logic diagrain is illusiated in Fig. 8.21.1, in which a simplified algorithm displays isyo identical logic functions in both the serial and the parallel logic diagram form. This display makes it apparent tiat the parallel scheme is ideally suited for ascertaining the multiple paths or conditions to a given end stati, whereas the serial logic diagram defines the programming steps more exactly and is consequently more useful than the parallel diagram in verifying that the actual program instructions will perform the desired functions.

When applied to complex programs, the two techniques are a very efficient and compatible method for lucidly documenting the design objectives, the significant variables, and the overall control system logic. Documenting these important factors in a clear, simple manner provides a meaningiul information base on which detailed design, high quality reviews, and operational debugging can be plannea, because, in software 
paraliel logic diagram

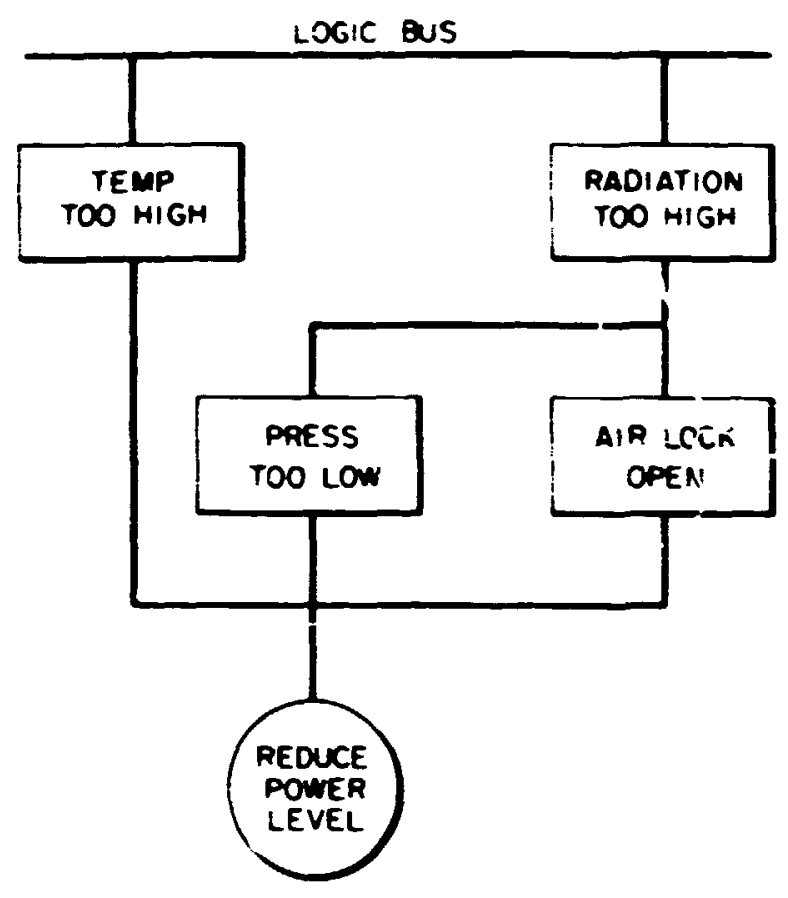

ORNL - DWG 72-1145:

SERIAL LOGIC DIAGRAM

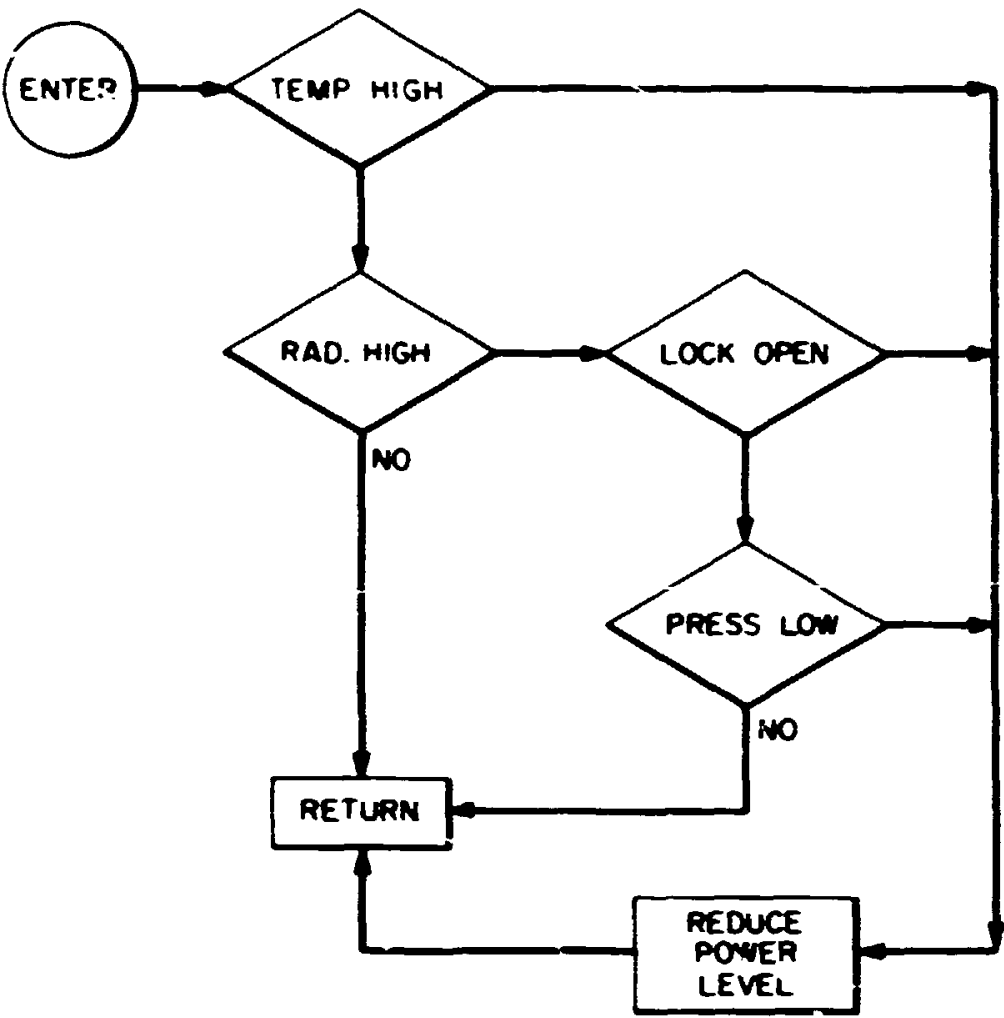

Fie. 8.21.1 Simptifed parallel and sainl boje dingrame

systems. as in conventional system design, the basic man-to-man interface is i major deterrent to the assurance of high quality.

1. F. T. Binford and E. N. Cramer (eds), The High Flux Isorope Reactor, ORill-3572, rev. 2 (June 1968), p. 125.

2. 1. E. G. Bates, Description of the BSR 2-MW Reactor Control and Instrumentation System, ORNL-TM-2400 (October 1967), p. 8.

3. F. W. Sanders et al, Operation Plan and fiazerds Report - Operetion BREN, CEX-62.02 (April 1962), p. 30.

\subsection{REACTOR ON-LINE COMPUTER CONTROL DEVELOPMENT AT THE HFIR. VOL. 1: OBJECTIVES, SYSTEM DESGN, OPERATING EXPERIENCE AND SAFETY CONSIDERATIUNS'}

\section{J. B. Bullock H. P. Danforth}

A description of the HFIR Computer Control development p:ogram is given with details on system specification and procurement problems, operating philosophy and experience, and system hardware performance history. Detailed software descriptions are provided in Vol. 2.

1. Abstract of report OKNL-TM-3679, vol. 1 (to be published).

\subsection{REACTOR DN-LINE COMPUTER CONTROL DEVELOPMENT AT THE HFIR, VOL. 2: PROGRAM LISTINGS, SUMMANIES, AND LOGIC DIAGRAMS'}

\section{J. B. Bullock G. R. Owens W. H. Sides, Jr.}

The computer programs written for the development of reactor coniputer control and surveillance are presented in three !evels of detail. The programs are described in summary form, in logic diagram form. and finally the detailed assembly language listing is presented along with the hexadecimal machine instructions.

1. Aiostiact of published report ORNL-TM-2679, vol. 2 (February 18, 1972). 


\title{
8.24 STUDY OF REACTIVIT BALANCE DURING STARTUP OF THE HFIR'
}

\author{
J. W. Allen ${ }^{2}$ W. H. Sides, Jr
}

The reactivity balance during startup in the High Flux Isotope Reactor calculated by a mathematicai model on a CDC 1700 ontine computer was stadied. The balance was imploved by postulating a ne:v reactivity term due to a power coefficient (te..uperature fezdback) and one due to the burnout of a target poison, ${ }^{135} \times$ e.

1. Abstact of publisthed report: ORNL-TM-3769 (Anzust 1972).

2. Present adtreas: the University of Tensesece, Kroxxille.

\section{Reactor Diagnosis}

\subsection{DYNAMIC EXTERIMIENTS FOR HEAT TRANSFER AND FLOW MIXING STUDIES IN THE FUELFAILURE MOCKUP}
T. W. Kerlin'
D. N. Fry
C. B. Stokes

Temperature-topower frequency response tests were garformed in an electrically heated mockup of an LMFBR fuel awembly to show that analysis of data from ojiamic terts car. yield heat transfer and mixing information that cannot be obtained from steady-state measurements. The additional information from dynamic tests should be particularly helpiul in studying the effects of cooiant channel blockage and also the interchannel flow sweeping effectiveness of wirewrap fuel rod spacers.

The tests were performed at the ORNL Fuel Failure Mockup (FFM), where LMFBR fuel assemblies were simulated by bundles of 19 electrically heated, sodium-cooled rods. Temperatures on the heated rod were monitored by thermocouples embedded in the spiral wirewrap rod spacers; the thermocouple junctions were at points 9 and 21 in. downstream from the entrance to the heated section. Temperature-to-powr frequency response functions were obtained by modulating the electric pciwer to one of the 19 heaters and measuring the temperature response. A pseudoraidom binary test signal provides frequency response results sver a range from 0.1 to $2 \mathrm{~Hz}$. Measurements were made for sodium velocities ranging from 4.4 to $24 \mathrm{fps}$. The data were analyzed to obtain the gain and phase shift between temperature and power and between selected pairs of temperatures.

Interpretation of the shape of the expenmintal results and the dependence on position in the bundle was performed by correlation with results from theoretical models. The ratios of gain response at different flow rates were theoretically predicted using two different models: one model was based on an ascumption of well-mixed flow, and the other on dug flow. A correlation of the experimental results and theoretical predictions sugests that slug flow predominates at the 9-in. point, but well-mixed flow predominates at the 21 -in. point. Also, the low-frequency $(<0.1 \mathrm{H}$ ) predictions were the same for both models, indicating that steady-state measurements cannot indicate whether well-mixed flow or slug flow is predominant.

1. Consultant from dhe Nuclear Engineering Department, the University of Tennevece, Knoxville.

\subsection{ACOUSTIC MEASUREMENTS ON FFM}

R. F. Saxei

Background measurements on the flow in the Fuel Failure Mockup (FFM) loop were made to obtain information for planning boiling experiments. 
Investigations were concentrated to a large extent on the neasurement of the signal-to-noise ratio at different frequencies. The results showed that no advantage was to be gained by using a filter at any given frequency, since the ratio of detection sensitivity to background noise stayed essentially constant and independent of frequency. The measurements showed, however, that the amount of background noise increased rapidly with sodium flow and the spectral distribution stayed approximately constant.

At frequencies above abon! $10 \mathrm{kHz}$, the background noise approximated to a white noise spectrum up to the highest frequency measurable with the present equipment $(600-700 \mathrm{kHz})$. This is consistent with a boundary layer generation mechanism. The amount of background noise is also dependent on the "fuel" assembly within the test section. Inversion of one assembly cause'l a change in the background noise level by a factor of 2 .

These measurements and results of experiments and analysis at North Carolina State University show that no detection advantage accrues from the use of any particular frequency band, and the emission from the first nucleate boiling is expected to be in the form of short duration pulses. Thus, we conclude that for the detection of the first nucleate boiling a pulse detection system is the most logical measuring system. Such a system would preferably encompass a range of frequencies from some tens of kilo-Hertz up to at least $600 \mathrm{kHz}$.

Future experiments using heated "fuel" elements, reduced flow, and partial flow blockages will investigate the onset of boiling using these acoustical techniques.

Recent measurements on a partially-blocked assembly at low sodium flow and with $5 \mathrm{~kW} / \mathrm{ft}$ of electrical heating have showi that the acoustic emissions detected are consistent with a thermal expansioncontraction mechanism of generation. No boiling was detected. Further experiments with blockages are planned.

1. Consultant from North Carolina State University.

\subsection{DETECTION AND LOCATION OF FAILED FUEL IN THE FFTF BY DELAYED NEUTRONS}
R. C. Kryter
D. P. Rcux
A. R. Buhl

An on-line Delayed Neutron Detection and Location (DNDAL) system, in which noise analysis techniques are applied to enhance the detection sensitivity and locational accuracy, is being desigried for the Fast Flux Test Facility reactor. Signaling the occurrence of a fuel cladding rufture through the detection of neutrons emitted from decaying fission products released to the coolant stream is not a new idea. Since there are thiree symmetrically positioned primary-coolant loops in the FFTF, installation of neutron detection and auxiliary data processing instruments will allow location ("triangulation") of fuel-pin failures that result in fission product contamination ("washout") of the coolant stream.

We are investigating both first-moment (ratios of corrected counting rates) and second-moment (variance-to-mean and correlation functions) DNDAL data processing schemes; i.e., we are attempting to utilize both amplitude and arrival time relationships among the counting rates for the individual detector systems that monitor the three coolant outlet pipes. Results from detailed numerical analyses of anticipated counting rates under different operating conditicr; are encouraging in that they predict a detection sensitivity of $\sim 0.4 \mathrm{~g}$ of fuel released, or $\sim 0.6 \mathrm{~cm}^{2}$ of fuel exposed by a cladding breach. The locational accuracy of the DNDAL system is estimated to be 5-10\% of the total fuel inventory; hydraulic flow pattern experiments are being executed to better define locational accuracy and to ascertain sensitivity to reactor vessel hydraulic design modifications. 


\title{
8.28 RRELMINARY COOLANT TEMTERATURE OSCILLATHON MEASUREMIENTS AT THE FUELFAILURE MOCKU?'
}

\author{
D. N. Fry T. W. Kerlin ${ }^{2}$
}

A feasibility study was conducted at the Fuel-Failure Mockup to determine if fluctuations in coolant temperature can be used to study flow and heat transfer mechanisms in a simuloted Liquid-Metal Fast Breeder Resctor (LMFBR) fuel rod asembly. Thermocouple siznals were cross correlated to obtain the gain and phase lag between thermocuuple locations.

The results of gain and phase measurements between wire-wrap thermocouples in bundle 1A show that the effect of wire wraps on the crossflow is experimentally observable. Also, these results, obtained at a frequency of $2 \mathrm{~Hz}$ sugest that the crossflow might be proportional to the 0.8 power of the bulk flow.

1. Abatenct of publithed report: ORNL-M4-3761 (Angest 1972).

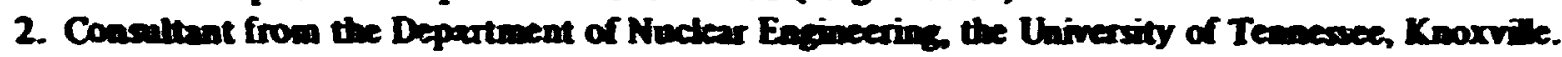

\section{REACTOR SAFETY AND EVALUATION}

\subsection{NUCLEAR SAFETY INFORMATION CENTER}

\author{
E. W. Hagen
}

The program if collecting, evaluating, indexing, storing, and disseminating information selated to instrumentation and electric power associated with nuclear safety was continued.' This material pertains to the saiety of nuclear plants in the categories of protection systerns, operation systems, plant instrumentation, and plant electric power systems. Approximately 1447 documents were reviewed and abstracted for the computerized information retrieval system at the Nuclear Safety Information Center, and 44 direct requests for special tabulations of references or information wire rrocessed for the national and intermational nuclear community during this past year.

1. E. W. Hagen, Instrumentation and Controls Dis. Awne Pros. Rep. Sepr. 1, 1971, ORNL-4734, pp. $106-7$.

\subsection{NUCLEAR SAFETY JOURN 'L}

\author{
E. W. Hagen
}

Publication of Niuclew Safety under the auspices of the Nuclear Information Center was continued.' Responsibility continued for the preparation and editing of material related to instrumentation and control, and four nembers of the Instrumentation and Controls Division authored five of the seven articles [12(5), 12(6), i3(1), and 13(4)] contained in the "Control and Instrumentation" section of Nuclear Safety during the pas year.

1. E. W. Hexe., Instrumentation end Controls Dir. Anmu Prop. Rep. Sept. 1, 1971, ORNL-4734, p. 105.

2. E. W. Hagen (ed.), Nuclear Safety 1245), 496-515 (September-October i971); 12(6), 583-90 (Novembet-December 1971); 13(1), 29-36 (January-February 1972); 1344), 295-300 (July-August 1972).

\subsection{REACTOR AVAILABILTY AND STATION RELABIUTY FOR CONTINUITY OF SERVICE'}

$$
\text { E.W. Hagen }
$$

The average availability of first-generation nuclear power reactors to produce uninternuptibly a supply of thermal energy was determined to be $83.4 \%$ for seven commercially operated electricity-generating 
stations by reviewing the station operating repcrts fr.r a three-yeat period. The safest nuclear power reactor is one that is in normal steady-state operation, swid iherefore it was pertinent to determine the causes of abnormal operation oi unscheduled shutdown. Operational dciations and unplanned station shutdowns were analyzed and categorized into those related to he : $i$-transfer systems, instrumentation and controls, and the electric turbine-generator power system. The cintral problem areas were found to be leaks in the heat-transfer system, difficulties with the control-rod drives in the primary system, and both leaks and iurbine controls in the secondary plant. From the data aviilable a figure of merit was produced to evaluate the unscheduled shutdowns and also to give a comparative evaluation of station service reliability for use of utility operators.

1. Abstract of published article: Nucl. Sefety 12(5), 499-515 (September-October 1971).

\subsection{RELIABILTY-ENGINEERING METHODS IN REACTOR-SAFETY TECHNOLOGY'}

Paul Rubel

Reliability engineering seeks deliberately to increase the likelihood that devices or systems will function as i- tended. To this end, analytical techniques are routinely applied in fields such as aerospace in ways that give rational direction to the various quality-assurance activities. A recent survey of similai applications to enhance reactor safety revealed that, although qualitative-analysis methods have been adopted widely, probabilistic modeling and risk forecasting have beer: somewhat restricted by lack of adequate supporting irformation. Probabilistic analysis use is expanding, however, as current efforts graduiiily overcome the information problem. Meanwhile, quality assurance has benefited from the insight provided by the preliminary risk-evaluation studies.

1. Abstract of peblisired anin:?: Nuct Safery 12(5), 496-99 (September-October 1971).

\subsection{THE FOURTEENTH POWER INSTRUMENTATION SYMPOSIUM OF THE INSTRUMENT SOCIETY OF AMERICA ${ }^{1}$}

\section{$\begin{array}{lll}\text { E. W. Hagen } & \text { G. K. Rhode } & \text { T. G. Bassctt }\end{array}$}

The electric power generation segment of the nuclear field is increasing in size and importance and, therefore, in its responsibilities and need to be heard. Some of this industry's concerns about standards, reliability, communications, and instrumentation and control needs were expressed at the Instrument Society of America's 14th Power Instrumentation Symposium. More standards are still needed, and to resolve some of the r.ajor safety problems now before the industry, several important instrumentation and control objectives must be met. Also communication between the exgineering design and the operating groups sould be improveci.

1. Abstract of published article: Nucl. Safety 13(1), 29-36 (January-Fsbruary 1972).

2. Niagara Mohawt Power Corporation.

\subsection{REPORT TO CONGRESS ON NUCLEAR REACTOR SAFETY}

\section{Paul Rubel}

The US. Atomic Energy Commission was requested by the Joint Committee on Atomic Energy to prepare a comprehensive report reviewing reactor sufety. Material concerning reliability and probabilistic aspects of safety was gathered for Nuclear Safety Information Center participation in preparation of this report. 


\title{
8.35 RELIABILITY STUDIES OF PRLFOSED UNDERSEA REACTOR
}

\author{
Paul Rubel
}

The U. S. Navy-sponsored CRNL program to review small reactor concepts for possible undersea application was continued' through December 1971. Altemative cositrol schemes for the reactor and puwer conversion systems were outlined, and cursory evaluations were made of each regarding potential performance and reliability:

1. P. Rubel, Instrumentation and Controls Div. Annu Prog. Rep. Sepr. 1, 1971, ORNL-4734, p. 106.

\subsection{RELIABILTYY AND SAFETY ANALYSES OF HIGH-TEMPERATURE GAS-COOLED REACTOR SYSTEMS}

Paul Rubel

The HTGR Safet; Program at ORNL is concerned with all aspects of potential radianctivity discharge from gas-cooled reactor plants. Subject to investigation are the basic mechanisms of fission product release and transport, integrity of components, ard plant transient behavior. Program participation was begun in the area of s;stem reliability and accident risk analysis, which is intended to provide a perspective for the other investigations.

Methods were developed whereby the prospects for adequate response of systems under contingency conditions can be examined zonsistently by event tree diagrams and organized information files. Initially, these methards are being used to determine piogram goals and priorities, for example, by identifjing needs for specific studies of plant transient behavior and heiping define parameter value ranges within which to investigate degradation effects. The same studies yield rational bases for design and quality assurance requirements and fumish a general framework for efficient safety evaluation of future plants.

In the absence of desiga- information for the pruposed large plants, the analyses thus far are somewhat speculative. Central to their organization, however, is the capability for continual updating, revision, and acconumorlation of alternative versions of controversial topics. Subsequent work will develop the analyses ipace with the accruing support information.

A formal reliability assesument was completed for the emergency engine-generator system of the Fort St. Vrain Reactiox plant. This work was undertaken as a pilct exercise to demonstrate the applications of reliability meth'ds an 1 to cultivate sources of data and experience for use in future, more extensive studies. The principal analysis tusk was performed by the UKAEA Systems Reliability Service (SRS), to which ORNL subscriles. A report reriewing the SRS work and commenting on other problem aspects wes prepared in draft form.

\subsection{TASK GROUP FOR ECCS COWPUTER CODES REVIEW}

\section{R. S. Stone}

\section{$\begin{array}{lll}\text { F. H. Clark J.P. Sanden' } & \text { J.B. McGrory }\end{array}$}

During the summer of 1972 the U.S. Atomic Enersy Commiscion held hearing in Bethesda, Md., to bring together and evaluate testimony regarding the Interim Acceptance Criteria for Emergency Core Cooling Systems (ECCS). These interim criteria were isaved by the US. Atomic Energy Commixion to provide bases for judging ECCS designs during licessing evaluations of light-water power reactors. Since there are gaps in the knowledge of loss of coolant accident dynamics, the snistria substituted conservatien for rigor. 
Various intervenors attacked the criteria for insufficient conservatism; reactor venciors regarded them as too conservative. The Bethesda hearings were an attempt to resolve the issue. Since ORNL research was involved in many of the technical questions at issue, several ORNL personnel took part in the hearins as witnesses. Also. an ORN! task group was assembled to investigate five technical areas pertinent to ihe hearings and to assess the strengths and needs in each of these areas.

The area assigned to this Division was "Capability of computer codes to calculate the progress of events in a large reactor during a loss of coolant accident." Information was gathered from ORNL experience and from work at other sites, as reported in the ECCS hearings testimony and elsewhere. From this information a position was developed and a report was prepared that summarized the facts and presented a conservative position that is supported by mathematical analysis and experimental data.

1. Reactor Division.

2. Phy ics Division.

\title{
8.38 HYRRID CON UTATION OF FUELTIN BIEATUP IN A PWR LOSSOF COOLANT ACCIOSTIT
}

\author{
R.S.Stone F.H.Clark
}

The digital heat:-un progran THETA was atapted to the hybrid computer. The objective of this work is to apply hybrid lechnigues and machirery to an existing, extensively researched digitil progran to shortea the running time. This was accomplished. The resulting hybrid progrem runs in $\mathbf{0 . 1}$ the time of the betest digital version and permits no-lime interaction between the operator and the simalation.

As a side benefit, during this developinent of a drasically differeat implementation oi the divitul code, the essential correctness of the digitl prograuming wos verified and a few aress where the equations could be improved were noted. This information was particularty important when "Los of Coolant Codes" in general, were being questioned during US. Atomic Energy Commiscion nearinos on Interim Acceptence Eriteria for ExCS (Emergency Core-Cooling Systems).

The hybrid model is being used to provide initial guidence for the experisuent-1 blondom progen: feedbeck from the experimental progrem, as it comes in, will be ued to improve the model. Mis dore coupling of anslysis and experiment is an optimum combination for devekpiass anderstandieg of the dynamics involved in loss of coolamt heat transerer processes.

\subsection{RELWAULTY METEODS ATUED TO REACTOR SAFETY: TRJNDS AND MOGRES'}

\section{P. Rubet}

The present main roles of retiability ensincering methods in reactor safery are to inprove the decien of protection systems and to exhance quality asurmon. This peper reviews the continine efforts to strengthen the credibility of probubitistic safety evabuations and $t 0$ erpend the andysis role in giving

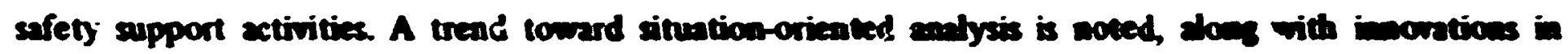
exploiting the limited information avilible for analysis inpat.

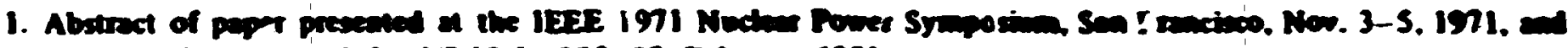

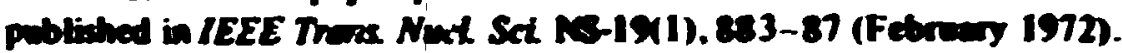




\title{
REACTOR PROJECTS
}

\subsection{HFIR ASYMMETRY RROTECTION}

\author{
W. E. Lingar J. L. Anderson S. J. Ditto
}

Design of a system was stanted that will scram the High Flu:x Isotope Reactor if the control rods become asymmetric under certain unfavorable conditions of power and coolant fluw. The single channel of asymmetry protection now in the HFIR will be improved and expanded to a full three-channel protective-grade system.

The new system will include independen! rod-position sensing. It will also utilize power and coolant flow signats in a logic system to determine the degree of aymmetry that can be tolerated under various operatuny conditions: it wili initiate appropriate action winen permissibie conditions are exceeded.

The circuit motules, now being fabricated in the Division siops, will be installed with the protection system instruments.

\subsection{REDUCTION OF ELCTRONC NOSE IN CURRENT FULSE, RREAMUFIERS}

\section{J. T. De Lorenzo $\quad$ D. P. Roux}

Current-pube preamplifiers (singleended, ORNL model Q-3125; and differentivl imput, ORNL model Q-5059) vere originally dectoped for fiscion counters operating in high guma fields for the LMFBR progrem. ${ }^{1-3}$ Reduction of electronic anise was particalarty desired for high temperature counters where the seutron ibtesu charecteristics are normally poor.

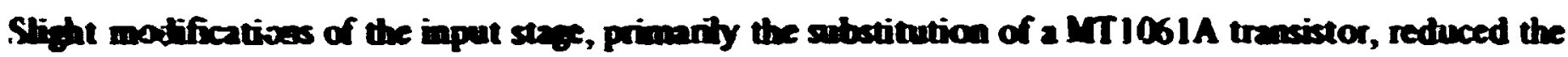
noise threchold for a 10 covedisec bectground from 15.2 to 11.8 threshold units for the single-ended model ad from 163 ro 12.2 for the differentis model. With a bightemperature counter recently lested, this moise reduction permitted operstiva at a lower discriaimator threstold which reselted in a factor of 2 impronenest in exfective neatron sessitivity.

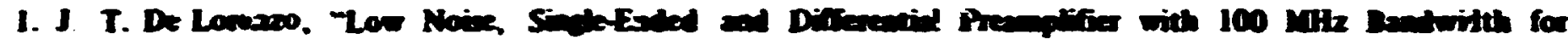

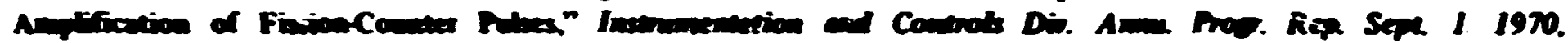
Ondi2-4020.

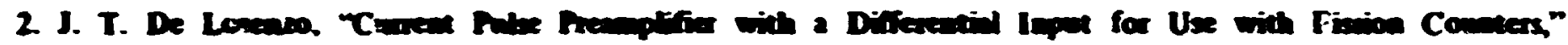

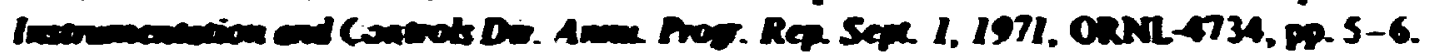

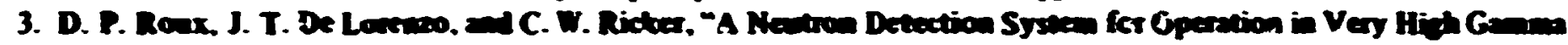

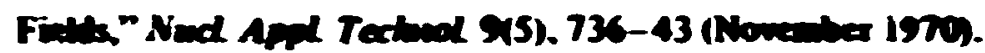

\subsection{FAF CONTIOL ANDSAFTY RSTRUAISTATON}

\section{J. L Anderson}

\section{C.E. Courtery S. J.Ditto B.C. Dusion R.L.Shipp}

Devion and fabrication of additizas and urodifications to the control and protection systems of the Powe Burs Factity (RBP) at the Notional Reactor Testing Stution were contizwed' Becanse of changes in

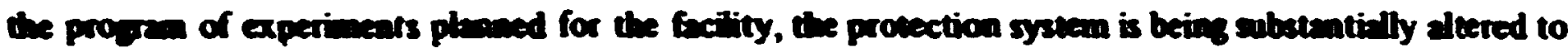

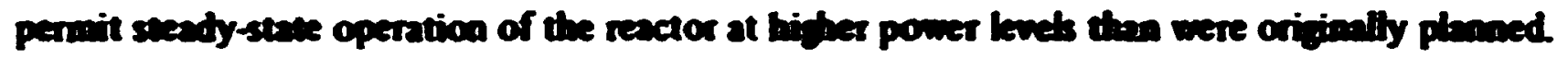

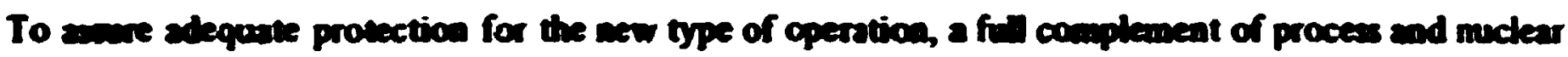

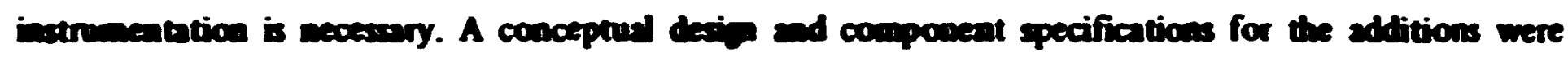
prepared by the Process Instruments Section of this Division and sebmitted to the Aerojet Nuclear Compeny, the facitity contractor-operetor. Aerojet will cosplete the decing detrits and procure the incuruments. 
The process mizsurements for the protection system will include two channels. each. of priman cooiant flow. corc differential pressure. coolant inle! temperature. control-rod cooling air for twelve rods. and reactor vessel coolant level.

The nuclear portion of the protection system will be modified by addition of a time-level safety function, which is related to excessive reactor energy. A fixed power-level trip will be provided for steady-state operation. For shaped-burst operation, the trip level will be raised to selectable higher powers. but only for a period of time that would yield the maximum allowable energy at the selected power. When permitted by an enabling circuit, the power trip levcl will be increased automa:ically from the steady-staie level to the preselected higher value by an auxiliary circuit that will serise the power rise at the initiation of the burst. An electronic timer will jetermine the length of time that the trip level will be elevated. Selection of the elevated power trip point will automatically invoke the maximum time ailuwable for that power level. Misselection of the inip level on an unexpected buist size will result only in an aborted experiment through a premature scram: there will not be a loss of protection. The circuit was designed and fabricated by this Division.

1. J. L. Anderson and S. J. Ditto, Instrumentation and Controls Div. Anse. Prog. Rep. Sept. 1. 197!. ORNL 47 s4, p. 107.

\title{
8.43 TSR-I MODIFICATIONS FOR 1 WW OPERATION
}

\author{
S. J. Ditto \\ B. C. Duggins I. B. Ruble \\ D. D. Waiker K.W. West
}

The control and protection systems of the TSR-II were modified so that the reactor could be operated at $1 \mathrm{MW}$. The authorized maximum power level had been $100 \mathrm{~kW}$, nominal. An important objective of these modifications was to improve the performance ctaracteristius and the reliability of the plani protection system.

The changes included extensive modification of the slow scram system, replacement of thermocoup!es in the plant protection system by resistance thermometers for improved accuracy, and redesign of the systam for protection of personnel. While these changes were being designed and installed, several conditions vere found that indicated a need for additional work. These were reported to the facility operators for their consideration, and the follow-up work was assigned to the Reactor Controls Maintenance Group.

\subsection{MODERNIZATION OF PORTIONS OF THE HIFTR FROTECTION AND CONTROL SYSTENS}

\section{J. L. Anderson C. C. Courtney}

Planning was started to make several changes in the protection ard control systems of the High Flux Isotope Reactor. Components that experience high failure rates or high trouble rates $2 s$ indicated by noise or drift and obsolete components that are no longer manufactured will be replaced. These plans will also allow future addition of functions to the Plant Protection System (PPS).

Operational amplifiers (Q2605) will be replaced with modern reliable amplifiers. The older amplifiers caused occasional noise, oscillation, or erratic operation, primarily because of weas of the mechanical choppers. The new amplifiers will have solid-state, integrated circuits.

The flux reset modules (Q-2603) will be replaced with all electronic reset circuits. The Q-2603 modules, with motor-driven potentiometers to effect a gain change in the system. are susceptible to mechanical 
bounce or poor lectrical contact within the potentiometers and show large noise spikes in the signal outputs. An all-electric system was designed to continuously and automatically calibrate the reactor flux instrumentation.

Two discrete-icimponent, electrometer-type amplifiers, the Flux Amplifier (Q-2602) and the FaultyFuel-Element Detecto: Amplifier (Q-2637), will be replaced with integrated-circuit, îld-effect input operational amplifiers. The older ainplifiers contain obsolete components, and replacicrients a.e unarailable.

Several additional minor circuit changes will be made to improve performance and serviceability. Since the new circuits will be much smaller, the mechanical arrangement will se changed considerably, freeing space for planned future addition of iunctions. Rearrangement of some power distribution will eliminate sev ral power supplies.

\section{4క REVIEW OF STANDARDS AND DESIGN FOR FFTF PROTECTION SYSTEM}

\section{S. J. Ditto J. L. Anderson}

Review of the design of portions of the Fast Flux Test Facility plant protection system was continued i: requested ty the Division of Reactor Develonment and Technology of the U.S. Atomic Eneigy Commission. The design comprised a group of standards that specified the general characteristics of system components and separate ordering data that specified the detailed requirements. Also reviewed was a preliminary analysis of the effectiveness of the reactor shutdown system in responding to reactivity transients. These reviews are being coordinated with a study to evaluate the needs for and benefits to be derived from the use of fast shutdown systems for rea:tors, with emphasis on applicability to LMFBR's.

\subsection{REVIEW OF STATE-OF-THE-ART OF FAST SHUTDOWN SYSIEMS}

\section{$\begin{array}{lll}\text { E. P. Epler } & \text { J. L. Anderson S. J. Ditto }\end{array}$}

A review of the state-of-the-art of fast shutdown systems for reactors was started at the request of the Division of Reactor Development and Technology of the U.S. Atomic Energy Commission. A draft of a state-of-the-art paper was nrepared. This paper describes the history of the development of techniques for achieving fast system response (defined as $\leqslant 30$ to $50 \mathrm{msec}$ ) and discusses the rationale for using such techniques. The operating record of reactors with fast shutdown systems is discussed, with particular emphasis on the effects of fast response on plant availability.

A very important part of the paper will be the discussion of the need for, and the applicability of, fast shutdown: techniqurs in experiniental liquid-metal reactors as well as in large commercial fast breeder reactors.

1. Consultant to the Controls Department. 


\title{
9. Instrumentation for Reactor Division Experiments and Test Loops
}

\subsection{SUPPORT FOR THE SOLID-MECHANICS DEPARTMENT EXPERIMENTAL MECHANICS SECTION}

\author{
R. L. Moore \\ W. A. Bird T.M.Cate C. D. Martin, Jr. R. L. Simps.
}

The Instrumentation and Controls Division furnished about $\mathrm{i}-1 / 2$ man-years of labor for design, application, and maintenance of instruments and instrument systems in support of a variety of experiments undertaken by the Solid Mechanics Department. Four major programs shared in this support effort: Heavy Section Steel Technology, Liquid-Metal Fast Breeder Reactor (LMFBR) Structural Design Methods, ORNL Piping, and Prestressed Concrete Reactor Vessel.

In Support of the Intermediate Vessel Test Series' under the Heavy Section Steel Technology Program, Division personnel assisted in the fabrication, installation, and checkout of all cables for connecting 100 strain gages, 12 thermocouples, and 1 pressure transducer to the Portable Strain Gage Oriented Data Acquisition system pro: ired by the Reactor Division.

Operat: in of the elevated temperature beam test, ${ }^{2}$ one of several test series under thi LMFBR Structural Design Methods Program, revealed a requirement for a precise and programmable load control system during the loading, unloading, and cylical phases of the tests. These requirements were met through the addition of a programmable, closed-loop servo-hydraulic load control system to the test facility. The design was completed and construction is underway on a n£w "circular plate" test facility for this program. This test is identical in concept to the elevated beam test except that the specimen is a circular plate instead of a rectangular beam. All data from strain gages, thermocnupies, load transducers, and displacement transducers will be collected by a computer-based data acquisition system ${ }^{\circ}$

Structural tests performed under the ORNL piping program sequired an increase in the number of channels of strain gage data acquisition available on the data acquisition system. Division personnel ascisted in the procurement, installation, and checkout of 192 additional strain channels and an additional digital magnetic-tape recorder.

Continuing support was provided for the Thermal Cylinder Test under the Prestressed Concrete Reactor Vessel Program. A single-bay instrument panel was designed and built to provide power control and ground fault detec:ion for heaters embedded in the concrete specimen. These will be used to create a hot siot in the test spe imen. Continuing assistance is being given in the acquisition and reduction of data from this test by the previously mentioned data acquisition system. 122.

2. R. L. Moore et al., Ibid., pp. $118-19$.

3. R. L. Moore. T. M. Cate, and C. D. Martin, Jr., Ibid., p. 36. 


\title{
9.2 THERMAL STRESS PIPING 'T" TEST
}

\author{
G. W. Greene
}

In support of the piping technology pregram to obtain data for the design of nuclear piping systems, read-out instrumentation was irstalled to arquire thermal stress data from a heated, 12-in., schedule 80 stainless steel pipe $T$, instrumented with 208 strain gages and 100 thermocouples. Twelve, 25-channel, Dextir data acquisition system analog boxes (eight of which had previously been modified for strain measurement) ${ }^{\prime}$ were used for this application. Additional panelbo. 1 instrumentation was installed to measure and record parameters needed for operation of the facility.

1. R. L. Moore and T. M. Cate, Instrumentation and Controls Div. Anmu Progr. Rep. Sept. 1, 1967, ORNL-4219, pp. 65-67.

\subsection{MISCELLANEOUS SUPPORT FOR THE ENGINEERING SCTENCE DEPARTMENT HEAT TRANSFER AND F UUID MECHANICS SECTION}

\section{J. W. Krewson}

The manpower reouirement fer Instrumentation and Controls Division support of this section, other than that required for the Rod Burnout and Thermal Hydraulic Facility, remained unchanged at about ! man-year, but, due to reallocation of funds, the experiments that were supported were different. Since most of the mclten-salt heat transfer work was no longer funded, there was little need for Division support in this ar:a. The Deformed Rod Bundle Pressure Drop Experiment also operated almost completely without assistance from this Division.

The Heat Transfer Enhancement Experiment was expanded by adding a preheater and by changing the test section so that several rods could be included in the experiment at one time. This unit operated successfully.

The demonstration unit for hyperfiltration with dynamic membranes was completed, in spite of some extremely difficult instrument problems due to high system surge pressures, and it operated with an efficiency approxim'itely three times that expected. The unit was shipped to the field for evaluation.

The "hot-spot" burnout detectors developed for the Red Burnout Facility were installed and checked out successfuliy. The detectors appeared to operate properly during startup operation of the facility, but operation was stopped to permit start of BDHT construction (Sect. 9.5). Consequently, there was no opportunity to properly evalua'e this measurement technique :ial was being considered as a backup for this infrared sensing instrument was never full:' developed because of the difficulty in obtaining an adequate signal from the test model.

Work associated with the detection of pressure and temperature variations on the surface of a heater immersed in liquid metal was continued with some success in detecting temperature variations but none in detecting pressure changes.

Routine assistance was supplied to variour experimenters in response to their continuing requ asts for advice and assistance with instrumentation problems, such as evaluation and improvement of equipment perform ace; analysis of data; and selection, location, and procurement of instruments and equipmicnt. 


\title{
9.4 INSTRUMENTATION FOR A ROD BURNOUT FACILTY
}

\author{
R. L. Moore D. G. Davis B. G. Eads
}

Design and checkout of instrumentation for this facility ${ }^{1}$ was completed and operational checkout was begun.

The checkout was progressing satisfactorily and losp operating conditions were spproaching a point where bumout shouid occur when operations were terminated by a mechanical failure of a braze joint in an eleciiical isolator connector located in an instrument (pressure tap) line. This incident occurred with power applied to the test section and resulted in failure of the test section. Further operation of this facility was terminated, and the facility was shut down to permit modifications to the loop and building to accommodate the larger Thermal Hydraulic Test Facility (Sect. 9.5). The capabilities and most of the equipment in this racility will be included in the Thermal Hydraulic Test Facility.

Althougt no burnout data were obtained, much valuable design information and operating experience were gained, which will aici in design and operation of the enlarged facility. At the time of siutdown all instrumentation was performing acceptably; however, there was evidence that modification of some instruments and controls was needed to improve their performance.

1. R. L. Moore, D. G. Davis, and J. W. Krewson, Istrizmentation and Controls Dir. Annu Prog. Rıp. Sept. 1, 1971. ORNL-4734, p. 117.

\subsection{THERMAL HYDRAULIC TEST FACIUTY}

\author{
B. G. Eads D. G. Davis C. D. Martin, Jr.
}

Modification and enlargement of the Rod Bumout Facility was started for studying blowdown heat transfer (BDHT) on electrically heated, 49-rod arrays that will simulate fuel rods in a section of a pressurized water reacior (PWR) core. Information from these tests is needed to evaluate the effect of a loss-of-coolani type depressurization of a PWR system on the fuel cladding.

The capabilities of, and most of the equipment in, the Rod Bumout Facility will be incorporated in the expanded facility. The changes to be made are:

1. Addition of a new test section containing the 49-rod array.

2. Increase of dc power supplied to the test section from 2 to $7.5 \mathrm{MW}$ (maximum) at $\sim \mathbf{4 0 , 0 0 0 \mathrm { A }}$ (maximum). Two more generators will be installed parallel with the existing two generators, and power will be contr.lled from the parallel combination during blowdown in a manner that will simulate power decay characteristics of a reactor scram.

3. Replacement of two canned-rotor circulating pumps with a new pump capable of delivering $900 \mathrm{gpm}$ (wate-) with a developed head pressure of 525 psi at $600^{\circ} \mathrm{F}$ and 2250 psia.

4. Revision of valving, piping, and controls to permit increased iest section flows up to $600 \mathrm{gpm}$ and to accommodate the excess pressure head inherent in the new pump.

5. Addition of three new heat exchangers and associated controls for removal of the increased power input to the system from the new generators and pump.

6. Replacement of the existing pressurizer with one having a larget voluine and faster response.

7. Addition of a pressure suppression (blowdown) system and associated blowdown lires and rupture disk assemblies to initiate, direct, and receive the blowdown flow. 
The new facility will be capable of operating at pressures from 250 to 2500 psig, temperatures from 250 to $650^{\circ} \mathrm{F}$, and test section power inputs from $30 \mathrm{~kW}$ to $7.5 \mathrm{MW}$. The test section flow will be controllable over a range from 1 to $600 \mathrm{gpm}$.

Revisions and additicns to the instrumentation and controls required for the expansion will include:

1. Removal of instrumentation associated with the existing pump.

2. Addition of instrumentation and contricts for the new heat exchanger and pressure suppression system.

3. Addition of devices for parallel contre! sf the generators during blowdown.

4. Addition of instrumentation to monitor about $\mathbf{4 0 0}$ parameters in the test section, the main loop, and the blowdown system. This will include monitoring as many as 150 rod cladding temperatures, 80 fluid temperatures, 7 pressures, 9 differential pressures, 24 flows, 50 currents, 50 voltages, and 50 miscellaneous process parameters prisr to and during blowdown. Of these parameters, 9 may contain frequency components of interest as high $251000 \mathrm{~Hz}, 20$ as high as $100 \mathrm{~Hz}$, and 250 as high as $5 \mathrm{~Hz}$. The remainder will vary slowly. The pians are to monitor two-phase, bidirectional flows durin:; blowdo:m by means of drag disks, gamma densitometers, and turbine meters.

5. Expansion of the data acquisition system to provide greater capacity and faster response. The plins are to add a 384-channel, high-speed (10,000 point/sec), computer-based, c̈igital data acquisition system and two 14-channel analog (FM) tape-recording systems. The digital system will record low-frequency $(<5 \mathrm{~Hz})$ data, and the FM tape system will also digitize data from the FM tape systems, do off-line data reductions, and perform computations on-site. End-product data will be recorded digitally or magnetic tape in 3 format acceptable to the ORNL Control Computer Facility.

6. Modification of the existing electrical control interlock systems to remove or modify protective interlocks that are no longer needed or interface with blowdown requirements, and (b) to add protective intcrlocks and control circuits for the blowdown function. Instrumentation and controls design is 15\% complete.

\subsection{FORCED CONVECTION DEPRESSURIZATION LOOP}

\section{R. L. Moore J. W. Kreuson}

As part of the Blowdown Heat Transfer Program, the Zircaloy Cladding Failure Test Loop ${ }^{1,2}$ is being reactivated and modified for use in performing blowdown (depressurization) tests with single rods. In these tests, iuss-uf-coolant and pressure accidents will be simulated for light-water reactors with various lengths of fuel rods to (1) obtain data for reactor safety analysis, and (2) determine the similarity between elactrical heater rods experiencing blowíown transients and nuclear fuel rods under similar environmental conditions. These tests will complement the blowdurio testing of multirod arrays io be performed in the Thermal Hydraulic Test Facility.

Present plans are to test $5-1 / 2$ - and 12-ft long rods with both direct (clad resistance) and indirect (intemal) heating. Most of the installed instrumentation and contrils will be usable for these tests with minor modification and additions; only moderate changes of the electrical system supply power will be needed for the $5-1 / 2-f t$ indirectly heated rod in the first test. However, significant revision of the electrical power system will be required ior later tests of the 12-ft indirectly heated rod and for the 5-1/2- and 12-ft directly heated rods. Adeitional instrumentation, sich as drag disk (target) flowmeters, turbine flowmeters, and gamma densitometers will be needed in later tests to obtain data on two-phase (steam-water) flow during blowdown. 
Modification and reactivation of this facility (which has been shut down for a year) are uncierway. The changes to the instrumentation and electrical systems for the $5-1 / 2$-foot rod tests were determined and field revisions were made. All instrumentation is being checked out, repaired, and recalibrated as required.

1. R. L. Moore, T. M. Cate, and C. M. Burton, Insimmentetion and Controls Div. Annu Progr. Ref. Sept. 1. 19;0. ORNL-4620, p. 130.

2. R. L. Moore and T. M. Cate, Instrumentation and Controls Div. Anmu. Progr. Rep. Sept. 1. 1071, ORNL-4734, p. 116.

\subsection{LMFBR THERMAL TRANSIENT TEST LOOP}

\section{G.W. Greene}

The LMFBR Thermal Transient Test Loup wili be used to study the "thermai ratcheting" effect which occurs when stainless steel under stress at high temperatures is rapidly cooled, producing residual stresses that are not completely relaxed during subsequent periods of steady-state, high-temperature operation. Repeated thermal shocks of this type can result in progressive deformations that can degrade the tensile strength of the stainless steel. Data obtainet from these tests will be used to verify analysis techniques applied in the design of LMFBR and FFTF piping vessels and components.

Design and procurenient of instrumentation for this sodium-filled, high-temperature, high-pressure, stainless-steel test facility is $\sim 50 \%$ complete.

The facility will comprise a sodium source tank, pipe nest. replaceable test section, sodium block valve, sodium storage (drain) tank, and gas systems that will supply inert (argon) gas to blanket the sodium and to pressurize the source and storage tank. The test section will contain a test piece machined from RDT stainless stee! seamless pipe. The test piece will be subjected to multiple thermal and pressure cycles until the ratcheting effect becomes repetitive or until a maximum of ten cycles is accurnulated.

Each cycle will consist of a 500-hr holding phase, thermal transient phase, and pressure transient phase. During the holding phase, the sodium block valve will be closed, and temperature and pressure in the source tank, pipe nest, and test piece will be controlled at $1100^{\circ} \mathrm{F}$ and $700 \mathrm{psig}$, respectively. Prior to the transient phase, the temperature in the source tank will be lowered to $800^{\circ} \mathrm{F}$, and the temperature of the pipe nest will be adjusted so that a temperature gradient will be tailored to prcduce a linear temperature transient from 1100 to $800^{\circ} \mathrm{F}$ in the test piece. The transient phase will be initiated by opening the sodium block valve and allowing sodium to discharge from the source tank through the pipe nest and test piece into the storag!: tank at a rate of $\sim 140 \mathrm{gpm}$ for $\sim 30 \mathrm{sec}$. The transient will be terminated by detecting a low level in the source tank and automatically closing the sodium block valve. The pressure transient phase will be periormed by lowering and restoring the source tank and test piece pressures after the system has been refilled and the temperatures and pressures have been restored to holding phase conditions.

In addition to conventional panelboard instrumentation used primarily for operational and pressure safety functions, special instrumentation is being installed to closely control the temperature of the test piece and the pressures in the scurce tank and test piece and to acquire the data. Slow-changing data parameters will be recorded by the Dextir data acquisition system. Faster-changing temperature and pressure data during the transient phase will be recorded by a high-specd data acquisition system or by high-speed recorders. Additional instrumentation will measure stress and criep of the test piece during and following the operational cycles. This instrumentation will include high-tempe:ature strain gages.

An existing facility ${ }^{1}$ is being modified to construct this new facility, and much of the existing instrumentation will be used.

1. C. Brashear and R. L. Durall, Instrumentation and Controls Div. Anmu. Progr. Rep. Sepr. 1, 1971, ORNL-1734, p. 120. 


\title{
9.8 INSTRUMENTATION FOR UMFBR FUEL FAILURE MOCKUP FACILTY
}

\author{
A. H. Anderson, Jr. R. M. Burnett
}

Engineering assistance was continued in the operation of this high-temperature sodium facility for conducting out-of-pile LMFBR fuel element propagation experiments.' An additional 75 channels of Dextir data acquisition were provided to accommodace the additional thermoccuples on the second test section bundle. Funds were approved to provide - new high-speed data acquisition system for the FFM, with connections to be interchangeable between ihis new sysiem and Dextir. Design was started on a 37-rod test bundle to replace the present series of 19 rod bundles.

Work was completed on the scram and alarm system check procedures for the preventive maintenance nanual. Routine calibration and maintenance of instrumentation are cuordinated with the Y-12 parallel computer program.

1. A. H. Anderson, Jr., and R. M. Burnett, Instrumentation and Controls Dis. Amone Progr. Rep. Sept. 1. 1971. ORNL-4734, P. 119.

\subsection{INSTRUMENTATION FOR MSBR COOLANT SALT TECHNOLOGY FACTLTY}

$$
\text { C. Brashear R. L. Durall A. H. Andersca, J!. }
$$

Design and installation of instrumentation and controls for this circulating-molten-salt facility were completed and checkout is in progress. The facility will be used to evaluate sodium fluoroborate eutectic as a secondary coolant for molter: salt reactors. Fifty drawing were prepared for desiga of new instrumentation and modification of instrumentation salvaged from the MSRE. New instrument cabinets consist of six for control and monitoring instruments, one for the Dextir system, one for off-gas instruments, and one for cever-gas instruments. Extensive modifications were made on two cabinets for helium purification and two for oil system instruments from the MSRE. Also, the helium purification and oil system instrumented packages were removed from the MSRE and modified for this facility.

Assistance was provided to the Reactor Division in preparing a description of the final system design.

\subsection{MOLTEN_SALT BREEDER EXPERIMENT DESIGN}

\section{P. G. Herndon}

Development of instrument application diagrams for the MSBE primary-salt circulating system, the secondary-salt circurating system, and the off-gas clearup systems was completed. Further work was postponed indefinitely.

\subsection{INSTRUMENTATION FOR WISBR GAS SYSTEM TECHNOLOGY FACILTY}

$$
\text { P. G. Herndon }
$$

Design and procurement of instrumentation and controls for this circulating-molten-salt facility ware continued, ${ }^{1}$ and the task is now $60 \%$ complete. The facility will be used to evaluate bubble generator and bubble separator designs along with components for off-gas purification and recycle. Components are also available for molten-salt chemistry experiments. Practically all of the instrument components needed in this facility are being salvaged from the MSRE.

1. A. H. Anderson and R. M. Bumett, Instrumentation and Contrals Div. Annu. Progr. Rep. Sept. 1, 1971, ORNL-4734, p. 121. 


\title{
9.12 MOLTEN-SALT FORCEDCTRCULATION LOOS 1 AND 2
}

\author{
G. W. Greene
}

The instrumentation and controls on these two salt loops.' which have accumulated in excess of 6000 and $5000 \mathrm{hr}$. respect :ly. at design conditions, performed satisfactorily during the pest year. Except for some minor modifications and additions, only routine maintenance was required.

The variable-speed pump drive motors on both loops are being replaced with new brishless drive units with solid-state controls. This change will increase system reliability and eliminate electrical interference in other instrumentation caused by arcing commutator brushes in the speed control units.

1. G. P. Greene, Instrumentstion and Controls Div. Amme Prog. Rep Sept. 1, 1971, ORNL 4734, p. 121.

\subsection{ORGANIC FLUID DECOMPOSTION LOOP}

\section{G. W. Greene}

Installation and checkout of instrumentation of this loop, ${ }^{1}$ after having been postponed for severd months, were completed and an operational checkout of the loop is in progress.

1. G. W. Greene. Insm me utarion and Controb Dis. Anwe. Prog. Rep Sept 1, 1971, ORNL 4734, P. 122.

\subsection{AUTOMATK WELDING SYSTEM}

\section{R. L. Moore
W. A. Bird
C.C. Courtney
B. J. Jones
W. R. Miller

This program for development of equipment, welding procedures, and program controls for automatic welding operations in nuclear reactor systems ${ }^{1-3}$ was terminated at the end of FY 1972 after suitable ecripment and procedures had been developsd and the feasibility of autcmatic nuclear quality welding had been derncistrated.

Tasks completed by Division personnel during the past year included the following:

1. Two programmers, assembled by an outside fabricator, using drawings and specifications prepared by Division personnel, were received, checked, and accepted.

2. Final calibration and qualification of the above two programmers and of three programmers previously fabricated in-house were completed. Three of these programmers were shipped 0 the Hanford Exgineering Development Laboratory (HEDi) for construction of the FFTF and one was shipped to the Tennessee Valley Authority (TVA) for construction of the Browns Ferry Re; stor. The fifth programmer, constructed for the AEC Division of Reactor Development and Technology is being held at ORNL.

3. Programmer checkout procedures were prepared.

4. Programmer checkout procedures und circuit descriptions for an operations and maintenance manual were prepared.

5. Engineers from Bechtel Corporation (HEDL) and Browns Ferry (TVA) were trained in the operation and roaintenance of the welding equipment.

6. Two field trips were made to Browns Ferry to assist in setup of equipment and to assist TVA mair.enance personnel with operational and maintenance problems. 
7. Engineering assistance was given by telephone as required in resolve field problems at HEDL and TVA.

8. Severa' additionai modifications were made in the progammer circuit design to improve its performance.

9. All drawings and documentatiuns were revised to inducati asbuilt construction and the latest revisions.

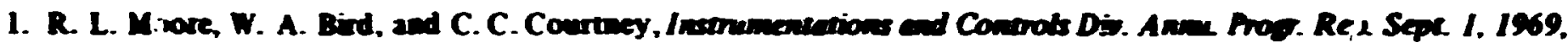
CRNL-MS9, p. 71.

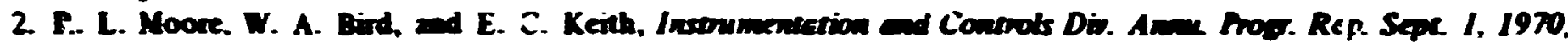
ORNL-4620. p. 72

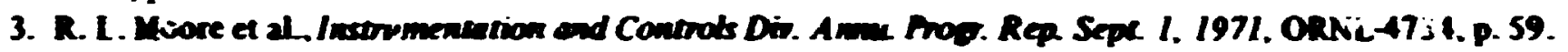

\subsection{MSFNTE HYRID EVANORATOR TXT MODULE RSTRULIJNTATION}

\section{A. H. Malone}

The Office of Saline Water and the Orange County Water District are constructing a hybrid evaporator, sen water deselting plant in Orange County, Fountain Valky, California. The plant is designed to produce 3 million epd of pure water and, after serving as a test facitity, it is proposed to be enlarged to produce 15 million spd. The Laboratory was invited ttrough the Reactor Division to submit a proposel for engincering and procuring the instrumentation required for testing this facility. The Instrinentation and Controls Division submitted an accepted proposel to the Office of Saline Water that included not only measuring instruments but also a complete dava acquisition systenr.

Imstruments for the Orange County unit will mainly measure the pressure, temperature, level, and flow of product, brise, and vapor within and between the stages of the multistage plant.

Most of these devices will produce andog signals that will be scanned, digitized, and either fed to the computer for immediate mathematical axiysis of the operation or stored for future use ind comparative analysis. Some pressures and temperature; will abo be recorded on panel mounted multipoint instruments. Several direct-reading field instnuments suh as sight gases, manorneters. and rotameters will be provided also.

Design of instruments for the system was completed. Procurement is $80 \%$ complete and delivered to the construction site. 


\title{
10. Maintenance and Service
}

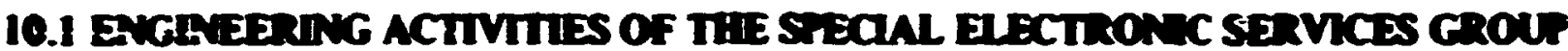

\author{
J. L Lomom \\ A. L. Case C.C.Hbll P.P. Writions
}

The Special Electronic Services Group performs a wide variety of engineering awistance. Amoon tive activities of this group was the assistance given in adppting a FEP-100 videoigrepinic storese termind for signal storace and disply with a photon camera.' A stop-frane and time-bpee video tope recorder was obtained to permit permanent records to be made and for building a library of images. Another activiny was a demonstration io the Biolozy Division of the feastility of adapting a tight microscope to a TV system with time-lapes video recording for observing cell activity.

Paging systems were desioned and installed for the Emviroamental Sciences Divivion in Buildings 3017 and 3504 and interconnected mth Building 2001 so that any building or all buildings can be paged from a centrai point in Building 2001.

Three solidstate closed-circuit TV ystems were specified, procured, and installed at the Tomer Shielding Facility to rephace vacuum tube equipment installed about 1960.

Several temperature response curves were determined for thermocouples using stornge oscillocoope techniques for the LMFBR thermocouple development program. Aswistance was given in making use of a time domain reflectometer to detect thermocouple insulation conditions for the same program.

Cost estimates were prepared for the Physics Division for radiation monitoring instruments and systems for the National Heavy Ion Laboratory. Marked drawingo were supplied to the Ceneral Engineering Division and Plant and Equipment Division for modifying the safety interlock system for the Tandem Van de Granff Accelerator in the High Voltage Recelerator Laboratory (Building 5500).

A variable frequency, O- to 80-Hz, adjustable-vcitage, iv to $120-\mathrm{V}$ power unit $(Q-5146-1)$ was designed and built for use on in-cell induction stirters in the High Radiation Level Examination Laboratory (Building 3525).

1. C. J. Borkowski and M. K. Kopp, IEEE Thans. Nucl. Sci. NS-1913), 161 -68 (June 1972).

\subsection{MAINTENANCE ACTTVITIES OF THE SPECIAL ELECTRONIC SERVICES SHOPS}

\section{J. L. Lovrom R. L. McKinney}

The Specia! Electronic Services group (one foreman and four technicians) staffs shops in the Instrument Laboratory (Building 35C) and the Central Research and Administration Building (building 4500NM). In the Instrument Laboratory, electronic instruments for this Division and specialized instruments irom all areas of the Laboratory are repaired anú calibrated. All Labora:ory oscilloscopes; nuclear instrument modules consisting of scalers, timers, ccunters, discriminators, amplifiers, and coincidence modules; and 


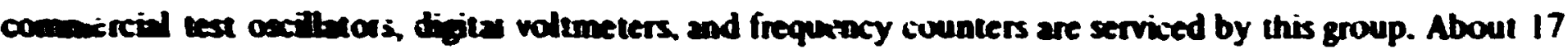
recording spectrophotometers are mintained.

Dre Buidiag 4500NM stop maintains irstruments primarily for the Analytical Chemistry. Chemical Tectaology. Chemiary, and Ptysics Divisions.

Thexe advanred instrvments, with their transistors and sophisticated circuits, require service or repair much las frequently than entier modits. Atoo, a greater number and variety of such instruments are being operated in reseach at the Laboratory. Thus the foremen and technicians that maintain these instruments must be especinlly knowledrestre with rapid diagnostic capability to repair them when defective: otherwise the instrumeats would be in the shop and out of service for a time much lonfer than research persennei

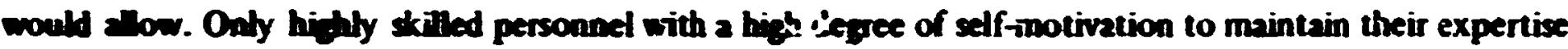
are acoined to such thops These seme persons are sto apable of servicing and repaining other types of dectruic insiruments at weil.

\section{MANTENANCE ACTIVTILS FOR ENVIRONMENTAL SCIENCES AND SOLD STATE DTVEONS AND THE RESETON ENGNEDRING DDARTIENT}

\section{J. L. Lomom W. Ragn}

Four tecinicians suprevised by ane foreman serviced instrumen s for the Environmental Sciences and Solid State Divisions and ine Inspection Engineering Department. The technicians wroked at of two shops, located in Buildings 3001 and 2000 . These services ranged from routine maintenance to fabrication, modification, and repair of complex rlectronic systems. The group acted as liaison between experimenters and various engineering groups of the Instrumentation and Coptrols Division to solve special design problems.

In addition to normal repair and mainterance of two $2.5 \mathrm{NeV}$ electron accelerators, the systems were modified to enable viaual (oscilloscope) inspection of the electron beam at various stages along the beam tube. Majo: modifications were made to the current integrator which measures the total amount of exposure received by a target in the electron beam. A dota loger for the low-temperature experiments in the Bulk Shieldirg kesctor (BSR) was modified and some equipment was added to it so that read-out data not previously avaiiable could be ottained.

Other activities inclusde repair, modification, and field fit.ication for the Neutron Diffraction Group : the High Flux Isotope Reactor, the Oak Ridze Research Reactor, and the Solid State Division Laboratory; for the Superconductivity Group at the BSR; and for the Electron Spin Resonance Group.

Considerable study and diagnositic testing weie required to eliminate noise from an instrument system for the Surfact Studies Group.

An infrarea spectrophotometer was overhauled and installed for the Materials Group of the Solid State Division.

A $\mathrm{CO}_{2}$ analyzer and associated equipment were installed in a trailer for the Environmental Sciences Division for measurement of $\mathrm{CO}_{2}$ given off by Tulip Poplar leavss. A manual-automatic system for raising and lowering sample chambers in an ecoforest was fatricared and installed. It is also used tor study of environmental $\mathrm{CO}_{2}$.

An electronic fish shocker in a watertight enclosure was fabricated for the Ecology 1quati Group.

Several immerscopes and reflectoscopes were completely overtauled, checked, and calibrated for the Inspection Engineering Depariment. 


\title{
10.4 ACTIVITIES OF THE OAK RIDGE ISOCHRONOUS CYCLOTRON (ORIC) INSTRUMENT MAINTENANCE GROUP
}

\author{
J. L. Lowiorn E. W. Sparks
}

Electronic maintenance and modification were provided for the ORIC and its control circuits. There are 42 high-current supplies for the magnetic field ranging from $25 \mathrm{~V}$ at $250 \mathrm{~A}$ to $50 \mathrm{~V}$ at $6 \mathrm{CO0} \mathrm{A}$. Alout 250 NIM modules were maintained. The NIM system greatly facilitates the maintenance by being irterchangeable, having a standard power bin, and being easily accessible. Technicians assisied in interfacing the cyclotron and the computer. Field tabrication war done for the Electron Microscope Project. Maintenance services were supplied for the SEL compiter.

Maintenance and procurement assistance was furnished to the Urivensity Isotupes Separator Oak Kidge (UNiSOR). Emergency instrument mainienance was made syailable to the ORELA on the 4 PM to midnight shift.

Four technicians and a foreman were required for the eleven shifts per week of work.

\subsection{INSTABILITY OF A CYCIOTRON MAGNET SUPPLY}

\section{W. E. Lingar}

Short-term instability of a magnet current supply fabricated elsewhere for the Oak Ridge Isochronous Cyclotron (ORIC) was causing beam fluctuations. An investigation showed that the main cause of the instability was an incorrect gain-phase response of the system loop gain. To correct this problem. design of new electronics for the gain section of the feedback loop is being considered. Another cause of instability was incorrect connections between the reference source, shunt, and low-level differential amplifier.

\subsection{ACTIVITIES OF THE RADIATION MONITORING SYSTEMS MAINTENANCE GROUP}

\section{J. D. Blanton J. L. Lovvorn P. P. Williams}

The maintenance organization of the monitoring system section consists of 13 technicians ard 1 foreman. Activities of this section remained appro;imately as previously reported.

A tctal of 1168 fixed health-pilysics instrument systems are installed throughout the Laboratory. Four technicians performed 1576 services on these instruments in this reporting period. These technicians performed routine bimonthly performanc checks of fixed instruments installed in 13 facility radiation and contamination alarm systerrs, 3 facility alarm and containment systems, and 5 remote radiation alarm systems. The local air monitor and fallout monitor systems were routinely checked semimonthly. A frogram for testing neutron me itors annually for burst performance at the DOSAR facility-HPRR was started.

Three techniciars calibrated and maintained 1324 portable health-physics instruments at the Health Physics Calibration Laboratory. Approximately $\mathbf{4 4 0 0}$ portable instruments were serviced by this group. Two technicians assigned to the Operations Division serviced and maintained approximately 30 gas and 31 liquid-waste-efflient monitors that telemeter alarms and other informatisin to the Waste Disposal Control Center (Building 3105). These two technicians also serviced and maintained instrumerts located in the control center. Routine performance checks vere made on these systeris on a biweekly basis.

Two technicians assigned to the Metals and Ceramics Division :naintained instruments for nondestructive testing. 
There were 797 persunal radiation monitors (PRM) in service. Approximately 202 units were serviced by a technician part time in 1971 .

\subsection{ACTIVITIES OF THE COMPUTER AND ANALYZER GROUP}

\section{E. McDaniel J. A. Keathley}

The computer and analyzer group is staffed by 16 men whose primary runction is to maintain minicomputers, multichannel analyzrrs. liquid-scintillation spectrometers, visual-display terminals, data set nwodulatur-demodulators ("modems"), and their peripheral equipment.

A service group of this type is necessary because of the varied uses of minicomputers at the Laboratory. Here. minicomputers are interfaced with experimental equipment to change parameters or samples, collect data, perform calculations, and output the daia in either printed or plotted form on magnetic tape, or a combination of these. Most of the interfares are designed and built at ORNL for specific needs of the users, resulting in systems that are unique and quite different for each application.

ORNL has 53 minicomputers, and in these system: itıre are 14 different types of digital computers. In addition, ORNL has 15 analog computers that range in size from small units to the AD-4, which is inte.faced to a large digital computer in the Controls Departme.tt of this Division. Three medium-size computers are serviced by this group.

The equipment maintained by this group is as follows:

\section{Equipment No.}

$\begin{array}{lr}\text { Minicomputers and system } & 53 \\ \text { Medium-size computers } & 3 \\ \text { Analog computers } & 15 \\ \text { Multichannel analyzers } & 133 \\ \text { Liquid-scin tillation spectrometers } & 18 \\ \text { Data sets-modems } & 50 \\ \text { Visual-display terminals (computer) } & 6 \\ \text { Teleprinters } & 160 \\ \text { Magnetic-tape transports } & 25 \\ \text { Cal-Comp plotters } & 7 \\ \text { Plotters, general } & 17 \\ \text { Line printers } & 4 \\ \text { Miscellaneous input-output devices } & 226\end{array}$

Electromechanical personnel in this group (four men) maintain all input-output equipment and a large supply of spare parts and modification kits. Two men assist experimenters at experiment sites. Other assistance is supplied from the group when needed.

\subsection{ACTIVITIES OF THE AUDIO-VISUAL SERVICE GROUP}

\section{C. Hall J. L. Lovvorn J. Miniard}

Public address systems, visual-aid projection, and audio and video taping were furnished as requested for 493 in-Laboratory meetings and 14 off-site meetings (5 in Gatinburg and 9 ir. Oak Ridge) during this report period. Three technicians and a foreman were employed full tine, along with borrowed personnel for peak loadings and off-site meetings. About $2000 \mathrm{hr}$ were charged to meetings, and the remaining time was used to maintain and check the Instrumentation and Controls Division audio-visual equipment and similar equipment for other groups. Both audio and vidso tapes were duplicated on request. Audio-visual equipment was inventoried, and inventory records were updated. Equipment beyond repair was sent to salvage or to surplus. The ORNL motion picture group was assisted in recording sound tracks. 
Two 15-mm movie projectors were purchased for use by the Audio-Visual Group. Thesi projectors can be stopped $\mathrm{c} n$ a single frame of the film, and the film can then be moved either forward ur backward, one frame at a tme. The projecior has a $250-W$ tungsten-halogen bulb which is $20 \%$ brighter than a $1000-W$ conventional bulb. Film threading is completely automatic.

Three wireless microphones with three receivers, which operate on three different fri quencies, were purchased. When used with existing equipment, four wireless microphones can be operated at he same time without interfering with each other.

A new lens was purchased for the Transpaque Il transparency projector used in the East Auditorium of Building 4500 . The projector had previously been operated on a projection stand in the aisle of the auditorium, and the new lens was required so that the projector could be operated at the rear of the auditorium.

Interconnecting wiring was installed between the projection booth and stage in both the Central and East Auditoriums in Building $\mathbf{4 5 0 0}$ to allow speakers to advance their own 2- by 2-in. slides during a presentation.

\subsection{LABORATORY RADIO COMMUNICATIONS SYSTEM}

\section{J. A. Russell D. J. Knowles}

The ORNL radio systems were expanded to accommodate the increased Laboratory activities in the environmental and ecological studies, the associated increase in field experimentation and research, and to attain greater operational efficiency at the Laboratory by use of radio communications.

One remote-control consoic, tive mobile units, and three $2-\mathrm{W}$ portable units were obtained and installed on the radiation safety network for the Environmental Sciences Division. One 5-W portable unit was purchased and placed in service on the radiation safety network for emergency communication with the Health Division physician on duty.

A mobile unit on the maintenance network was installed in a Plant and Equipment Division, materials delivery vehicle to improve the utilization of materials delivery service.

An auxiliary, main-base repeater station for the Plant and Equipment Uiv sion network was constructed and installed in Building 3017. This unit will be placed in service if the main repeater station should malfunction. The antennas for this station are located on the $100-\mathrm{ft}$ tower adjacent to the building.

Drawings of the radio systems were updated and revised as necessary for accuracy.

An analysis of the service record and maintenance cost of mobile units for the Plant and Equipment Division network was made. Because of age and maintenance experience, recommendations were made that a number of units be replaced with up-to-date solid-state equipment. A program of evaluation of the effectiveness of all radio communications equipment and recommendations tor the programmed replacement of old vacuum tube equipment is continuing. One of the main aims of this program is to distribute the cost of acquisition of needed replacements over a period of time rather than a single concentrated procurement in one fiscal year.

\subsection{CLOSEDCIRC'JT TELEVISION MONITORING SYSTEP}

$$
\text { J. A. Russell A. L. Case }
$$

A closed-circuit television monitoring system was installed for general-area surveillance and close-up views for use by the Laboratory Protection Division in controlling personnel admittance at gates to two experimental areas in Melton Valley. 
The system consists of two television cameras in environmental enclosures, a inicrowave transmitter, a parabolic dish antenna on a tower. a TV signal up-converter, and a coaxial camera selector switch at each gate. The signal from each gate is transn tted at microwave frequencies to a microwave repeater station on Melton Hill where it is retr.unsmitted an't sent to a microwave receiver at the Guard and Fire Headquarters (Building 25:0). The received signal is down-converted to commercial television frequencies and carried by coaxial cable to moriturs lucated in the building and in the Wes: Portal.

Controls for remotely operating the gate and switching from the general view camera to the close-up came ra are located at the monitors at the West Portal and at Guard Headquarters.

Transmission of control signals is by audio-frequency-shiît tone telemetry, with multiple circuits operaiing on a singie pair ôf telephone lines to each gate.

The commercially manufactured, low-power, solid-state microwave transmission system operates at a power level of $2 \mathrm{~mW}$. The equipment was designed to be used in the transmission of closed-circuit educational TV programs. Consumer-grade, solid-state TV cameras and monitors are used. The system was designed to achieve adequate video information at a minimum cost. $\mathbf{A}$ consider $-b l e$ savings in the cost was realized by using microwave video links instead of a cable-connected transinission system.

\subsection{ACTIVITIES OF THE RADIO, TV, PAGING, AND INTERCOM MAINTENANCE GROUP}

\section{J. D. Blanton \\ $\begin{array}{lll}\text { J. L. Lovvorn } & \text { D. J. Knowles J. A. Kussell }\end{array}$}

There were 282 pieces of radio equipınent in service at the Laboiatory. An instrument technician was assigned full time to service and maintain this equipment. A computerized program was instituted to semiannually perform routine power, frequercy, deviation, and sensitivity performance checks on two-way radio units. Approximately 355 two-way radio units were serviced during 1971.

Quality assurance (QA) received increased emphasis during the year. An "in-house" QA committee audited the radio maiatenance procedures. Recommendations made to improve practices judged inaciiçinte. will be implemented as time permits and new test equipment can be obtained.

One technician serviced and maintained closed - ircuit television. jideo recorders, and paging and intercom systems instriled at the Laboratory.

A total oi 251 radio-paging receivers were in service. Approximately 168 receivers were serviced $u$ y a technician part time during 1971.

\subsection{DESIGN ASSISTANCE :U REACTOR MA INTENANCE GROUP}

\section{J. L. Anderson S. J. Ditto}

The Reactor Projects Group has a responsibility for significant disign changes to the control and safety systems of ORNL operating reactors. These changes are usully made to correct system deficiencies or to meet changing operational requirements and, occasionally, o keep the system up to idte with respect to state-of-the-art developments in the control safety field. In areas where the changes do not involve basic control or safety questions, the group strves in an advisory and review capacity, with the Reactor Maintenance Group providing detailed design changes.

During the current year about 45 design changes were made in the seven operating . actors. Most of these changes were minor. Participation by the Reactor Projects Group served to give con w.1uity to the individual reactor system designs and, equally as important, provided valuable feedback to designers of future systems. This work will be continued at about the same level for some time. 


\subsection{MAINTENANCE OF THE BSR AND THE PCA}
J. M. Farmer
C. F. Holloway
J. B. Ruble
K. W. West

Two unscheduled shutdowns of the Bulic Shielding Reactor during the last 12 months were caused by instrumentation: failure of a relay in the No. 1 safety channel monitor circuit, and failure of a Zener diode in the voltage comparator of a magnet line voltage. These defective components were replaced.

BSR control circuit changes included modification of the $\log \mathbf{N}$ channel chamber power supply to enable monitoring the $\log \mathbf{N}$ channel chamber lears and addition of voltage monitors to moniiur the output voltages of the modular power supplies associated with the magnet control lines.

A new radiation monitoring system with a lange from 0.1 to $10^{5} \mathrm{R} / \mathrm{hr}$ was installed in the BSR high bay, and dual channels of instrumentation were installed to monitor the building rentilation system.

The Pool Critical Assembly was continued as an experimental facility for intermittent use by the University of Tennessee, the University of Kentucky for student training, and the Tennessee Valley Authority for operator training. It has performed satisfactorily.

\subsection{MAINTENANCE OF REACTORS OPERATED BY THE NEUTRON PHYSICS DIVISION}

\section{D Walker J. B. Ruble K. W. West}

Engineering assistance was furnished to design and modify the reactor control systems of the Tower Shielding Reactor (TSR-II) to permit operation to a power level of $1 \mathrm{MW}$. The reactor control and safety systems were reviewed in detail, and about $\mathbf{S 0}$ control and instrument drawings were updated prior to the design changes for 1-MW operation.

Minor inodifications were made to the $\log \mathbf{N}$ amplifier to climinate a noise problem, the magnet amplifiers to assist in latching the control rods, the servo system to improve its response, ind a number of the control circuits to improve operator convenience and operability. The SNAP-10A instrumentation and controls system performed satisfactorily. The modifications made to the TSR-II personnel protection systems we:e also made to the SNAP-10A.

A number of failures of the No. 1 counting channel in the Health Physics Research Reactor (HPRR) are being corrected by replacing the moveable chamber with a fixed chamber in a newly designed thermalizer. Otherwise, the instrumentation and controls system performed satisfactorily.

\subsection{MAINTENANCE OF THE ORR}
J. M. Farmer
C. F. Holloway
J. B. Ruble
K. W. West

Two unscheduled shutdowns of the Oak Ridge Recearch Reactor during the last 12 months were caused by instrumentation: one because a metal covei tell off a recorder slide wire when the recorder door was opened, and the other because a process-water radiation monitor detector failed and gave erroneous inforniation to several adjacent channels that also display information concerning effluent radiation levels. In the latter case, the defective detector was replaced, and, later, the filters in the detector lines were replaced with filters having improved shielding so that interaction between channels due to magnetic coupling would be reduced almost to zero.

Reactor control circuit changes included (1) addition of equiprisent sn :ilat the period channel chamber leads cuuld be monitored, and (2) removal of pressure switches from the reactor setback circuit. The latter change was made to eliminate unnecessary reactor shutdowns which occurred when the steam pressure to 
the back-up ste:um turbine became too low and overrode the primary electricial motor that drives the building ventilation fan in the stack area. In such cases. the back-up system reduced the reactor power even when the electric motu: was operaing properly.

Extensive preparation, changes, and instrument calibration were required to install two new experiments for the Reactor Division and four new experiments for the Metals and Ceramics Division. In addition, the experiments in operation were maintained.

\subsection{MAINTENANCE OF THE HFIR}

\section{S. Asquith C. T. Carney $\quad$ K.W. West}

The maintenance program previously reported was continusd. Mainicr:ance persunnel continued to gain more experience with the system and to increase their diagnostic ability when faced with equipment malfunctions or abnormal conditions. This incr ased proficiency, redundant instrunents, and interchangeability of NIM modules have enabled til: technicians to perform most of the routine plant maintenance on-line with the reactor operating. Preventive maintinance capability was also improved so that through careful scheduling less than $10 \%$ of th: programmeu maintenance work required reactor shutdown.

Spurious trips caused by a mechanically driven potentiometer in the flux reset module contiried to occur in the safety channels. During the year, an unscheduled shutdown (trip) sccurred four times during routine on-line testing of the safety channels when the second of three channels in the two-of-three coincidence system was tripped. Although the cause of a fifth unscheciuled shutdown, when the No. 4 shim-safety plate dropred, was not determined, it was attributed to instrument failure, possibly electrical noise spikes. These shutdowns accounted for $0.547 \mathrm{hr}$ of a total $210.130 \mathrm{hr}$ of inscheduled reactor downtime.

Redesign of several instrument modules used in the safety, servo, and wide-range counting channels was started. Prototypes of the flux reset medules and the operational amplifiers were placed in temporary service and appear to perform satisfactorily. Other modules will be combined, utiuzing modern and less expensive components with no sacrifice as to the reliability of the system.

A new ionization chamber (PCP III, type 104A) was placed in service in the channel 3 position. Characteristic curves were obtained over a three month period, and the chamber has been accepted as a replacement for the PCP II-104 ionization chamber.

Woik was started to make minor revisions to the experiment " $X$ " pane! which is used to connect experiments to the reactor control system. The primary objzctive is to reduce the sumber of control room annunciators required by each experiment and to clarify the meaning of certan monitoring lights on the " $\mathrm{X}$ " modules.

Experience utilizing the HFIR computer for rod time-of-flight measurements was favorabie. Originally these measurements had been made with electronic digital timers, but later, the circuits were modified to enable simultareous use of the computer and the digital timers. The final stage was recently completed, additional circuits were changed, and the primaiy responsibility for rod time measurements was assigned to the computer, with the digitai timers $x$ 'ailable as a back-up system only.

1. D. S. Asquith, C. T. Carney, and K. W. West, Instrumentation and Controls Div. Annu. Progr. Rep. Sept. 1, 1971. ORNL-4734, p. 83. 


\subsection{CURRENT LMITER FOR DEFECT ETCHING MACHINE}

\section{J. T. De Lorenzo T. V. Cook ${ }^{1}$}

A currert limiter circuit was installed on the output of a defect etching machine for the Meta!s ard Ceramics Division. This circuit prevents the etching electrode from sticking, resulting in more uniform etching and enabling unattender operation of the machine. The circuit samples the output current of the machine (a capacitor-discharge t; pe) and applies a resistive shunt when the current level could precipitate sticking.

1. Metals and Ceramics Division.

\subsection{PURCHASE CONTRACT FOR DIFFERENTIAL, CURRENT-PULSE PREAMPLIFIER}

\section{J. T. De Lorenzo}

A purchase contract for five differential, cuirent-pulse preamplifiers was negotiated. The preamplifier design will conform to RD: Standard C15-3T (July 1971), and the unit cost will be \$1200. The total engineering charge will be $\$ 13,200$. These preamplifiers will be used to design and test components for low-level neutron detection instruments for the Fast Flux Test Facility (FFTF). 


\section{Ecological Sciences Studies}

\subsection{UNDERSTANDING THE DYNAMIC BEHAVIOR OF RADIONUCLIDES RELEASED TO THE ENVIRONMENT AND IMPLICATIONS ${ }^{1}$}
S. I. Auerbach ${ }^{2}$
S. V. Kaye ${ }^{2}$
D. J. Nelson ${ }^{2}$
D. E. Reichle ${ }^{2}$
P. B. Dunaway ${ }^{2}$
R. S. Booth

The enyironmental behavior of radionuclides released to -quatic and terrestrial ecosystems from both routine plant operations and tracer experiments at Oak Ridge National Laboratory (ORNL) has been studied by ecologists during the past 15 years. Two important aspects of these continding studies are: (1) radionuclides used as tracers in the environment help to delineate complex ecological processes and (2) radiolabels quantifying rate processes provide primary ecological information for developing dynamic models of radienuclide transfers to man. Systems analysis techniques are being used to simulate the environmental behavior of radionuclides.

Chro!:ic releases of small quantities of radionuclides to White Oak Lake and the Clinch River havi? provided a unique case study of the environmental behavior of several radionuclides. Radionuclides accurring regularly in organisms from White Oak Lake include ${ }^{90} \mathrm{Sr},{ }^{137} \mathrm{Cs},{ }^{60} \mathrm{Co}$, and ${ }^{3} \mathrm{H}$. Occasionally, ${ }^{106} \mathrm{Ru},{ }^{125} \mathrm{Sb}$, and ${ }^{65} \mathrm{Zn}$ are found. Because of dilution, only ${ }^{90} \mathrm{Sr}$ and ${ }^{137} \mathrm{Cs}$ are regularly detectable in the Clinch River. Coupling of field and laboratory data on selected radionuclides in fish, aquatic insects. mollusks, and crustaceans provides the necessary parameters for dyramic models of radionuclide movements in aquatic ecosysterns.

Research in terrestrial ecosystems has imphasized the biogeochemical cycling of fission products in forest, grassland, and old-field ecosystems. Radionuclide dynamics $\left({ }^{60} \mathrm{Co},{ }^{90} \mathrm{Sr},{ }^{95} \mathrm{Zr}{ }^{95} \mathrm{Nb},{ }^{106} \mathrm{Ru},{ }^{137} \mathrm{Cs}\right.$, and ${ }^{144} \mathrm{Ce}$ ) in aatural plant communities have been followed where soil reac:ion products have formed. Plant translocation and food-chain studies with ${ }^{22} \mathrm{Na},{ }^{42} \mathrm{~K},{ }^{45} \mathrm{Ca},{ }^{85} \mathrm{Sr},{ }^{86} \mathrm{Rb},{ }^{131} \mathrm{I}$, and ${ }^{137} \mathrm{Cs}$ have detailed pathways and fluxes of additional radionuclides in these ecosystems. Research has provided insight anto the budgets and turnover times of major nutrient elements and potentially hazardous radionuclides in contrasting ecological systems.

The results of 15 years of environmental research at ORNL strongly suggest that the dose necessary to evoke an unequivocally detectable biological response is considerably greater than that resulting from maximum permissible concentrations in the environment.

1. Absiract of paper presented at the Fourth International Conference on the Peaceful Uses of Alomic Fnergy. Sept. 6-16, 1971, Geneva.

2. Environmental Sciences Division. 


\title{
11.2 MODELING THE ENVIRONMENTAL REHAVIOR OF RIDIONUCLIDES AND ESTIMATING DOSES TO MAN'
}

\author{
M. J. Kelly ${ }^{2}$ \\ R.S. Booth S. V. Kaye ${ }^{3}$ P. S. Rowher
}

One objective of the health physics work at the Oak Ridge National Laboratory is to make realistic radiological safety assessments of Plowshare projects. The methodology for making such assessments involves dynamic modeling .echniques or syster.s simulations. These systems simulations vary from generalized models that can be applied to many terres:rial locations and all radionuclides to models that can be applied to individual nuclides of particular importance in special situations.

Three nodels illustrating the scope of this program are disiussed in detail in subsequent sections. Two of these modals apply to possibla Plowshare excavation projects, and the third is unique to natural gas stimulation by contained nuclear explosions. 1971.

1. Introduction of paper presented at the Third Session of U.S.-U.S.S.R. Technical Talks on Plowshare. July 12-22.

2. Reactor Chemistry Division.

3. Environmental Sciences Division.

\subsection{APPLICATION OF ENVIRONMENTAL SYSTEMS ANALYSIS TO THE RADIOLOGICAL SAFETY ANALYSIS OF RELEASES TO THE ENVIRONMENT}

E. G. Struxness'
R. V. O'Neill'
S. V. Kaye'
R. S. Booth

This report shows how to use environmental systems analysis to identify important radio:iclides, pathways, and population groups by predicting concentrations that might reach or expose man fcllowing release of radioactivity to the environment. The report was prepared for consideration by Conunittee 4 of the International Commission on Radiation Protection, and will be presented to the committee by Struxness.

1. Envirorimental Sciences Division.

\subsection{RADIONUCLDE TRANSFER TO MAN THROUGH AQUATTC PATHWAYS}

\section{R. S. Booth}

Published literature was surveyed extensively as a first step in preparing a time-dependent, systems analysis model to predict the transfer to man of any radionuclide after deposition in an aquatic ecosystem. Optimum use will be made in the model of hioxcumulation factors, energy and biomass uptake rates and turnover rates. stable elemental concentrations. aquatic harvest data. and critical pathway analysis. The model will be used to predict doses to inan from transient, accidental. or chronic releases of radioactivity to aquatic systems.

\subsection{DEVELOPMENT OF A GENERAL AQUATIC MOTEL}
R. B. O'Neill'
R. S. Booth
H. H. Shugart'

The ambitious task of developing a complex model for mass or carbon transfer in an aquatic ecosystem was initiated by the Central Modeling Group of the International Biological Program (IBP). The model 
includes nunlinear coupling; environmental switihes; complicated birth, teeding, behavioral. and murtality relationships: and detailed correlations between environmental parameters such as temperature and biological processes. The model is intended to illustrate the state of the art in ecosystem modeling and to present hy;iotheses about the relationship between invironment parameters. organism response, and ecosystem dynamics.

The first steps in this model development involved construiting four submodels by working with IBP researchers at Lake George, New York (zooplankton and decomposition), and Lake Winga. Wisionsin (fish and rooted macrophyte). These submodels will be available as memo reports and collated io form part oi the general aquatic model.

1. Environmental Stiences Division.

\title{
11.6 EXPERIMENTAL ANALYSIS OF A MESIC FOREST ECOSYSTEM"
}

\author{
R. V.O'Neill ${ }^{2} \quad$ D. E. Reichle ${ }^{2} \quad$ J.S. Olson ${ }^{2}$ \\ R.S. Booth P. Sollins ${ }^{2}$
}

Analysis of ecosystems must emphasize the dynamic aspects of ecosystem processes involving the flux of materials within and between subsystems. Such research is particularly applicable to assessing the fate of toxic materials in the environment. Radioisotope tracers, used to measure rate coefficients for fluxes, and systems analysis techniques, for developing predictive ecosystem models, are important tools for execution of successful ecosystem research programs. In 1962 the Ecological Sciences Division of Oak Ridge Nationai Laboratory initiated a major project to elucidate and model ecosystem processes of a mesic, deciduous forest landscape by tagging a forest domirated by Liniodendron r:iapifera with cesium-137. The objectives of the research were to develop predictive ecosystem morels of the behavior of hazardous elements. particularly radionuclides, in forest landscapes. Included within the oveiall research design are special experiments for studying: (a) cycles and rates of cyclinz of cesium and related elements. (b) nutrient and energy dynamics utilizing cesium as a radiotrajer, and (c) specific ecosystem processes such as primary produc:i in, canopy grazing, and litter decisniposition. After nine years of intensive research on state variables and transfer coefficients. final staze:; of synthesis involve meshing of subprocess models in development of a total ecosyst :m model describl ig the dynamics of this forest ecosystem.

1. Abstract of a peper presented at the Eastem Deciduous Forest Biome Symposium, December 26-31, 1971, Fhilodetphin, as part of the annual meeting of the Ameri in Asocintion for the Advancement of Science.

2. Environmental Sciences Division.

\subsection{ANALYSIS OF THE FORAGE-COWAMOEL INCORPORATED INTO THE HERMES COMPUTER CODE'}

\section{R. S. Booth}

The HERMES model, developed for use in the "year 2000 study," was evaluated. The ORNL review of the forage-cow-pathway component of this model yielded valuable information that can be incorporated into a model similar to HERMES to be done for the section of the country influenced by the operations of Tennessee Valley Authority.

1. j. F. Fletcher and W. L. Dotson, HERMES-A Digital Computer Code For Estimating Regional Radiological Effects From the Nuclear Power Industry. HEDL-TME-71-168 (December 1971). 


\title{
11.8 A CUMULATIVE EXPOSURE LNDEX (CUEX) FOR ASSESSINT ENVIRC NHENTAL RELEASES OF RIDIOACTIVITY ${ }^{1}$
}

\author{
S. V. Kaye ${ }^{2}$ \\ $\begin{array}{lll}\text { R.S. Bow:h } & \text { P. S. Rohwer } & \text { E. G. Struxness }\end{array}$
}

The Cumulative Exposure Index (CLEX) is being developed to facilitate efficient realistic assessment of environmental releases of radioactivity. The aim of CUEX is :o assess the release on the basis of time integrated radionuclide concentrations measured in suitable environmental sampling media. Typizal measurements would be inncentrations of radioactivity in air or water or on the land surface. The measured concentrations are assessed against basic radiation safety standaids recommended for members of the public

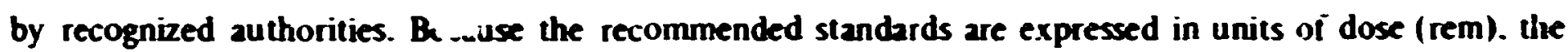
CUEX index. of necessity. embodies environmental models and dose models to ionvert the measured envirenmental radionuclide concentrations into estimates of radiation dcse to man the final estimate of dose and dose commitment used in calculation of CUEX includes contributions for exch radiontuclide and exposure mode of significance and is compared to the appropriate radiation dose limit to complete the assessment. As proposed in ihis paper. CUEX is a more appropriate index to apply to exposures of the public than are the MPC's (maximum permissible concentrations). A schematic is presented for applying CUEX to n!clear plant siting. using environmental systems analysis techniques to model the movement of radionuclides.

1. Abstract of paper presented at Symposium on Revioecology Applied to the Profection of Jan and his Emironment, September 7-10, 1971. Rome.

2. Environmental Sciences Division.

\subsection{A COMPENDIUM OF RADHONUCLIDES FOUND IN UQUID EFFLUENTS OF NUCLEAR FOWER STATIONS}

\author{
R. S. Booth \\ $\begin{array}{lll}\text { S. V. Kaye } & \text { M. J. Kelly } & \text { P.S. Rohwer } \\ & \end{array}$
}

While assessing the radiological impact of several nuclear power stations (for inclusion in Environmental Inpact Statements under preparation by ORVL for the U.S. Atomic Eleergy Commissionit). we noted that utilities use dissimilar source terms for liquid releases. even wheri the reactors are of the same type and power level. Some lists are too extensive. even including parent radionuclides whose radioactive half fives are on the order of minutes and those whose released rates are too low to have any impact ( $\approx$ pCíyear). However, a more common situation is a list that does not include radioniuclides which. from examination of the radioaxtive waste system. would be expected in the liquid effluent. Since oversight of an important radionuclide could lead to an errorivous radiological assessment. and the radiological assessment of each of the several hundred radionuclides puscibly released is impractical. we concluded that there should be a standard list of radionuclides to include in the liquid source term for Environmental Impaet Statements.

Deciding which radionuclides should be on this list, however, is only part of the information: needed by the health physicist to perform a radiological assessment. He must also have some way of checking the predicted release rates against measurements. converting these release rates to potential dose rates to man and to the biota. and checking his determinations of critical pathways and critical radionuclides by comparison with a similar ranking of the radionuclides for typical release rates and environmental situations. This rejort is an attempt to bring together the information needed to make a radiological assessment for radionuclides included in our proposed list. The ir formation listed in this report is meant to 
complement and supplement the values of maximum permissible concentrations in water (MPC) $)_{w}$ for radiolugical assessments.

i. introduction to published report ORNL-TM-3801.

2. Environmental Sciences Division.

3. Reactor Chemistry Division.

\subsection{ENVIRONMENTAL IMPACT STATEMENTS}

R. S. Booth

Considerable time was spent in writing the radiological sections of environmental impact statements (utility-owned nuclear power stations) prepared by the Laboratory for the U.S. Atomic Energy Commission. These radiological assessments utilized site specitic population data, meteorological observations, hydrologic dilution data, food-chain pathway models, etc., to predict doses to individuals (rem) and populations (man-rem) that result from the radicactivity released from nuclear power stations under nornal operating conditions.

\subsection{A SIMPLE SYSTE!S MODEL FOR IDT AND DDE MOVEMENT IN THE HUMAN FOOD CHAIN ${ }^{1}$}

\section{O. W. Burke R. V. O'Neill ${ }^{2}$}

A model to simulate the movement of DDT and DDE in human food chains was developed on an analog computer. The adequacy of the model was verified by its ability to use the amounts of DDT sold in previous years as inputs and to produce outputs that agreed reasonably well with recorded data. Using postulated sales of DDT for future years as input, the model predicted the levels of DDT and DDE in r.an for these future years.

1. Abstract of published rtorst ORNL-IBP-71-9 (November 1971).

2. Ecologeal Scirice: Division. 


\section{Professional Awards and Achievements and Offices and Memberships of Professional Groups Held by Instrumentation and Controls Division Personnel}

\section{AMERICAN INSTITUTE OF ELECTRICAL AND ELECTRONICS ENGINEERS (IEEE)}

R. K. Abele: Member of Nuclear Instruments and Detectors Committee under Nuclear Science Group

J. L. Blankenship: Member of Nuclear Instruments and Detectors Committee, Symposium Committee, and Program Subcommittee under Symposium Committee, all of Nuclear Science Group

S. J. Dittc: Member of Joint Committee on Nuclear Power Standards of Nuclear Science Group and Power Group and Member of Subcommittee SC-5, Reliability, under the Joint Committee

J. H. Holladay: Vice-Chairman of the Oak Ridge Section

C. F. Holloway: Member of Subcommittee SC-4, Auxiliary Power Systems, under Joint Committee on Nuclear Power Standards of Nuclear Science Group and Power Group

J. L. Lovvorn: Director, and Chairman of the Educational Activities Committee of the Oik Ridge Section

J.W. McConnell: Member of Executive Committee of the Oak Ridge Section

\section{AMERICAN NUCLEAR SOCIETY (ANS)}

J. L. Anderson: Member of Subcommittee ANS-4, Reactor Dynamics and Control, Standards Committee

C. J. Borkowski: Fellow

J. B. Bullock: Chairman of Digital Computer Control Planning Group for Subcommittee ANS-4

D. N. Fiy: Member of Nuclear Reactor Safety Committee

\section{AMEFICAN SOCIETY FOR TESTING AND MATERIALS (ASTM)}

W. W. Johnston, Jr.: Member of Committee E-20, Temperature Measurement, and Subcommittees and Sections under this Committee, as follows:

Chairman of E20 Ad Hoc Committee for Conversion of RDT Standards to ASTM Standards

Chairman of Committee E20.03, Resistance Thermometers

Member of Committee E20.04, Thermocouples

Member of E20.04.01, Standardization of Standard Thermocouples and Materials, under Com nittee E20.04

Member o, E20.04.04, Standardization of Nobel Metal Thermocouples and Materials, under E20.04.01

Member of E20.04.03, Metallic Sheathed Thermocouples for Nuclear Service, under Cornmittee E20.04

Member of E20.04.06, Thermocouple Applications, under Committee E20.04

Member of E20.04.07, Insulating Materials is: Thermocouples, under Committee E20.04 
Member of E20.04.10, Sheathed Electrical Heaters for Nuclear Applications, Inder Committee E20.04

R. L. Shepard: Chairman of Subcommittee on Acoustical Thermometry, undei Committer E-20. Temperature Measurement

\section{APOLLO ACHIEVEMENT AWARD FOR SIGNIFICANT CONTRIBUTIONS TO ACTIVITIES ASSOCIATED WITH THE FIRST LUNAR LANDING}

R. J. Fox

V. A. McKay

R. T. Roseberry

T. F. Sliski

R. E. Wintenberg

FIFTH SYMPOSIUM ON TEMPERATURE-ITS MEASUREMENT AND CONTROL IN SCIENCE AND INDUSTRY-JUNE 1971, WASHINGTON, D.C.

W. W. Johnston, Jr.: Member of Thermocouple Committee

R. L. Shepard: Chairman of Omnibus Thermon. etry Committee

Member of Thermocouple Committee

Member of Editorial Committe: for Proceedings Publication

INSTRUMENT SOCIETY OF AMERICA (ISA)

H. E. Cochran, Conunanuer: Exacutive Officer of Research Company 6-3 of the U.S. Naval Reserve

C. S. Lisser: Chairman of the Control Centers Comnittee SP-60

\section{INTERNATIONAL ELECTROTECHNICAL COMMISSION (IEC/TC-45)}

J. L. Blankenship: Member of Detectors Working Group (WG-9)

\section{NATIONAL COUNCIL ON RADIATION PROTECTION AND UNITS}

F. H. Clark: Consultant

\section{ORNL DIRECTOR'S REVIEW COMMITTEES}

B. G. Eads: Accelerator and Source Safety

B. C. Duggins: Reactor Operations

B. Lieberman: Radioactive Operations

J. A. Russell: Accelerator and Source Safety

SOCIETY FOR NUCLEAR MEDICINE

F. H. Clark: Chairman of Computer Hardware Standards Committee

J. W. Woody: Member of Computer Hardware Standards Fommittee

\section{U.S. ATOMIC ENERGY COMMISSION NIM-CAIMAC COSMMITTEE}

N. W. Hill: Member of Subcommittee on Analog Signals

G. A. Holt: Member of Executive Committee

J. W. Woody: Member of NIM Committee 


\section{UNITED STATES OF AMERICA STANDARDS INSTITUTE (USASI)}

D. J. Knowles: Alternate Member with F. W. Manning on Committee N-42, Nuclear Instrumentation

J. W. Krewsun: Member of Subcommittee on Liquid Level under Committee B-88, Calibration of Instruments

F. W. Manning: Member of Committee N-42, Nuclear Instrumentation

\section{Publications}

Some of the publications lisied below were prepared jointly with members of other divisions and with consultants and other nonemployees. Their affilitations are footnoted.

Ackermann, N. J., Jr., J. R. Penland,' and S. H. Hanauer," "A Space and Energy Dependent, Four-Nodal Point Neutron Fluctuation Theory," Trans. Amer. Nucl. Soc. 14(2), 854 (October 1971).

Ackermann, N. J., Jr., and A. R. Buhl, "The Detection Fificiency Dependence of Subcriticality Measurements by the Polarity Spectral Coherence Method," Nuct. Technol. 12, 320-23 (November 1971).

Ackermann, N. j. Jr., "Subcriticality Measurement in an LMFBR," Nucl. Safety 12(6), 583-90 (November-December 1971).

Ackermann, N. J., Jr., D. P. Roux, W. T. Clay, and G. C. Guerrant, “A Low Level Neution Flux Monitoring System for LMFBR's," Trans. Amer. Nucl. Soc. 15(1), 42: (June 1972).

Ackermann, N. J.. Jr., A. R. Buhl, and D. P. Roux, LMFBR Subcriticality Measufement System Developmert, ORNL CF-71-9-45 (September 30, 1971).

Allen, J. W., ${ }^{2}$ and W. H. Sides, Jr., Study of Reactivity Balance During Startup of the HFIR, ORNL-TM-3769 (August 1972).

Ball, S. J., N. E. Clapp, Jr., and J. G. Delene, ${ }^{3}$ Controlled-Trend Paremeter Variation Tests on the OSW Whightsville Beach Three-Stage Flash Evapurator, August 1970, ORNL-TM-3393 (November 1971).

Bertrand, F. E., W. R. Burrus, ${ }^{5}$ N. W. Hill, T. A. Love, ${ }^{6}$ and R. W. Peelle," "A High Resolution Spectrometer System with Particle Identification for 1- through 60-MeV Hydrogen and Helium Particles," Nuc! Instr. Methods 101(3), 475-92(1972).

Booth, R. S., R. B. Perez, ${ }^{6}$ A. R. Buhl, J. C. Robinson, ${ }^{2}$ and E. Carroll, ${ }^{7}$ "Interpretation of 2.0-2.57-MeV Neutron Pulse Propagation in Iron," Trans. Arier. Nucl. Soc. 15(1), 530-31 (June 1972).

Booth, R. S., and S. V. Kaye, ${ }^{8}$ A Preiiminary Systems Anulysis Model of Radioactivity Transfer to Man from Deposition in a Terrestrial Environment, ORNL-TM-3135 (October 1971).

Booth, R. S., J. E. White, ${ }^{9}$ S. K. Penny, ${ }^{9}$ ar + K. J. Yost, 10 "A Comparison of Calculated and Measured Yields of Neutron-Energy-Dependent Capture Gamma Rays from Uranium-238," Nucl. Sci. Eng. 47. s-18 (19\%2).

Borkowski, C. J., Instrumentation and Controls Division Annual Progress Report September 1, 1971 , ORNL-4734 (July 1972).

Borkowski, C. J., and M. K. Kopp, "Proportional Counter Photon Camera," IEEE Trans. Nucl. Sci. NS-19(3), $161-68$ (1972).

Buhl, A. R., N. J. Ackermann, Jr., and J. C. Robinson," "Application of Transport Theory Kinetics to the Interpretation of Experimental Neutron Noise Spectra in Large Fast Reactors," Trans. Amer. Nucl. Soc. 14(2), 857-58 (October 1971).

Buhl, A. R., and R. L. Childs, "The Response of the FFTF Ex-Vessel Detectors to Large $2: 2$ Cf Sources," Trans. Amer. Nucl. Soc. 14(2), 513-15 (October 1971). 
Buhl, A. R.. ‥ J. Ackermann, Jr., R. C. Kryter, and J. C. Rooinson," "Subcriticality Measurements in SEFOR." Trans. Amer. .Vucl. Soc. 15(1). 423-24 (June 1972).

Buhl. A. R., J. C. Rubinson, ${ }^{2}$ and N. I. Ackermann, Jr, "An Interci-:parisori of Techniques for Inferring Subcriticality in Fast Reactors," Irans. Amer. Nucl. Soc. 15(1), 493 - 95 (June 1972).

Bullock. J. B., G. R. Owens." ${ }^{1}$ and W. H. Sides. Jr., Reactor On-Line Com!nuter Control Development at the HFIR, Vol. 2: Program Listings, Summaries, and Logic Diagram:, ORNL-TM-3679 (February 18. 1972).

Burke, O. W. and R. V. ONeill, ${ }^{8}$ A Simple Systems Mudel for DDT and DDE Mfovement in the Human Food Chain, ORNL IBP-71-9 (November 1971).

Burke, O. W., A Hybrid Computer Simulation of the MSBR, ORNL-TM-3767 (May 5, 1972).

Burtis, C. A., ${ }^{2}$ J. C. Mailen, ${ }^{13}$ C. D. Scott, ${ }^{3}$ W. F. Johnson, T. O. Tiffany, 12 and J. B. Overton, ${ }^{13}$ with ccintributions from N. G. Andersen, ${ }^{2}$ J. E. Attrill, ${ }^{14}$ E. L. Collins, C. A. Hahs, ${ }^{15}$ J. M. Jansen, M. T. Kelley,:4 R. A. Mathis, L. H. Thacker, W. A. Walker, ${ }^{16}$ and D. D. Wills, ${ }^{12}$ Gravity Zero (GQ) Analytical Clinical Laboratory System Annual Progress Report for the Period April 1 1971, to March 31, 1972, ORNL-TM-3792.

Burtis, C. A., 12 W. F. Johnson, J. C. Mailen, ${ }^{13}$ and J. E. Attrill, 14 "Automated Sample-Reagent Loader for Use With the GeMSAEC Fast Analyzer," Clin. Chem 18(5), 433 (1972).

Case, F. N., ${ }^{17}$ E. H. Acree, 17 and H. R. Brashear, "A Survey System for Use in Tracing RadionuclideTagged Sediment in the Marine Environment," pp. 603-28 in Nuclear Techniques in Environmental Pollution, IAEA, Vienna, 1971.

Chen, C. H., ${ }^{11}$ T. W. Kerlin, ${ }^{2}$ and D. N. Fry, "Experiences with Binary Periodic Signals for Dynamic Testing at the HFIR," IEEE Trans. Nucl. Sci. NS-19(1), 828-36 (February 1972).

Clay, W. T., Development of a Gamma Ionization Chamber for the Office of Civil Defense, ORNL-TM-3474 (July 30, 1971).

Delene, J. G., ${ }^{3}$ and S. J. Ball, A Digital Computer Code for Simulating Large Multistage Flash Evaporator Desalting Plant Dynamics, OKNL-TM-2933 (September 1971).

De Lorenzo, J. T., "Measurements of the Shieiding Effectiveness of Coaxial and Two-Conductor Cables," Rev. Sci. Instr. 43(1), 161-64 (January 1972).

Codds, H. L., Jr., 18 and J. C. Robinson, 2 "A New Calculational Technique for Space-Energy-AngleDependent Reactor Kinetics," pp. 211-32 in Dynumics of Nuclear Systems (D. L. Hetrick, ed.), University of Arizona Press, Tucson, 1972.

Dodds, H. L., Jr., 18 J. C. Rnbinson, ${ }^{2}$ and A. R. Buhl, "The Formulation and Application of the Transfer-Scattering Matrix Method to Space-, Energy-, and Angular-Dependent Fast Reactor Kinetics," Nucl. Sci. Eng. 47, 262-74 (1972).

Edwards, N. T., ${ }^{8}$ R. I. Van Hook, Jr., ${ }^{8}$ and F. M. Rau, Portable System for Continuous Arilysis of Environmental Carbon Dioxide, ORNL IBP-71-7.

Fry, D. N., and T. W. Kerlin, ${ }^{2}$ Preliminary Coolant Temperature Osci!lation Measurements at the Fuel-Failure Mockup, ORNL-TM-3761 (August 1972).

Fry, D. N., "A Method for Verifying Reactivity Feedback Time Response in Power Reactors," Trans. Amer. Nucl. Soc. 14(2), 792-93 (October 1971).

Glass, F. M., Ionization Chamber Current Quantizer for Radiological Environmental Monitoring Systems, ORNL-TM-3906 (August 1972).

Gwin, R., ${ }^{6}$ E. G. Silver," and R. W. Ingle, "Measurement of Neutron Fission Cross Section for ${ }^{239}$ : $u$ and ${ }^{23} 3 \mathrm{U}$ from $0.02 \mathrm{eV}$ to $200 \mathrm{keV}$," Trans. Amer. Nucl. Soc. 15(1), $481-82$ (June 1972).

Hagen, E. W. (ed.), "Control and Instrumentation," Nucl. Safety 12(5). 496-515 (Septembe:-October 1971): 12(6), 583-90 (November-December 1971); 13(1), 29-36 (January-February 1572); 13(3), 220-24 (May--June 1972); 13(4) 295--300 (July-August 1972). 
Hagen, E. W., "Reactor Availability and Station Reliability for Continuity of Service," Nucl. Safety 12(5). 499 - 515 (September-October 1971).

ildgen E. W.. "The Fourteenth Power Instrumentation Symposium of the Instrument Society of America," Nucl. So fet; 13(1), 29-36 (January-Febnuary 1972).

Herskovitz, M. B., Thermal Cycling Life Tests of Metal Sheathed Thermocouple Assemblies, ORNL-TM3907 (September 1972).

Herskovitz. M. B., Quality Assurance Plan for the Large-Scule Procurement of Temperature Sensors. DRNL-TM-3740 (March 1972).

Katz, Sicusey, 13 and L. H. Thacker, "A New Sensitive Ultraviolet Detection System for Carbohydrates Eluted Dirring Column Chromarography,” J. Chromatog. 64, 24i-52 (1972).

Kryter, R. C. N. I. Ackermann, Ir., and A. R. Buhl, Subcriticality Meaxurements in FTR-3: The Homogeneolis Mockup of the Fast Test Reactor, ORNL-TM-3715 (February 1972).

Macklin, R. L., ${ }^{4}$ N. W. Hill, and B. J. Allen, 19 "Thin ${ }^{6}$ Li(n,a)T Transmission Flow Monitor," Nucl. Instr. Methods 96(4), 509-13 (1971).

Martin, C. D., Jr., The Design and Construction of a Small Computer Real-Time Executive Prostrm for Process Control and Data Acquisition, ORNL-TM-3309 (July 1972).

McDearman, J. R.,2 J. M. Googe," and R. L. Shepard, "A Three-Wire Insulator Shunting Model for High-Temperature Thermocounle Errors," IEEE Trans. IE anci II. IECI-18. 137-44(November 1971).

Millard, J. K., T. V. Blalock, ${ }^{2}$ an W. Hill, “A Broadband Current Preamplifier Configuration for Obtaining High Resolution Energy and Time Information from Nuclear Radiation Detectors," IEEE Trans. Nucl. Soc. NS-1Y(1), 388-95 (Feoruary 1972).

Penland, J. R.,' N. J. Ackermann, Jr, and S. H. Hanauer,' "Space- and Energy-Dependent Reactor Noise Measurements," Trans. A.mer. Nucl. Soc. 14(2), 854-55 (October 1971 ).

Robinson, J. C., 2 anij M. L. Alexander, "Calculation of Reactor Noise Spectra Úsing a Space-Energy Dependent Model: Comparison with Experiment," Trans. Amer. Nucl. Soc. 14(2), 856-57 (October 1971).

Robinson, J. C., ${ }^{2}$ and N. J. Ackermann, Jr., "A Noise Technique for Measuring Reactivity Independent of the Neutron Generation Time," Nucl. Technol. 13, 250-56 (March 1972).

Rosler, H., J. K. Millard, and N. W. Hill, "Fast Timing from a Fission Ionization Chamber," Nusl. Instr. Methods 99(3), 477-86(1972).

Roux, D. P., "Startup Neutron Detectors for LMFBR Application," Trans. Amer. Nucl. Soc. 14(2), 497 (October 1971).

Ro"ix, D. P., and J. C. Robinson, ${ }^{2}$ "Formulation of the Gamma Pileup Effect in Fission Counters," Trans. Amer. Nucl. Soc. 15(1), 423 (June 1972).

Roux, D. P., and A. R. Buhl, "Effect of Gamma Radiation on LMFBR Subcriticality Measurements Using Noise Analysis," Nucl. Technol. 12, 137-40 (September 1971).

Rubel, P., Reliability Engineering Methods in Reactor Safety Technology, ORNL CF-72-3-3y (June 1972).

Rubel, P., “Reliability Methods Applied to Reactor Safety: Trends and Progress," IEEE Trans. Nucl. Sci. NS-19́1), 883-87 (February 1972).

Sides, W. H., Ji., J. W. Allen, ${ }^{2}$ and J. B. Bullock, "Computer Surveillance of Reactivity During Startup at the HFIR," Trans. Amer. Nucl. Soc. 15(1), 424-25 (June 1972).

Weston, L. W., ${ }^{6}$ and J. H. Todd, "Neutron Fission and Absorption Cross-Section ideasurements for ${ }^{239} \mathrm{Pu}$ and 24 ' Pu," Trans. Amser. Nucl. Soc. 15(1), 480-81 (June 1972).
1. Babcock and Wilcox.
2. University of Tennessee.
3. Reactor Division. 


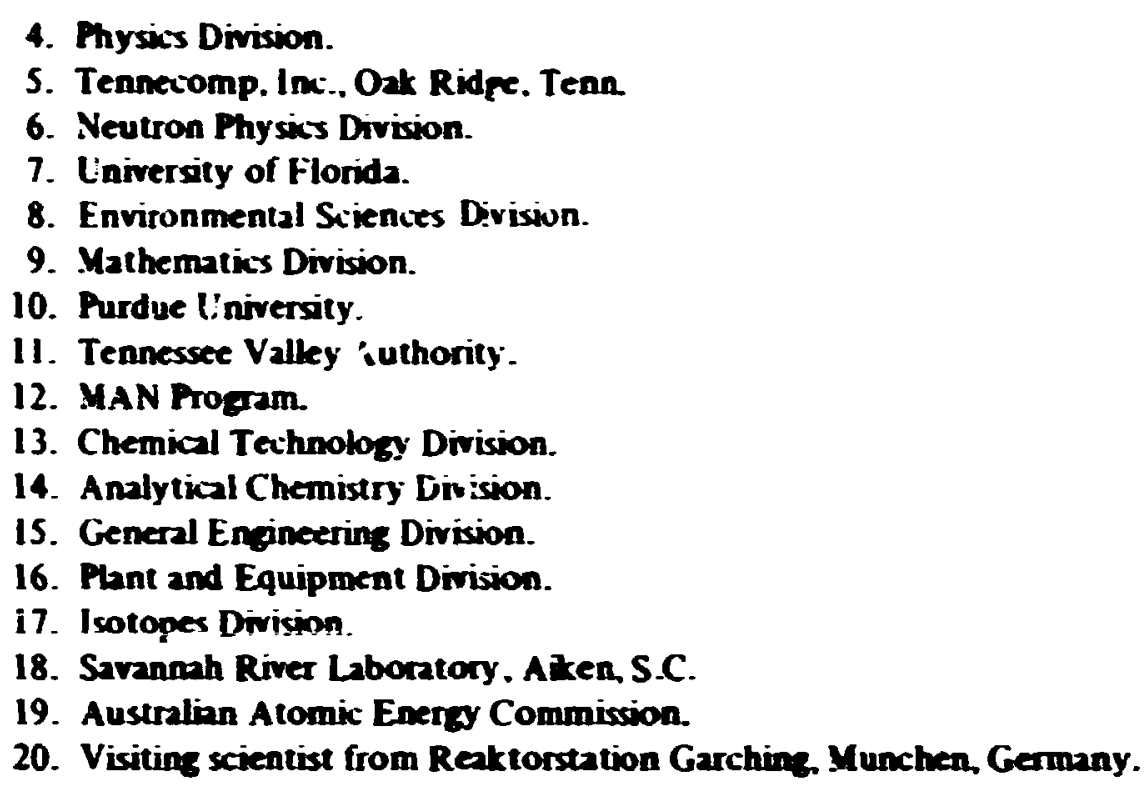

\section{Papers Presented at Professional Meetings}

Some of the papers listed below were prepared jointly with members of other divisions and with consultants and other nonemployees. Their affiliations are footnoted.

$197 !$ Winter Meeting American Nuclear Society, Miami Beach, Florida, Oc'nber 17-21, 1971

Ackermann, N. J., Jr., J. R. Penland,' and S. H. Hanauei," "A Space- and Energy- Dependent, Four-Nodal Point Neutron Fluctuation Theory."

Buhl, A. R., N. J. Ackermann, Jr., and J. C. Robinson, 2 "Application of Transport Theory Kinetics to the Interpretation of Experimental Neutron Noise Spectra in Large Fast Reactors."

Buhl, A. R., and R. L. Childs, "The Response of the FFTF Ex-Vessel Detectors to Large ${ }^{252} \mathrm{Cf}$ Sources."

Fry, D. N., "A Method for Verifying Reactivity Feedback Time Response in Power Reactors."

Pen!and, J. R.,' N. J. Ackermann, Jr., and S. H. Hanauer, 'Space- and Energy- Dependent Reactor Noise Measurements."

Robinson, J. C., ${ }^{2}$ and M. L. Alexander," "Calculation of Reactor Noise Spectra Using a Space-Energy Dependent Model: Comparison with Experiment."

Roux, D. P., "Startup Neutron Detectors for LMFBR Applications."

18th Nuclear Science Symposium and Third Nuclenr Power Symposium, San Francisco. California, November 3-5, 1971

Chen, C. H., T.W. Kerlin, ${ }^{2}$ and D. N. Fry, "Experiences with Binary Periodic Signals for Dynamic Testing at the HFIR."

Millard, J. K., T. V. Blalock, ${ }^{2}$ and N. W. Hill, " $\Lambda$ Broadband Current Preamplifier Configuration for Obtaining High Resolution Energy and Time Information from Nuclear Radiation Detectors."

Rubel, P., “Reliability Methods Applied to Reactor Safety: Trends and Progress."

1972 Thirteenth Scintillation and Semiconductor Counter Symposium, Washington, D.C., March I-3, 1972

Borkowski, C. J., and M. K. Kopp, “Proportional Counter Photon Camera." 
1972 Annual Meeting American Nuclear Suciety. Las Vezes. Neneda. June 18-22. 1972

Ackermann. N. J., Jr., D. P. Roux, w. T. Clay, and G. C. Guerrant, “A Low Level Neutron Flux Monitoring System for LMFBR's."

Booth, R. S., R. B. Perez,5 A. R. Buhl, J. C. Robinson.2 and E. Carroll.6 "Interpretation of 2.0-257 MeV Neutrsn Pulse Propagation in Iron."

Buhl, A. R., N. J. Ackermann, Jr., R. C. Kryter, and J. C. Robinson, ${ }^{2}$ "Subcriticality Measurements in SEFOR"

Buhl, A. R., J. C. Robinson, ${ }^{2}$ and N. J. Ackermann, Jr, "An Intercomparison of Techniques for Inferring Subcriticality in Fast Reactors."

Gwin, R.,5 E. G. Silyer, 5 and R. W. Inde, "Measurement of Neutron Fission Cross Section for ${ }^{239}$ Pu 2ad 235 ; ; from $0.02 \mathrm{eV}$ to $200 \mathrm{keV}$."

Roux, D. P., and J. C. Robinson, "Fonnulation of the Gamma Pileup Effect in Fission Counters."

Sides, W. H., Jr., J. W. Allen, ${ }^{2}$ and J. B. Bullock, 'Computer Surveillance of Reactivity During Startur: at the HFIR."

Weston, L. W..5 and J. H. Todd, "Neutron Fission and Absorption Cross-Section Measurements for ${ }^{239} \mathrm{Pu}$ and $241 \mathrm{Pu} . "$

24th National Meeting of Amerioun Association of Clinical Chemists, Cincinnati, Orio, August 20-25, 1972

Tiffany, T. O., ${ }^{7}$ L. H. Thacker, C. A. Burtis, ${ }^{7}$ and C. D. Scott, "A Multicuvet Fast Fluorometric Analyzer Based on the GeMSAEC Principle.

1. Babioct and Wiloox.

2. University of Tennesser.

3. Mathematics Division.

4. Tennesuee Valley Authority.

5. Neutron Physics Division.

6. University of Florida.

7. MAN Program.

8. Chemical I, hnology Division.

\section{Patents}

Casimer J. Borkowski and Manfred K. Kopp, "Two-Dimensional Position-Sensitive Radiation Detector," U.S. Pat. 3,603,797(September 7, 1971).

Casimer J. Borkowski, "Differential Pressure Nuclear Radiation Flux Detector," U.S. Pat. 3,631,254 (November 16, 1971).

William R. Miller and Carl M. Smith, Jr., "Self-Adaptive Welding Torch Controller," US. Pat. 3,646,309(February 29, 1972).

James M. Jansen, Jr., “Computer Interface," U.S. Pat. 3,656,1 16(April 11, 1972). 
INSTRUMENTATION AND

C. '. BORKOWSKI, DIF

R. A. DANDL. “ ASSOCIAT

L. C. OAREES" ASSOCIATE

SPECIAL ASSGMENTS

C. S. Lisser

G. S. SADOWSKI

CONTROLS DEPARTMENT

L. C. OAKES

Arue rsis

R. S. STONE

DEVELOFNENT

D. P. ROUX

REACTOR PROJECTS

S. J. DITTO

K. W. WEST

MECHANICAL DEVELOPMENT AND ENGINEERING GRAPHICS

H. J. STRIPLING

\section{BASIC INSTRUMENTATION}

C. J. BORKOWSKI"
CIRCUIT DE

H. N. W

COMPUTER

TECH

J. w.

SPECIAL E SER

J. L. LC

- dual c. icity

- ON LOAN to thermonuclear division

- Quality ASSURANCE COORDINATOR

- TECHNICAL REPORTS EDITOG, RADIATION CONTROL OFFICER, AND DIVISION SAFETY OFFICER 


\section{BLANK PAGE}


